\title{
HYDROGEOLOGIC FRAMEWORK, WATER LEVELS, AND TRICHLOROETHYLENE CONTAMINATION, NAVAL AIR WARFARE CENTER, WEST TRENTON, NEW JERSEY, 1993-97
}

Water-Resources Investigations Report 98-4167

Prepared in cooperation with the U.S. NAVY

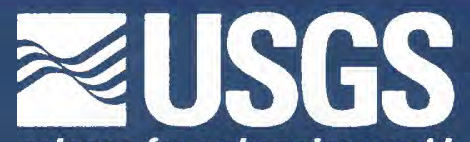


HYDROGEOLOGIC FRAMEWORK, WATER LEVELS, AND TRICHLOROETHYLENE CONTAMINATION,

NAVAL AIR WARFARE CENTER, WEST TRENTON, NEW JERSEY, 1993-97

By Pierre J. Lacombe

U.S. Geological Survey

Water-Resources Investigations Report 98-4167

Prepared in cooperation with the

U.S. NAVY

West Trenton, New Jersey

2000

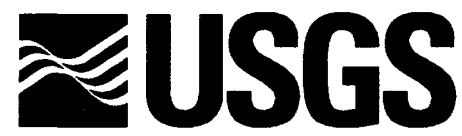

science for a changing world 


\section{U.S. DEPARTMENT OF THE INTERIOR \\ BRUCE BABBIT, Secretary}

\section{U.S. GEOLOGICAL SURVEY}

Charles G. Groat, Director

The use of firm, trade, and brand names in this report is for identification purposes only and does not constitute endorsement by the U.S. Geological Survey.

For additional information write to:

District Chief

U.S Geological Survey

Mountain View Office Park

810 Bear Tavern Road, Suite 206

West Trenton, NJ 08628
Copies of this report can be purchased from:

U.S. Geological Survey

Branch of Information Services

Box 25286

Denver, CO 80225-0286 


\section{CONTENTS}

P sge

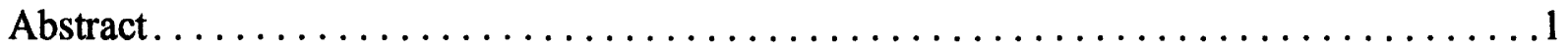

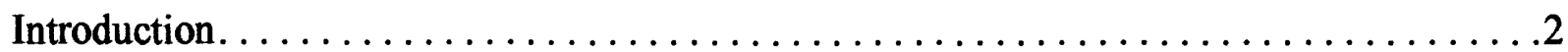

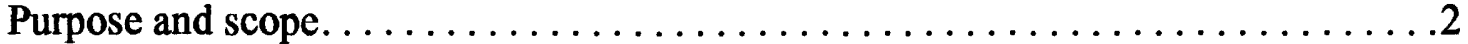

Previous investigations . . . . . . . . . . . . . . . . . . . . .

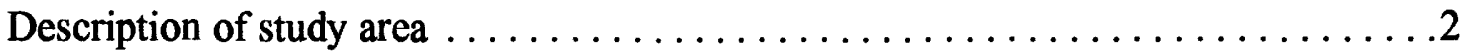

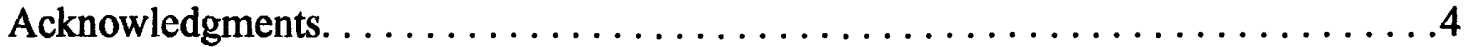

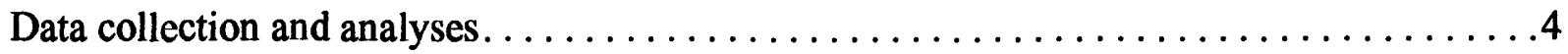

Hydrogeologic framework development $\ldots \ldots \ldots \ldots \ldots \ldots \ldots \ldots \ldots \ldots \ldots$

Water-level analyses . . . . . . . . . . . . . . . . . . . . . . 6

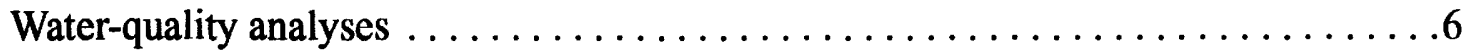

Water-level and water-quality contouring methods $\ldots \ldots \ldots \ldots \ldots \ldots \ldots \ldots$

Hydrogeologic framework . . . . . . . . . . . . . . . . . . . . . 11

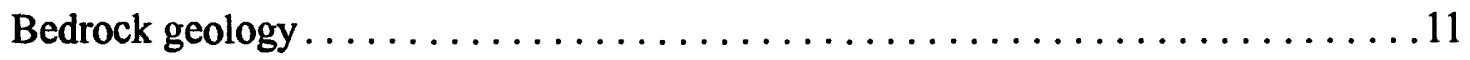

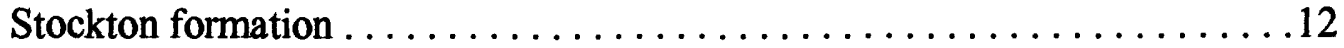

Lockatong formation. . . . . . . . . . . . . . . . . . 13

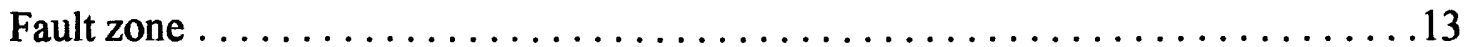

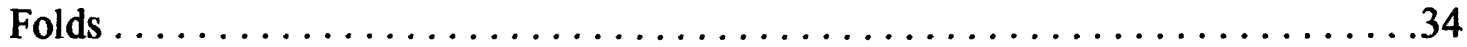

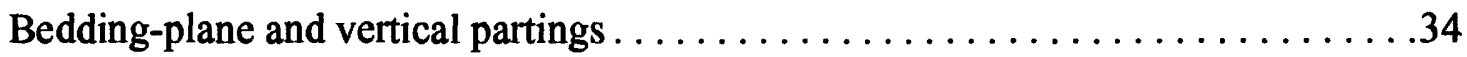

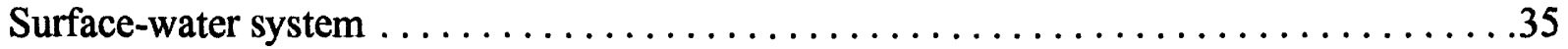

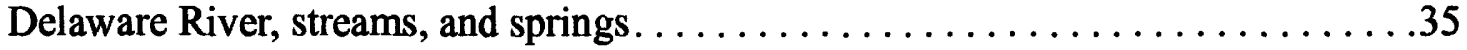

West Branch of Gold Run . . . . . . . . . . . . . . . . . . . . 36

Ground-water levels . . . . . . . . . . . . . . . . . . . . . . . . . . . . .41

Static water levels . . . . . . . . . . . . . . . . . . . . . . . .

Drawdown water levels during aquifer tests. . . . . . . . . . . . . . . 54

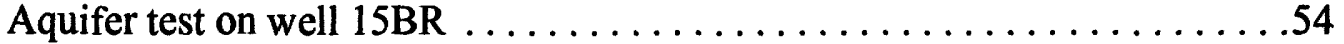

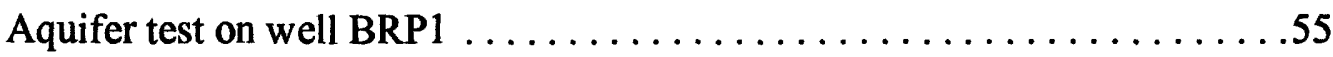

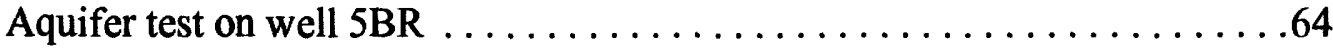

Summary of aquifer test data analyzed for drawdown $\ldots \ldots \ldots \ldots \ldots 76$

Stressed water levels during operation of the recovery well $\ldots \ldots \ldots \ldots \ldots \ldots$

Water quality

Trichloroethylene . . . . . . . . . . . . . . . . . . . . . . . . . . .89

Site 3: Lagoon and sludge disposal area . . . . . . . . . . . . 108

Area between Site 3 and Site $1 \ldots \ldots \ldots \ldots \ldots \ldots \ldots . \ldots \ldots$

Site 1: Brine-handling area . . . . . . . . . . . . . . . . . . . 109

Scenario 1: DNAPL TCE at depths greater than 250 feet . . . . . . 109

Scenario 2: No DNAPL TCE at depths greater than 100 feet . . . . 111

Area west of Site $1 \ldots \ldots \ldots \ldots \ldots \ldots \ldots \ldots \ldots \ldots$

cis-1,2-Dichloroethylene. . . . . . . . . . . . . . . . . . . 111 


\section{CONTENTS--Continued}

Fige

Site 3: Lagoon and sludge disposal area . . . . . . . . . . . . . 111

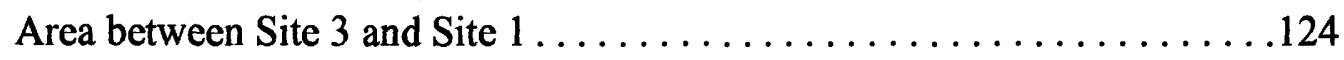

Site 1: Brine-handling area . . . . . . . . . . . . . . . . . . 124

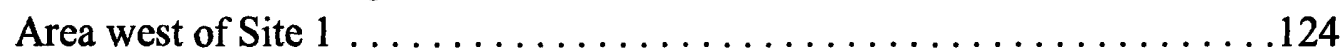

Vinyl chloride . . . . . . . . . . . . . . . . . . . . . . . . . . . . . 124

Site 3: Lagoon and sludge disposal area . . . . . . . . . . . . . . 137

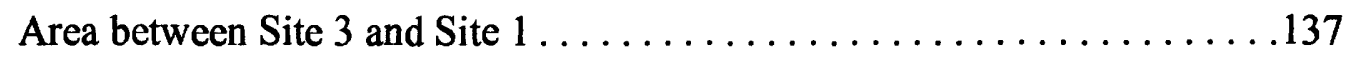

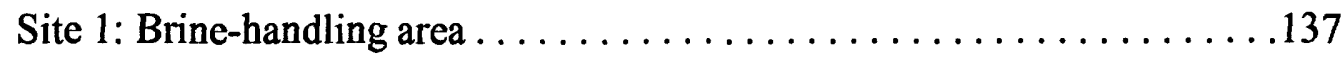

Summary and conclusion . . . . . . . . . . . . . . . . . . . . . . 137

References cited . . . . . . . . . . . . . . . . . . . . . . . . . . . . . 139

\section{ILLUSTRATIONS}

Figure 1. Digital orthophoto showing the location of the study area, Naval Air Warfare Center, West Trenton, N.J. . . . . . . . . . . . . . . . . . 3

2. Map of study area showing location of contamination Sites 1 and 3 and location of bedrock wells, Naval Air Warfare Center ............. 5

3a. Map and section $W-W$ ' showing a hypothetical small valley, strike and dip $c^{f}$ bedrock, stream, and wells. . . . . . . . . . . . . . . 8

3b. Map and section $\mathrm{W}-\mathrm{W}^{\prime}$ showing static potentiometric surface $\ldots \ldots \ldots \ldots 8$

4. Diagram of a bedding unit in a hypothetical bedrock aquifer that shows finescale water-bearing zones and semi-confining zones $\ldots \ldots \ldots \ldots \ldots 9$

5a. Map and section X-X' showing a hypothetical small valley, strike and dip of bedrock, stream, streamflow direction, fault, and wells $\ldots \ldots \ldots \ldots \ldots 10$

5b. Map and section X-X' showing static potentiometric surface on one side of the fault and ground-water-flow direction along the fault .......... 10

6. Map showing the geology in the area of the Naval Air Warfare Center . . . . 14

7a. Bedding units of the Stockton and Lockatong Formations south of the fault, Naval Air Warfare Center . . . . . . . . . . . . . . . . . . . . 16

7b. Bedding units of the Lockatong Formation north of the fault, Naval Air Warfare Center . . . . . . . . . . . . . . . . . . . . 17

8. Map showing the bedding units and the fault trace at an altitude of $+150 \mathrm{fee}^{+}$ (approximately at land surface), Naval Air Warfare Center ......... 18 


\section{ILLUSTRATIONS--Continued}

Prge

Figure 9. Map showing the bedding units and the fault trace at an altitude of $+50 \mathrm{ft}$ (approximately 100 feet below land surface), Naval Air Warfare Center. . 19

10 to 18 . Sections showing natural gamma-ray logs, dip angle from rock cores, geophysical bedding units, fault zone, and well screen placement for shallow and deep wells

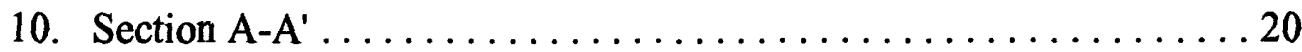

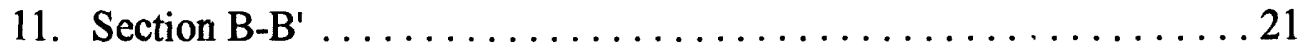

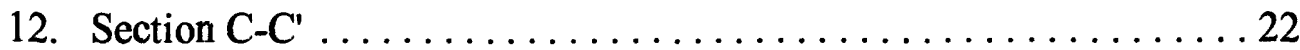

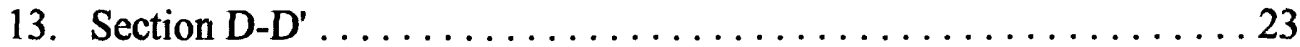

14. Section E-E' ................................ 24

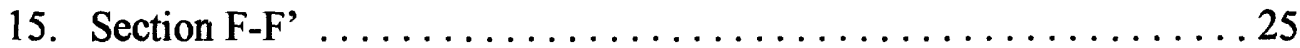

16. Section G-G' .............................. 26

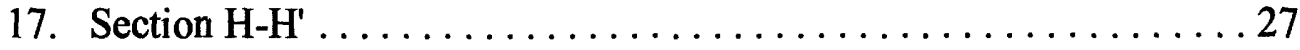

18. Section I-I' ............................. 28

19. Simplified block diagram of the study area showing diagramatic bedding units of the Stockton Formation, Lockatong Formation and the trust fault

20. Photograph of rock core from well $42 \mathrm{BR}$ at 68 feet below land surface showing steeply dipping beds on either side of brecciated and cemented fault zone .

21. Photograph of rock core from well 42BR at 111 feet below land surface showing steeply dipping beds and a shallow dipping fault ......... 30

22. Photograph of rock core from well 42BR at 127 feet below land surface showing steeply dipping beds and brecciated in the fault zone........ 31

23. Photograph of rock core from well 17BR at 55 feet below land surface showing gently dipping beds and steeply dipping fault............ 31

24. Photograph of rock core from well $51 \mathrm{BR}$ at 95 feet below land surface

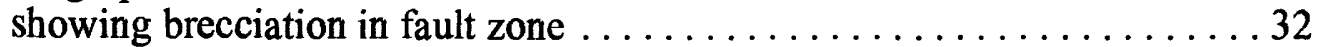

25. Photograph of rock cores from well $42 \mathrm{BR}$ showing shallow dipping bedrocl and well 43BR showing steeply dipping bedrock $\ldots \ldots \ldots \ldots \ldots \ldots, 32$

26. Map from 1913 showing the original channels of Gold Run .......... 37 


\section{ILLUSTRATIONS--Continued}

Fage

Figure 27a. Map and section showing the construction of the culvert underneath the south side of Parkway Avenue that acts as the channel for the West Branch of Gold Run and location of the culvert under the north side of Parkway Avenue which carries stormwater from Naval Air Warfare Center.

27b. Map showing the construction of the culvert underneath the south side of Parkway Avenue that acts as the channel for the West Branch of Gold Run and location of the culvert under the north side of Parkway Avenue that carries stormwater from Naval Air Warfare Center ........ 39

27c. Map showing the three exit culverts that discharge water from (a) GM parking lots, (b) West Branch of Gold Run, Parkway Avenue, and Naval Air Warfare Center, and (c) East Branch of Gold Run ............. 39

28. Map showing the static potentiometric surface at an altitude of +150 feet (approximately land surface), December 4, 1995, Naval Air Warfare Center.

29. Map showing the static potentiometric surface at an altitude of +50 feet (approximately 100 feet below land surface), December 4, 1995, Naval Air Warfare Center ............................ 44

30 to 38 . Sections showing static water-level altitudes measured in bedrock wells, December 4, 1995

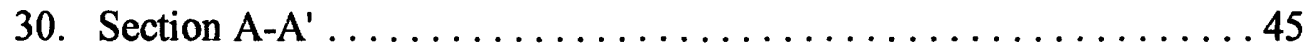

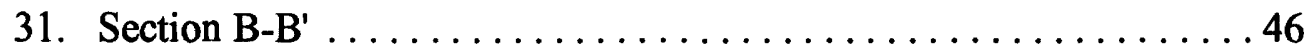

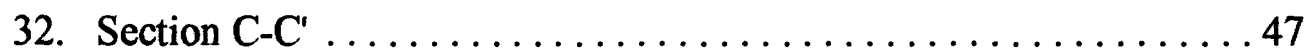

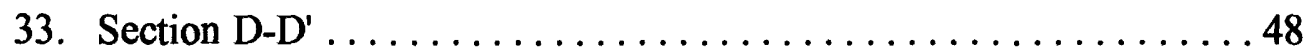

34. Section E-E'............................... 49

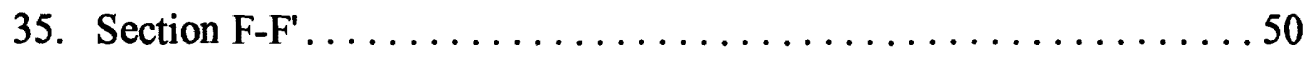

36. Section G-G' $\ldots \ldots \ldots \ldots \ldots \ldots \ldots \ldots \ldots \ldots \ldots \ldots \ldots \ldots \ldots \ldots \ldots \ldots \ldots \ldots \ldots$

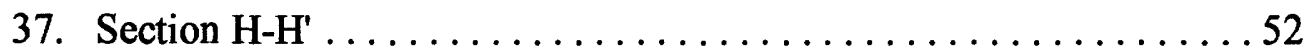

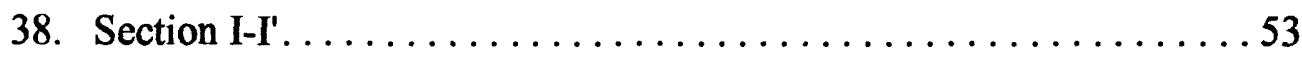

39. Map showing drawdown during the aquifer test with well 15BR pumping, shown at an altitude of $+150 \mathrm{ft}$, (approximately land surface), Naval Air Warfare Center . . . . . . . . . . . . . . . . . . . 56 


\section{ILLUSTRATIONS--Continued}

Page

Figure 40. Map showing drawdown during the aquifer test with well 15BR pumping, shown at an altitude of $+50 \mathrm{ft}$, (approximately 100 feet below land surface), Naval Air Warfare Center.................... 57

41. Map showing drawdown in bedding unit L-19 during the aquifer test with well 15BR pumping, Naval Air Warfare Center ............... 58

42 to 46 . Water-level drawdowns measured in wells along sections during the aquifer test while pumping $15 \mathrm{BR}$

42. Section E-E'.................................. 59

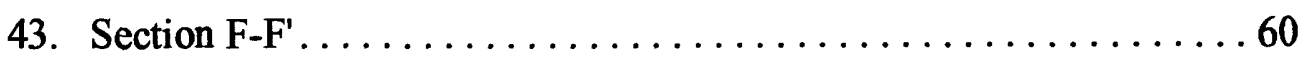

44. Section G-G' ............................. 61

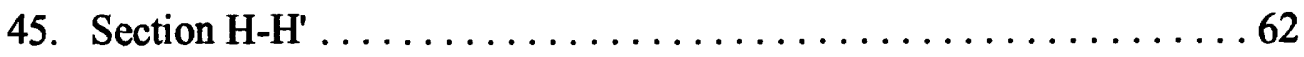

46. Section I-I' . . . . . . . . . . . . . . . . . . . 63

47. Map showing drawdown during the aquifer test with well BRP1 pumping, shown at an altitude of $+150 \mathrm{ft}$, (approximately land surface), Naval Air Warfare Center . . . . . . . . . . . . . . . . . . . . 65

48. Map showing drawdown during the aquifer test with well BRP1 pumping, shown at an altitude of $+50 \mathrm{ft}$, (approximately 100 feet below land surface), Naval Air Warfare Center.

49 to 54. Water-level drawdowns measured in wells along sections during the aquifer test while pumping well BRP1

49. Section E-E'............................... 67

50. Section F-F' $\ldots \ldots \ldots \ldots \ldots \ldots \ldots \ldots \ldots \ldots \ldots \ldots$

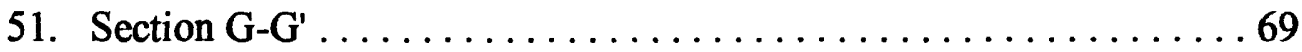

52. Map showing drawdown during the aquifer test with well 5BR pumping, shown at an altitude of $+150 \mathrm{ft}$, (approximately land surface), Naval Air Warfare Center.

53. Map showing drawdown during the aquifer test with well 5BR pumping, shown at an altitude of $+50 \mathrm{ft}$ (approximately 100 feet below land surface), Naval Air Warfare Center

54. Map showing drawdown in bedding units L-15 and L-16 during the aquifer test with well 5BR pumping, Naval Air Warfare Center,

55 to 57. Water-level drawdowns measured in wells along sections during the aquifer test while pumping 5BR 


\section{ILLUSTRATIONS--Continued}

Fige

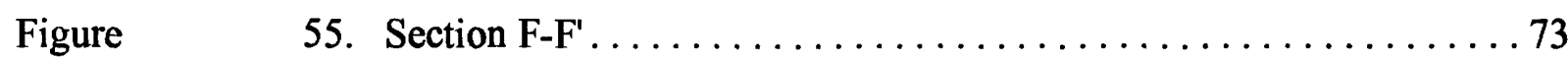

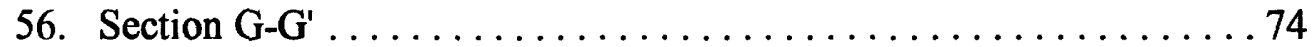

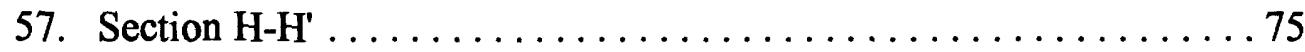

58. Map showing the stressed potentiometric surface in August 1997

shown at an altitude of +150 feet (approximately land surface),

Naval Air Warfare Center . . . . . . . . . . . . . . . . . . . . 77

59. Map showing the stressed potentiometric surface in August 1997

shown at an altitude of +50 feet (approximately 100 feet below land

surface), Naval Air Warfare Center . . . . . . . . . . . . . . 78

60 to 68 . Stressed water-level altitudes measured in wells along sections during operation of the recovery well 15BR, August 25-27, 1997

60. Section A-A' . . . . . . . . . . . . . . . . . . . . . 79

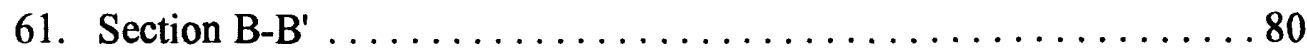

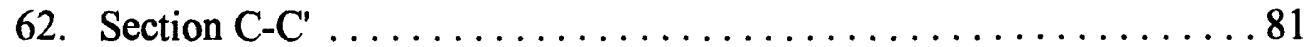

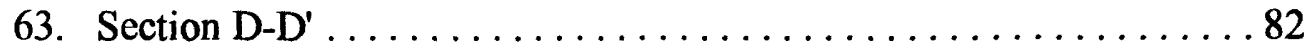

64. Section E-E'.............................. 83

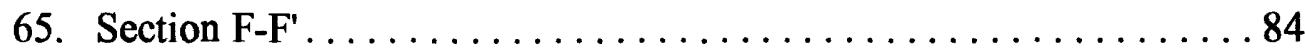

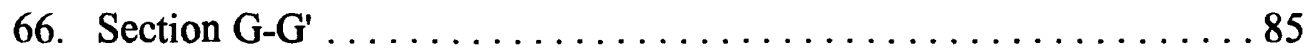

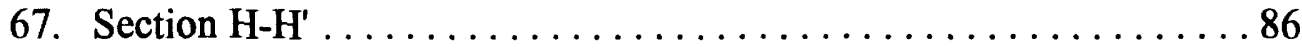

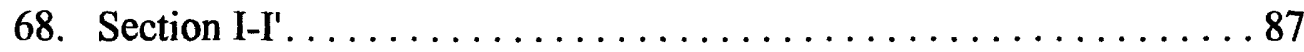

69. Map showing TCE concentrations in water samples from bedrock and shallow wells, June 1997, and contours for top of bedrock (an altitude of $+150 \mathrm{ft}$ and approximately land surface), scenario 1 and 2, Naval Air Warfare Center. .............................. 90

70. Map showing TCE concentrations in water samples from bedrock and shallow wells, June 1997, and contours for an altitude of $+50 \mathrm{ft}$ (about $100 \mathrm{ft}$ below land surface), scenario 1 and 2, Naval Air Warfare Center................................... 91

71a. Map showing TCE concentrations in water samples from bedrock wells, June 1997, and contours for an altitude of - $50 \mathrm{ft}$ (about $200 \mathrm{ft}$ below land surface) scenario 1, Naval Air Warfare Center 


\section{ILLUSTRATIONS--Continued}

Prge

Figure 71b. Map showing TCE concentrations in water samples from bedrock wells, June 1997, and contours for an altitude of - $50 \mathrm{ft}$ (about 200 feet below land surface), scenario 2, Naval Air Warfare Center. .

72 to 80 . Sections showing TCE concentrations in water samples from bedrock and overburden wells, June 1997

72. Section A-A' . . . . . . . . . . . . . . . . . . . . . . . . . 94

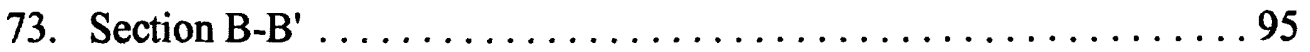

74. Section C-C' .............................. 96

75. Section D-D' ............................. 97

76a. Section E-E', Scenario $1 \ldots \ldots \ldots \ldots \ldots \ldots \ldots \ldots$

76b. Section E-E', Scenario $2 \ldots \ldots \ldots \ldots \ldots \ldots \ldots \ldots \ldots$

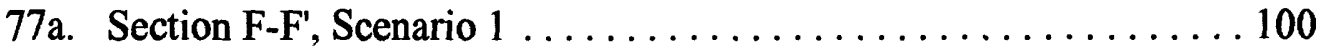

77b. Section F-F', Scenario $2 \ldots \ldots \ldots \ldots \ldots \ldots \ldots \ldots \ldots \ldots$

78a. Section G-G', Scenario $1 \ldots \ldots \ldots \ldots \ldots \ldots \ldots \ldots \ldots \ldots$

78b. Section G-G', Scenario $2 \ldots \ldots \ldots \ldots \ldots \ldots \ldots \ldots \ldots \ldots$

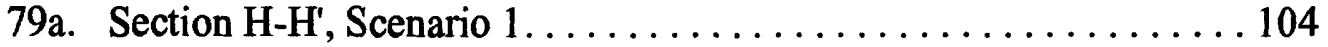

79b. Section H-H', Scenario 2 . . . . . . . . . . . . . . . . . 105

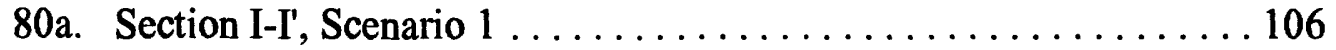

80b. Section I-I', Scenario 2 . . . . . . . . . . . . . . . . . . . . . . . 107

81. Map showing cis-DCE concentrations in water samples from bedrock and shallow wells, June 1997, and contours for top of bedrock (an altitude of $+150 \mathrm{ft}$ and approximately land surface), Naval Air Warfare Center. . . . 112

82. Map showing cis-DCE concentrations in water samples from bedrock and shallow wells, June 1997, and contours for an altitude of +50 feet (about 100 feet below land surface), Naval Air Warfare Center .

83. Map showing cis-DCE concentrations in water samples from bedrock wells, June 1997, and contours for an altitude of -50 feet (about 200 feet below land surface), Naval Air Warfare Center .......... 114

84 to 92 . Sections showing cis-DCE concentrations in water samples from bedrock and overburden wells, June 1997

84. Section A-A' 


\section{ILLUSTRATIONS--Continued}

F $>$ ge

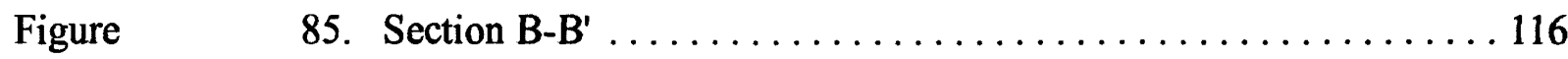

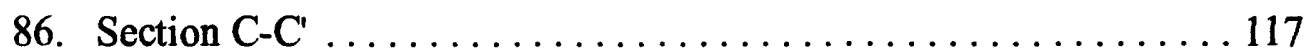

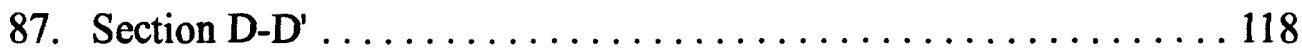

88. Section E-E'................................ 119

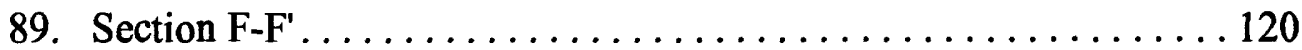

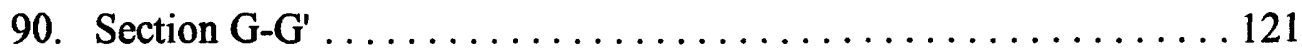

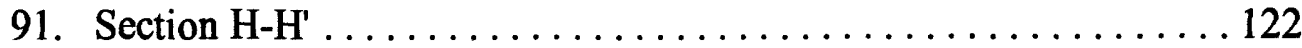

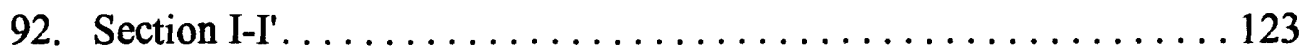

93. Map showing VC concentrations in water samples from bedrock and shallow wells, June 1997, and contours for top of bedrock (an altitude of +150 feet and approximately land surface) Naval Air Warfare Center........ 125

94. Map showing VC concentrations in water samples from bedrock and shallow wells, June 1997, and contours for an altitude of +50 feet (approximately 100 feet below land surface), Naval Air Warfare Center. . 126

95. Map showing VC concentrations in water samples from bedrock wells, June 1997, and contours for an altitude of - 50 feet (about 200 feet below land surface), Naval Air Warfare Center

96 to 104 . Sections showing VC concentrations in water samples from bedrock and overburden wells, June 1997

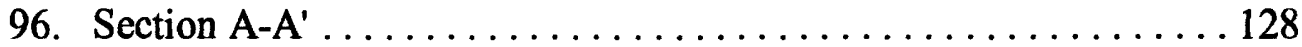

97. Section B-B' . . . . . . . . . . . . . . . . . . . . . . . 129

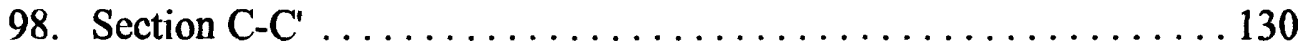

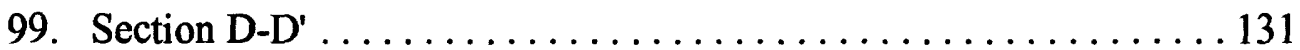

100. Section E-E' .............................. 132

101. Section F-F' . . . . . . . . . . . . . . . . . . . . . . . .

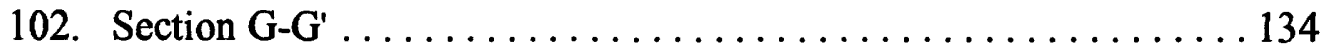

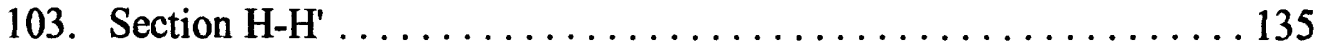

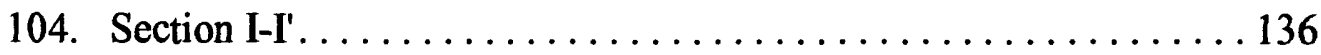




\section{TABLES}

Page

Table 1. Bedding units based on natural gamma-ray logs, drillers logs, and core logs. 15

2. Individual and total discharge from three culverts at the exit of the Gold Run tributaries from under Parkway Avenue $\ldots \ldots \ldots \ldots \ldots \ldots . . \ldots 2$

3. Precipitation at stations at Trenton State College (College of New Jersey) and Washington Crossing State Park during the day of stream gaging

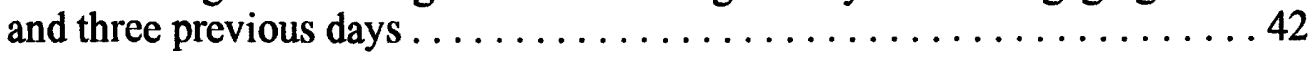




\section{CONVERSION FACTORS, VERTICAL DATUM, AND ABBREVIATED WATER-QUALITY UNITS}

Multiply

inch (in)

inch (in)

foot (ft)

mile (mi)
By

Length

2.54

25.4

0.3048

1.609

Area acre

square mile $\left(\mathrm{mi}^{2}\right)$

square mile

4047

2.59

640

Volume

3.785

7.48

gallon (gal) cubic foot $\left(\mathrm{ft}^{3}\right)$

.02832

Flow

cubic feet per second $\left(\mathrm{ft}^{3} / \mathrm{s}\right)$

cubic feet per second $\left(\mathrm{ft}^{3} / \mathrm{s}\right)$

gallons per minute (gal/min)
449

.02832

0.06309
To obtain

centimeter

millimeter

meter

kilometer

square meter

square kilometer

acre liter

cubic foot

cubic meter

Altitude In this report, "altitude" refers to distance above or below the National Geodetic Vertical Datum of 1929 (NVGD of 1929. Its use is not affected by whether the distance is at vve of below land surface.

Sea level: In this report, "sea level" refers to the National Geodetic Vertical Datum of $192 \Omega$

(NGVD of 1929) - a geodetic datum derived from a general adjustment of the first-order level nets of both the United States and Canada, formerly called Sea Level Datum of 1929.

Concentrations of chemical constituents in water are given either in milligrams per liter $(\mathrm{mg} / \mathrm{L})$ or micrograms per liter $(\mathrm{mg} / \mathrm{L})$. 


\title{
HYDROGEOLOGIC FRAMEWORK, WATER LEVELS, AND TRICHLOROETHYLENE CONTAMINATION, NAVAL AIR WARFARE CENTER, WEST TRENTON, NEW JERSEY, 1993-97
}

\author{
By Pierre J. Lacombe
}

\begin{abstract}
Geophysical, drillers, and geologist logs from 48 bedrock wells at the Naval Air Warfare Center (NAWC) in West Trenton, N.J., were examined and interpreted to prepare structure maps and sections of the hydrogeologic framework. The maps and sections show the geometry of the Stockton aquifer with 5 bedding units and Lockatong aquifer with 14 bedding units. Each bedding unit consists of water-bearing zones and semi-confining zones. An east/west-trending fault crosses the southern part of NAWC and acts as a confining unit.
\end{abstract}

A 1913 topographic map shows the West Branch of Gold Run flowed along Parkway Avenue from the west side to the east side of NAWC. A 1942 roadway construction map shows that the stream was confined in a culvert under Parkway Avenue. The stream/culvert is still active as a ground-water/surface-water discharge area.

Static water levels from the 48 wells indicated that the ground-water-flow direction in the Lockatong aquifer is along bedding strike and to the west with discharge into the West Branch of Gold Run. Drawdown water levels during three aquifer tests indicated that the Lockatong aquifer is anisotropic. The water-bearing zones in the aquifer are isotropic or nearly so in the plane of the zone. Stressed water levels for 48 bedrock wells show that the recovery well causes a local anisotropic cone of depression, which probably does not capture the whole TCE contamination plume.

Analysis of water-quality data from th $\odot 48$ wells indicate the extent of plumes of tricl loroethylene (TCE) and its degradation prod icts, cis-1,2-dichloroethylene (cis-DCE) and vinyl chloride (VC). The TCE plume emanating from a waste lagoon and sludge-disposal area (Site 3 ) is moving along strike to the west along the north side of the fault. The TCE plume emanating from a brine-handing arsa (Site 1) is interpreted for two scenarios. Scenario 1 assumes that dense non-aqueous phase liquid (DNAPL) TCE has sunk into the Lockatong aquifer to a depth of more than 200 $\mathrm{ft}$. Scenario 2 assumes that the DNAPL TCE has dissolved by a depth of $100 \mathrm{ft}$ below land surface. cis-DCE and VC concentrations indicate that degradation of TCE is occurring at depths of 0 to $100 \mathrm{ft}$ below land surface but that degradation is not occurring to a significant extent at greater depths. The cis-DCE and VC plumes appear to be moving west of Site 1 as a result of ground-water flow. Centers of the cis-DCE and VC plumes are 100 and $200 \mathrm{ft}$, respectively, west of the center of the TCE plume. 


\section{INTRODUCTION}

The U.S. Naval Air Warfare Center (NAWC) in West Trenton, N.J., was a jet engine testing facility for military aircraft from the mid-1950's until the late 1990's. As a result of the activities at the facility, trichloroethylene (TCE) and other chemicals have leaked onto the ground surface. TCE and other compounds have been detected in ground water at two sites at the NAWC (figs. 1 and 2). During a remedial investigation, high concentrations of TCE, as well as its degradation products, cis 1,2-dichloroethylene (cis-DCE) and vinyl chloride (VC), and other contaminants were detected in ground water at the NAWC (International Technology Corp., 1994). Reported concentrations of TCE dissolved in ground water in a brine-handling area (Site 1) during 1992-93 ranged from less than $10 \mathrm{mg} / \mathrm{L}$ to more than $20,000 \mathrm{mg} / \mathrm{L}$. The latter concentrations strongly indicate the presence of non-aqueous phase TCE. At the same time, reported concentrations of TCE dissolved in ground water in a wastewater lagoon and sludge disposal-area (Site 3) ranged from less than the detection limit of 10 $\mathrm{mg} / \mathrm{L}$ to $320 \mathrm{mg} / \mathrm{L}$ (International Technology Corp., 1994).

During 1993-97 the USGS, in cooperation with the U.S. Navy, conducted several studies to determine the hydrogeologic framework of the site, measure and map ground-water levels, collect samples for water-quality analysis, and map ground-water contamination plumes at the NAWC. The USGS also provided technical oversight and assistance to the U.S. Navy.

During the same time, the US. Navy contracted EA Engineering, Science, and Technology Inc. to provide drilling services, collect water- quality samples for analysis, and measure water levels.

\section{Purpose and Scope}

This report presents an integrated irterpretation of the hydrogeologic data collected at Sites 1 and 3 at the U.S. Naval Air War'are Center (NAWC). This report includes maps and sections that describe and show the hydrogeologic framework of the bedrock, the distribution of ground-water levels, and the extent and distribution of contamination by TCE, cisDCE, and VC. The USGS collected geo 'nysical logs from 48 bedrock wells at the NAWC. Geologists' logs, core logs, water-level data, drawdown data from aquifer tests, and v'aterquality data are from published remedial investigation reports (International Technology Corp., 1994) and site interim action reports (EA Engineering, Science, and Technology Inc., 1995, 1996a, 1996b, 1996c, and 19?7.

\section{Previous Investigations}

International Technology Corporation (1994) conducted a remedial investigation of the NAWC. The final report is in 6 volumes, and it covers the hydrogeologic framework, ground-water levels, ground-water quality, and surface-water quality. EA Engineering, Science, and Technology, Inc. (1995, February 1996, June 1996, July 1996, and August 1997) continued the framework, water-level, and water-quality investigation. Unpublished geologic maps (Hugh Houghton, N.J. D partment of Environmental Protection, written commun., 1985) and published reports (Lyttle and Epstein, 1987; Vecchioli and Palmer, 1962) show the regional geology for are's that surround the NAWC.

\section{Description of Study Area}

The U.S. Naval Air Warfare Center (NAWC) is a 65-acre site in west central New Jersey. During World War II, the base was much larger and included what is in $199^{\circ}$ the Mercer County Airport (fig. 1). Current'ly, the 


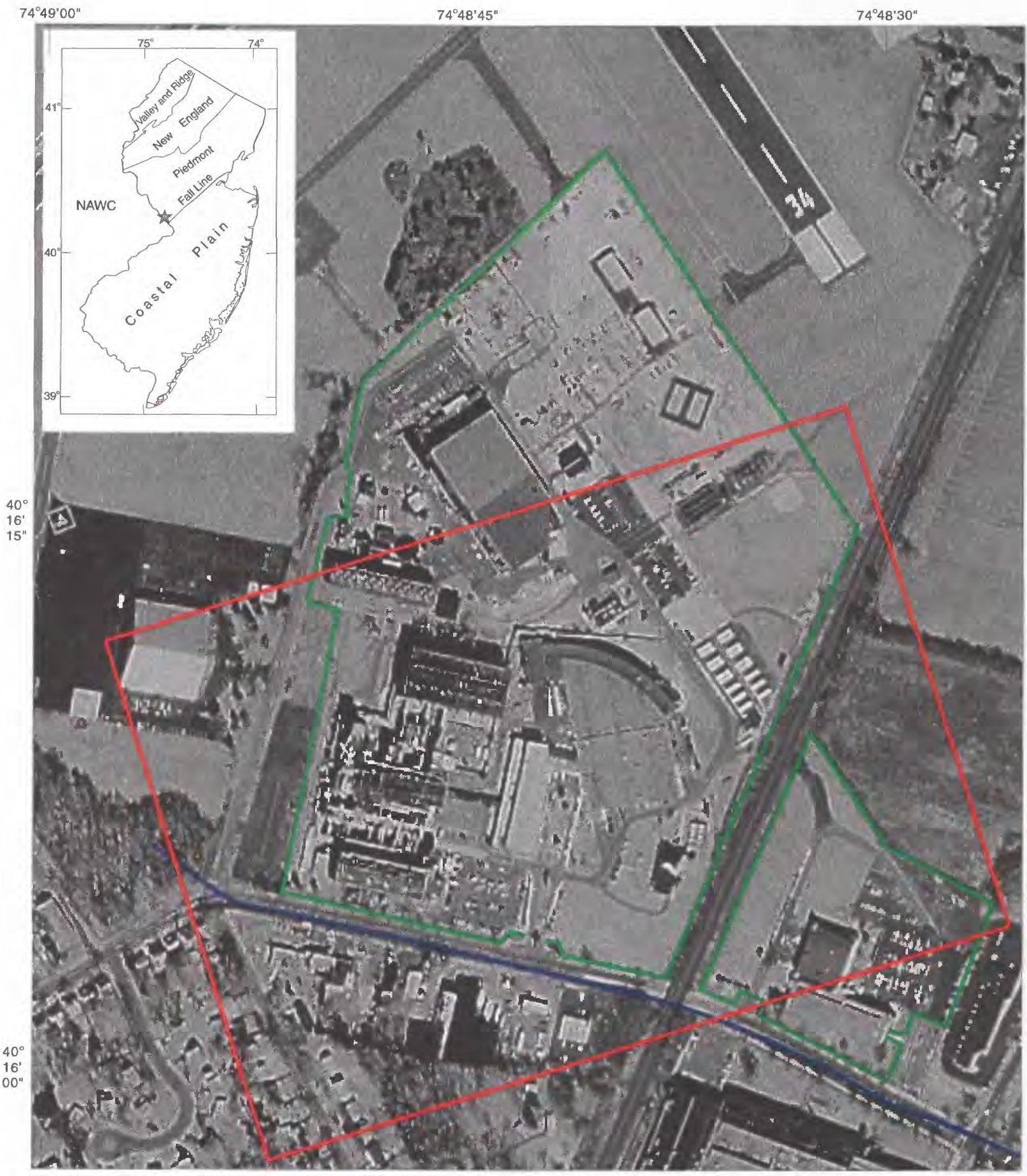

EXPLANATION
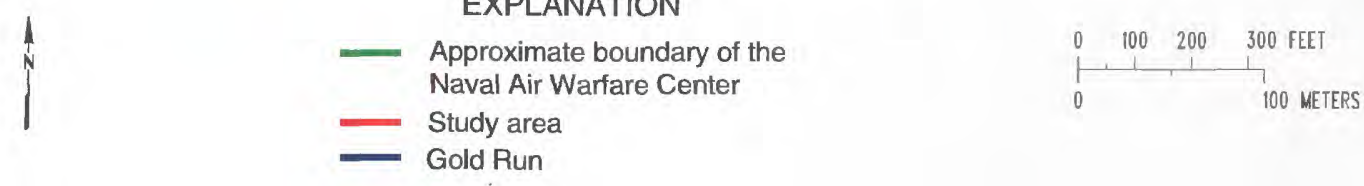

Figure 1. Digital orthophoto showing the location of the study area, Naval Air Warfare Center, West Trenton, N.J. 
base is bordered by the Mercer County Airport on the north, west, and east and by Parkway Avenue on the south (fig. 2). Commercial and industrial firms occupy the south side of Parkway Avenue. Freight train tracks separate the eastern part of the base from the western part of the base.

The base is in the Piedmont physiographic province. Bedrock in the region consists of the Lockatong Formation, which is predominantly a shale, and the Stockton Formation which is predominantly a sandstone. A thrust fault runs diagonally across the southern part of the base. The natural topography in this physiographic province is usually characterized by low rolling hills; however, much of the land has been leveled or terraced to accommodate the NAWC and airport runway. Therefore, small hills have been leveled, and small depressions have been filled. The NAWC has been terraced so that the northern part of the base has an altitude of about $170 \mathrm{ft}$, and the southern part of the base has an altitude of about $150 \mathrm{ft}$.

A spring in the wooded area near the southwest corner of NAWC flows nearly all year. The spring forms the headwaters for the West Branch of Gold Run (fig. 2). During colonial times, a trail or dirt road ran along the West Branch of Gold Run. By the early 1900's, the West Branch of Gold Run flowed in a ditch along Parkway Avenue. Sometime before 1940 the West Branch of Gold Run was confined to a culvert underneath Parkway Avenue. Today (1998), flow in the West Branch of Gold Run is visible through storm grates and at the entrance and exit culverts along Parkway Avenue.

\section{Acknowledgments}

The author would like to thank Steven Feldman and Joel Dadepogu of EA Engineering, Science, and Technology, Inc. for assistance in collection of field data during this investigation and for the technical review of the hydrogeologic interpretations. In addition, the author would like to thank Jeffery Dale, Edward Boyle, and Kenneth Smith of the U.S. Navy for guidance, direction, and historical perspective of the site. Finally, the author would like to thank Jean Brown, Otto Zapecza, Donald Rice, Thomas Imbrigiotta, and Theodore Ehlke of the USGS. These coworkers provided technical and scientific guidance, expertise, and advice on many facets of this investigation.

\section{DATA COLLECTION AND ANALYSES}

This investigation is divided into three components: hydrogeologic framework of the bedrock; ground-water levels during static, drawdown, and stressed conditions; and waterquality analysis for TCE, cis-DCE, and VC contamination. The above components are analyzed collectively so that the discussions of the framework; static, drawdown, and stressed water levels; ground-water-flow gradients and directions; surface-water flow; and water quality complement one another.

\section{Hydrogeologic Framework Development}

The hydrogeologic framework is based on geologic field observations, natural gamma-ray logs, and drilling observations at bedrock wells, hydrologic analysis of the geology, static water levels, drawdown water levels that are computed during aquifer tests, stressed water-levels measured during operation of the recovery well, water-quality data, and interpreted surface-water/ground-water interactions. The geologic component of the hydrogeologic framework was developed by mapping outcrops within 1 mile of the NAWC and from published and unpublished geologic and aero-radiometric maps of the area (Vecchioli and Palmer, 1962; Hugh Houghton, written commun., 1985; U.S. Geological 


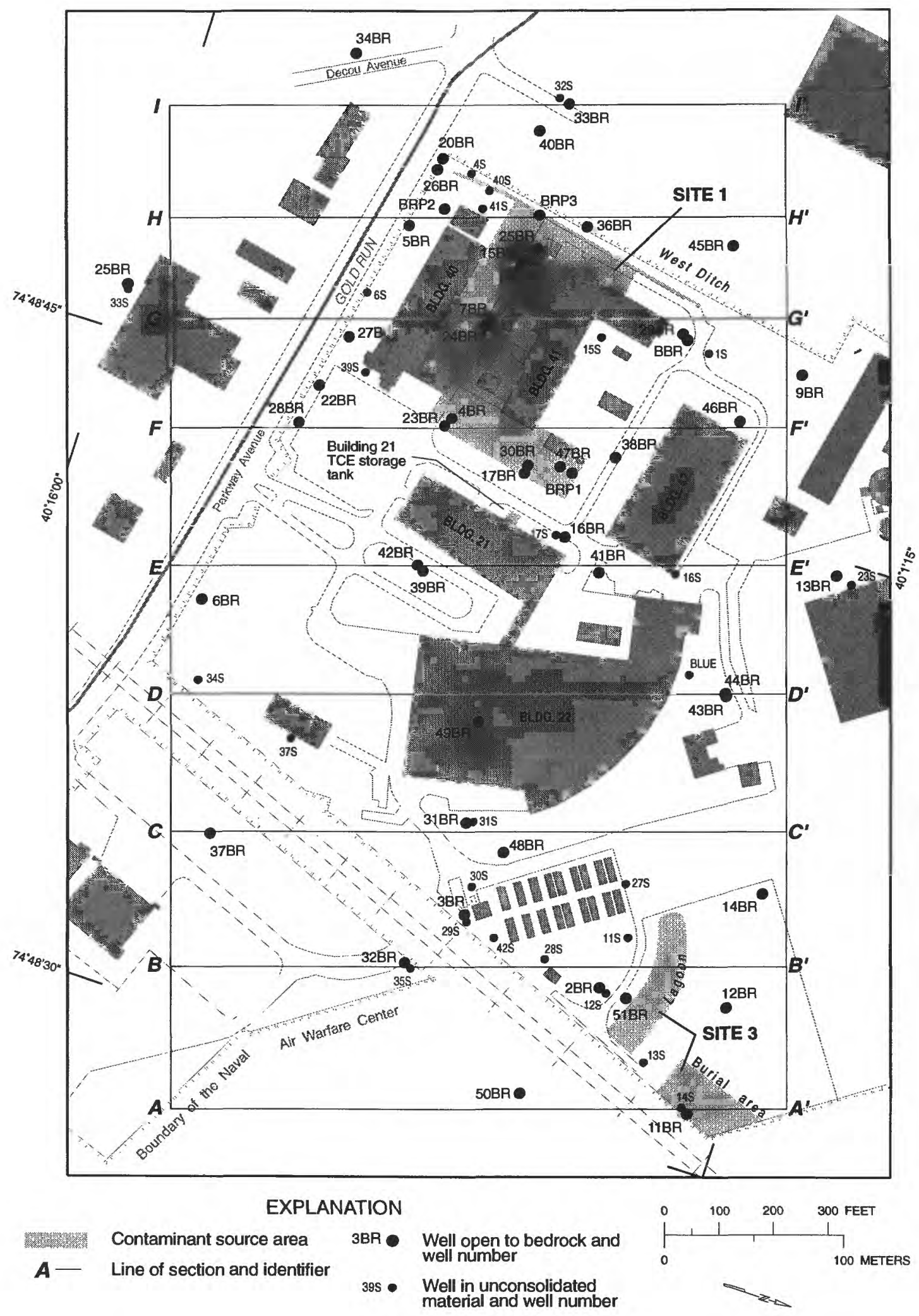

Figure 2. Study area showing location of contamination Sites 1 and 3 and location of bedrock well, Naval Air Warfare Center, West Trenton, N.J. 
Survey, 1979). The regional geologic data were enhanced on the NAWC property by review and reevaluation of geologists' and drillers' logs collected from about 50 bedrock monitoring wells (International Technology Corporation, 1994, Appendix A; EA Engineering, Science, and Technology, Inc., 1997, Appendix A), examination of short rock cores from 20 monitoring wells, examination of complete rock cores from 3 wells, and analyses of natural gamma-ray logs collected by the USGS at 25 bedrock monitoring wells.

\section{Water-Level Analyses}

The hydrologic component of the hydrogeologic framework was developed from analysis of interpreted ground-water gradients and flowpaths in the bedrock aquifer based on static water-level data collected during December 1995 (EA Engineering, Science, and Technology, Inc., February 1996, table 31). In addition, drawdown water levels computed at the end of three aquifer tests were analyzed. The aquifer tests were conducted while pumping wells $15 B R$, BRP1, and 5BR and measuring the water-level drawdown in 8 to 23 nearby wells (International Technology Corporation, 1994, table 2-2; EA Engineering, Science, and Technology, Inc., July 1996, table 5-2). The static and drawdown water-level data are complemented with stressed water-level data collected during operation of the recovery well (15BR) during August 25-27, 1997. All water-level data were collected with a chalked steel tape or an electric tape. The altitude of the measuring point was leveled in by licensed surveyors.

\section{Water-Quality Analyses}

Water quality is evaluated only with respect to TCE, cis-DCE, and VC. TCE, cisDCE, and VC values are from water samples collected during June 1997 by EA Engineering, Science, and Technology, Inc. (1997, table 1). EA Engineering, Science, and Technology, Inc., adhered to all quality assurance and quality control parameters established at the time of collection by the New Jersey Department of Environmental Protection and by the U.S. Environmental Protection Agency.

\section{Water-Level and Water-Quality Contouring Methods}

The techniques used in this study to contour water levels are significantly different from typically used "map view" techniques of contouring the potentiometric surface. In this report, water levels from monitoring wells are plotted in map and section view. Then, the maps and sections are contoured and iteratively modified until the configuration of a potentiometric surface is true in both the map view and section view. The potentiometric surface is, in part, controlled by the estimated water levels for the West Branch of Gold Run and for the spring that is west of the NAWC.

This data display and contouring method results in the following apparent discrepancies. (1) Each measurement point is at the screen interval but in the map views the data are presented so that the measurement point appears to be at land surface. (2) The potentiometric-surface contour lines appear offset in map view because the contours reflect the potentiometric surface in three dimensions. (3) More potentiometric-surface lines are shown in some section views than can be supported by available data because the contours reflect the potentiometric surface in three dimensions. If all the maps and sections are viewed as three-dimensional space, the new contouring technique defines the potentiometric surfaces more accurately than the standard technique of contouring water levels in map view only.

To show how these contouring methods were applied at the NAWC, definitions and discussion, including some fundamental ground-water concepts, are provided for (1) a 
gently dipping bedrock aquifer system underlying a small valley and (2) a gently dipping bedrock aquifer system in an area cut by a fault that acts as a confining unit.

The static water level in a monitoring well is controlled by the topography and by the hydrogeologic framework. A potentiometric surface plane encompasses zones of similar ground-water levels. The hydraulic gradients indicate the maximum difference in potentiometric surfaces irrespective of the hydraulic conductivity, whereas ground-water flowpaths indicate differences in potentiometric surface respective of the hydraulic conductivity.

A schematic map and section (figs. 3a1 and 3a2) show a hypothetical small valley underlain by gently dipping sedimentary rocks. The strike of the bedrock in the valley is sub-parallel to the flow direction of the stream, and the dip direction of the bedrock is to the right. Bedding units are labeled A through $\mathrm{G}$, and each bedding unit is composed of many water-bearing zones and semi-confining zones. Wells a to $g$ are screened in their respective bedding unit. Water levels decrease in wells a, $\mathrm{b}$, and $\mathrm{c}$ with increasing well depth, and water levels increase in wells $e, f$, and $g$ with increasing well depth. Wells $d, e, f$, and $g$ are possibly flowing wells. The water level in each well reflects the water level of the outcrop area of the bedding unit in which the well is screened.

This pattern of water-level decreases on one side of the stream and water-level increases on the other side of the stream invokes a symmetric potentiometric surface map (fig. 3b1) but an asymmetric potentiometric surface section (fig. 3b2). The equipotential planes of the section are skewed to the right so that in the shallow bedrock, the equipotential planes are parallel to the bedding units, but in deep bedrock the equipotential planes are perpendicular to the bedding units. The asymmetric potentiometric surface section indicates an anisotropic bedrock aquifer that consists of (a) numerous thin strata that act as semi-confining zones with few bedding-plane and vertical partings and that have a relatively low hydraulic conductivity and (b) numerous thin strata that act as water-bearing zones with many bedding-plane partings and that have a relatively high hydraulic conductivity.

A flow net usually is depicted as a series of orthorhombic equipotential lines and hydraulic-gradient lines. In three dimensions, a flow net is a series of orthorhombic equipotential planes and hydraulic-gradient planes. The fine-scale hydrogeologic schematic drawing (fig. 4) can be either a map view or a section view of a bedding unit. The schematic diagram depicts a suite of bedding units that are 100's of feet long and only 5 to $25 \mathrm{ft}$. across. The map/section shows that the bedrock in an anisotropic aquifer consists of the numerous thin semi-confining zones and water-bearing zones. The hydraulic conductivity of the semiconfining zone is much less than the hydraulic conductivity of the water-bearing zone. As a result of this anisotropic nature of the aquifer system, the maximum hydraulic gradient is from $A$ to $B$, whereas the preferred flowpath is from $C$ to $D$ with a minor flowpath that is from $\mathrm{E}$ to $\mathrm{F}$. This two-dimensional schematic analysis is significantly simplified. A threedimensional analysis, which is the function of a ground-water-flow model, is necessary to qualify and quantify gradient and flowpaths in a fractured-rock aquifer.

Figure 5 is a map and section view of a small valley similar to the example shown in figure 3 ; in this instance, however, a fault acts as a cross-cutting confining unit. The strike of the bedrock and the fault are parallel with the long axis of the valley, although in the upstream area the stream crosses the fault. Water levels in wells b, c, and d show decreasing water levels with depth. At the fault/confining unit, water will tend to flow in any high conductance zone such that it will flow over, under, or around the confining unit. 

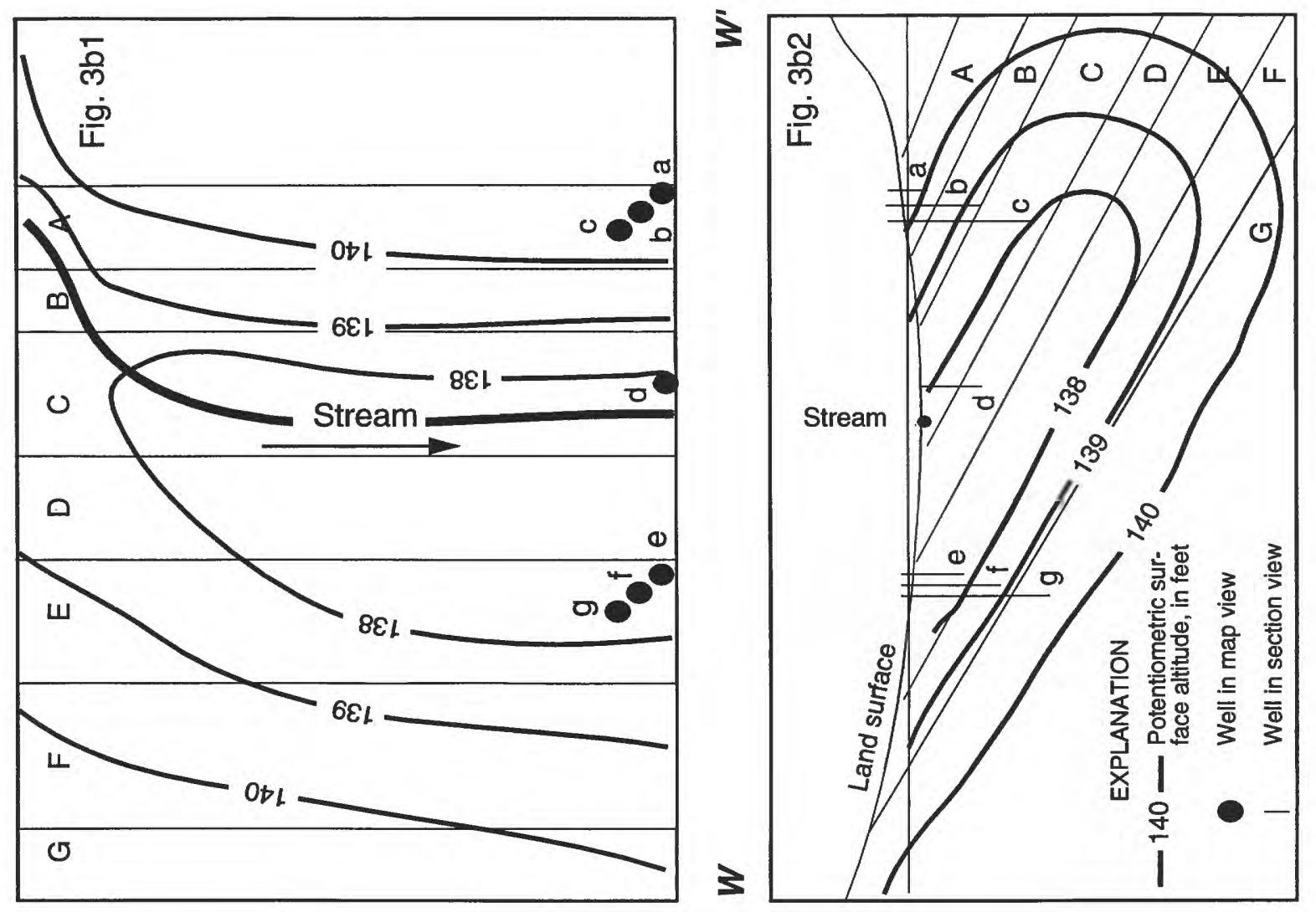

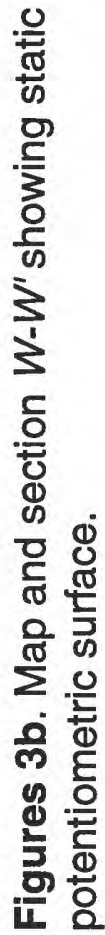
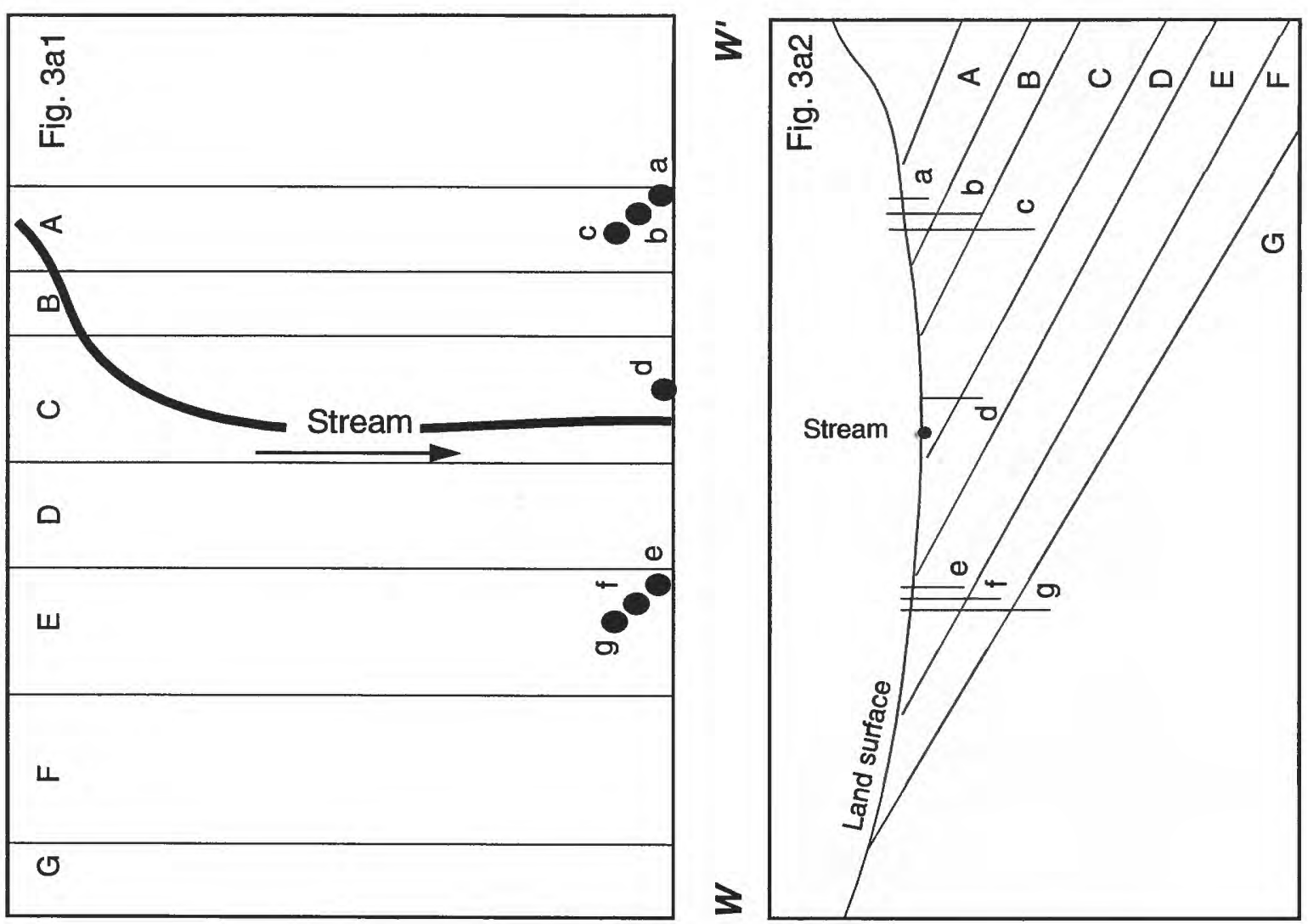

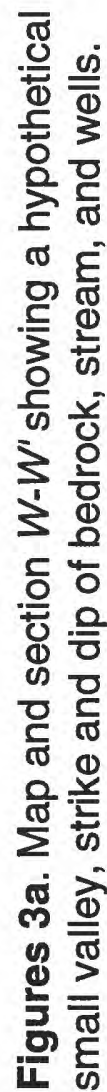




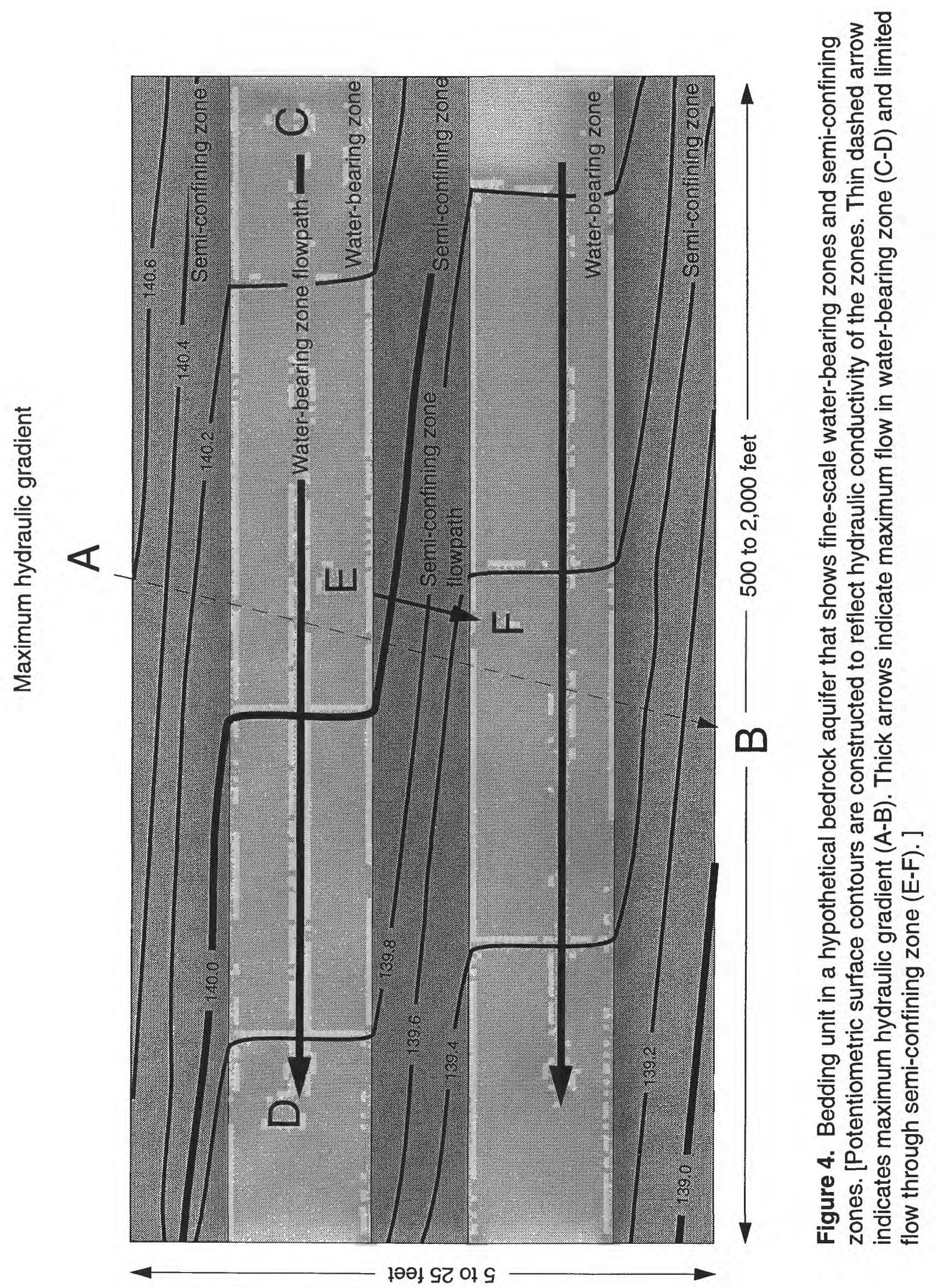



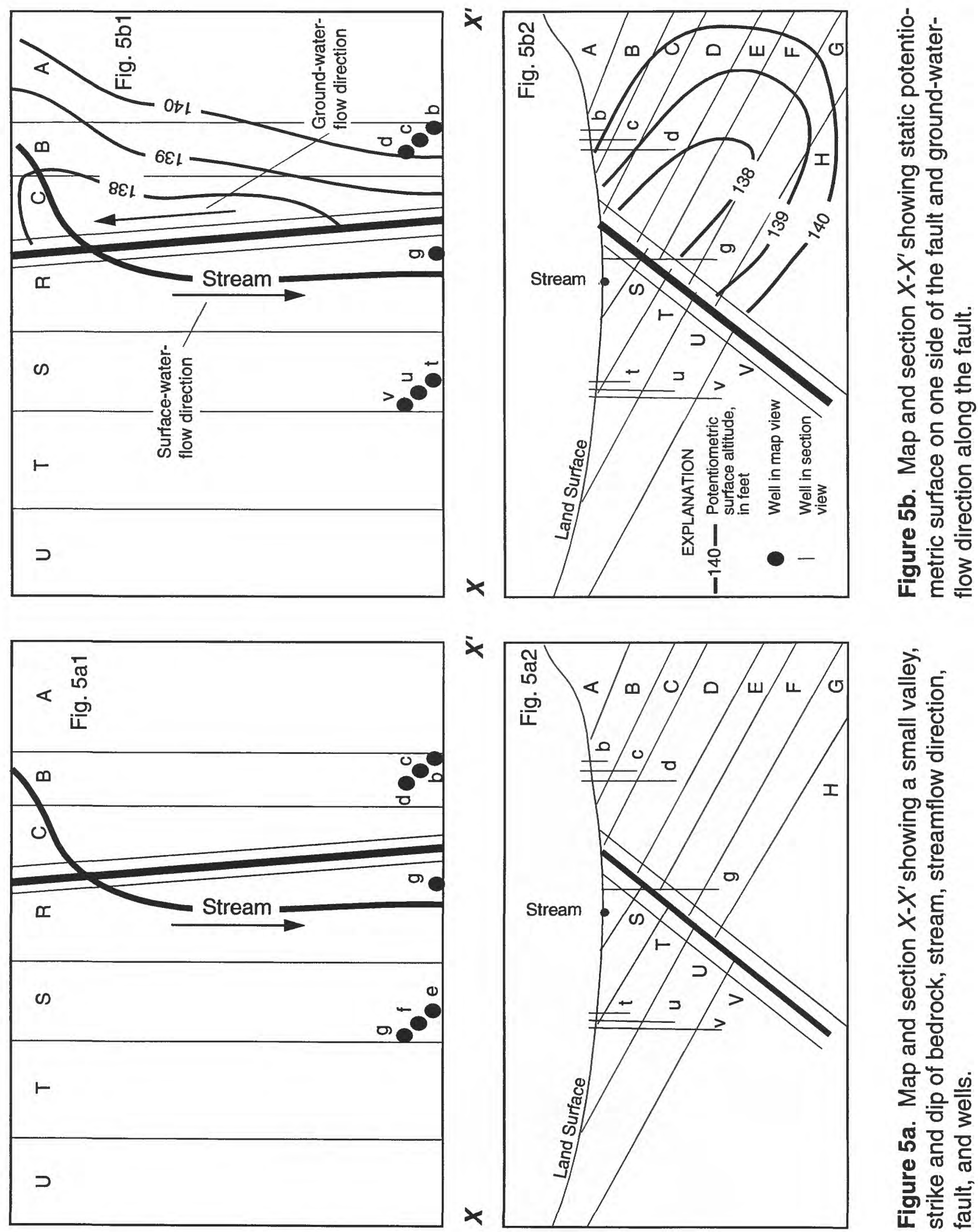
Because most bedding-plane partings close with depth in most viable bedrock aquifers, it is unlikely that water will flow under the fault. A more probable flow direction is upward; if water cannot rise high enough to flow directly over the confining unit, however, it will flow parallel to the fault/confining unit to a point of low topography, such as a spring or a stream channel, and then it will flow over the fault/ confining unit as surface water. As a result, the ground-water-flow direction will be parallel to the fault/confining unit and towards the stream. Much like the fine-scale map/section shown in figure 4, the flowpath will exist in the high conductive water-bearing zones in the bedding units, whereas the maximum hydraulic gradient will cut across many bedding units.

Drawing a potentiometric surface plane that is highly contorted in a three-dimensional space requires abandoning the typical map view contouring methods. Typical map contouring methods show a specific waterlevel altitude associated with a well and then assume the screen interval of the well is at land surface. This method of contouring may be appropriate in certain types of aquifers, but it is not accurate in the fractured bedrock aquifer at the NAWC. At the NAWC, water-level contours were drawn in three-dimensions collectively using a map at land surface, a map at $100 \mathrm{ft}$ below land surface and nine sections (sections A to I). Water-level contours were then drawn so that they show the highly contorted potentiometric surface. A residual effect of this contouring method for a map at land surface is that the water-level altitude for each well screen is printed near the well but the contours at the land surface will not reflect the printed water level. The residual of a section view is that the section will contain water-level contours but no data because the wells are not in the specific section. Typically, such maps and sections are drawn as fence diagrams, but in this study area, with the large number of wells and data points it is better to show maps and sections as individual figures. The reader will obtain the most useful information if the maps and sections are looked at as a single unit.

\section{HYDROGEOLOGIC FRAMEWORK}

The description of the hydrogeologic framework at the NAWC is based predominantly on borehole geophysical logs, roc'type, and color from rock cores and information recorded in drillers' and geologists' logs. The identification of the fault zone is based on geologic offsets in rock cores and zones of deep weathering of the bedrock. The stratigraphic framework and the fault location is further refined on the basis of static, drawdown, and stressed water levels and concentrations of TCE, cis-DCE, and VC.

\section{Bedrock Geology}

The NAWC is located along the southern flank of the Newark Basin. The basin forms a rolling lowland underlain by a thick succession of sedimentary rocks and basalt flows of Early Jurassic and Late Triassic age. The rocks generally dip gently to moderately to the north towards a large fault zone that forms the basin's northern boundary. Rocks in the Newark Basin are divided into 15 units. The Stockton and Lockatong Formations of Upper Triassic age are the only units present at the NAWC (Hugh Houghton, written commun., 1984). In this report, the author correlater the Stockton Formation with the Stockton acuifer and the Lockatong Formation with the Lockatong aquifer.

Several generations of folds affect the rocks of the Newark Basin. The basin mry have formed as a pull-apart structure with significant strike-slip movement along the larger faults. This could account for the compressional regime that produced local 
folds and thrust faults (Lyttle and Epstein, 1987). An unpublished geologic map of the Pennington Quadrangle shows that the contact between the Stockton and Lockatong Formations passes through the southern half of the NAWC (fig. 6) (Hugh Houghton, written commun., 1984). Immediately west of NAWC, the map shows a single, short northeasttrending normal fault. The fault contact was observed in a ditch that was dug to repair a fire hydrant (Donald Monteverde, N.J. Geological Survey, oral commun., 1996). Numerous faults were mapped in the bottom of Villa Victoria Brook $^{1}$ about 1 mile west-southwest of NAWC. The strikes of the faults are north to northeast, but the dip directions and dip angle of each fault were not noted. The faults are interpreted to be thrust faults.

The bedrock geology at the NAWC consists of the upper strata of the Stockton Formation and lower strata of the Lockatong Formation. Regionally and at NAWC, the contact between the two formations is gradational. In this report, a thrust fault is mapped very close to the contact between the two formations at NAWC. Bedding units in each formation (table 1) are defined on the basis of natural gamma-ray logs (figs. 7a and 7b) and reinterpretation of the lithology based on rock cores and geologists' and drillers' logs (International Technology Corporation, 1994; EA Engineering, Science and Technology Inc., 1997). The strike of the bedrock at NAWC ranges from $N 65^{\circ} \mathrm{E}$ to $\mathrm{N} 70^{\circ} \mathrm{E}$. The dip ranges from about $70^{\circ} \mathrm{NW}$ near the fault to about $15^{\circ}$ NW at a distance of more than $300 \mathrm{ft}$ from the fault. The structure of the bedding units and the thrust fault are shown in map view (figs. 8 and 9) and in sections (figs. 10 to 18). A generic block diagram shows the synform of the Lockatong Formation, antiform of the

\footnotetext{
${ }^{1}$ Villa Victoria Brook in this report refers to the unnamed brook that flows through the hamlet of Scudders Falls and Villa Victoria Academy (fig. 6).
}

Stockton Formation and the thrust fault (fig. 19).

The bedding units in each formatior consist of numerous layers or hydrogeolngic zones referred to as water-bearing zones and semi-confining zones. The water-bearing zones are areally extensive and have interconnected bedding-plane partings and vertical partings that produce water, whereas the semiconfining zones have a limited number $c^{f}$ partings or poorly connected partings that produce little water. It is not possible to accurately map the water-bearing and semiconfining zones in each bedding unit, berause the screened interval in a well typically c"osses more than one zone.

\section{Stockton Formation}

Regionally, the Stockton Formation is a light to medium gray to pale reddish brown, thin- to thick-bedded, fine- to coarse-grained sandstone interbedded with conglomerate and shale (Lyttle and Epstein, 1987). At NA'VC, the Stockton Formation is interbedded light reddish-gray sandstone and reddish mudstones that are divided into five bedding units. The bedding units are labeled S-11 through S- $15^{2}$ (table 1, figs. 8 to 18). The bedding units are based on major changes in lithotype and in color. Changes in gamma-ray signature at NAWC are not as diagnostic in the Stockton Formation as they are in the Lockatong Formation because there are not distinct layers that produce strong gamm $\mathrm{n}$-ray anomalies in the Stockton Formation (fig. 7a). As a result of the limited number of wells and shallow depth of the wells that are in the Stockton Formation, there is little information to confirm the characteristic of a bedding unit or generate well-defined structure maps of the unit.

\footnotetext{
2 ' $S$ ' is a prefix for Stockton Formation strata and ' $L$ ' is prefix for Lockatong Formation.
} 
On the basis of the change in rock color and sediment grain size, the contact of the Stockton with the Lockatong Formation at NAWC probably is conformable and located at the contact of bedding units S-15 and L-1. The transition represents a change in the environment of deposition from a shallow near-shore environment to a deep water, far from shore environment.

\section{Lockatong Formation}

Regionally, the Lockatong Formation consists of laminated to thick-bedded, gray and black siltstones and shales (Lyttle and Epstein, 1987). At NAWC, the Lockatong Formation consists of laminated to thickbedded gray, greenish-gray, reddish, and black mudstones. In the study area, the formation is divided into bedding units $\mathrm{L}-1$ and $\mathrm{L}-2$ on the south side of the thrust fault and bedding units L-13 to L-23 on the north side of the fault (table 1, figs. 8 to 18 ). Bedding units L-13 to L-23 are divided on the basis of the magnitude of the natural gamma-ray signature (fig. 7b). Bedding units L-14, L-16, L-18, and L-20 have high gamma-ray counts that result from uranium enrichment of strata within the unit. Bedding units L-13, L-15, L-17, and L-19 have low gamma-ray counts. Bedding units L-21 to L-23 also have low gamma-ray counts but are divided into 3 units based on the greenish rock color of strata L-22 and dark grayish color of strata L-21 and L-23.

Bedding units close to the fault appear to be thicker than the same bedding units at a distance from the fault because of the steeper dip of the beds where measured near the fault. Bedding unit L-20 (fig. 7b) in wells 38BR, 40BR, 41BR, 43BR, 44BR, 45BR, and 46BR show a thin high-amplitude gamma-ray anomaly, whereas wells $2 \mathrm{BR}$ and 51BR show a very broad anomaly that results from steeply dipping beds. Bedding units near land surface typically lose the high-amplitude gamma-ray signature when uranium is mobilized in an oxidizing environment. The high gamma-ray count in bedding unit L-20 does not appear in the top of well 30BR because the uranium was dissolved from this unit sometime in the geologic past.

The Lockatong Formation consists of a basal section identified as L-1 and L-2. Because of the fault, the relation of bedding units L-1 and L-2 on the south side of the fault and bedding units L-13 to L-23 on the north side of the fault is unclear. The units on the north side of the fault are interpreted to be stratigraphically higher in the section. Bedding units L-13, L-14, L-16, L-18, L-19, L-20, and L-21 are predominantly dark gray mudstone with minor beds of green gray mudstones. Bedding units L- 15 and L-17 are predominantly red mudstones and bedding unit L- 22 is a greenish gray mudstone.

\section{Fault Zone}

Based on bedrock core data from monitoring well sites at NAWC, a thrust fault cuts across the facility. The trace of the thrust fault closely follows the contact of the Lockatong and Stockton Formations as mapped by the New Jersey Department of Environmental Protection (Hugh Houghton, written commun., 1985), and the fault is subparallel with the strike of the two formations. (fig. 6).

The best evidence of a fault zone is in rock cores from well $42 \mathrm{BR}$ at depths of 68 , 111 , and $127 \mathrm{ft}$ below land surface (figs. 20 , 21 , and 22). Evidence of faulting consists of stratigraphic layers showing bedding offsets, brecciated zones, and slickensides. Rock core from a depth of $68 \mathrm{ft}$ below land surface (fig. 20 ) shows a brecciated rock zone cemented with calcite. Bedding above and below the fault has a measured dip angle of $45^{\circ}$ and an interpreted dip direction of $\mathrm{N} 20^{\circ} \mathrm{W}$. The fault has a measured dip angle of $50^{\circ}$ and an interpreted dip direction of about $\mathrm{S} 20^{\circ} \mathrm{E}$. Rock core from a depth of $111 \mathrm{ft}$ below land surface 

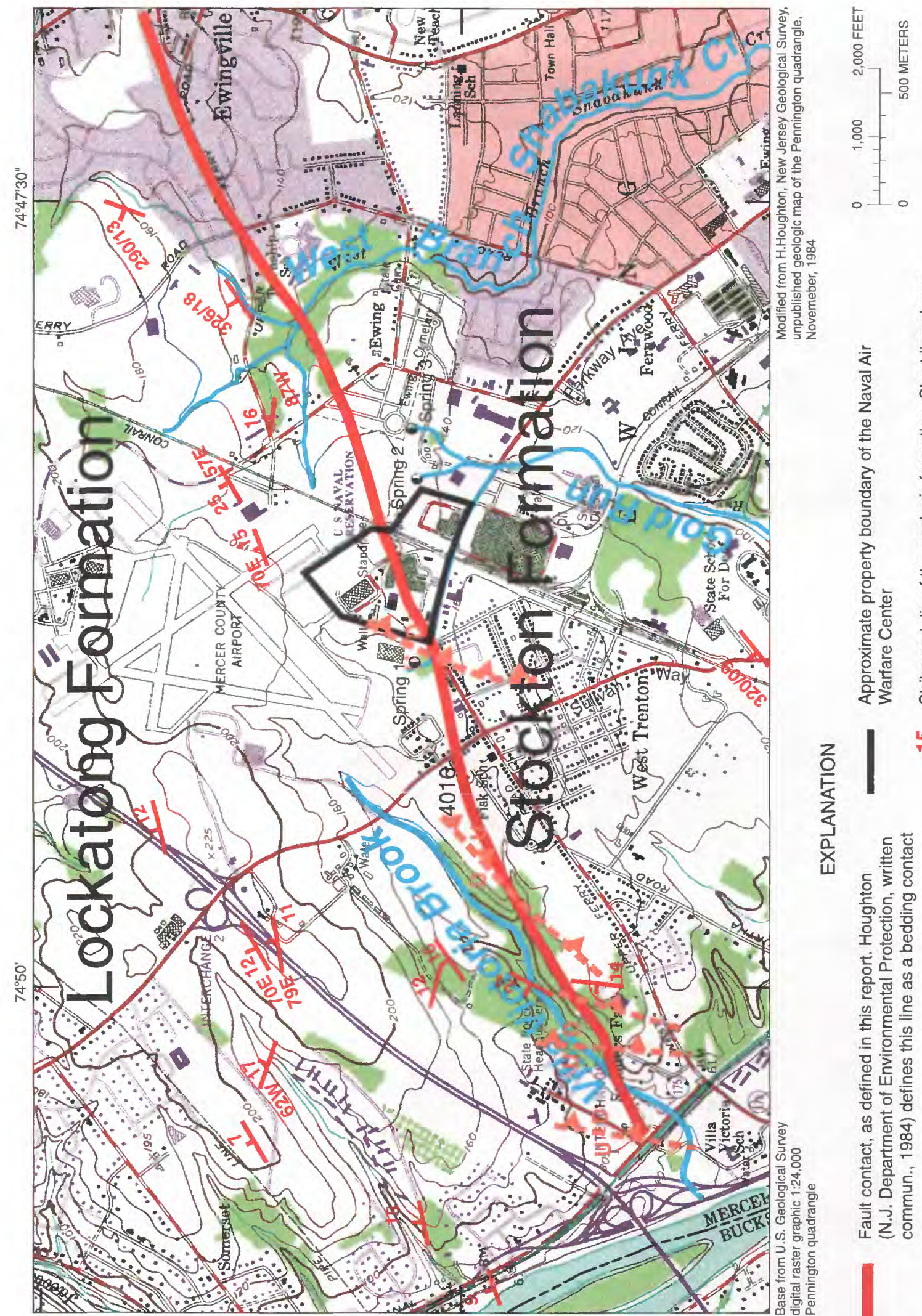
Table 1. Bedding units at the Naval Air Warfare Center based on the natural gamma-ray logs, driller's logs, and core logs

\begin{tabular}{|c|c|c|c|c|c|c|}
\hline Era & 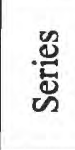 & 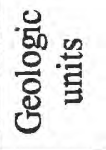 & 总 & $\begin{array}{l}\text { Bedding } \\
\text { unit }\end{array}$ & Predominate lithology and hydrology & $\begin{array}{l}\text { Hydraulic } \\
\text { character }\end{array}$ \\
\hline \multirow{20}{*}{$\begin{array}{c}0 \\
0 \\
0 \\
N \\
0 \\
0 \\
0 \\
\sum\end{array}$} & \multirow{20}{*}{ 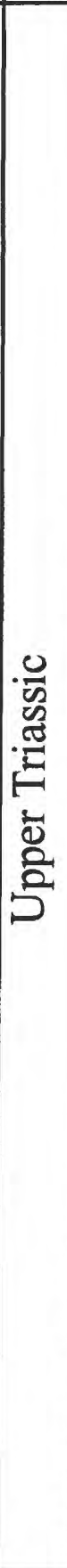 } & \multirow{15}{*}{ 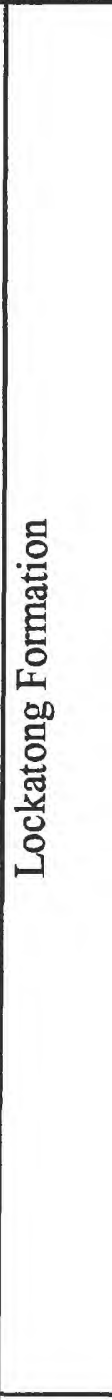 } & \multirow{15}{*}{ 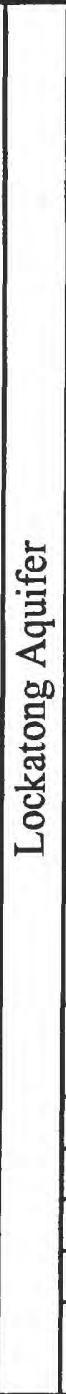 } & $\overline{\mathrm{L}-23}$ & $\begin{array}{l}\text { MUDSTONE. light to dark gray, laminated } \\
\text { slightly calcareous, low gamma count }\end{array}$ & Not applicable \\
\hline & & & & $\mathrm{L}-22$ & $\begin{array}{l}\text { MUDSTONE, dark gray and green-gray, } \\
\text { low gamma count }\end{array}$ & Not applicable \\
\hline & & & & L-21 & $\begin{array}{l}\text { MUDSTONE, gray, platy, massive, interbedded, } \\
\text { medium hard, low gamma zone }\end{array}$ & Not applicable \\
\hline & & & & $\mathrm{L}-20$ & MUDSTONE, gray, high gamma count & $\begin{array}{l}\text { Semi-confining } \\
\text { unit }\end{array}$ \\
\hline & & & & L-19 & $\begin{array}{l}\text { MUDSTONE, gray, hard to medium hard, with } \\
\text { calcareous and soft brown mudstone seams } \\
\text { low gamma zone }\end{array}$ & Not applicable \\
\hline & & & & L-18 & $\begin{array}{l}\text { SILTSTONE, MUDSTONE light to dark olive } \\
\text { green or black, massive, bioturbidation, pyrite, } \\
\text { fracture zone, some finely laminated, strongly } \\
\text { calcareous, high gamma count }\end{array}$ & Not applicable \\
\hline & & & & $\mathrm{L}-17$ & $\begin{array}{l}\text { MUDSTONE, red brown to green-gray brown, } \\
\text { low gamma zone }\end{array}$ & Not applicable \\
\hline & & & & $\mathrm{L}-16$ & $\begin{array}{l}\text { MUDSTONE, ARGILLITE, and SHALE, light } \\
\text { green to gray and black, high gamma zone }\end{array}$ & Not applicable \\
\hline & & & & L-15 & $\begin{array}{l}\text { MUDSTONE, red brown and green-gray, soft, } \\
\text { slightly broken, massive bedded, calcareous, } \\
\text { low gamma zone }\end{array}$ & Not applicable \\
\hline & & & & L-14 & $\begin{array}{l}\text { MUDSTONE, dark gray to green-gray, } \\
\text { high gamma zone }\end{array}$ & Not applicable \\
\hline & & & & L-13 & MUDSTONE, dark gray, low gamma zone & Not applicable \\
\hline & & & & & Stratigraphic relation unknown & Not applicable \\
\hline & & & & $\mathrm{L}-3$ & No data & Not applicable \\
\hline & & & & $\mathrm{L}-2$ & MUDSTONE, greenish gray, low gamma zone & Not applicable \\
\hline & & & & L-1 & $\begin{array}{l}\text { MUDSTONE, medium to dark gray, laminated, } \\
\text { high gamma zone }\end{array}$ & Not applicable \\
\hline & & \multirow{5}{*}{ 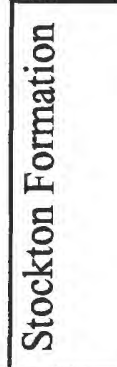 } & \multirow{5}{*}{ 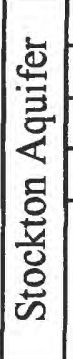 } & S-15 & SANDSTONE, brown, medium hard & Not applicable \\
\hline & & & & S-14 & SANDSTONE, gray white, medium hard & Not applicable \\
\hline & & & & S-13 & MUDSTONE red, hard, massive & Not applicable \\
\hline & & & & S-12 & SANDSTONE, gray white & Not applicable \\
\hline & & & & S-11 & MUDSTONE, red & Not applicable \\
\hline
\end{tabular}




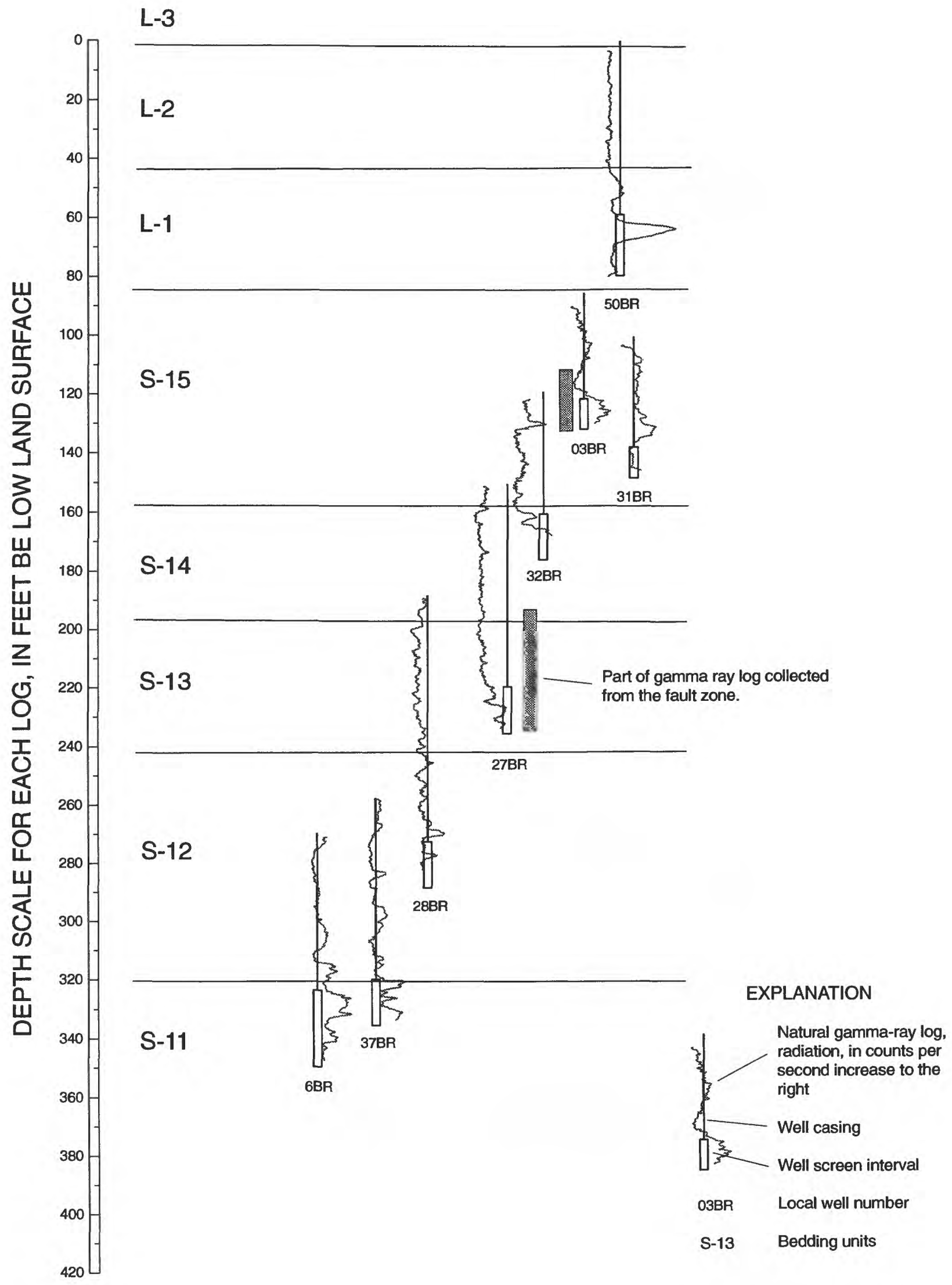

Figure 7a. Bedding units of the Stockton and Lockatong Formations south of the fault, Naval Air Warfare Center, West Trenton, N.J. [Bedding units based on natural gamma-ray logs, rock type, and rock color.] 


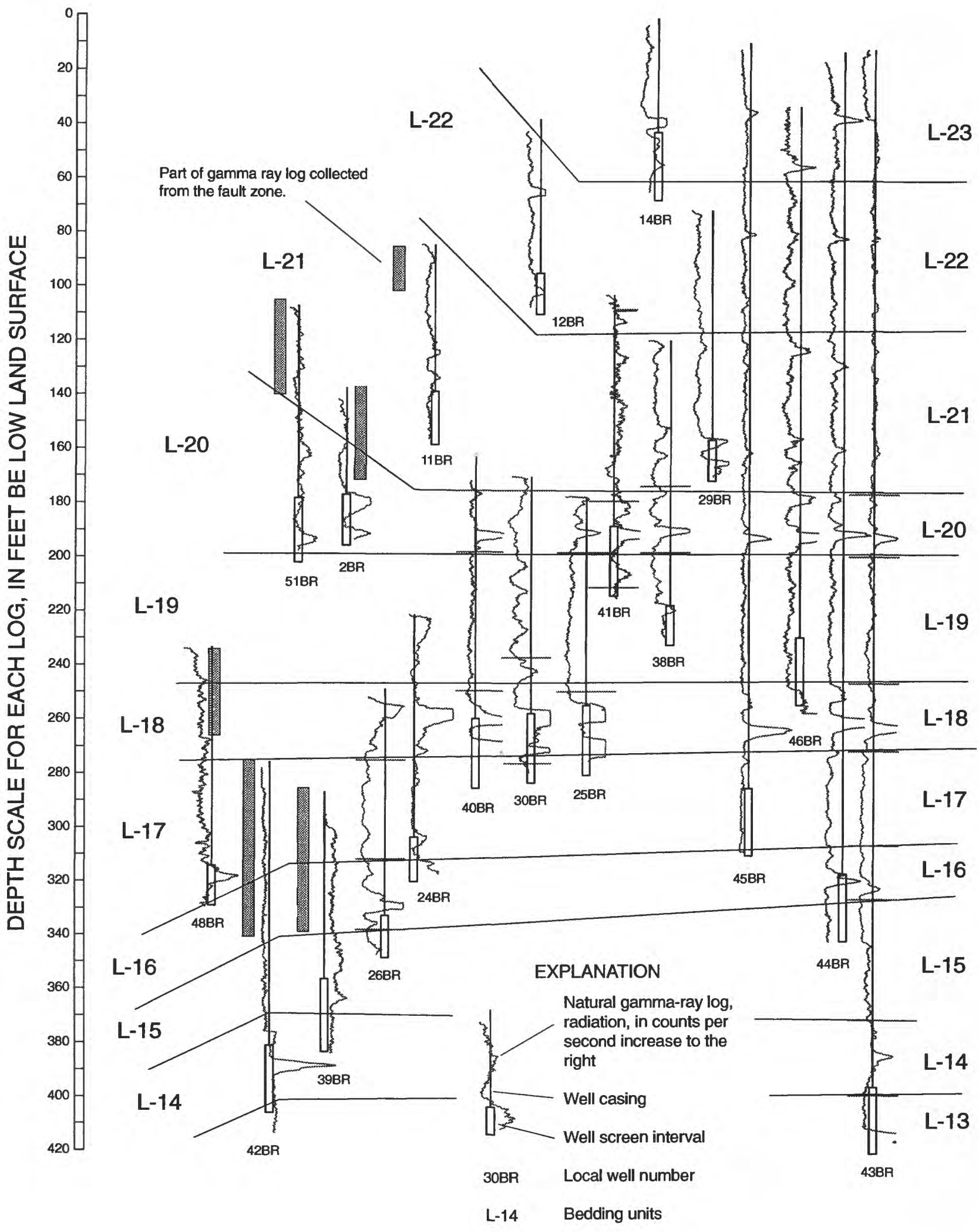

Figure 7b. Bedding units of the Lockatong Formation north of the fault, Naval Air Warfare Center, West Trenton, N.J. [Bedding units based on natural gamma-ray logs, rock type, and rock color.] 

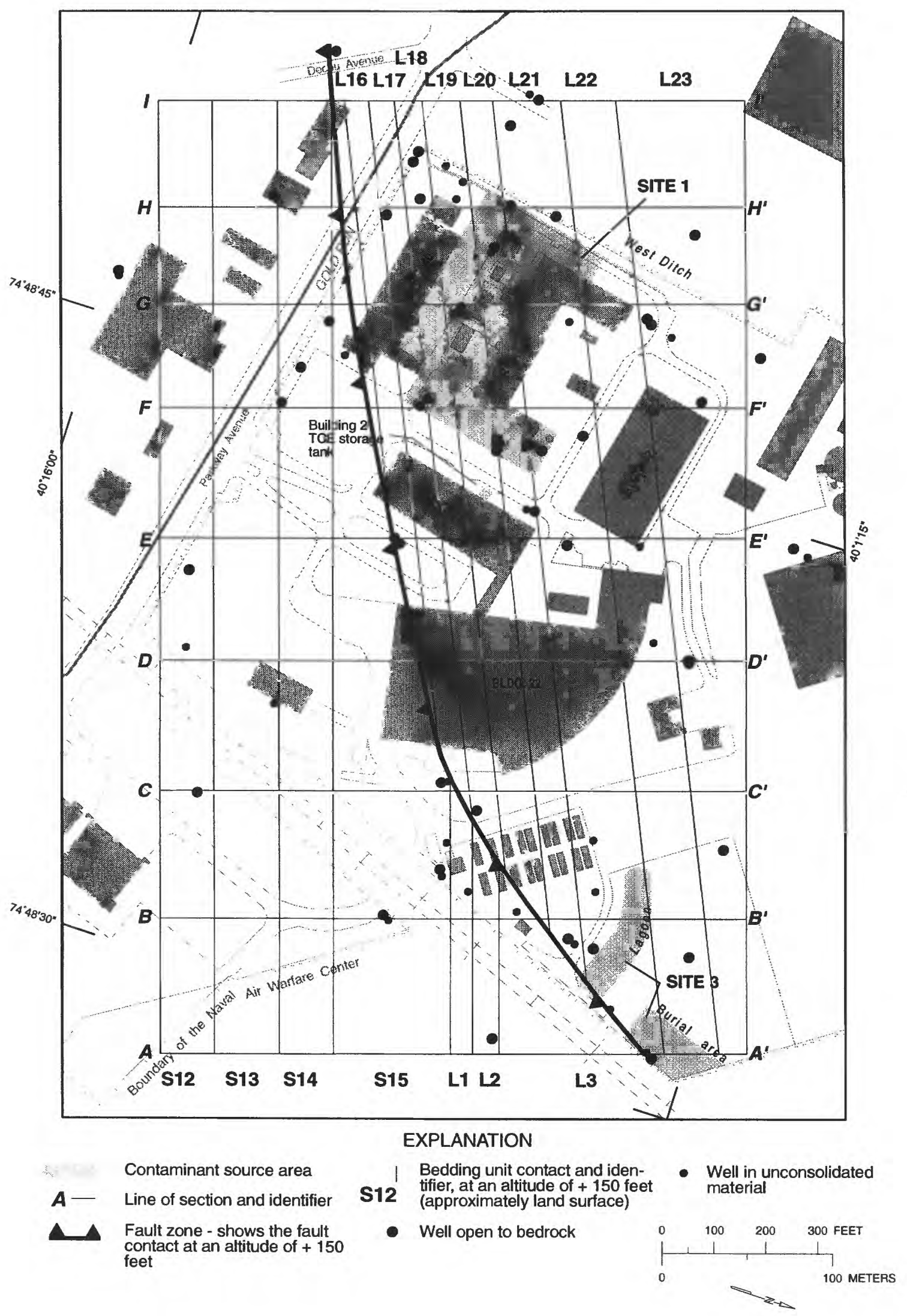

Figure 8. Bedding units and the fault trace at an altitude of +150 feet (approximately land surface), Naval Air Warfare Center, West Trenton, N.J. 


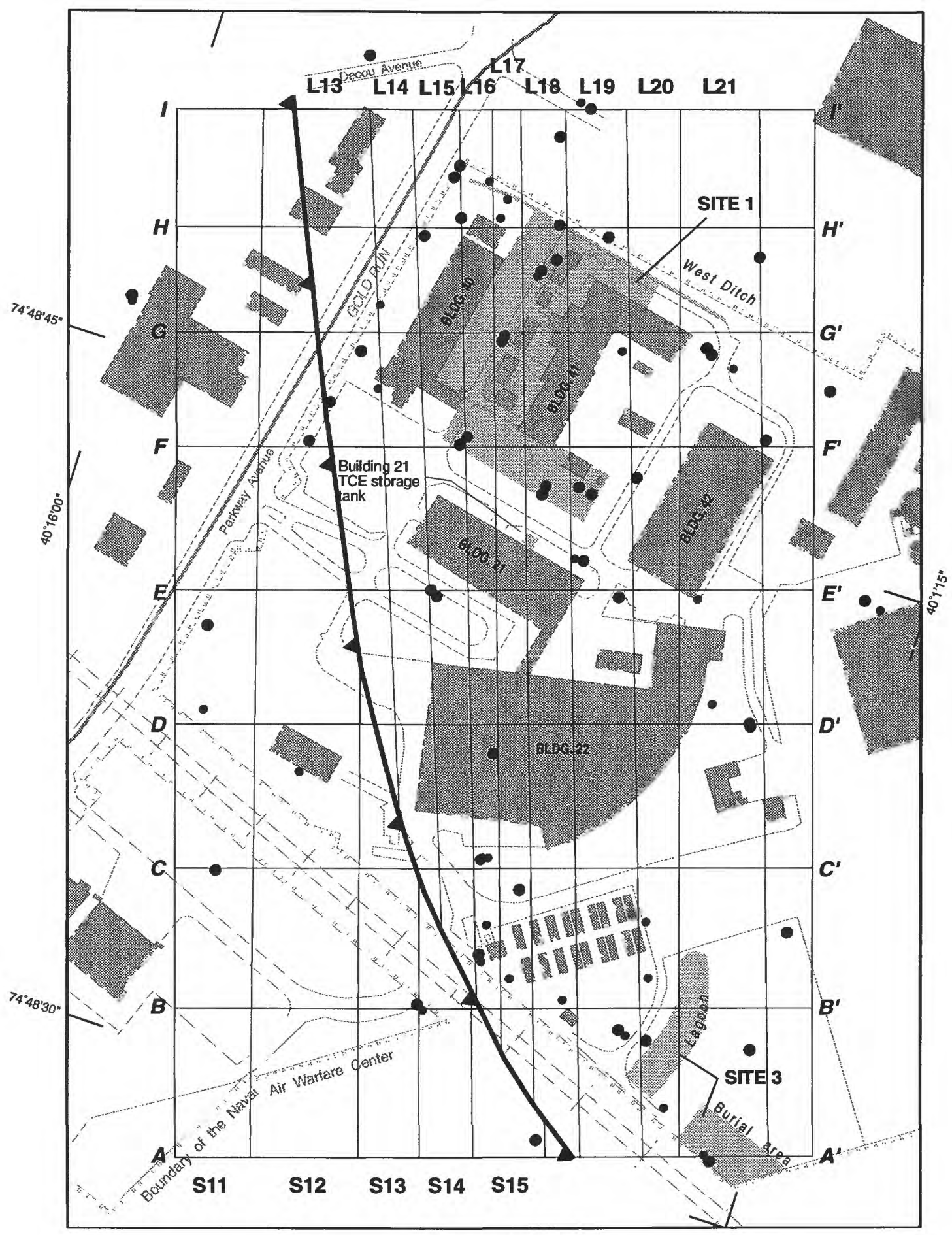

EXPLANATION
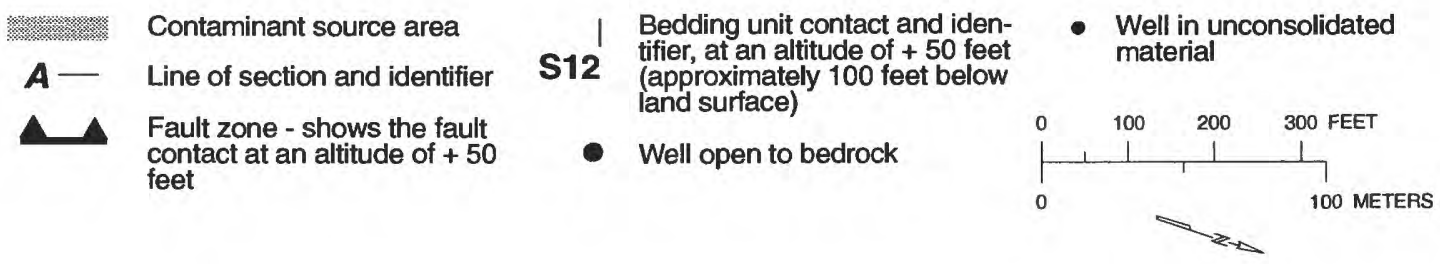

Figure 9. Bedding units and the fault trace at an altitude of +50 feet (approximately 100 feet below land surface), Naval Air Warfare Center, West Trenton, N.J. 
¿

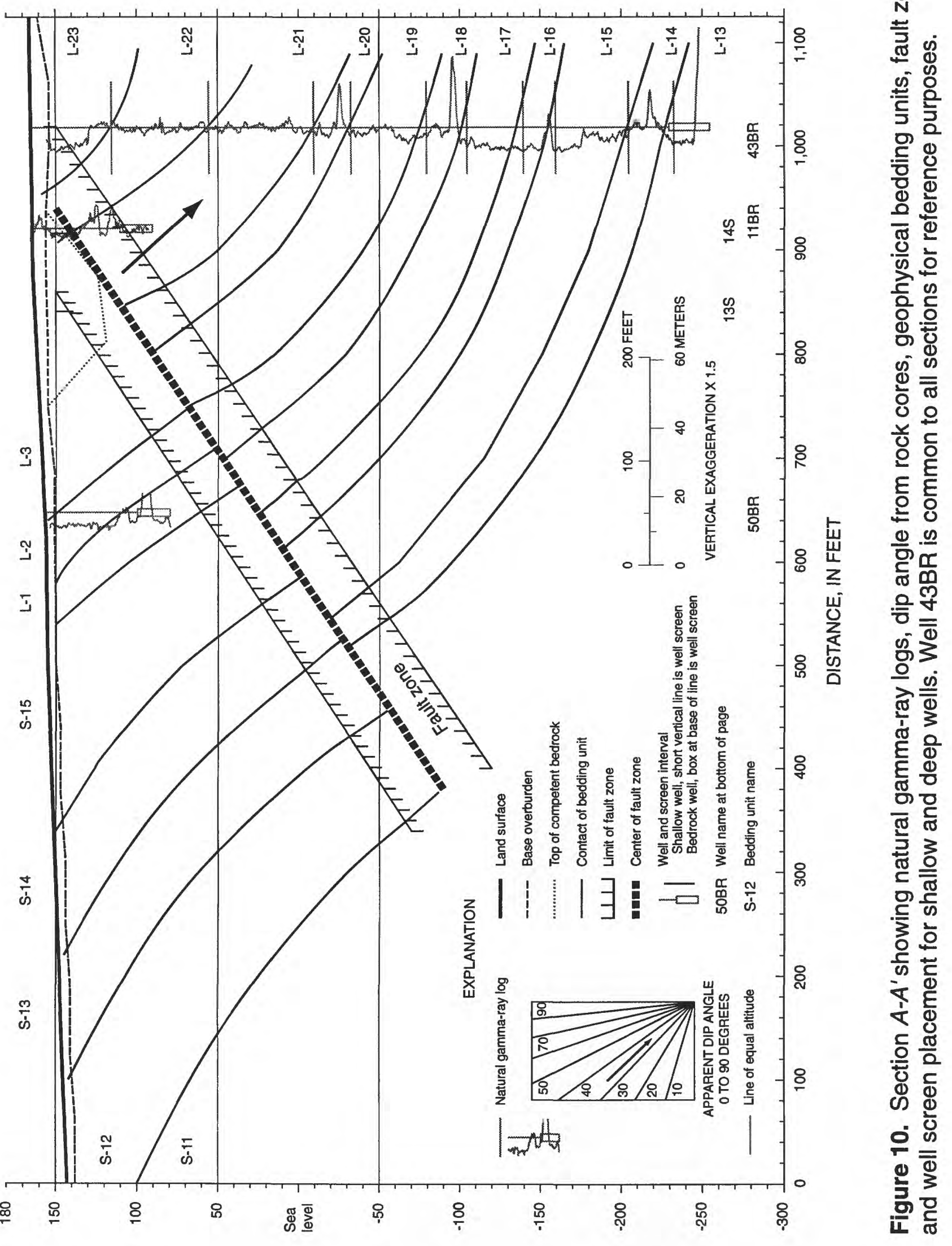


ต

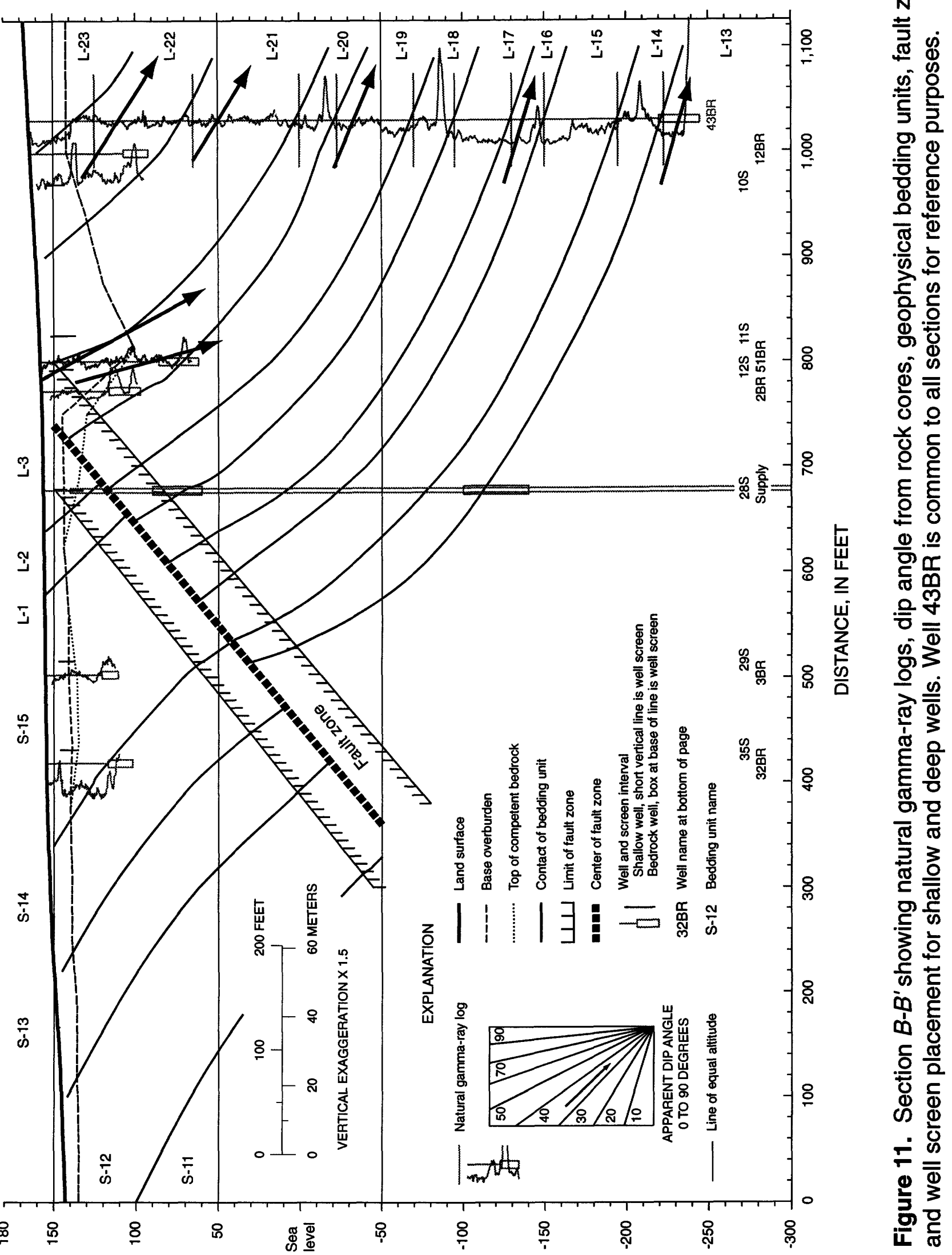


j

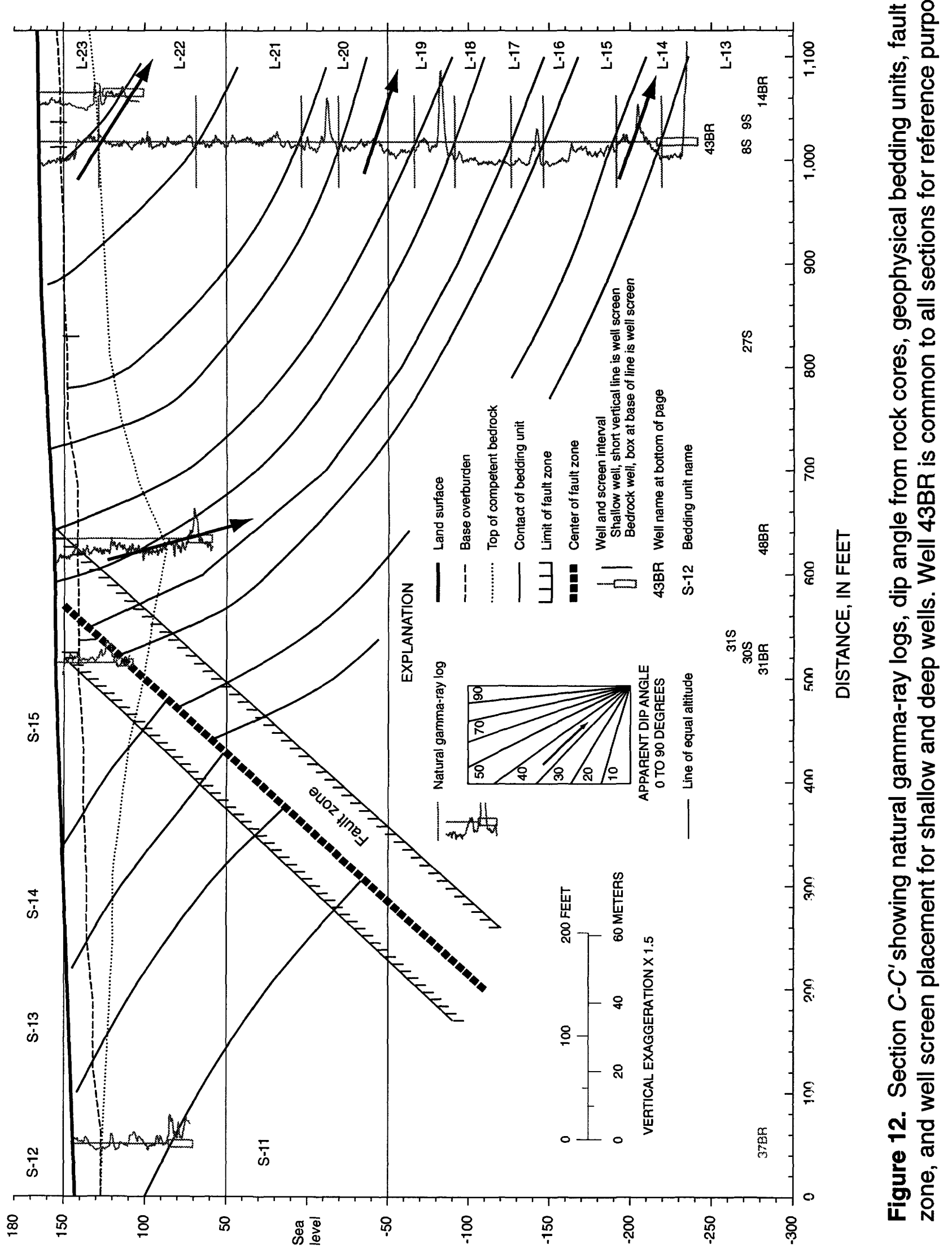


o

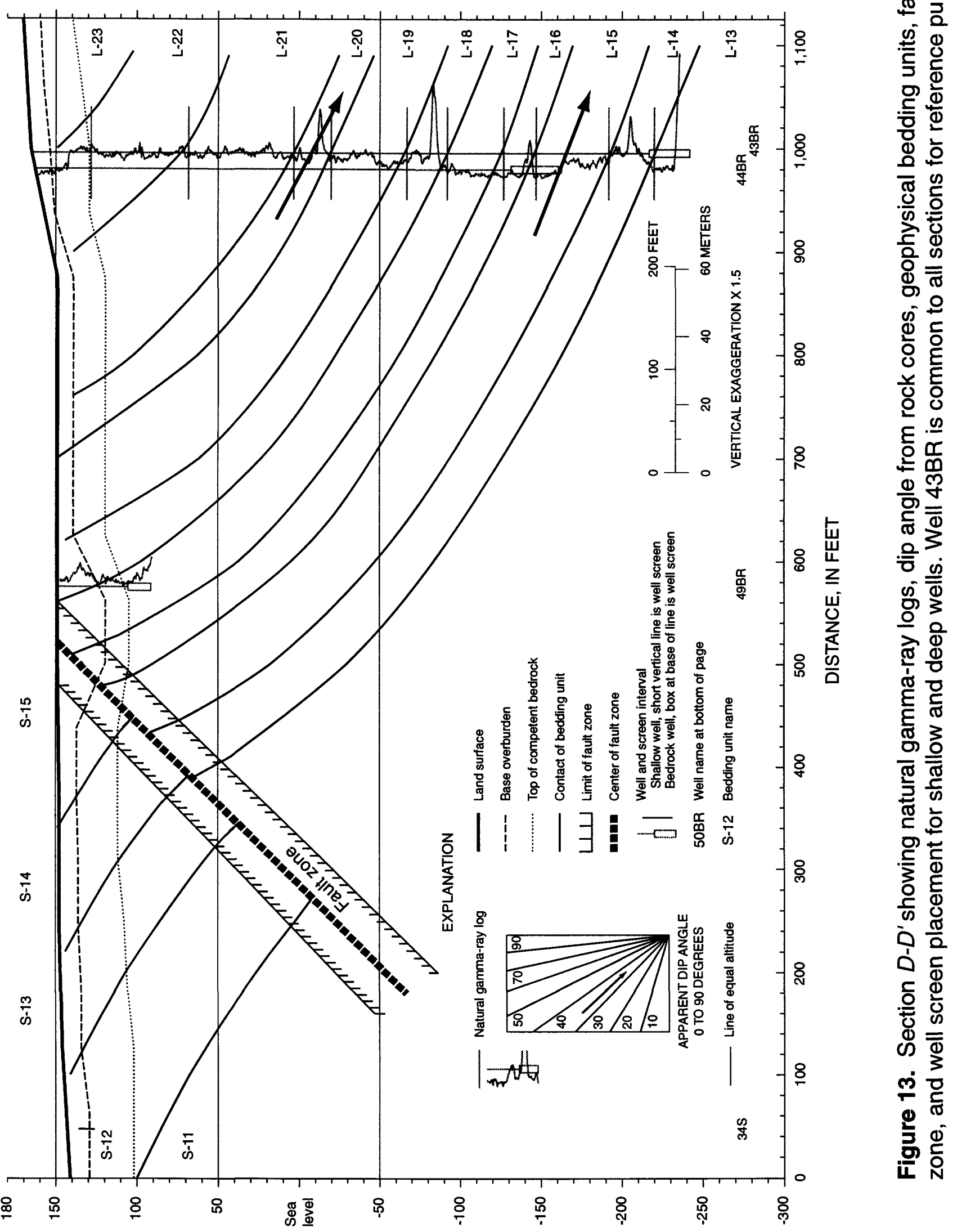


u

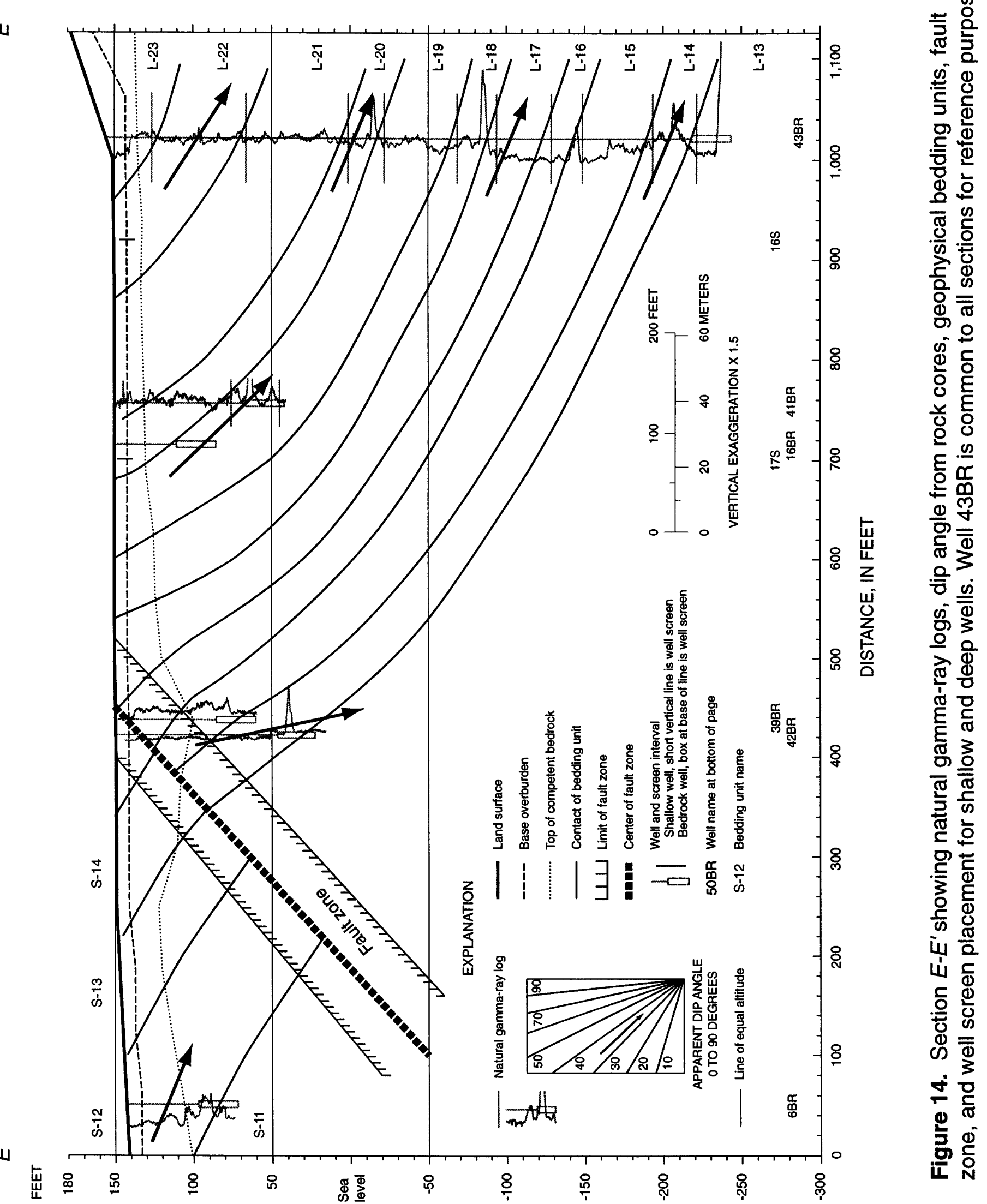


is

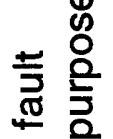

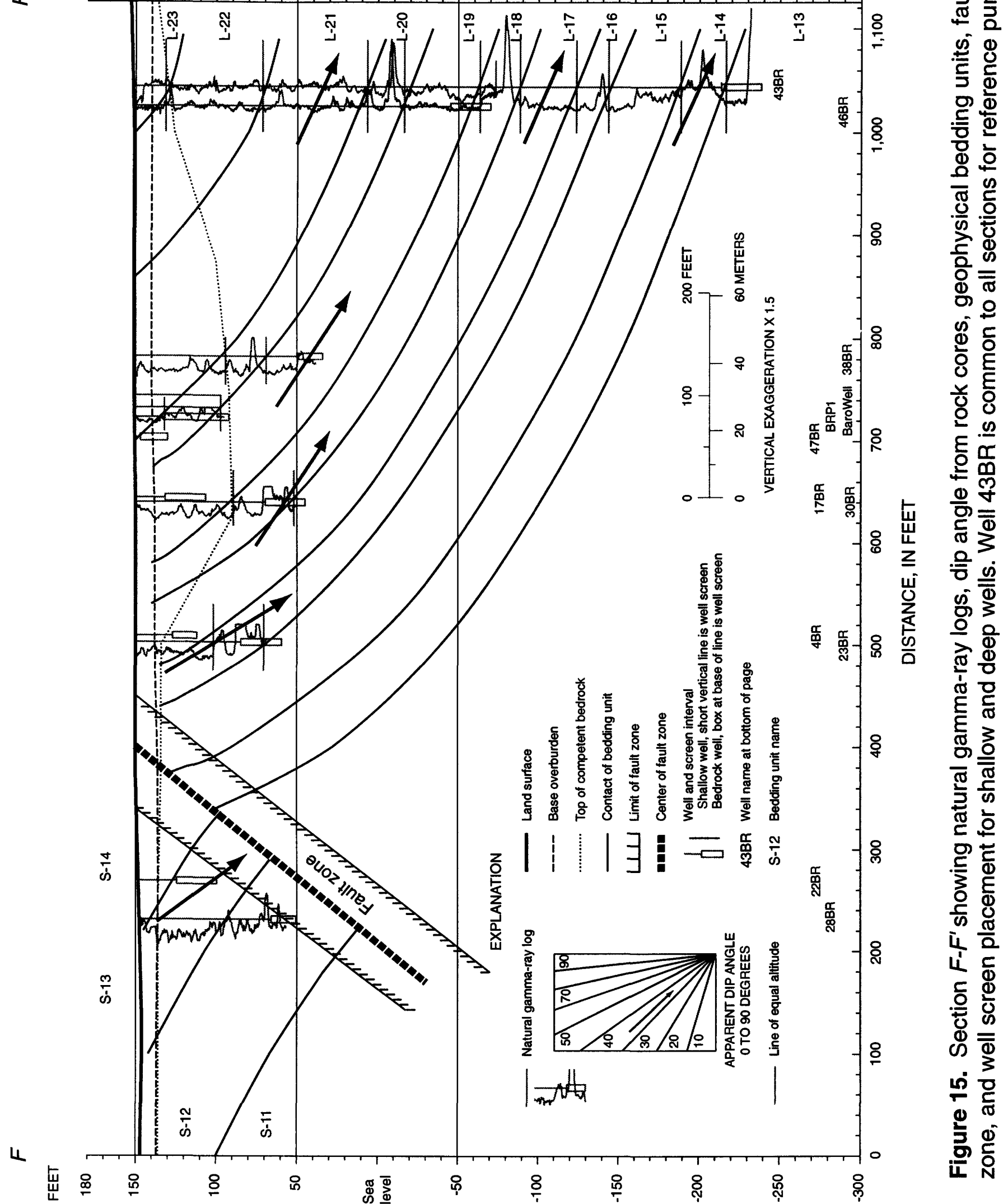


ல

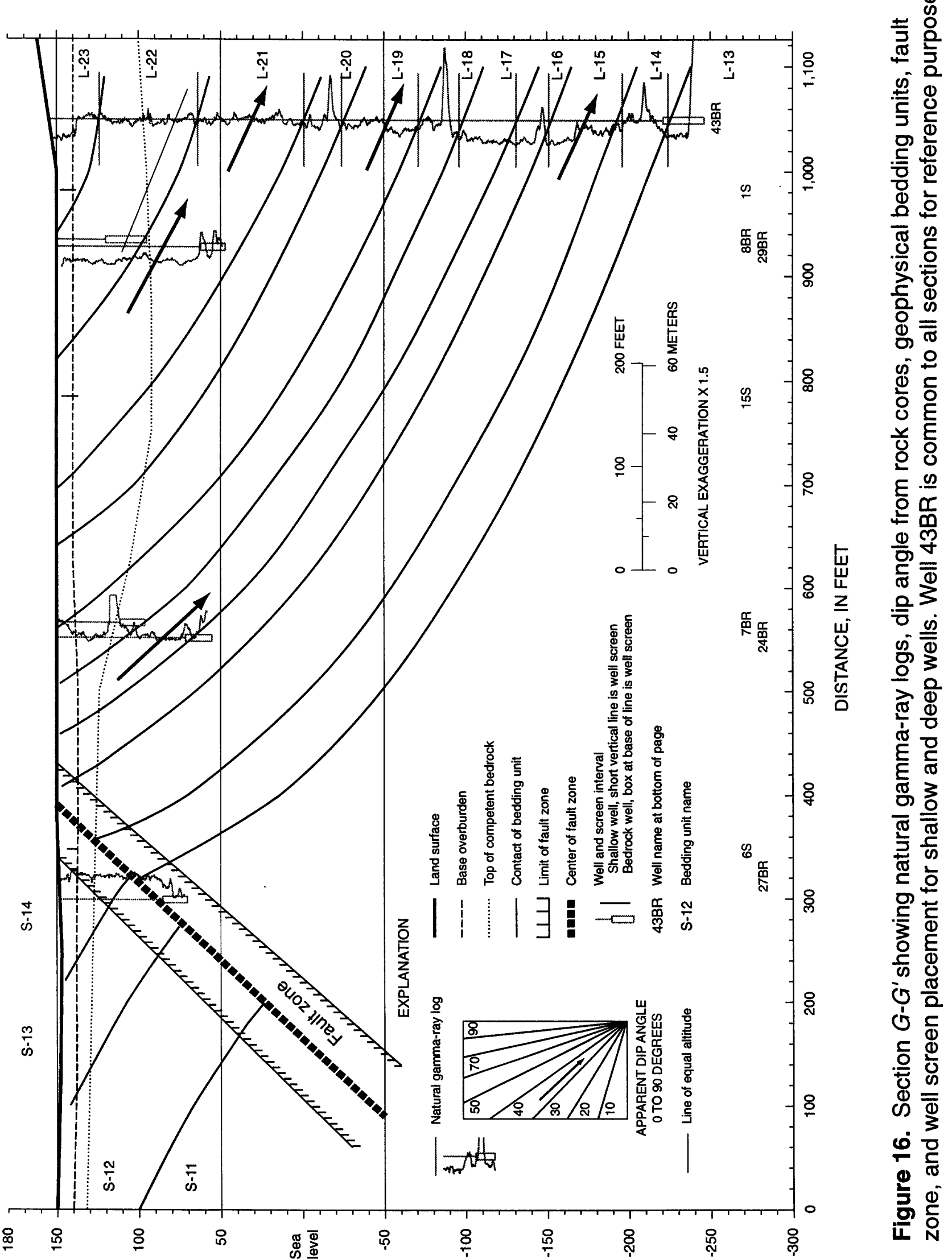


i

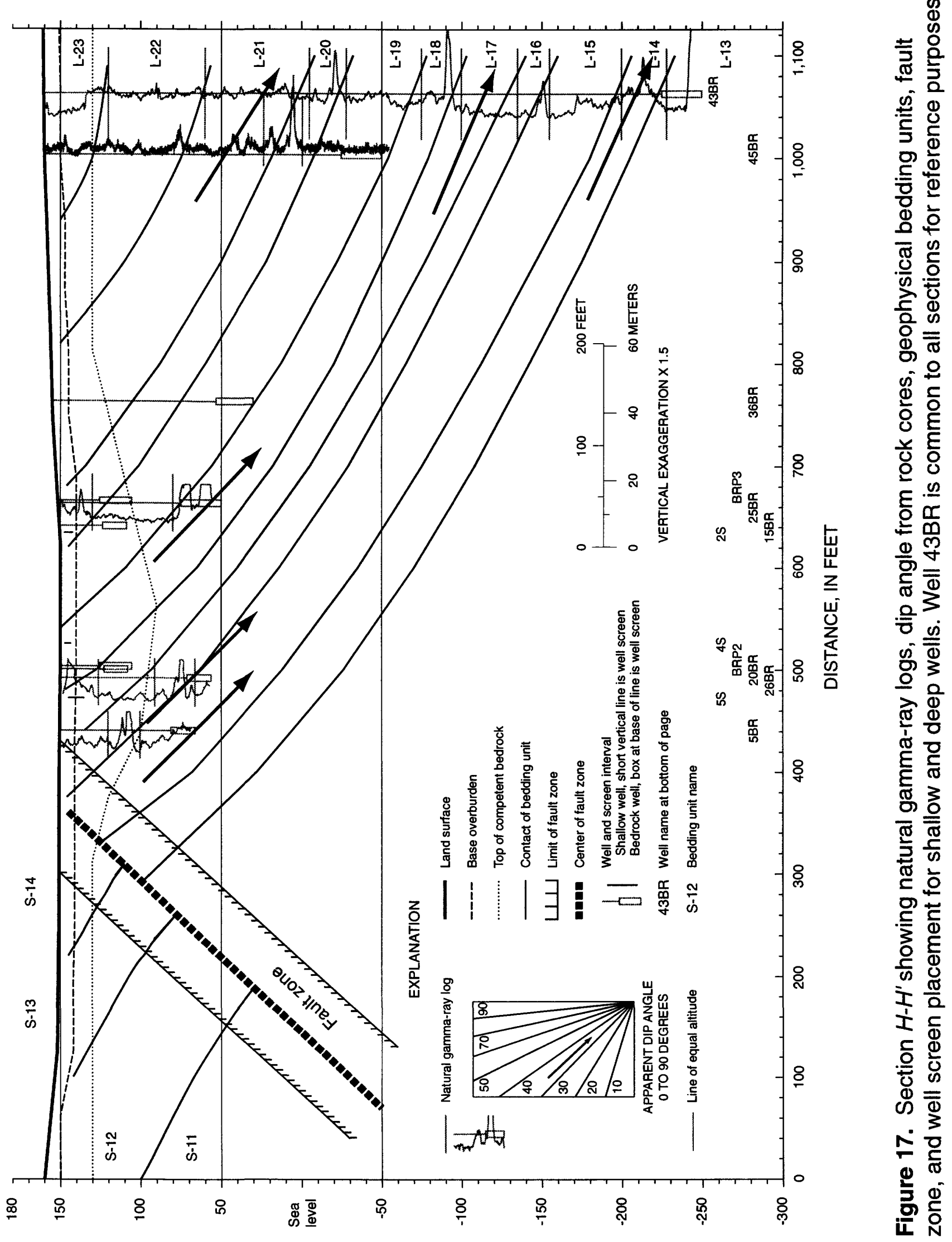




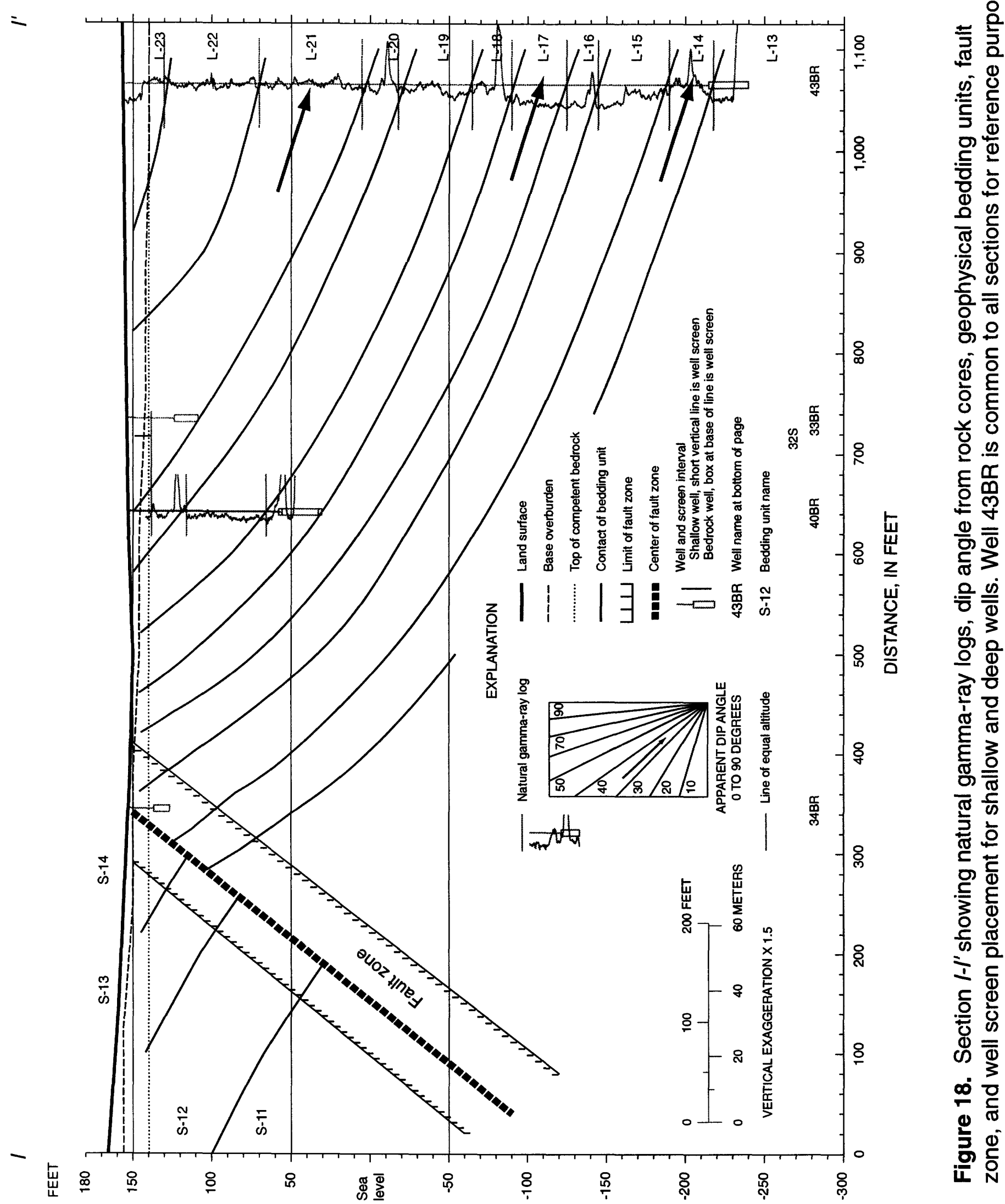




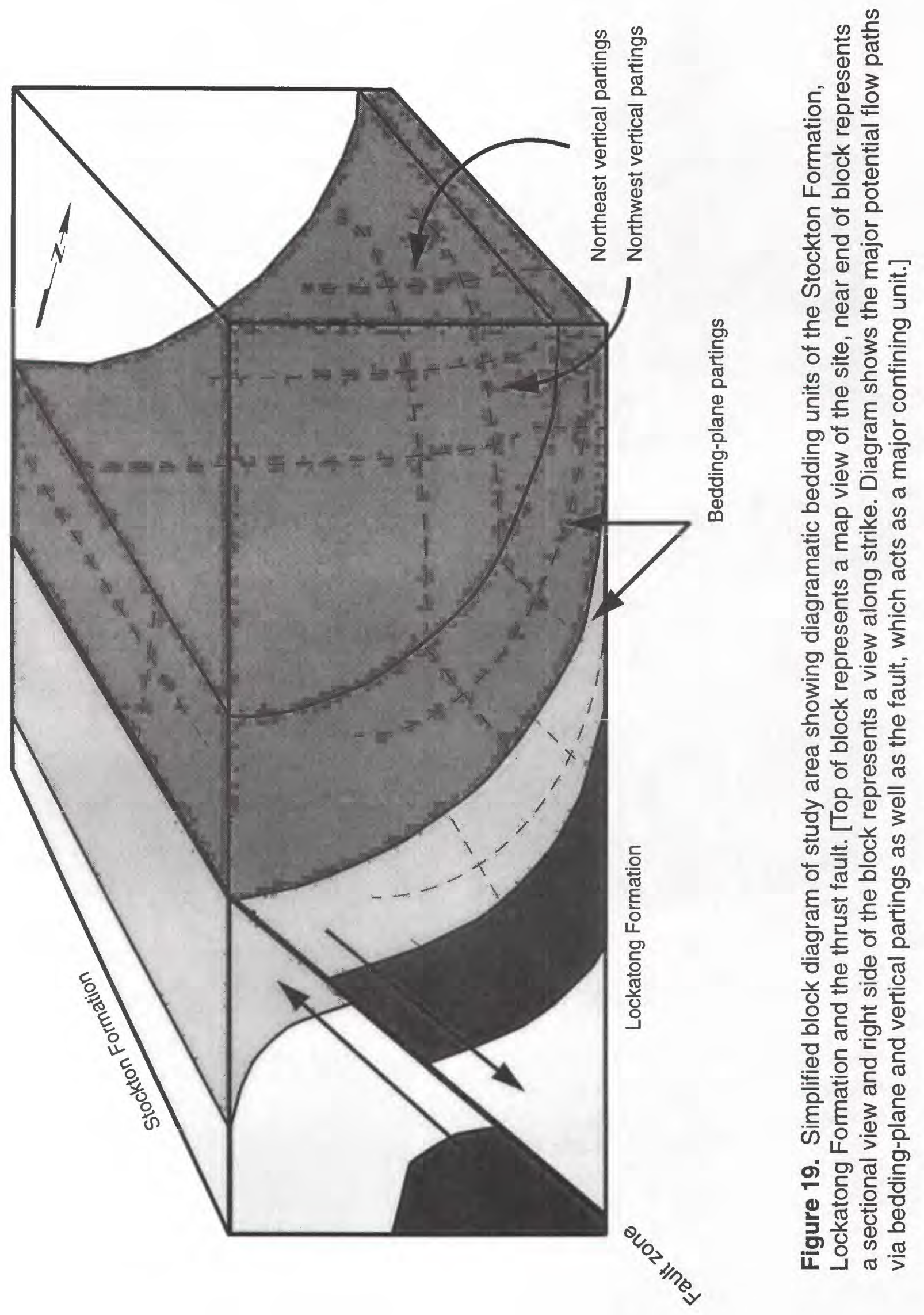




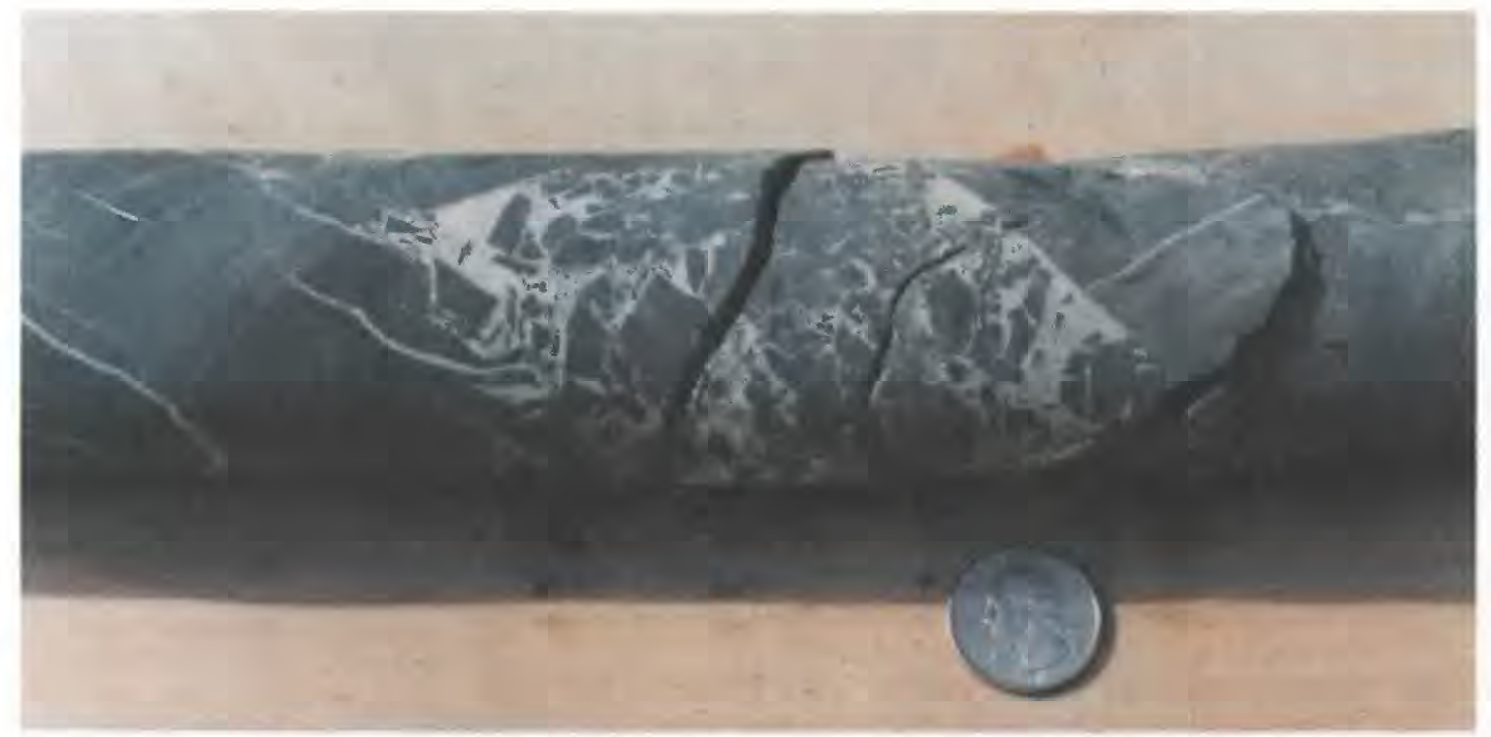

Figure 20. Rock core from well $42 B R$ at 68 feet below land surface showing steeply dipping beds on either side of brecciated and cemented fault zone. [Right side of photograph is nearer to land surface.]

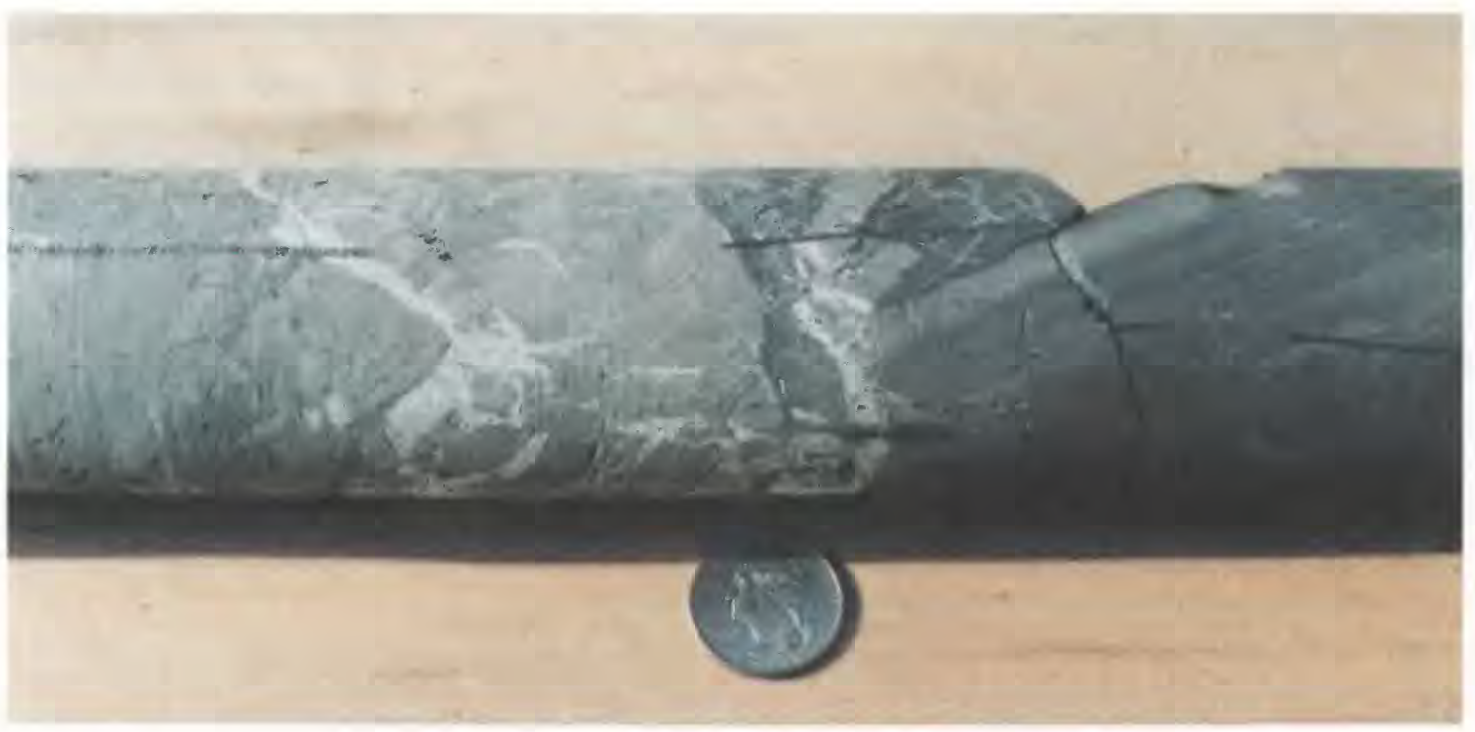

Figure 21. Rock core from well $42 B R$ at 111 feet below land surface showing steeply dipping beds and shallow dipping fault. (Fault zone shows brecciation and cementation. Fault is nearly perpendicular to the plain of the bedding). [Left side of photograph is nearer to land surface.] 


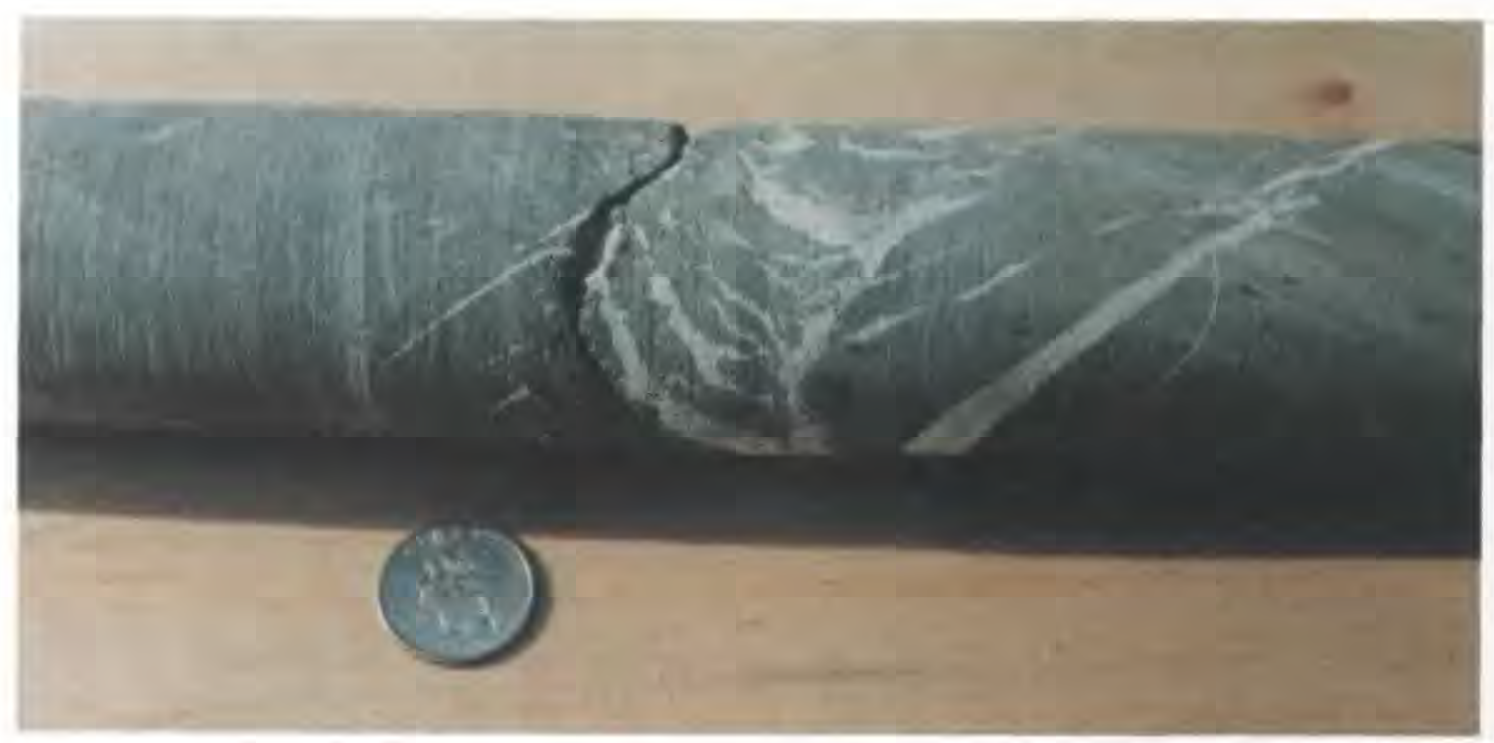

Figure 22. Rock core from well 42BR at 127 feet below land surface showing steeply dipping beds and brecciated in the fault zone. [Left side of photograph is nearer to land surface.]

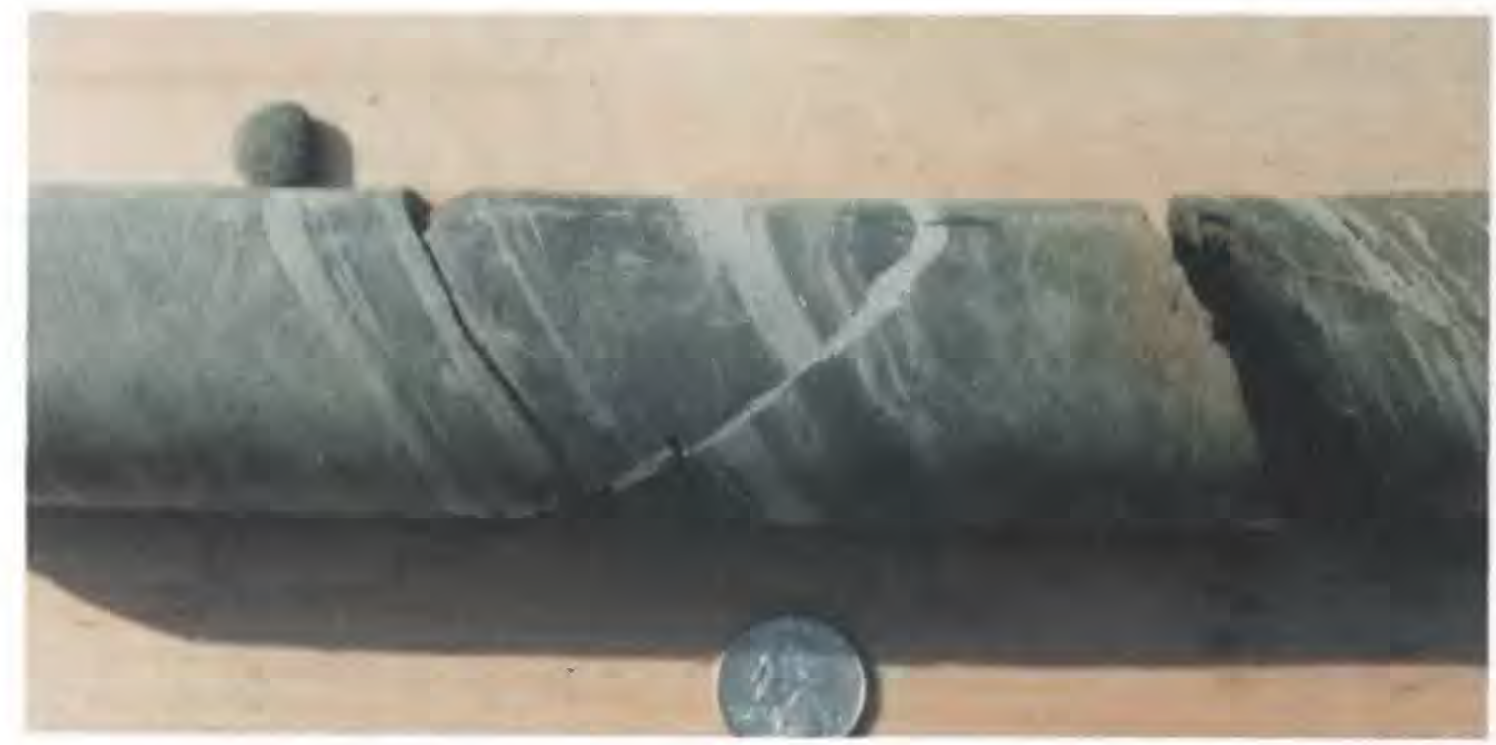

Figure 23. Rock core from well 17BR at 55 feet below land surface showing gently dipping beds and steeply dipping fault. ( Fault plane is nearly perpendicular to the bedding plane. Fault zone is cemented.) [Left side of photograph is nearer to land surface.] 


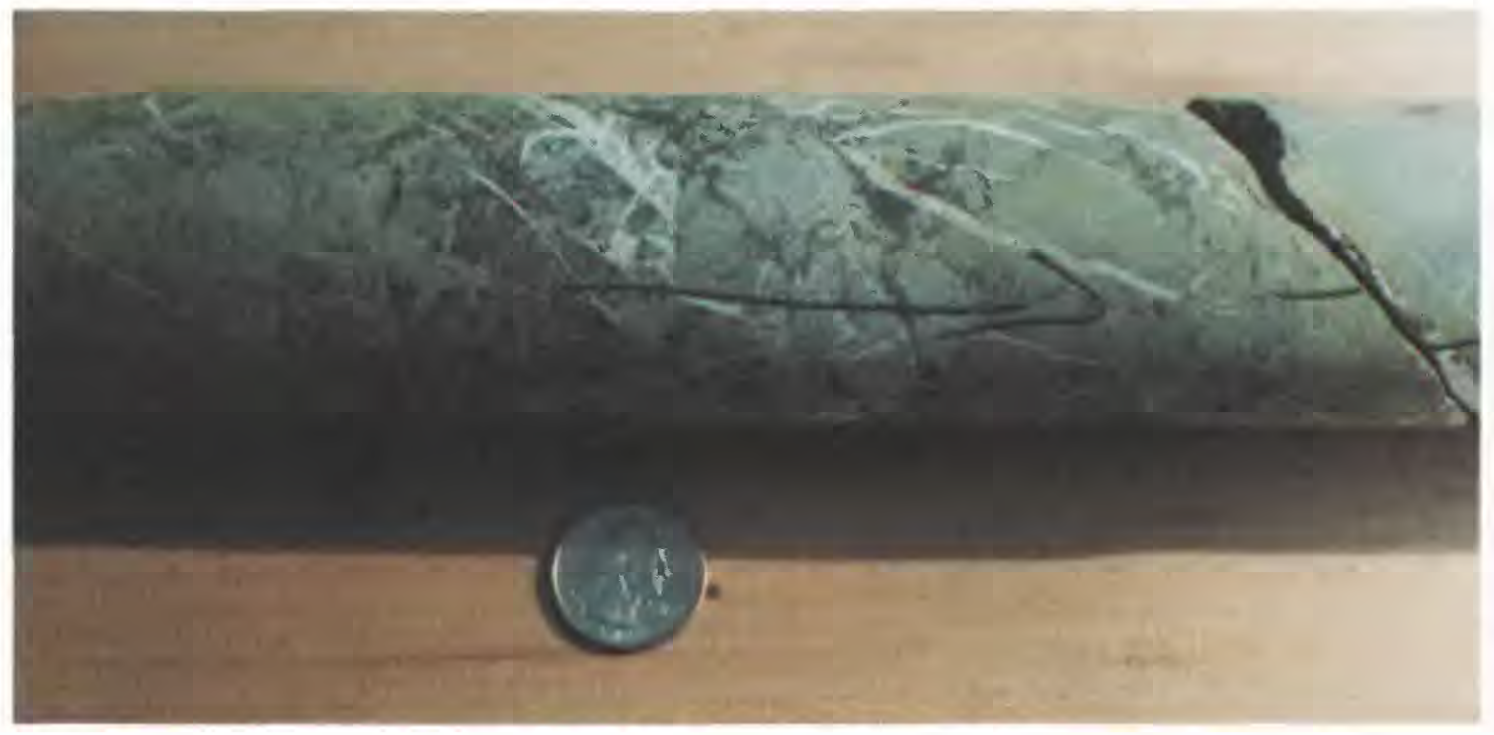

Figure 24. Rock core from well 51BR at 95 feet below land surface showing brecciation in fault zone. (Fault zone is cemented) [Left side of photograph is nearer to land surface.]

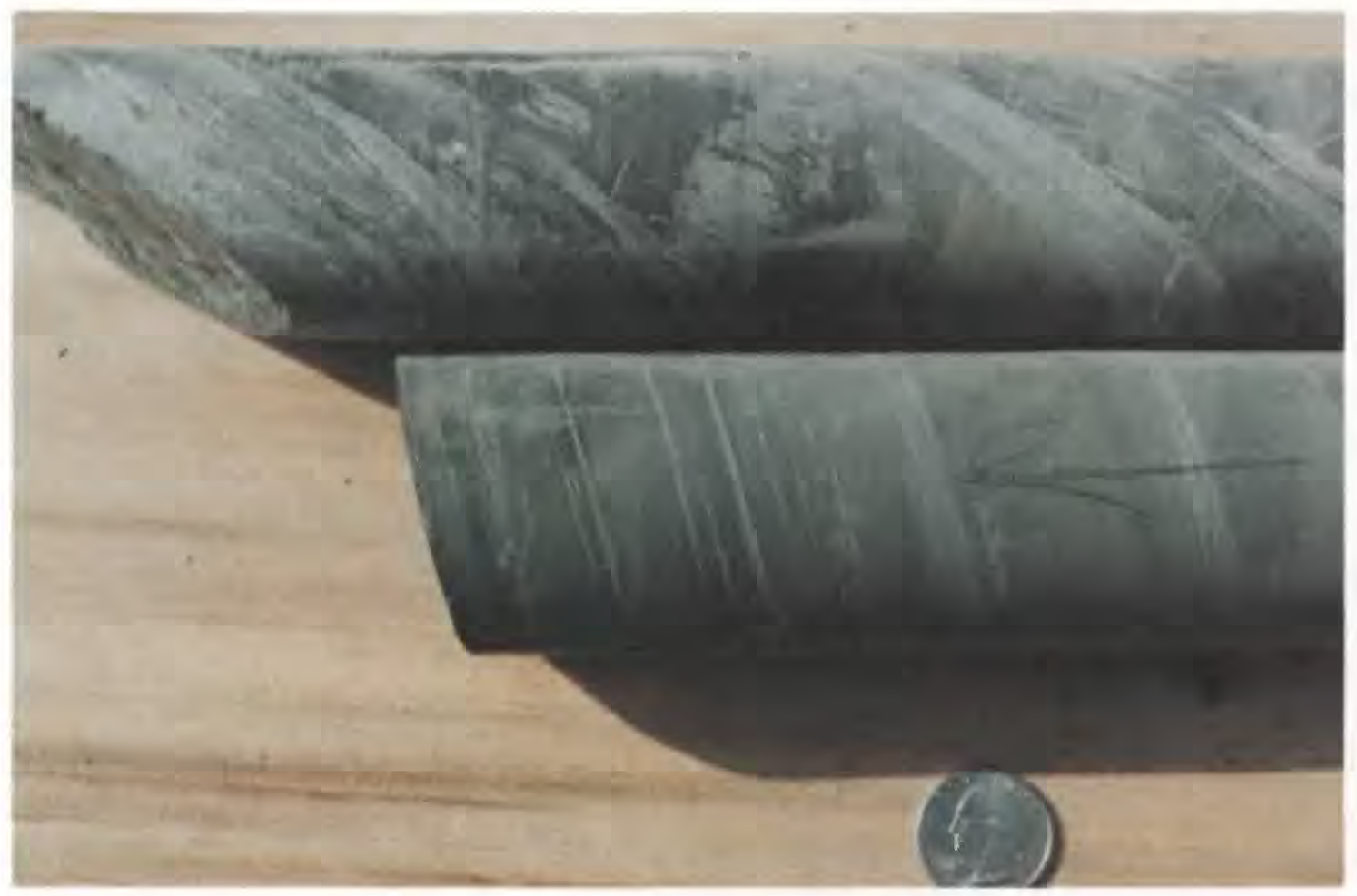

Figure 25. Rock core from well 42BR showing shallow dipping bedrock and well 43BR showing steeply dipping bedrock. [Left side of photograph is nearer to land surface.] 
(fig. 21) shows a 3-in fault contact. Bedrock above the fault consists of light gray mudstones; bedrock below the fault zone consists of dark gray mudstone. The strike and dip of the bedrock above and below the fault is $\mathrm{N} 65^{\circ} \mathrm{E}$ and $30^{\circ} \mathrm{NW}$, and the dip angle and direction of the fault is $40^{\circ}$ and $\mathrm{S} 20^{\circ} \mathrm{E}$; therefore, the fault is nearly perpendicular to the plane of the bedding. Rock core from a depth of $127 \mathrm{ft}$ below land surface (fig. 22) shows a 2 -in fault zone. Bedrock above and below the fault has a measured dip angle of about $70^{\circ}$ and an dip direction of $\mathrm{N} 20^{\circ} \mathrm{W}$. The measured dip angle of the fault is about $30^{\circ}$, and the dip direction is $S 10^{\circ} \mathrm{E}$. Again the fault plane is nearly perpendicular to the bedding.

In addition to these three examples of faulting at specific depth intervals in the core of 42BR, other examples are available.

Numerous other examples of faults are found at depths of 30 to $130 \mathrm{ft}$ below land surface in well 42BR. At the three depth zones noted above, the attitude of the fault is nearly perpendicular to the attitude of the bedding. Based on the data, the suite of southeast dipping faults described above form a fault zone that is about $100 \mathrm{ft}$ thick.

Offset bedding, fault brecciation, and slickensides also are found in rock cores from wells 17BR (fig. 23) and 51BR (fig. 24). The core from monitoring well 17BR shows the dip of the bedding is about $25^{\circ}$, and the dip of the fault is nearly perpendicular to the dip of the bedding. The core from well 51BR shows a brecciated zone that is 8 to 10 in. wide. Based on these and other cores that show faulting, the fault plane is typically perpendicular to the bedding plane and the strike of the two planes is offset by about $20^{\circ}$.

Indirect evidence of faulting is interpreted from monitoring wells 51BR, 48BR, 22BR, $5 \mathrm{BR}$, and 20BR. Typically, bedrock is fractured and pulverized in a fault zone, forming fault breccias and fault gouge. In the shallow environment, the fractured bedrock of the fault zone will chemically weather to form a thick clay zone. It was anticipated that competent bedrock would be encountered at these well sites at 10 to $20 \mathrm{ft}$ below land surface; however, competent bedrock was not encountered until 40 to $65 \mathrm{ft}$ below land surface, and drill cuttings from above the competent bedrock consisted of dry clay. Dry clay at a significant depth may result from weathering of the rock in a fault zone.

The fault is well located based on numerous rock cores from wells near buildings 40,21 , and 22. The fault in the Site 3 area is based on rock cores from wells 48BR and $51 \mathrm{BR}$ and is less well located. As a result of data from wells 48BR and 51BR, the strike direction of the fault changes from about $\mathrm{N} 60^{\circ} \mathrm{E}$ on the west side of the NAWC to about $\mathrm{N} 45^{\circ} \mathrm{E}$ on the east side of NAWC. The change in strike direction occurs near wells 31BR and 48BR. An alternative location of the fault in the eastern part of the NAWC is about $300 \mathrm{ft}$ south of where it crosses line A (fig. 8). T. is interpretation assumes that the strike of the fault does not change, and therefore, the fault zone near Site 3 could be as much as $200 \mathrm{ft}$ south of where it is plotted.

Analysis of static, drawdown, and stressed water levels shows that the fault zone acts as a confining unit and has a significantly lowe* capability to transmit water through it or within it than the bedding units. This may be because, in selected shallow areas and at $d$ spth the fault zone abruptly terminates bedding partings and vertical partings, thereby tern'inating the water-bearing zones. As a result of faulting and weathering, the fault zone eff $: c-$ tively separates ground-water flow in the rocks on the north side of the fault (the Lockatong aquifer) from ground-water flow in rocks on the south side of the fault (the Stockton aquifer). 


\section{Folds}

The rocks of the Lockatong Formation are folded into a synform, and rocks of the Stockton Formation are folded into an antiform (fig. 19). The general shape of the synform and antiform is based on the complementary interpretations of the natural gammaray anomalies and the dip angles as measured from the rock cores. The structure of the bedding based on the gamma-ray data shows a distinct synform on the north side of the fault. The bedrock dip in the core sections that were collected 200 to $300 \mathrm{ft}$ from the fault is similar to the regional dip that was measured in nearby outcrops.

Along Section E-E' (fig. 14) rock cores from well 42BR show that the bedding dips from $50^{\circ}$ to $70^{\circ}$, and rock cores from well 43BR show a bedding dip of about $25^{\circ}$ (fig. 25). The dip angles from 11 rock cores collected north of the fault are used to define the synform in the Lockatong formation. The dip angle from 3 rock cores and natural gamma-ray logs from 14 wells south of the fault are used to define the antiform in the Stockton Formation. The angle of dip for the beds in rock cores from wells 28BR (fig. 15) and $6 \mathrm{BR}$, and the shallowest part of well 42BR (fig. 14) were used to define the antiform in the Stockton Formation. All measured dip angles from each core are shown on the respective bedrock well in the geologic section A-A' to I-I' (figs. 10 to 18 ).

\section{Bedding-Plane and Vertical Partings}

In the bedding units of the Lockatong and Stockton Formation are a set of bedding-plane partings and two sets of vertical partings. The bedding-plane partings are laterally extensive and are interpreted to be the major waterbearing zones. The bedding-plane partings in the Lockatong Formation are typically planar and confined to a thin zone, whereas the bedding-plane partings of the Stockton
Formation are interconnected and form a wide zone.

The vertical or near vertical parting: are typically perpendicular to the bedding, although in some locations they are vert cal to land surface. The major set of vertical partings has a strike of about $N 50^{\circ} \mathrm{E}$, and the mir $\rightarrow r$ set has a strike of about $\mathrm{N} 20^{\circ} \mathrm{W}$. Vertical partings in large outcrops near the NAWC range in length from about $100 \mathrm{ft}$ to more than $200 \mathrm{ft}$; however, they are limited in height. A single vertical parting typically is confined to 1 to $5 \mathrm{ft}$ of bedding, although in some places, a single vertical parting may penetrate $10 \mathrm{ft}$ or more of bedding. The vertical partings in the sandstone-rich units are typically widely spaced, on the order of one parting per $2 . \mathrm{ft}$, whereas the vertical partings in the siltstones and mudstone are more closely space, al out five partings per foot.

The three sets of partings are wides vread in the bedrock, and they are the primary pathways for ground-water flow in the aquifers. A generalized block diagram of the Site 1 area shows the relative attitude of the bedding units and the fault as well as the orientation of bedding-plane partings and the two sets of vertical partings (fig. 19).

Regionally and at the NAWC, the partings become more transmissive or less transmissive as a result of chemical and physical weathering of the bedrock. Typically, strata in each bedding unit grade from a shallow zone of some weathering to a deeper zone of limited weathering. The shallow zone of some weathering is from land surface to 40 to $70 \mathrm{ft}$ deep. At depths greater than about $70 \mathrm{ft}$ below land surface, there is a deeper zone of limited weathering. In the shallow zone of some. weathering, a high concentration of small fractures is found in addition to the beddingplane and vertical partings, and many of the fractures are partially or completely fille $\mathrm{f}$ by mud and silt. Because of weathering in the shallow part of each unit (1) there are more 
ground-water flowpaths, (2) ground-water flow will not be as strongly controlled by the bedding partings, (3) ground water will have a tendency to flow more closely in the direction of the general ground-water-flow gradient, (4) shallow bedrock will have a higher storage capacity, and (5) the shallow parts of a bedding unit will show less drawdown than deeper parts of the same unit. Analysis of drawdown water levels from aquifer tests shows less drawdown in the shallow part of many of the bedrock units than in the deep part of the same units.

\section{SURFACE-WATER SYSTEM}

The regional surface-water system consists of the Delaware River about 2 miles west of NAWC, Gold Run and its tributaries, West Branch Shabakunk Creek and its tributaries, and an unnamed stream referred to in this report as Villa Victoria Brook, which passes through Villa Victoria School campus (fig. 6). In addition, a number of small springs are present.

\section{Delaware River, Streams, and Springs}

The Delaware River is the major river in the study area with an annual mean discharge at Trenton, N.J., of $11,660,000 \mathrm{ft}^{3} / \mathrm{s}$ for the period of record 1913-98. All ground-water and surface-water flow in the study area eventually discharges to the Delaware River. The headwaters for Villa Victoria Brook, Gold Run, and the West Branch Shabakunk Creek are near the NAWC, and start of flow for each stream is from springs in the Lockatong Formation. Generally each stream flows southward to cross over the fault/contact of the Lockatong and Stockton formations. Villa Victoria Brook originates in the Lockatong Formation and flows southwestward. Upon reaching the fault/contact the brook flows along the fault/contact to the Delaware River.
The headwaters of Gold Run start just north of the fault/contact as springs. Water from th ? springs flows in a stream channel to the fault/ contact. During periods of low flow, the stream loses water after it flows over the fault contact, and the channel becomes dry. The stream then reappears a few hundred feet down the channel. During periods of high flow, the channel contains flow along its whole length. The headwaters of West Branch Shabakunk Creek originate in three short tributaries, with start of flow that is north of the fault/cont ct. $^{\text {. }}$ The three tributaries join at the fault/contact. There are no other tributaries to the creek in the immediate study area or over the Stoc'ton Formation.

Three springs labeled Spring 1, Spring 2, and Spring 3 near the NAWC (fig. 6) generally flow year round. They can be dry during mid and late summer, however, when rainfall is limited and evapotranspiration is high. Spring 1 is on the west side of NAWC just north of the fault. Discharge measured in a Parshal flume ranged from 0 to about $75 \mathrm{gal} / \mathrm{min}$. During periods of medium and low flow, discharge from the spring flows for about $100 \mathrm{ft}$, then percolates back into the aquifer. During periods of high flow, water from the sprirs flows to a culvert then under Parkway Avenue.

Spring 2 on the east side of the $\mathrm{NAW}^{\prime} \mathrm{C}$ is in a forested area behind a commercial st ip mall. The spring discharge point is in an area that has been filled with rocks and other dobris. Farmers in the past tried to fill in the spring with rocks and other debris in an attempt to make the land more tillable. The original location of the spring may be in the wetlands about 500 feet north of where the spring is plotted in figure 6. As noted in the hydroseologic framework section, the exact location of the fault/contact in the east part of the farility is not well known; therefore, depending $~ r \eta$ the original location of Spring 2 the fault cortact could be about $500 \mathrm{ft}$ south of where it was plotted in figure 6. Attempts to measure 
discharge from the Spring 2 were unsuccessful. Discharge was visually estimated five times during 1987 at 0 to $0.1 \mathrm{ft}^{3} / \mathrm{s}$ ( 0 to 45 $\mathrm{gal} / \mathrm{min}$ ).

Spring 3, is immediately south of the circle at the Ewing Cemetery (fig. 6). The spring is believed to have originated in the cemetery because a spring is shown near there in the 1913 map (fig. 26). It is believed that water from the spring has been diverted to a culvert that carries the water to the south edge of the cemetery. Flow in the channel about 300 $\mathrm{ft}$ downstream from Spring 3 was measured twice. Both times flow was about $0.1 \mathrm{ft}^{3} / \mathrm{s}$ (about $45 \mathrm{gal} / \mathrm{min}$ ). At times during the mid and late summer, there has been no flow in the channel.

\section{West Branch of Gold Run}

The West Branch of Gold Run has not been described in previous studies. As a result, it is necessary to describe it in some detail. The start of flow in the West Branch of Gold Run is Spring 1. Flow from the spring travels down a small channel through forested wetland to a culvert at the intersection of Decou Avenue and Parkway Avenue. Upon entering the culvert the stream flows underneath Parkway Avenue. Together the West Branch of Gold Run and Parkway Avenue form the southern boundary of the NAWC. Because the stream is under the street, it is not visible except in some storm grates in Parkway Avenue and at its point of exit from the culvert on the south side of Parkway Avenue, east of the General Motors employee parking lot.

A 1913 map of West Trenton (New Jersey Department of Environmental Protection, 1913) (fig. 26) shows the West Branch of Gold Run flowed southeastward through a forested wetland west of the present NAWC property to Parkway Avenue. The stream then flowed eastward for about $700 \mathrm{ft}$ along the north side of Parkway Avenue. A few hundred feet west of the railroad trestle, the West Branch of Gold Run crossed under or over Parkway Avenue. The culvert or ford may have been about where the entrance gate to the NAWC is now located. Downstream from the culvert or ford, the West Branch of Gold Run flowed along the south side of Parkway Avenue under the railroad trestle to the confluence with the East Branch of Gold Run.

At present (1998), the stream still ficivs from Spring 1 southeastward toward Parkway Avenue, but now it enters a culvert system under Parkway Avenue. The "Plan and Profile of Parkway Avenue" maps (Mercer Courty Highway Department, 1942 map files) (f gs. $27 a$ and $b$ ) show the culvert system that $c$ ?ries the flow of the West Branch of Gold Run under Parkway Avenue. The culverts are engineered to carry the flow beneath Parkway Avenue and allow ground-water discharge to enter the culverts much the same way as the strear channel allowed ground water to enter the stream bottom. Reference location stations numbered 99 through 129 are shown on the highway maps and are used in this discussion. The stream flows into the culvert at the northwestern corner of the intersection of Parkway Avenue and Decou Avenue (station 128+50). The culvert carries flow under Parkway Avenue eastward about 2,900 ft to an exit culvert (station 100+20) east of the Gene-al Motor parking lots and west of a unused field owned by General Motors. At this location, the exit point of the culvert, the West Branch of Gold Run is visible as a permanent surfacewater stream. Construction diagrams of the culvert under Parkway Avenue show that the section from the inflow culvert at Decou Avenue eastward to station $127+50$ consists of 24 -inch vitreous clay pipe. At station $127+50$, the culvert carrying the West Branch of Gold Run joins a stormwater runoff culvert that

\footnotetext{
${ }^{3}$ Surveying notation to define a location that is $50 \mathrm{ft}$ past station 128.
} 


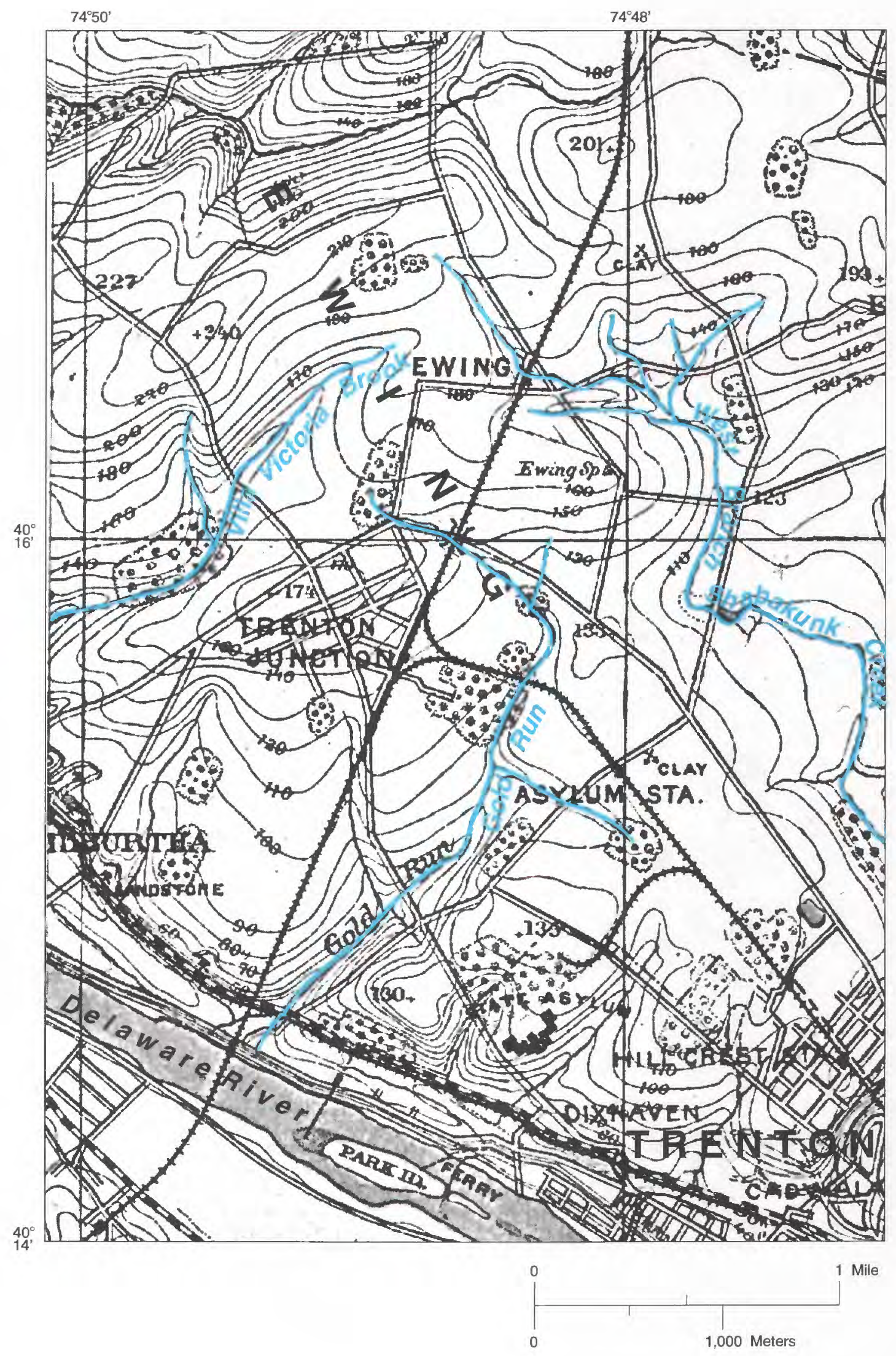

Figure 26. Map from 1913 showing the original channels of Gold Run. (From New Jersey, Geological Survey, 1913) 


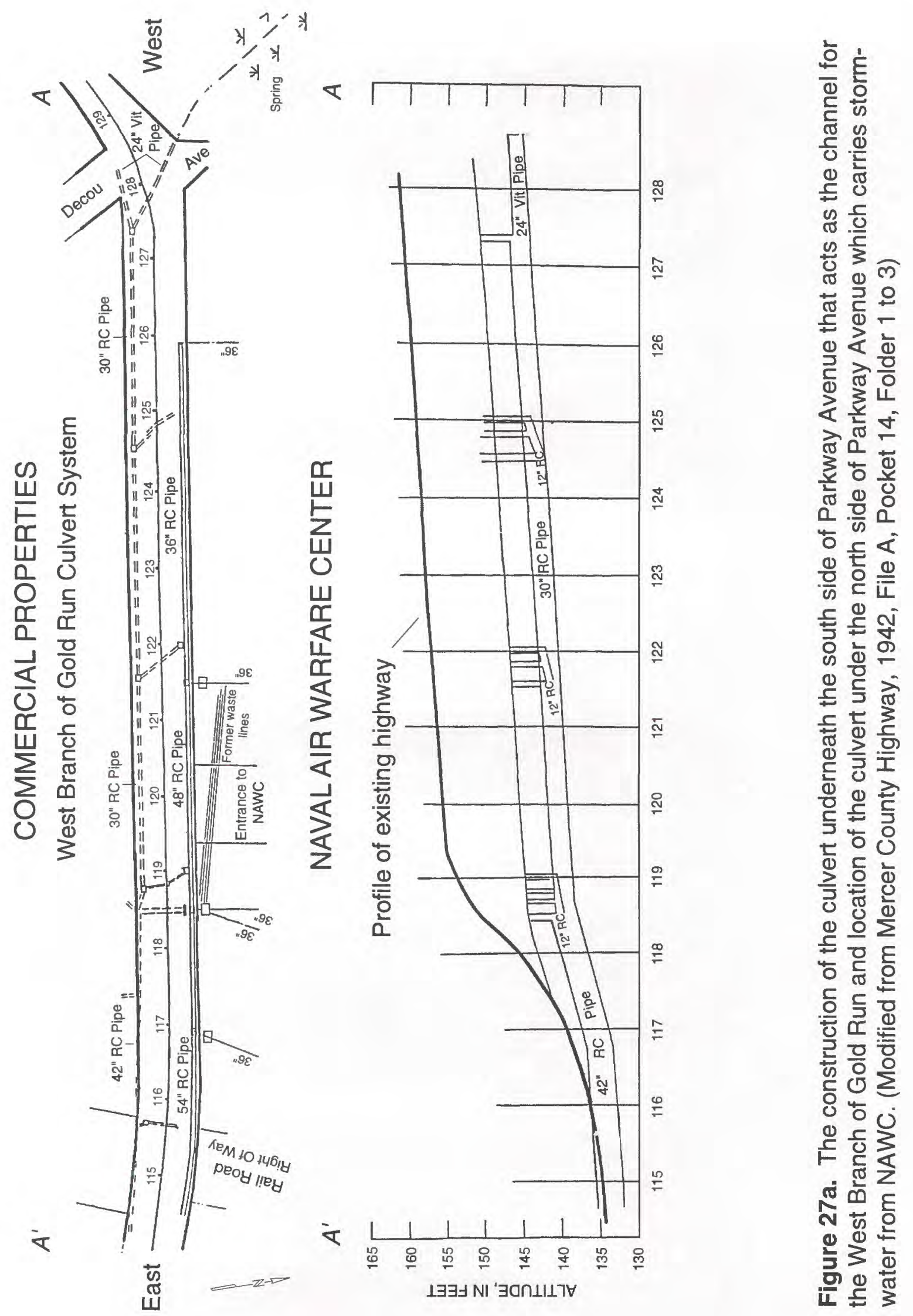




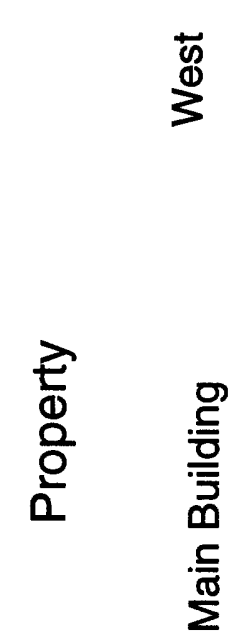

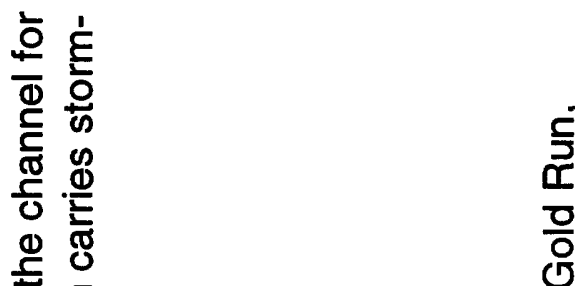

\&

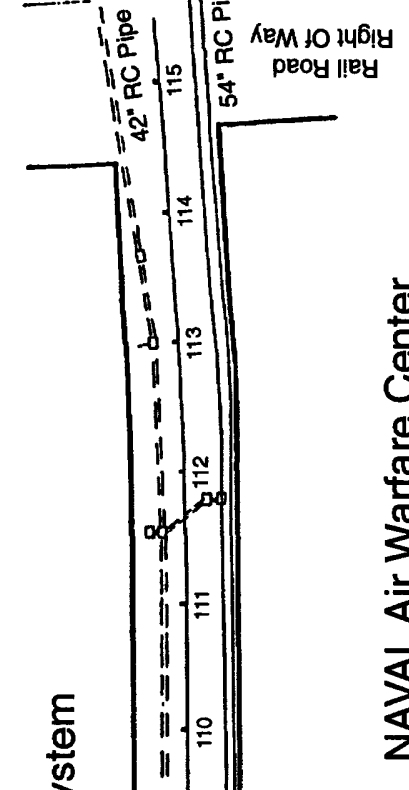

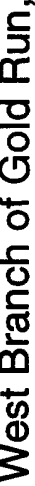

ปั

훙 운

®

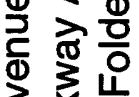

文紊

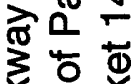

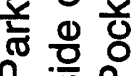

믐음

ť

离 응 $\frac{0}{\mathrm{i}}$

$\frac{0}{2}$

声 计

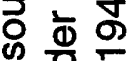

ఏ

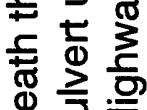

뜯 음

市衣 롱

능 응 엉

๑ 으

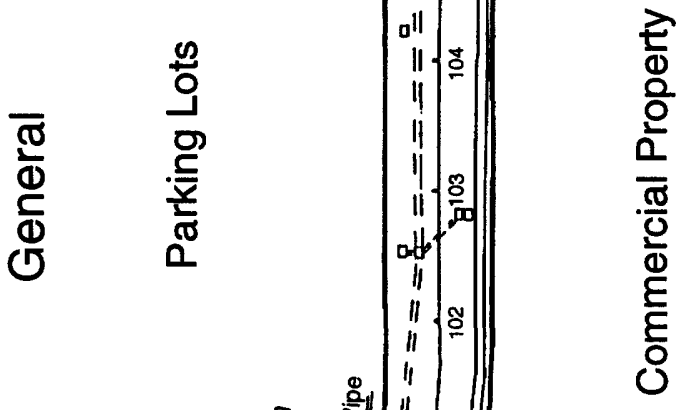

흥 은

을 동 웅

는 응 은

엉 论

동

ค ต

호옹

인

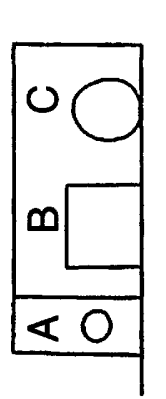

ตี

흠

$\sum_{0}$

交

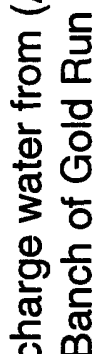

흠

䒕

छ

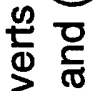

O

商交

ఏ

든

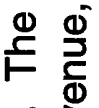

ن 文

N

온 音 
carries water under Parkway Avenue from streets west of Decou Avenue. From station $127+50$ to station $118+50$, the culvert is made of 30 -inch reinforced concrete pipe; from station $118+50$ to station $114+50$, the culvert is made of 42-inch reinforced concrete; and from station $114+50$ to station $100+20$, the culvert is described as a $3 \mathrm{ft}$ by $4 \mathrm{ft}$ flume.

The vitreous clay and reinforced concrete pipe culvert in 4- to 12-ft long pieces and are laid end to end with no cement in the joints. Therefore, the joints are about 4 to $12 \mathrm{ft}$ apart. Based on the construction details and road building technology, the design of the culvert allows ground water to enter and exit the culvert at each joint. The construction methods used in building this culvert allow the culvert to act similarly to the former streambed thereby allowing interaction of ground water and surface water.

The culvert where the West Branch of Gold Run emerges from beneath Parkway Avenue was visited more than 20 times during 1996-97. Flow was always observed exiting from the culvert pipe.

Three discharge culverts are visible when looking upstream to where Gold Run exits from under Parkway Avenue (fig. 27c inset). From west to east the culverts are labeled (A) GM property, (B) West Branch and the NAWC, and (C) East Branch. Culvert A (fig. $27 \mathrm{c}$ ) is a stormwater runoff culvert from General Motors parking lots. During visits to the culvert in 1996-97, flow was seen exiting culvert A during and after heavy rainfall, but there was light or no flow from culvert $A$ during periods of no precipitation. Culvert $B$ (fig. 27c) carries discharge water from both of the culvert systems that are under Parkway Avenue. The culvert system under the south side of Parkway Avenue was designed to replicate the ground-water/surface-water interaction of the West Branch of Gold Run as described above. In addition, the culvert on the south side of Parkway Avenue carries storm- water run-off from Parkway Avenue and from all commercial properties, except General Motors, and from all residential properties along of Parkway Avenue from Sullivan Way to Gold Run. The culvert system under the north side of Parkway Avenue carries stc "mwater runoff from the NAWC. The culve't system originates on the NAWC property' as a network of small culverts that discharge into one of four stormwater culverts. The fou " 36inch diameter culverts discharge water to the culvert that lies under the north side of Parkway Avenue. Stormwater from NAV'C property is kept separate from the West B-anch of Gold Run culvert system until about $50 \mathrm{ft}$ upstream from culvert B. Culvert C is the East Branch of Gold Run which carries storm vater runoff from the commercial, recreational, and wooded properties on either side of the East Branch of Gold Run.

Discharge at each exit culvert and at the main stem of Gold Run is shown in table 2. The discharge measurements were made on August 20, 1996, and September 4, 1997. Discharge on August 20, 1996, was about $1 \mathrm{gal} / \mathrm{min}$ from culvert $\mathrm{A}$, about $30 \mathrm{gal} / \mathrm{min}$ from culvert $B$ and $9.5 \mathrm{gal} / \mathrm{min}$ from culvert $C$. On September 4, 1997, however, culvert A and $\mathrm{C}$ were dry, whereas culvert $\mathrm{B}$ showed a discharge of about $90 \mathrm{gal} / \mathrm{min}$. It is not certain why culvert $A$ and $C$ showed no flow during September 4, 1997, while culvert B was flowing nearly 10 times the rate of the previous measurement.

Precipitation data for the 3 days pric to each discharge measurement are shown in table 3 . About 0.11 to 0.20 in of precipitation fell during the 48 hours prior to stream discharge measurements on September 4, 1997. The discharge resulted in a three-fold increase in discharge from the West Brar $h$ of Gold Run.

NAWC covers about 60 acres and more than 75 percent of it is covered with impormeable surfaces such as macadam, cement, or 
Table 2. Individual and total discharge from three culverts at the exit of the Gold Run tributaries from under Parkway Avenue

\begin{tabular}{rcccc}
\hline Date & GM Pipe (A) & NAWC Pipe (B) & $\begin{array}{c}\text { West Branch \& } \\
\text { East Branch (C) }\end{array}$ & Total \\
\hline \multicolumn{5}{c}{ [Discharge in cubic feet per second] } \\
$8-20-96$ & 0.0025 & 0.0665 & 0.021 & 0.090 \\
$9-04-97$ & dry & 0.203 & dry & 0.203 \\
& & [Discharge in gallons per minute] & & \\
$8-20-96$ & 1.122 & 29.85 & 9.42 & 40.39 \\
$9-04-97$ & dry & 91.11 & dry & 91.11 \\
\hline
\end{tabular}

Table 3. Precipitation at stations at Trenton State College (College of New Jersey) and Washington Crossing State Park during the day of stream gaging and the three previous days

[Precipitation, in inches]

\begin{tabular}{ccc}
\hline Date & Trenton State College & $\begin{array}{c}\text { Washington Crossing State } \\
\text { Park }\end{array}$ \\
\hline $8-20-96$ & 0.00 & 0.00 \\
$8-19-96$ & 0.00 & 0.00 \\
$8-18-96$ & 0.00 & 0.00 \\
$8-17-96$ & 0.00 & 0.00 \\
$9-04-97$ & 0.10 & 0.00 \\
$9-03-97$ & 0.10 & 0.11 \\
$9-02-97$ & 0.00 & 0.00 \\
$9-01-97$ & 0.00 & 0.00 \\
\hline
\end{tabular}


buildings. A rainfall of $0.1 \mathrm{in} / \mathrm{d}$ falling on an estimated 45 acres of impermeable surface would create a surface-water discharge increase of $85 \mathrm{gal} / \mathrm{min}$ in Gold Run if (1) rainfall were spread out over a full day, (2) if all rainfall discharged as overland flow to the stormwater runoff from the U.S. Navy NAWC, and (3) no precipitation evaporated or percolated into the ground.

\section{GROUND-WATER LEVELS}

This section includes static water-level data, drawdown water-level data, and stressed water-level data. Static water levels were collected during 1993-96 prior to the start up of the recovery well for the contaminated ground-water pump and treat facility. Drawdown water levels were collected during 1993-96 during each of three aquifer tests. Stressed water levels were collected at various times since the start of the pump and treat operation; however, only during August 25-27, 1997, were water-level data collected for all wells at the NAWC.

\section{Static Water Levels}

The USGS plotted and contoured the static ground-water levels in the fractured bedrock aquifer on maps and sections (figs. 28 to 38). The static water-level data presented here were collected December 4-5, 1995, prior to the start-up of the pump and treat facility.

The hydraulic gradient and ground-water flowpaths are controlled by many aspects of the hydrogeologic framework. The hydrogeologic framework includes strike, dip, and conductivities of the water-bearing zones, semi-confining zones, and fault plane/ confining unit, as well as the topography of the small valley, and location of and flow in the West Branch of Gold Run.

Hydraulic factors acting on the static water levels are the location of nearby ard distant recharge areas and discharge area" for the bedding units, and the screen interval of the monitoring well. The primary recharge area for each bedding unit is the outcrop area of the bedding unit provided the outcrop area is not in a wetland. The nearest bedrock discharge area for the NAWC facility is the spring and stream channel at the head of the West Branch of Gold Run. Distant bedrock discharge areas for the site 1 and site 3 areas of NAWC in clude the Delaware River and Villa Victoria Brook. The water level in a particular well is primarily controlled by the water level in the outcrop area of the bedding unit that contributes water to the screen interval of the well.

The static water-levels maps show projected water-level contours on a horizontal plane at an altitude of $+150 \mathrm{ft}$, which is approximately land surface (fig. 28), and at an altitude of $+50 \mathrm{ft}$, which is approximately 100 $\mathrm{ft}$ below land surface (fig. 29). On the north side of the fault, the water-level contours indicate that the hydraulic gradient is gen?rally southward at an altitude of $150 \mathrm{ft}$ (fig. $2 \varepsilon$ ) and radially toward bedding unit L-15 and L-16 at an altitude of $+50 \mathrm{ft}$ (fig. 29). However, as discussed in the methods section, the flowpath direction may be different than the hydraulicgradient direction. The predominate flow ath is in the water-bearing zones of each bedding unit from an area of recharge to an area of discharge (fig. 4). Therefore, the flowpath direction is westward in each bedding unit from the upland areas to spring Spl and the headwaters of the West Branch of Gold P un.

Static water-level contour lines in sentions A-A' through I-I' (figs. 30 to 38 ) show that the hydraulic gradient north of the fault/contact is generally downward and southward, but along the fault/contact, the hydraulic gradient is upward and northward. Again the flowpeth is predominantly within the water-bearing zones of the bedding units, and it is interpreted that the flowpath north of the fault is into the page 


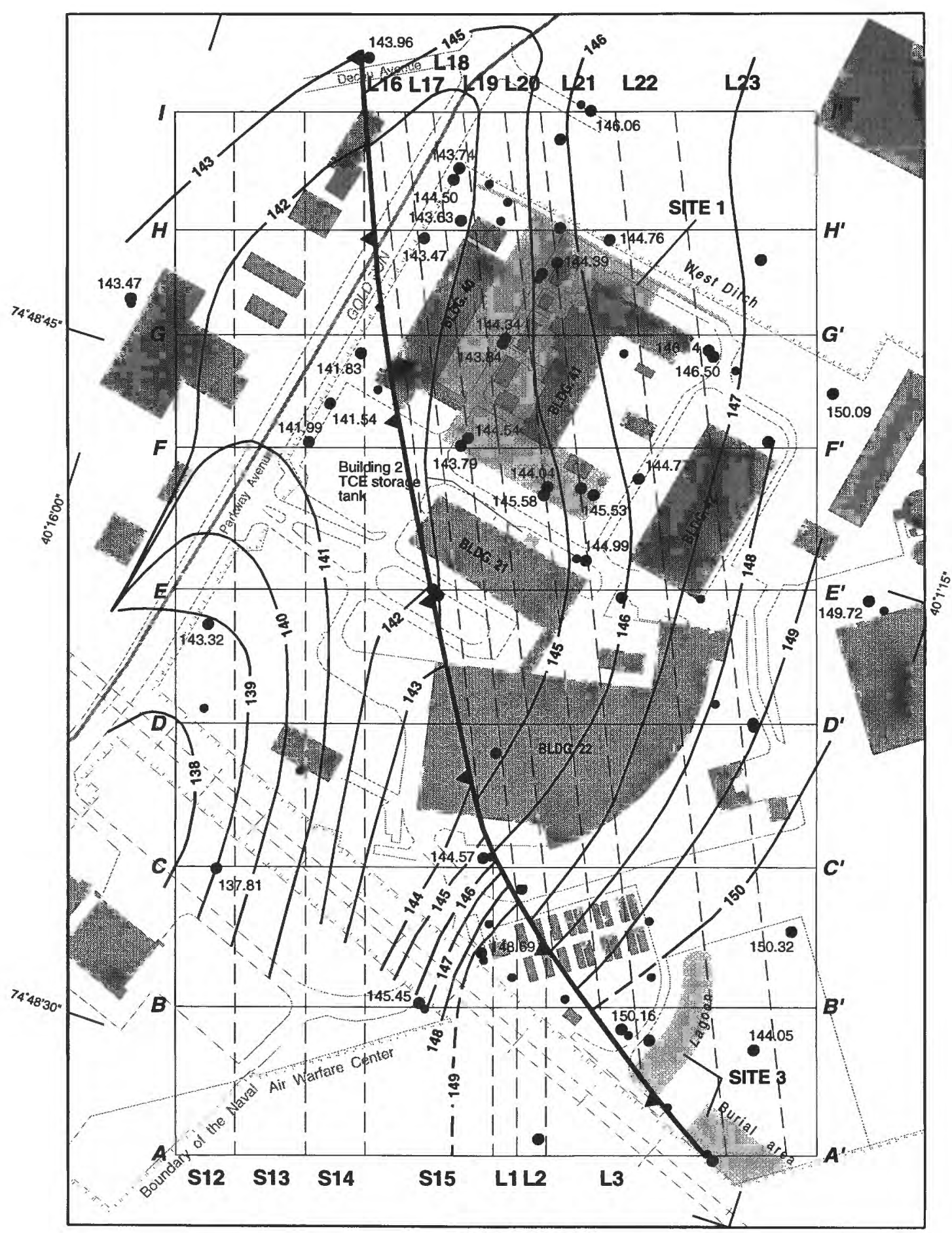

EXPLANATION

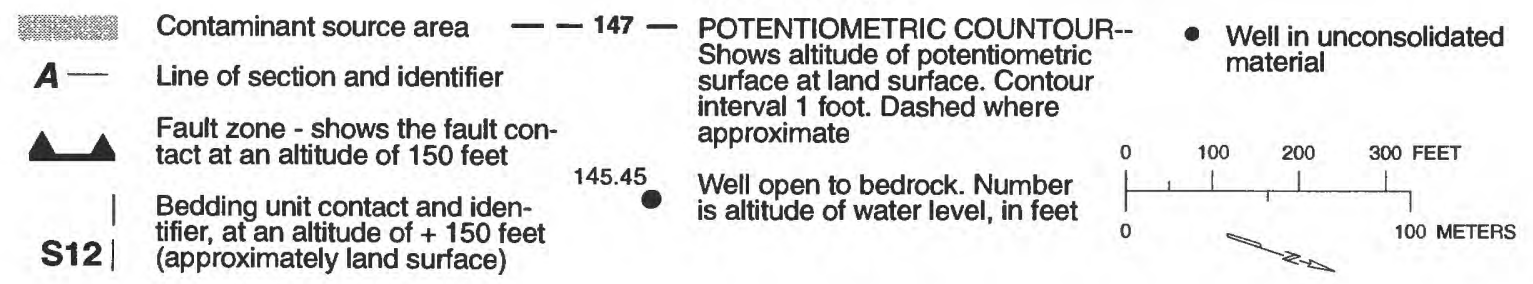

Figure 28. The static potentiometric surface at an altitude of +150 feet, (approximately land surface) December 4, 1995, Naval Air Warfare Center, West Trenton, N.J. 


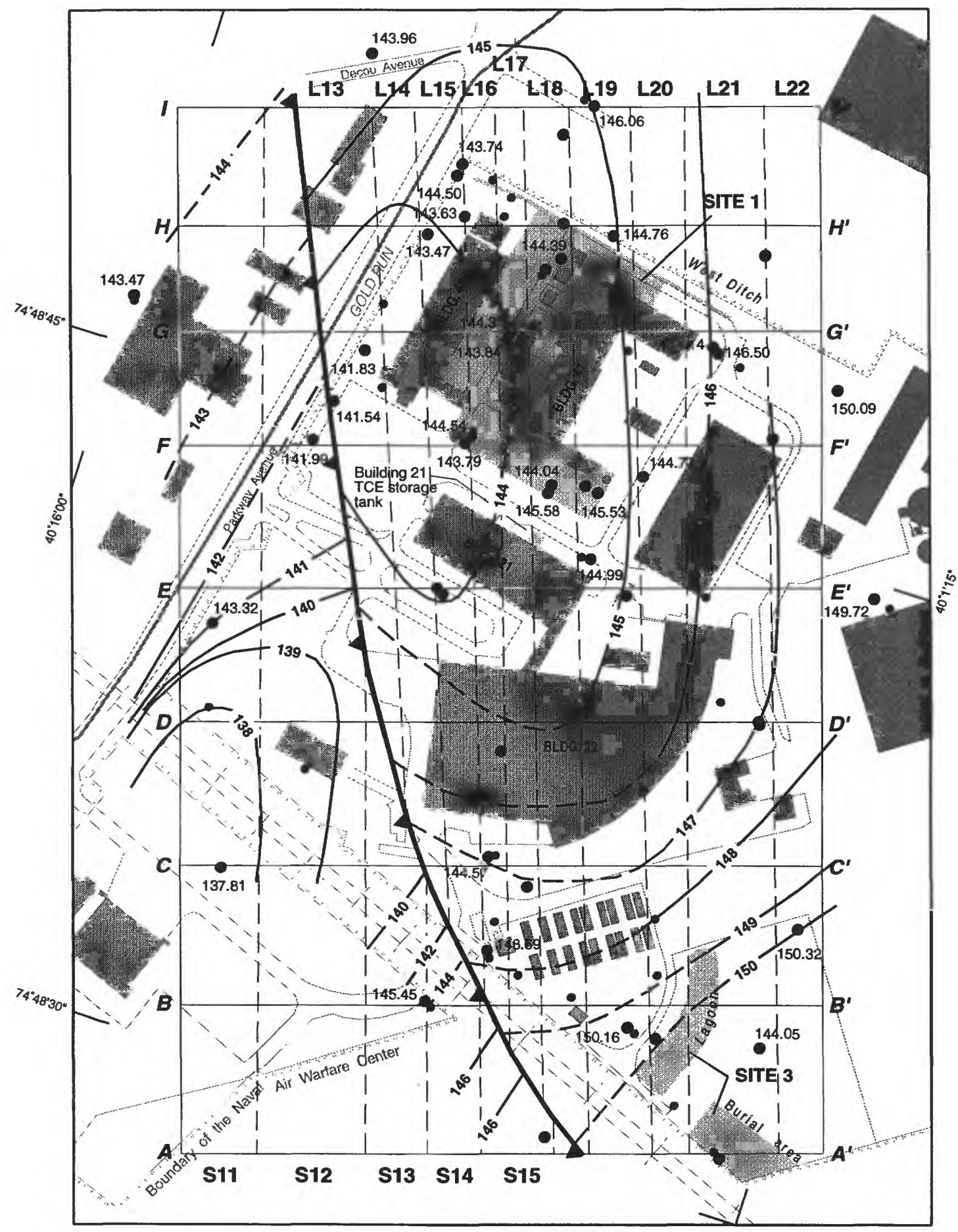

EXPLANATION

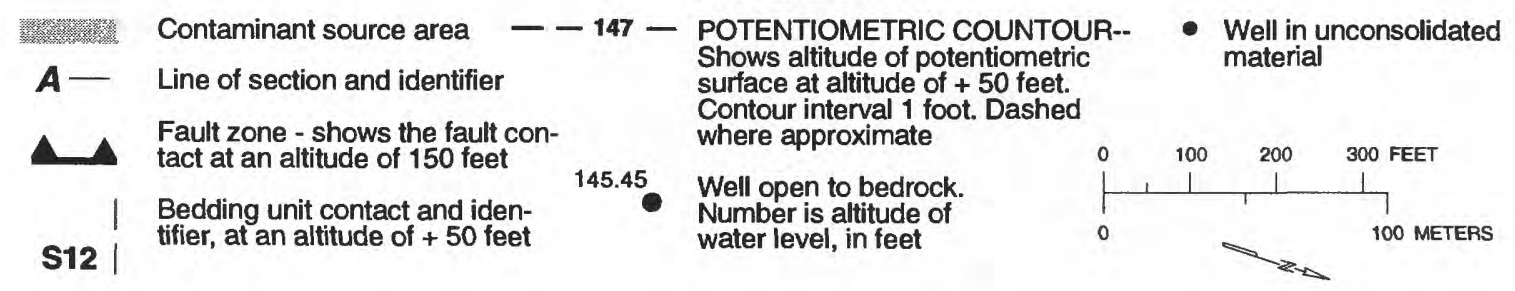

Figure 29. The static potentiometric surface at an altitude of +50 feet, (approximately 100 feet below land surface), December 4, 1995, Naval Air Warfare Center, West Trenton, N.J. 


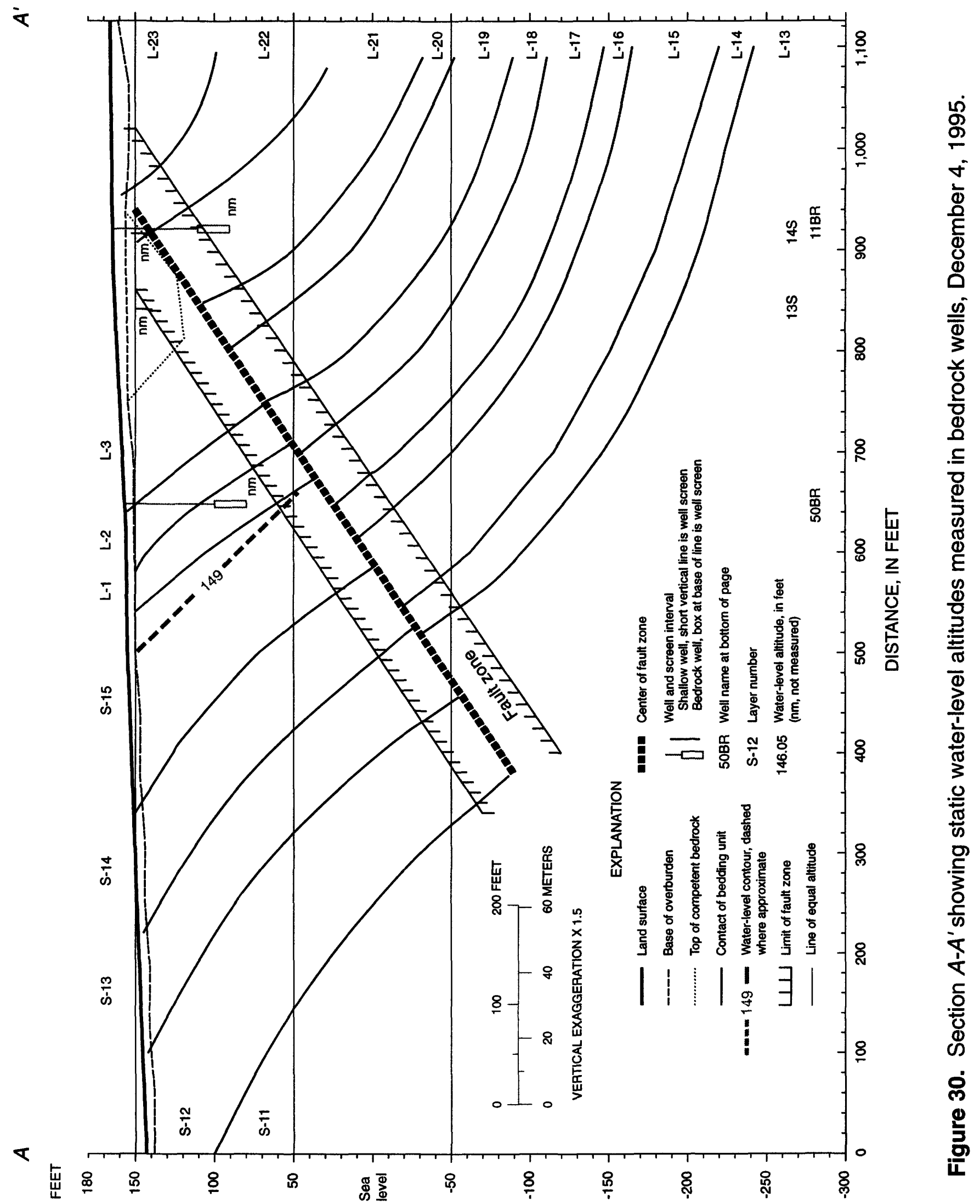


in

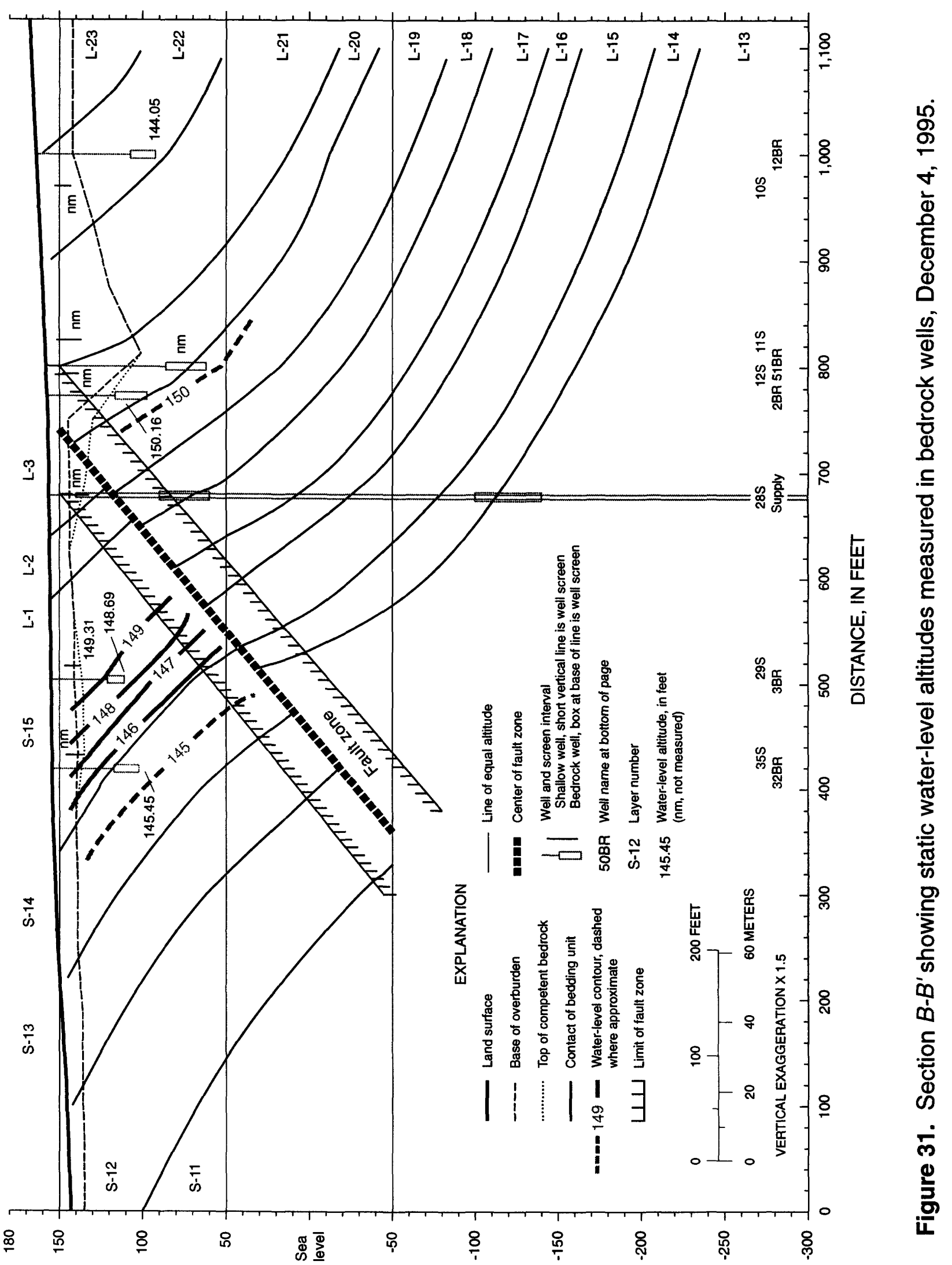




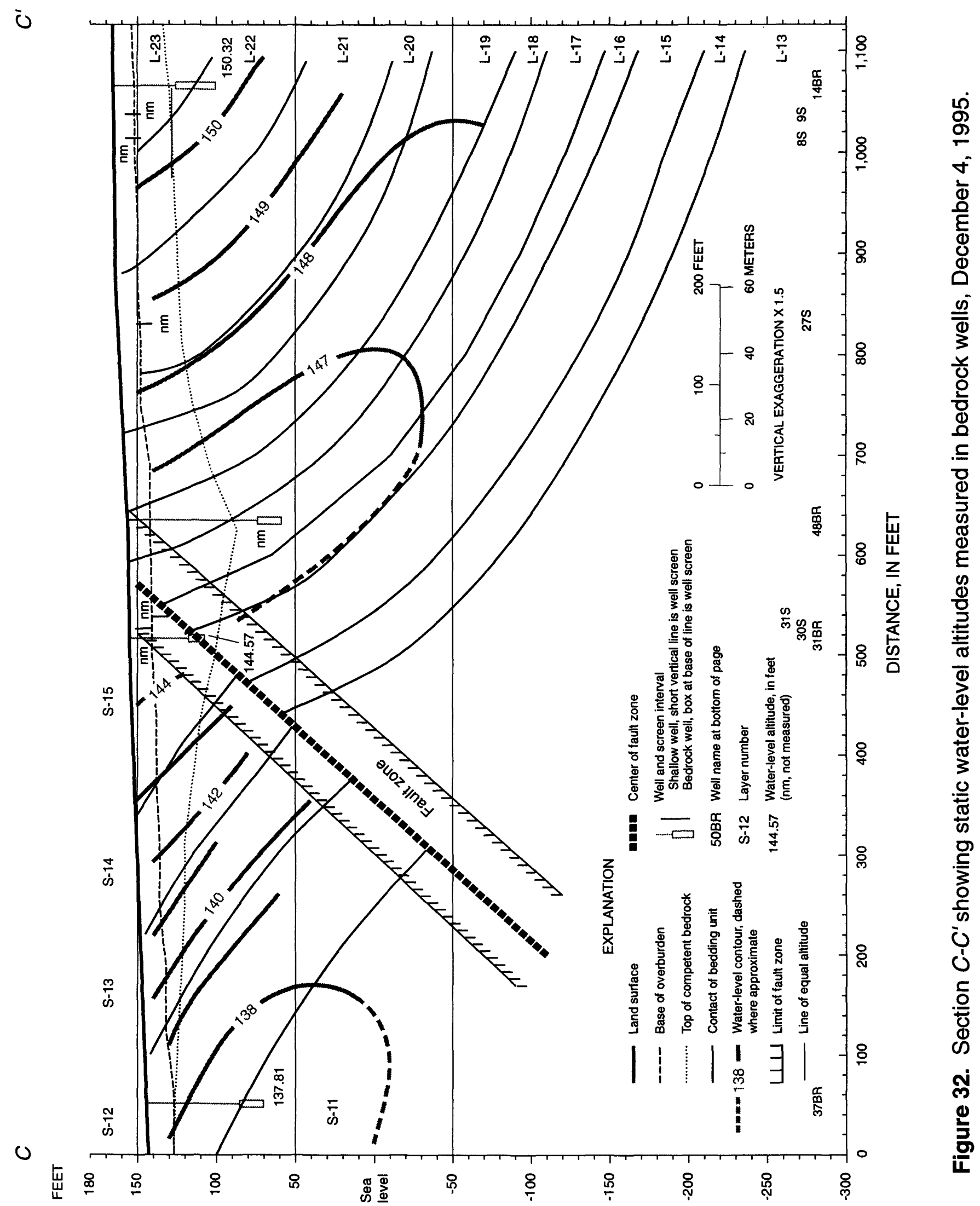


o

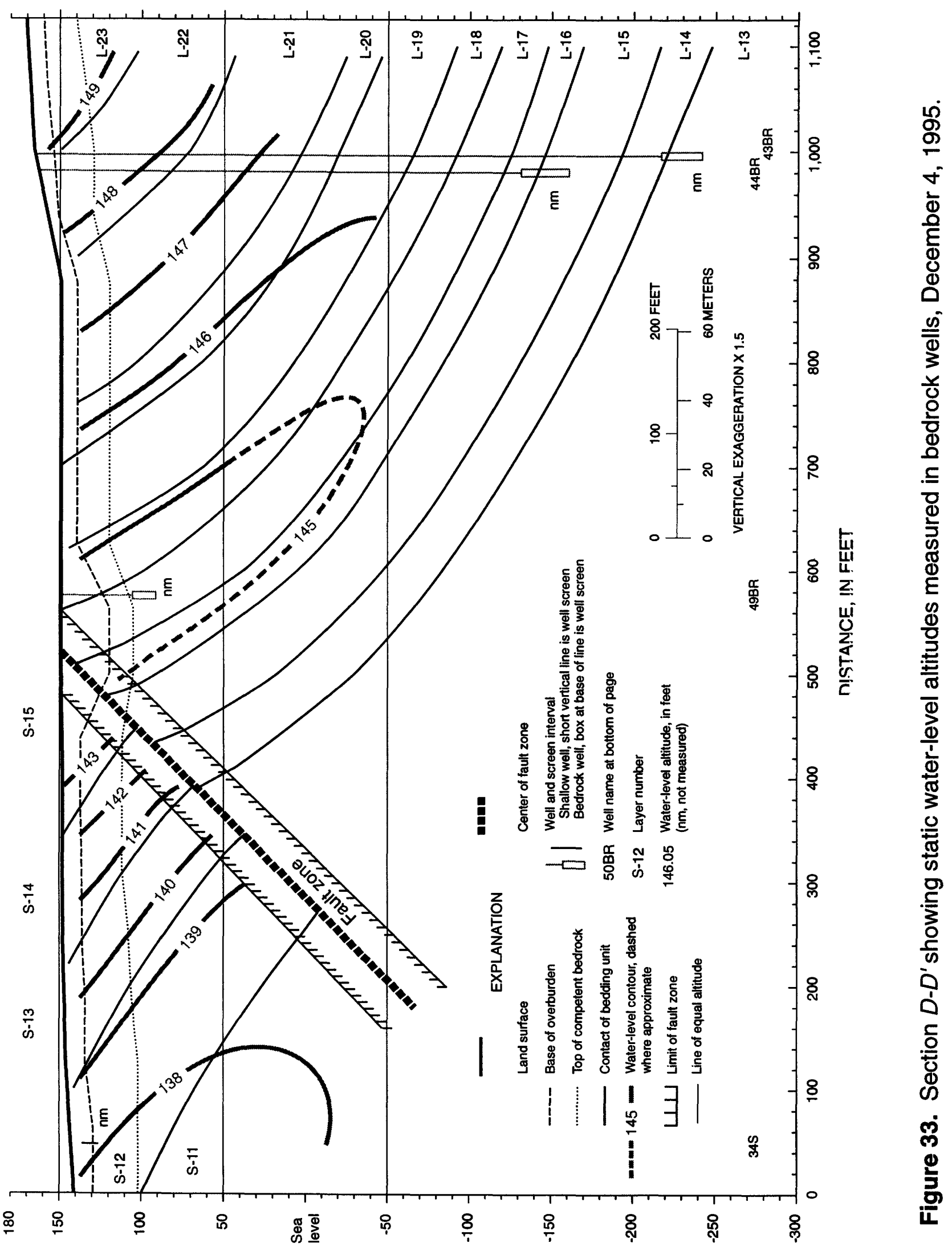


U

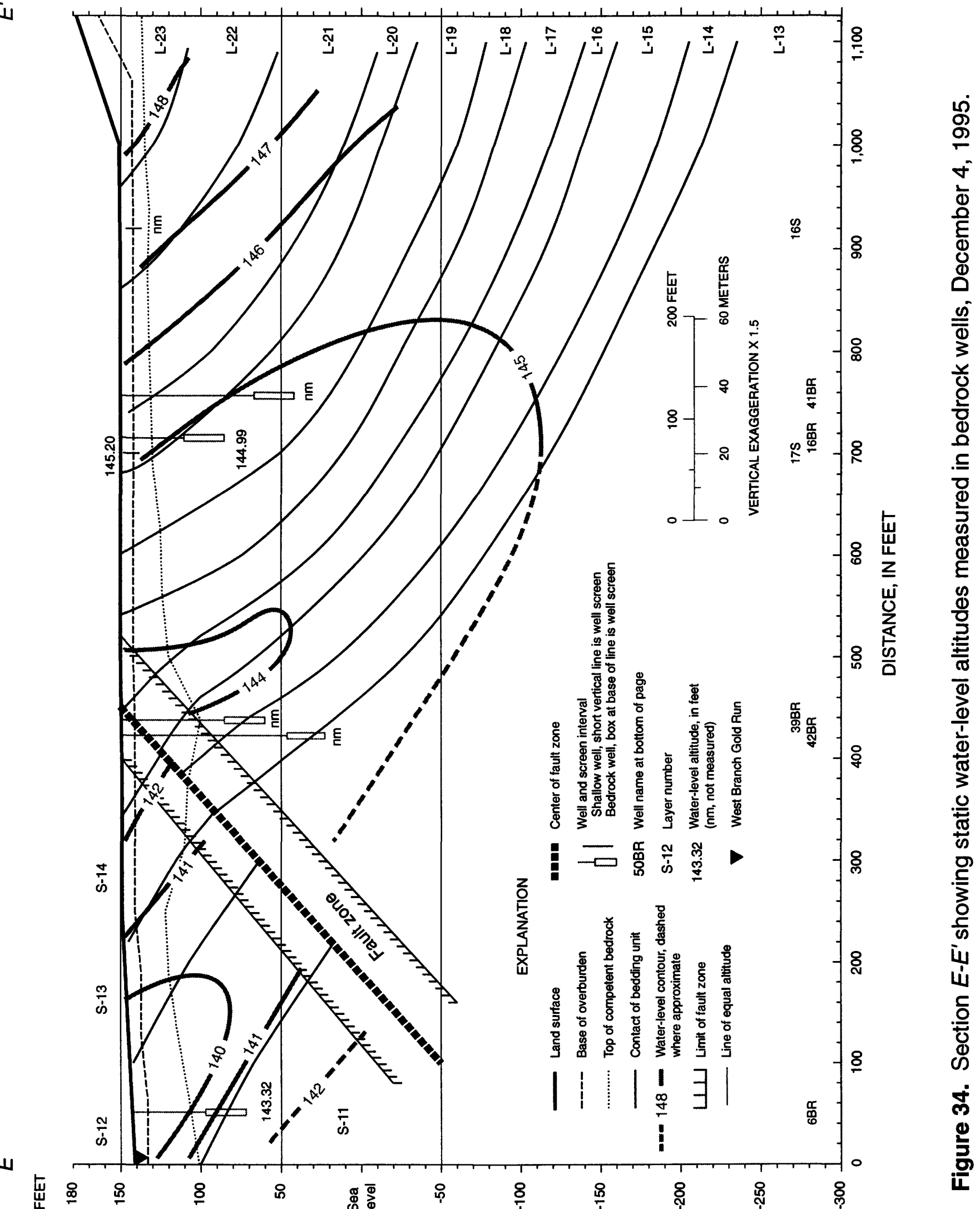




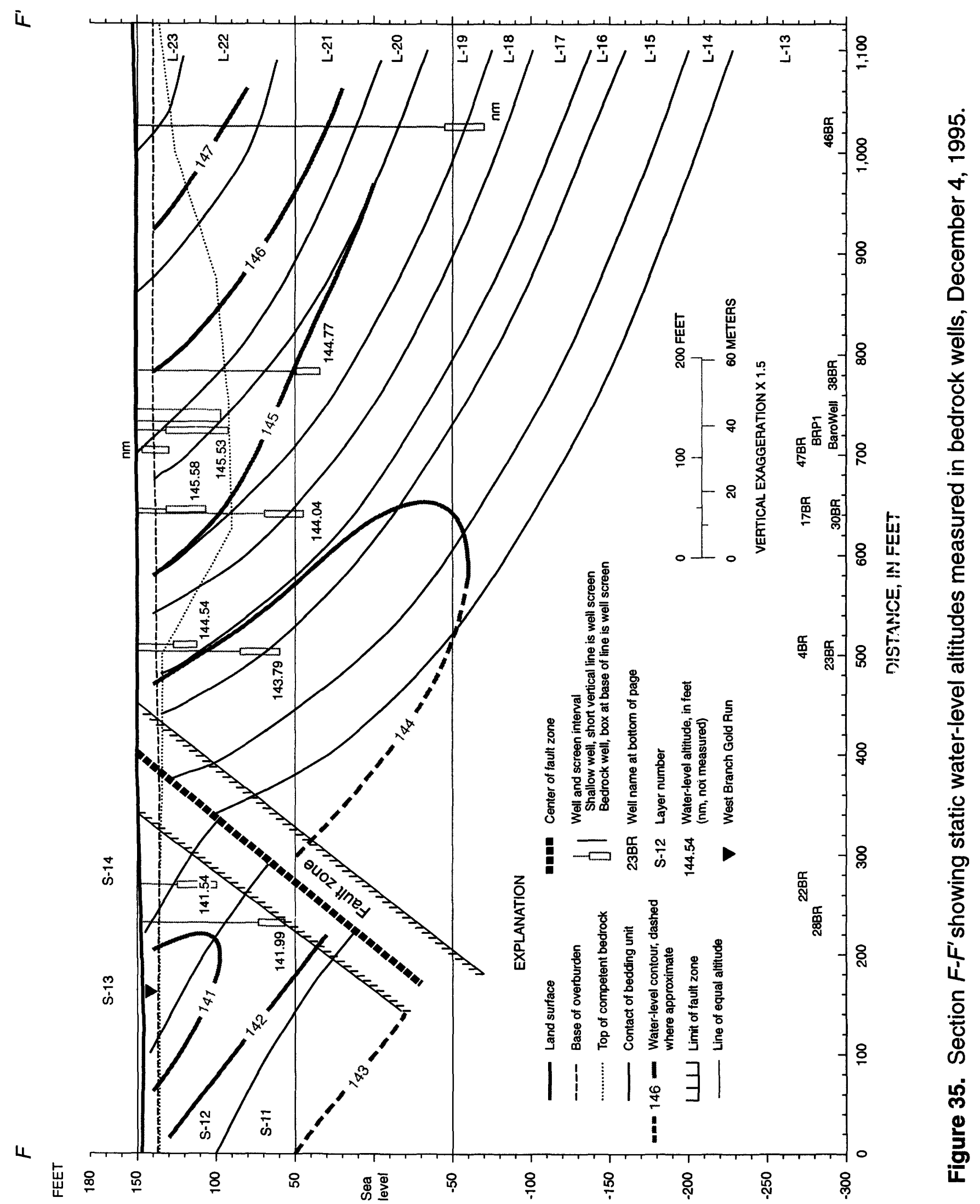


ర̄

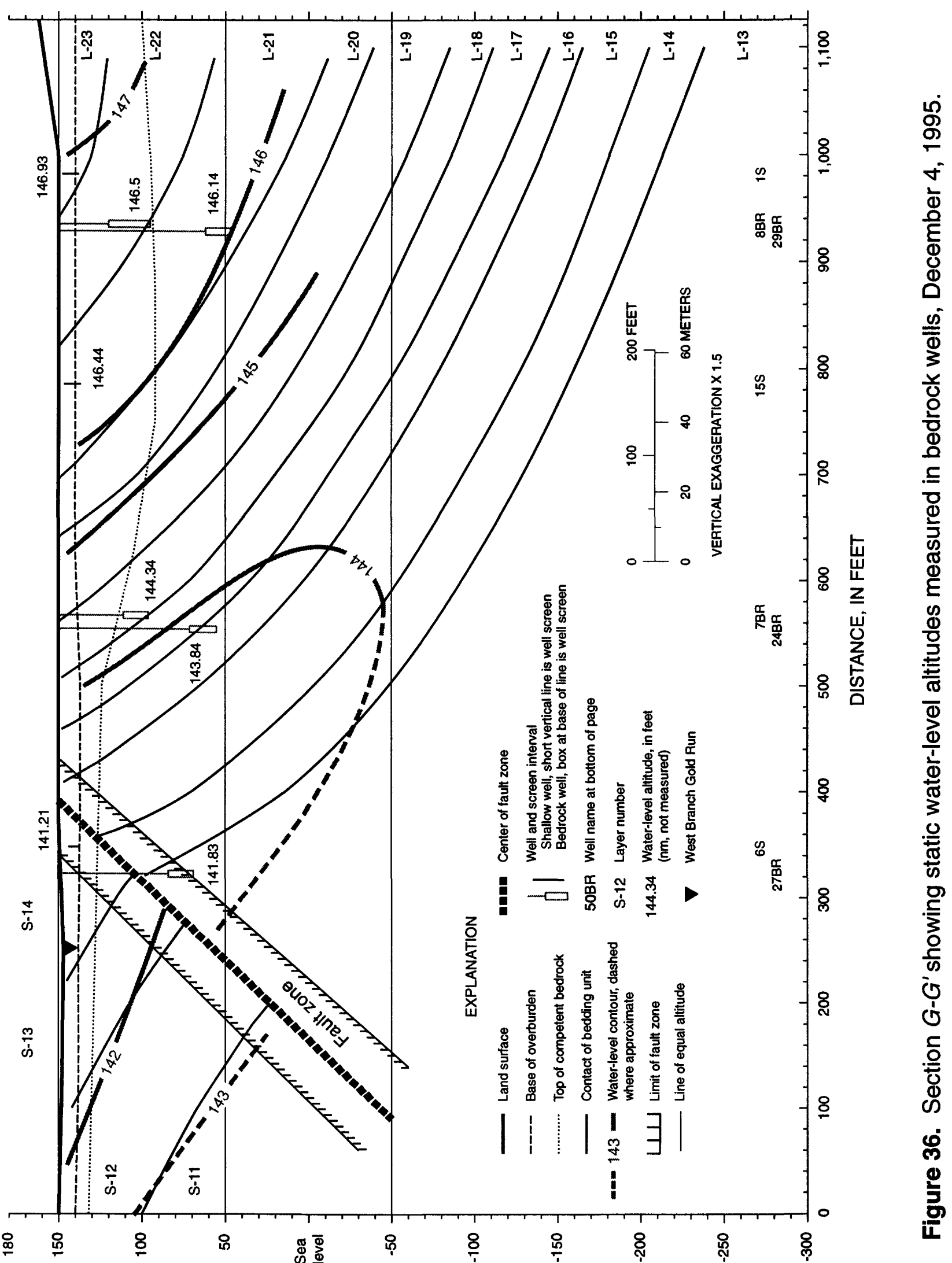




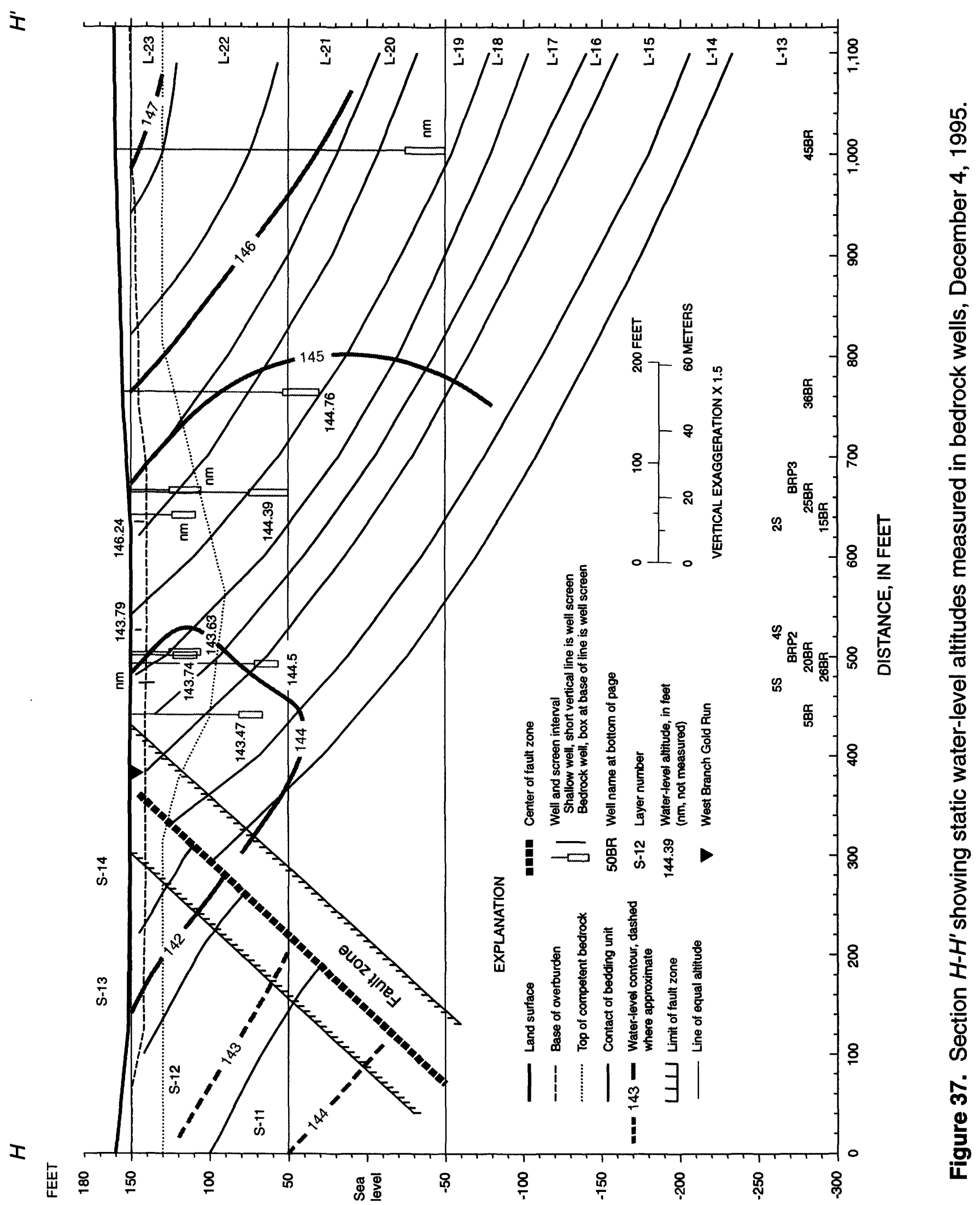




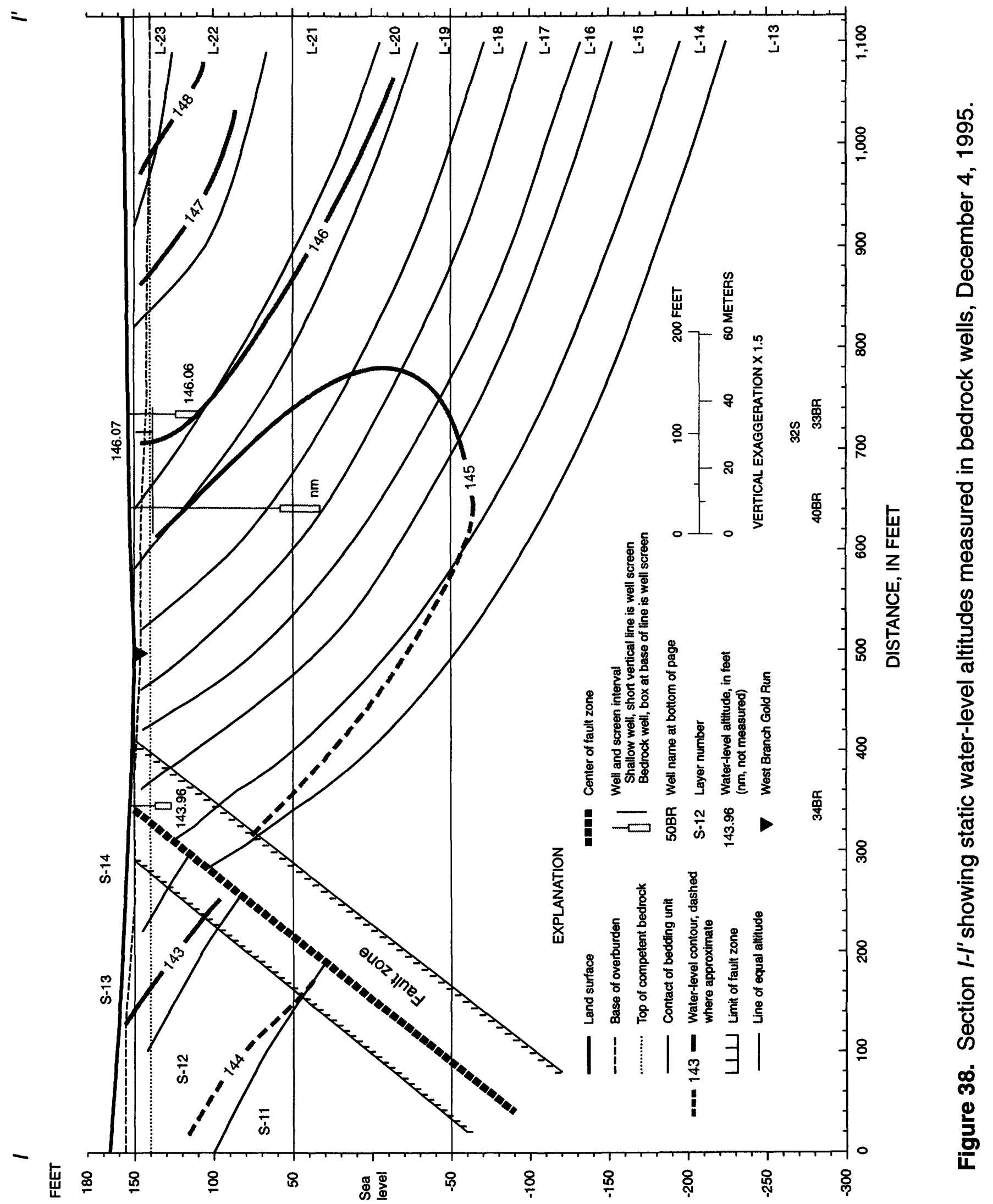


or westward in each section. Well nests that show a downward hydraulic gradient include wells 7BR and 24BR (line G-G') (fig. 36), wells 8BR and 29BR (line G-G') (fig. 36), and wells 23BR and 4BR (line F-F') (fig. 35). A well nest that shows a subtle upward hydraulic gradient is wells 26BR and 5BR (line $\mathrm{H}-\mathrm{H}^{\prime}$ ) (fig. 37).

Wells in a bedding unit or in a pair of bedding units that show a westward flowpath include wells 14BR and 8BR in bedding unit L-22, wells 29BR and 33BR in bedding unit L-21, wells $2 B R$ and 16BR in bedding units L-19 and L-20, wells 16BR and 36BR in bedding unit $\mathrm{L}-19$, wells $30 \mathrm{BR}$ and $20 \mathrm{BR}$ in bedding unit L-17, and wells 23BR and 5BR in bedding units L-15 and L-16 (figs. 28 to 38 ).

The water-level contours at an altitude of $+50 \mathrm{ft}$ show an elongate potentiometric surface low on the north side of the fault that is centered on bedding units L-15 and L-16 under building 40 (fig. 29). The lowest water levels at this altitude of $+50 \mathrm{ft}$ and north of the fault are delineated by the 144-ft contour line. Inside the 144-ft contour line the lowest water level is below the West Branch of Gold Run. The hydraulic gradient beneath Gold Run is upward. Ground-water flowpaths in part are upward in this region with ground-water discharging to the West Branch of Gold Run. The result of this upward flow is increased discharge at Spring 1 and increased flow in the upper reaches of the West Branch of Gold Run.

The water-level contours on the south side of the fault are interpreted to show that the hydraulic gradient is upward and/or toward the West Branch of Gold Run (figs. 28-38). Well set 28BR and 22BR (line F-F') (fig. 35) shows an upward hydraulic gradient. Water levels in well 6BR (line E-E') (fig. 34) were measured more than 10 times during 1996-97. The water level was above land surface each time. Therefore, there is an upward hydraulic gradient in this area. The high water levels in well 6BR were previously attributed to a rupture in a public-supply water main near the well; however, the author interprets that the high water levels in well 6BR are a result of the elevated recharge area of bedding unit $\mathrm{S}-11$. The outcrop for bedding unit $\mathrm{S}-11$ is located south of the well on the hill own od by the Benevolent and Protective Order of the Elks (Elks Club). The hydraulic head created by the elevated land is causing elevated water levels in well 6BR. This feature is described in the methods section (figs. 3 and 5).

The hydraulic gradient near wells $32 \mathrm{BR}$ and 37BR is very steep (figs. 2, 28, and 29), and it is possible that there is a confining unit in this area. As discussed in the hydroge logic framework, it is possible that the fault dces not bend northward at well 31BR but rather it is traced to the east to a short distance south of well 50BR. The mapped location of the fault is based on evidence found in rock core from well 51BR. Further hydrogeologic investigations may be needed refine the location of the fault in the area between wells 32BR and 51BR.

\section{Drawdown Water Levels During Aquifer Tests}

Water-level data from three aquifer tests show water-level drawdowns in the purned well and in selected wells surrounding the pumped well. Interpretation of the data show (1) that the ground-water flow under pumping conditions is predominantly within the bedding units and (2) that shallow parts of the bedding units are typically less permeable and/ or contain more water in storage than the deep parts of the bedding units.

\section{Aquifer test on Well 15BR}

The first aquifer test was conducted on April 8-12, 1993. Well 15BR (line H-H') (fig. 45 ), which is screened in bedding unit L-19, was pumped at a rate of $25 \mathrm{gal} / \mathrm{min}$ for 72 hours. The 23 wells surrounding the purnped well were monitored for water-level draw- 
downs. Maps and sections show the waterlevel drawdown in the 24 wells monitored during the aquifer test (figs. 39 to 46 ).

The results of pumping revealed two hydraulic characteristics of the bedrock aquifer. The first characteristic is that drawdown, and therefore flow, is predominantly within bedding unit L-19 while under pumping conditions. Water levels declined 2.95 and $3.87 \mathrm{ft}$ in wells $36 \mathrm{BR}$ and $38 \mathrm{BR}$ respectively. It is interpreted that there is a very good connection between wells $15 \mathrm{BR}$, $36 \mathrm{BR}$, and $38 \mathrm{BR}$ via bedding partings of bedding unit L-19. Water levels declined about 1.0 to $2.31 \mathrm{ft}$ in wells screened in bedding units L-18 through L-21, and water levels in wells in bedding units L-15, L-16, L-17, and L-22 declined 0.45 to $0.97 \mathrm{ft}$. Water levels in bedding units on the south side of the fault showed no water-level drawdown.

The second hydraulic characteristic of the bedrock aquifer is that the shallow part of most bedding units is less permeable and/or contains more water in storage than the deep part of the same bedding unit. The drawdown in the shallow wells is less than drawdown in wells that are in the deeper part of the same bedding unit. For example, drawdown in deep bedrock wells $36 \mathrm{BR}$ and $38 \mathrm{BR}$ is 2.95 and $3.57 \mathrm{ft}$, respectively, whereas drawdown in shallow bedrock wells $16 \mathrm{BR}$ and $17 \mathrm{BR}$ is 1.52 and $1.12 \mathrm{ft}$, respectively. All four wells are screened in bedding unit L-19.

Two maps show drawdown for the Lockatong aquifer and one map shows drawdown for bedding unit L-19. The first map shows drawdown at an altitude of +150 $\mathrm{ft}$, which is about land surface (fig. 39), and the second map shows drawdown at an altitude of $+50 \mathrm{ft}$, which is about $100 \mathrm{ft}$ below land surface (fig. 40). Both maps show that the center of the elongate cone of depression stayed within bedding unit L-19. The drawdown maps show that drawdown along the strike of the bedding is about four times greater than the drawdown perpendicular to the bedding plane. The hydraulic gradient is about four times greater along strike than it is perpendicular to the strike direction or a ratio of 4:1, thus the Lockatong aquifer in this region is quite anisotropic.

The third map shows drawdown in the plane of bedding unit L-19 based on waterlevel drawdown values from 7 wells (fig. 41). The map shows that drawdown in the down dip direction is about half of drawdown along the strike direction. Therefore, individual bedding units are more isotropic with a ratio of about 2:1 than the Lockatong aquifer when taken as a whole with a ratio of $4: 1$.

In summary, the Lockatong aquifer is interpreted to have an anisotropic hydraulic conductivity based on the shape of the contours in drawdown maps. However, individual bedding unit $\mathrm{L}-19$ or water-bearing zones in the bedding units have a nearly isotropic hydraulic conductivity. In addition, based on water level drawdown data, more water is available in storage in the shallow part than in the deep part of each bedding unit. The high fracture density in the shallow part of the bedding units accounts for the higher storage capacity. The shallow part of each bedding unit is less permeable than the deep part of the same bedding unit because more of the rock has weathered to a clay in the shallow part than in the deep part of the same aquifer. As a result of the higher storage and less permeability in the shallow pats of the bedding unit, the areal extent of the cone of depression is less in the shallow part of the bedding units than in the deep part of the same bedding unit.

\section{Aquifer test on Well BRP1}

A second aquifer test was conducted on August 9-12, 1995. Well BRP1, screened in bedding units L-19 and L-20, was pumped at a rate of $25 \mathrm{gal} / \mathrm{min}$ for 48 hours while eight wells surrounding the pumped well were monitored for water-level drawdown. 


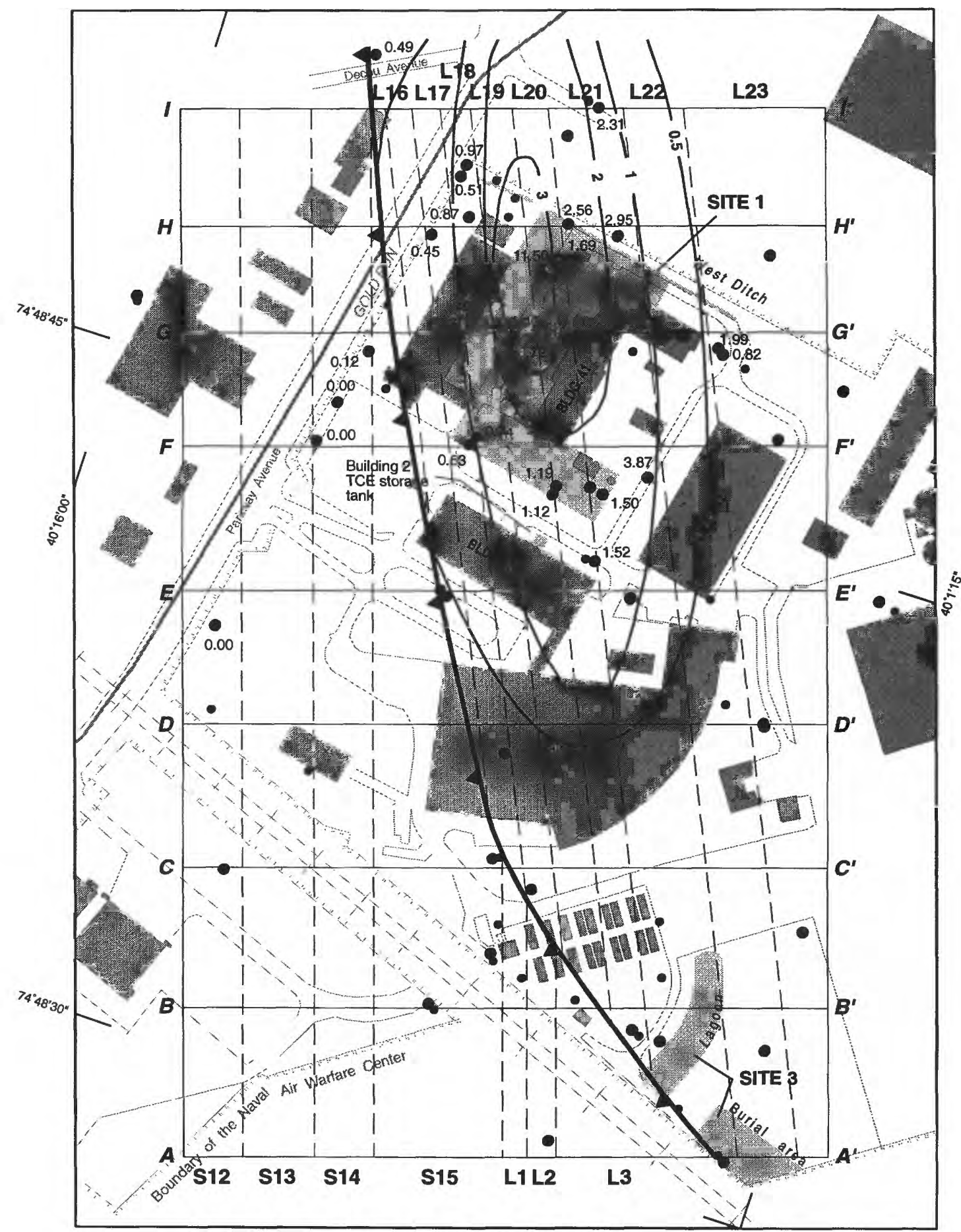

EXPLANATION

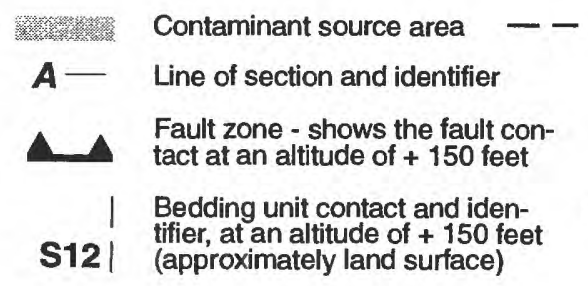

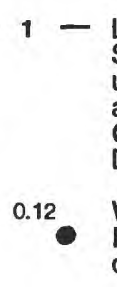

LINE OF EQUAL DRAWDOWN-Shows drawdown relative to the unstressed potentiometric surface at and altitude of +150 feet. Contour interval (in feet) is variable. Dashed where approximate

Well open to bedrock. Number is water leve drawdown, in feet

\section{- Well in unconsolidated material \\ 11.50 Well 15BR, pumped during aquifer test. Number is water level drawdown, in feet}

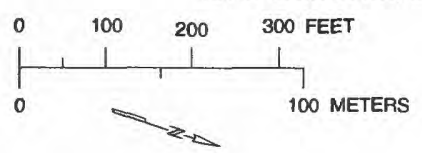

Figure 39. Drawdown during the aquifer test with well 15BR pumping, shown at an altitude of +150 feet (approximately land surface), Naval Air Warfare Center, West Trenton, N.J. 


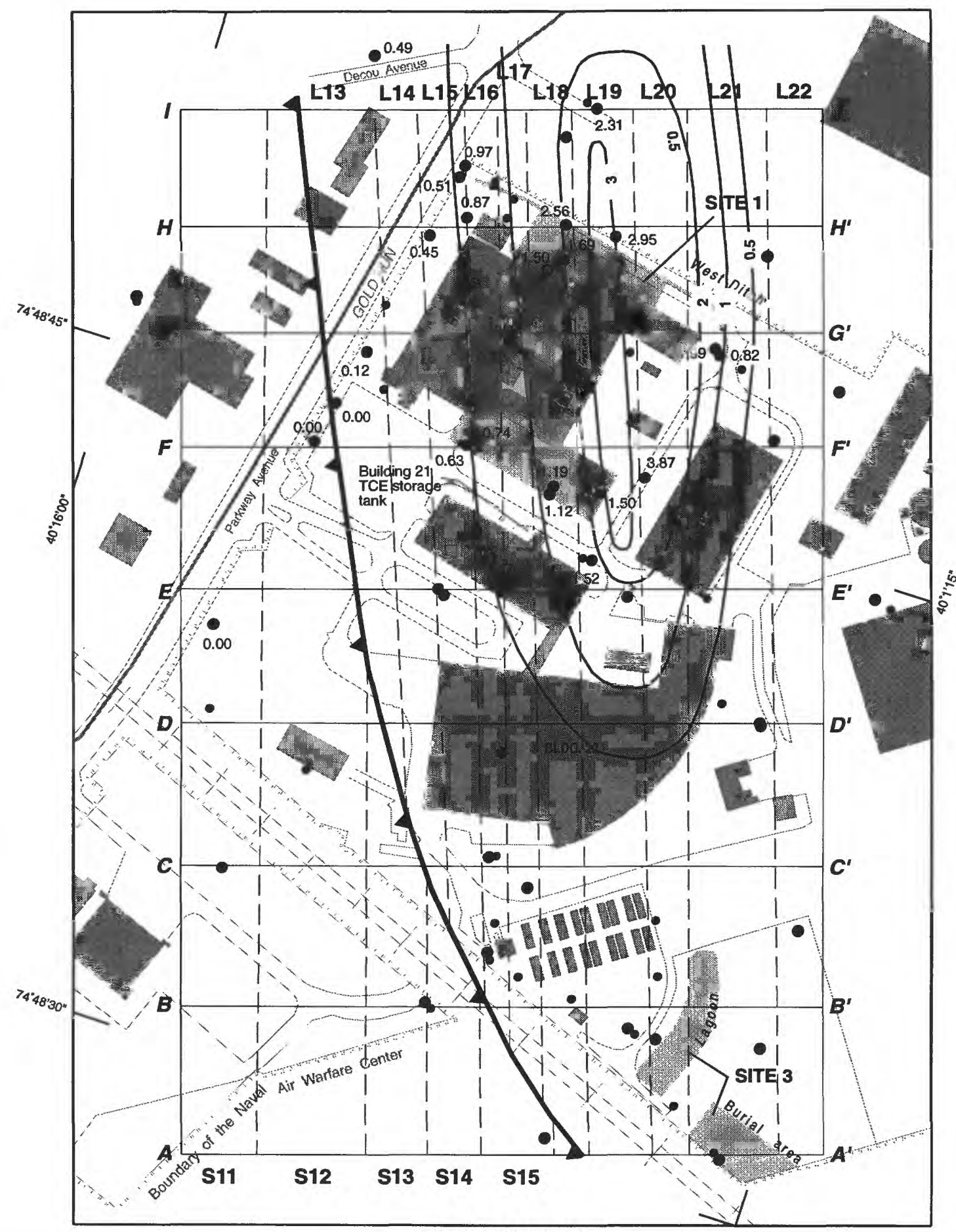

EXPLANATION

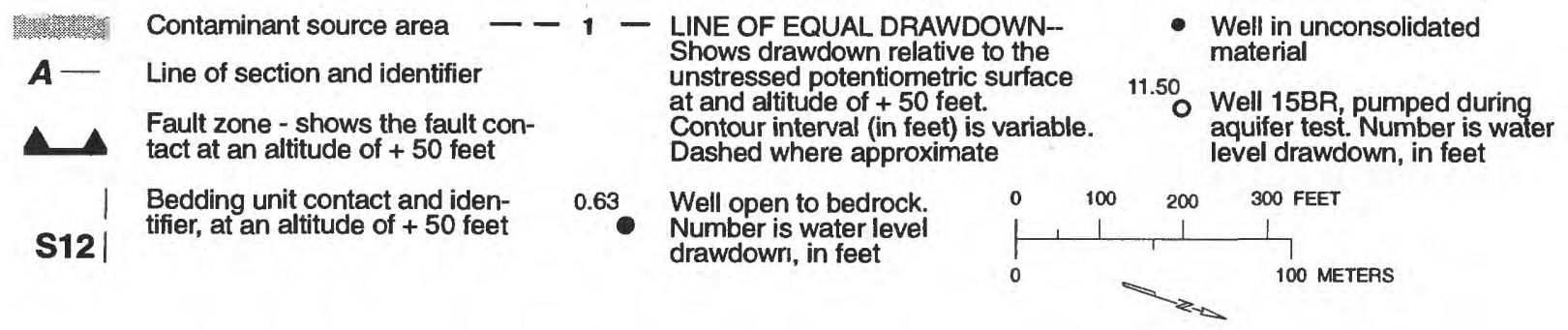

Figure 40. Drawdown during the aquifer test with well 15BR pumping, shown at an altitude of +50 feet (approximately 100 feet below land surface), Naval Air Warfare Center, West Trenton, N.J. 


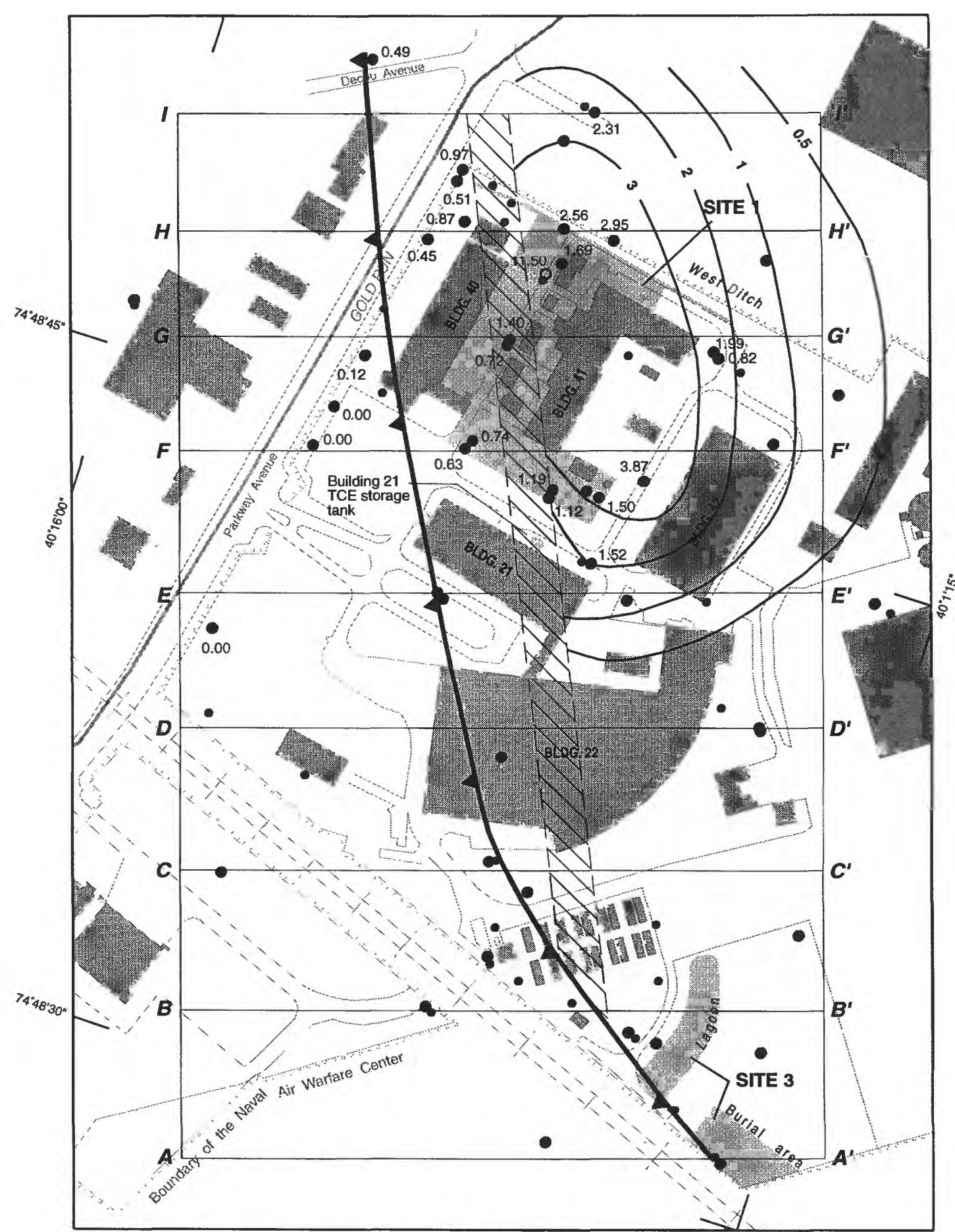

EXPLANATION

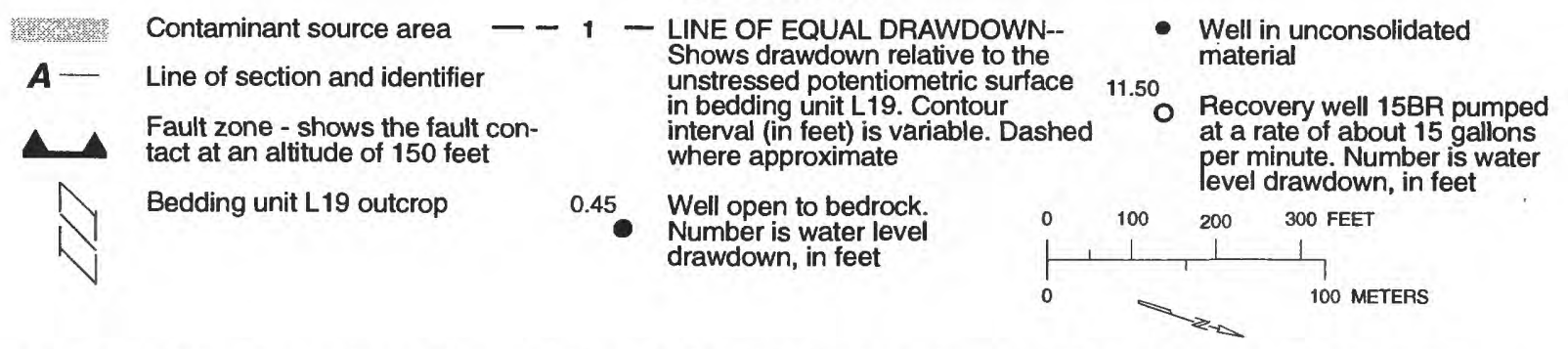

Figure 41. Drawdown in bedding unit L19 during the aquifer test with well 15BR pumping, Naval Air Warfare Center, West Trenton, N.J. 


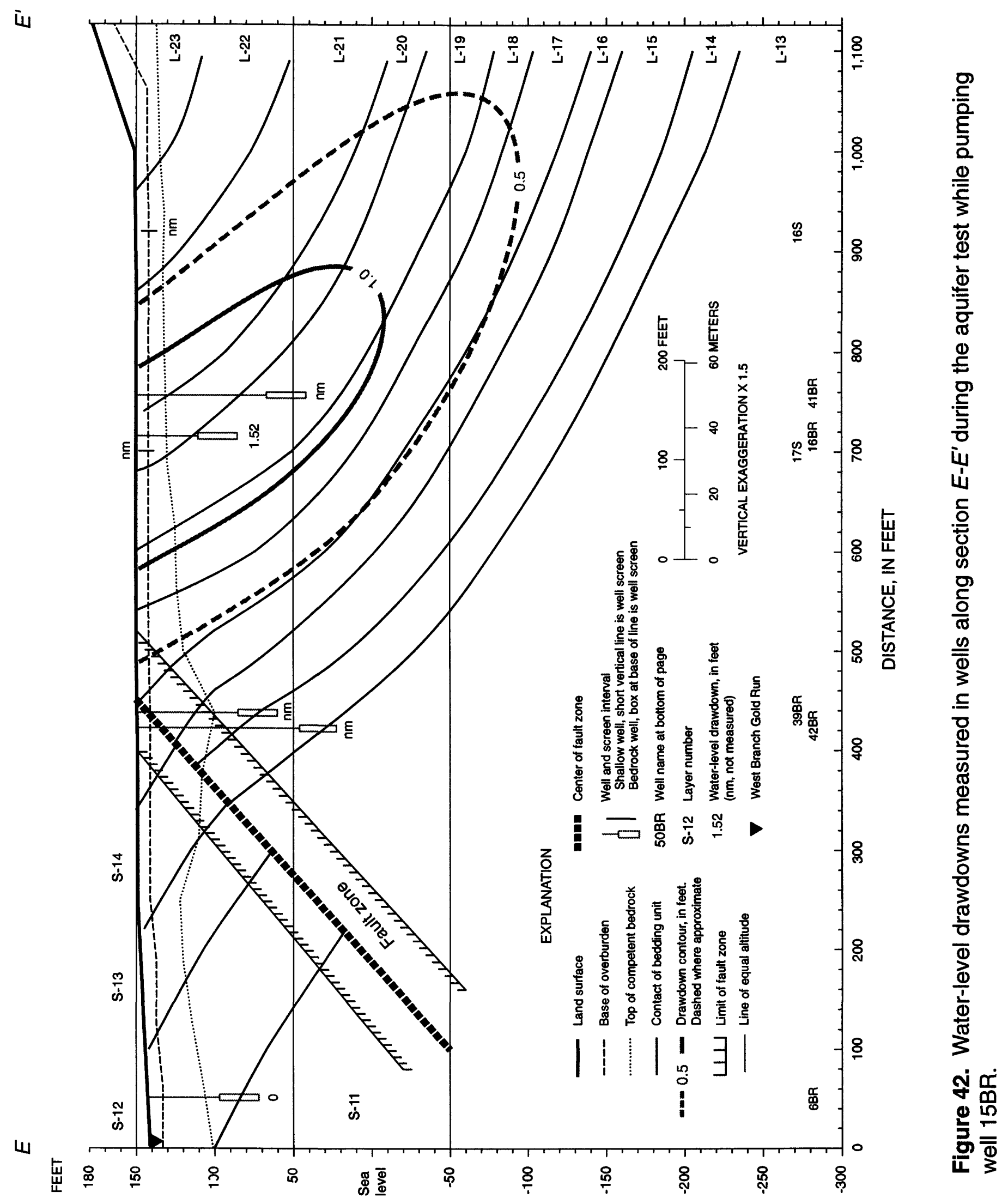




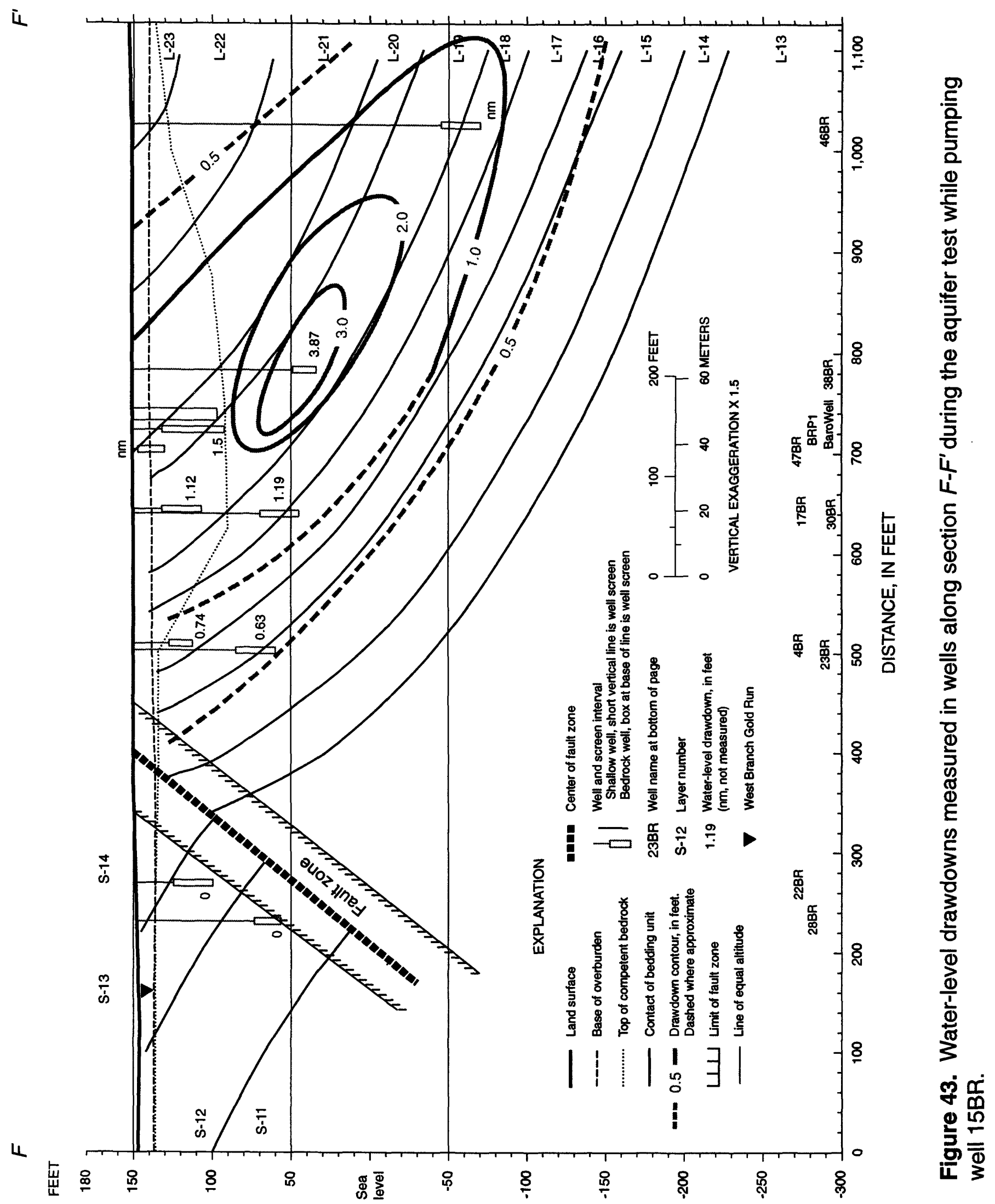


i

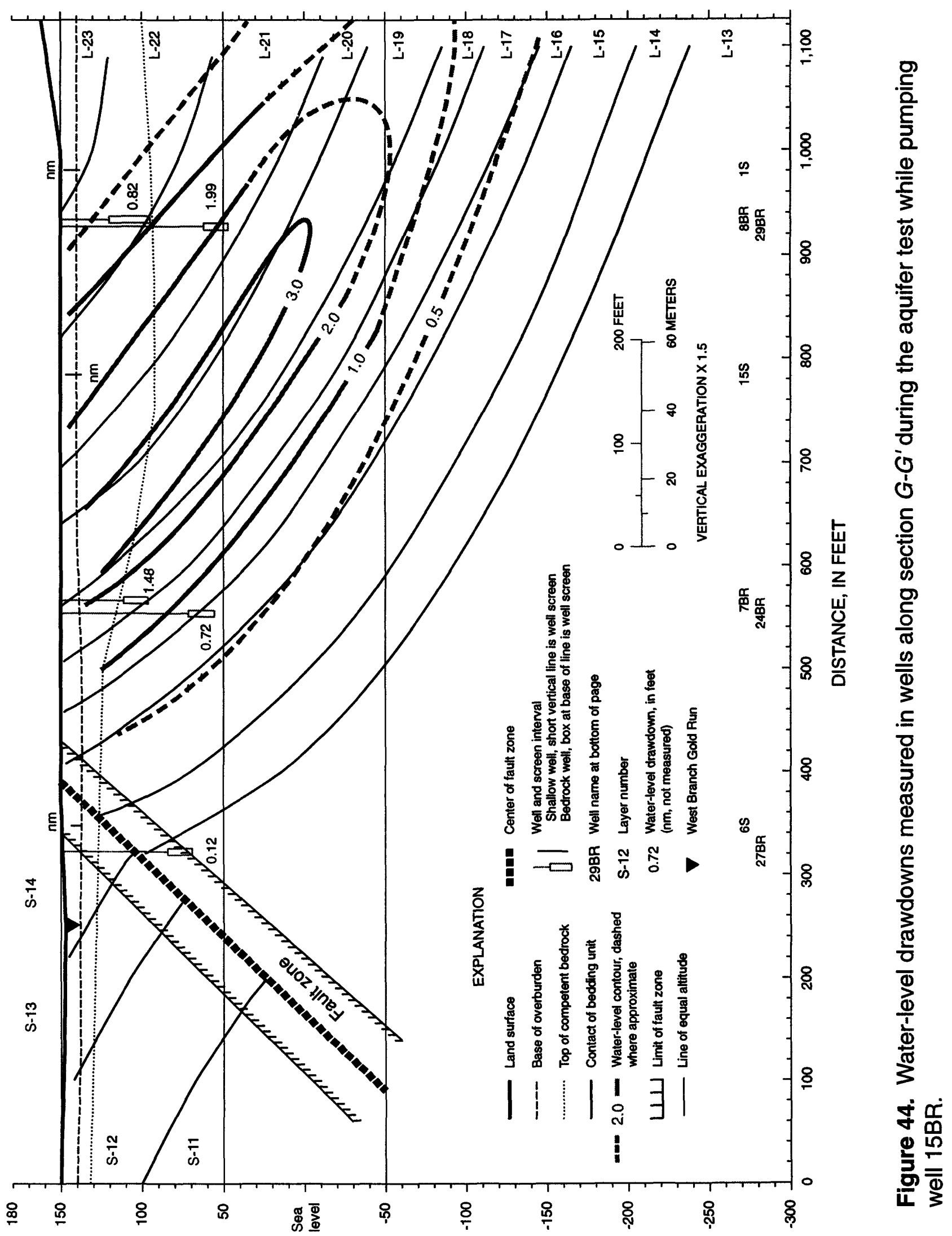




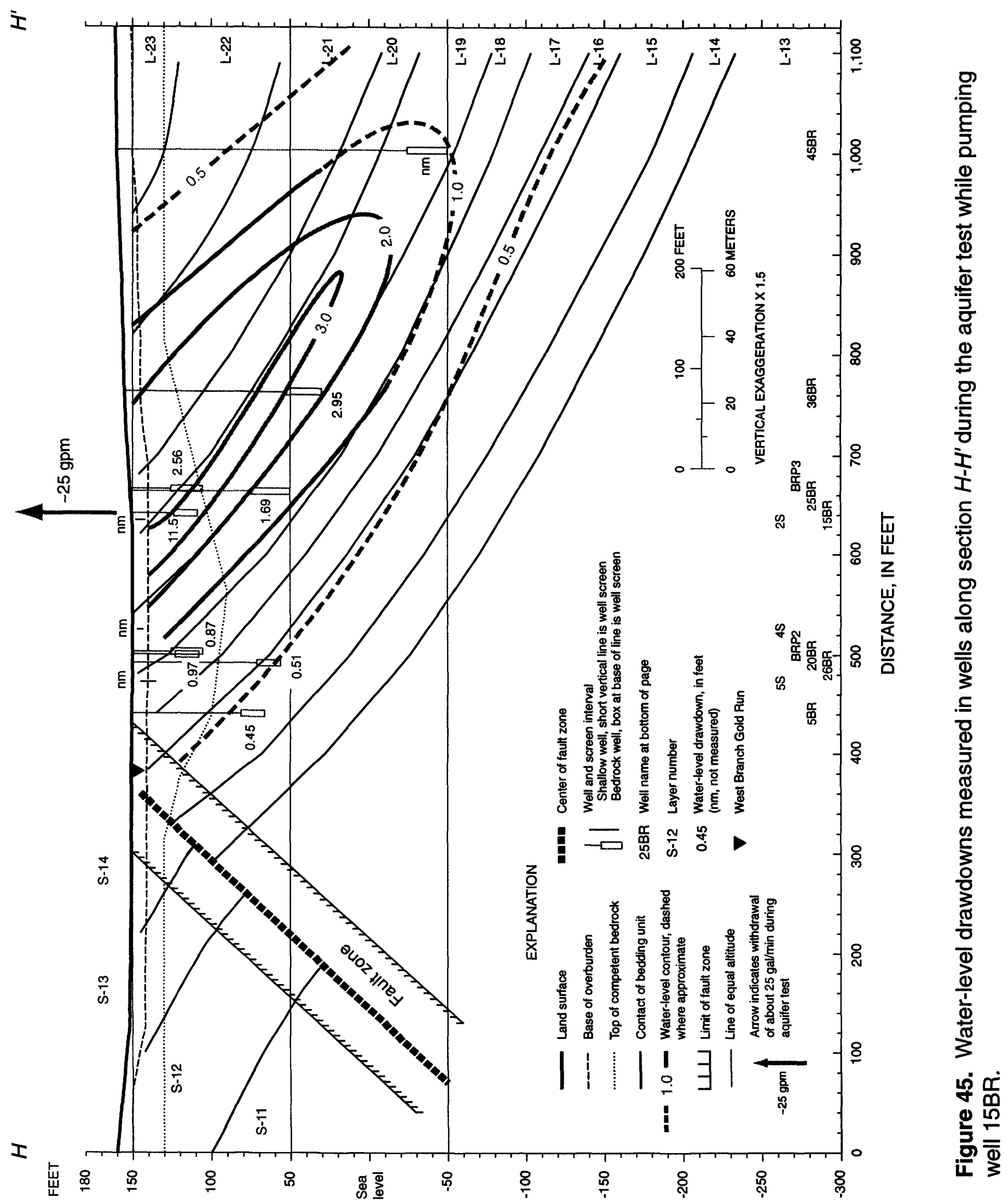




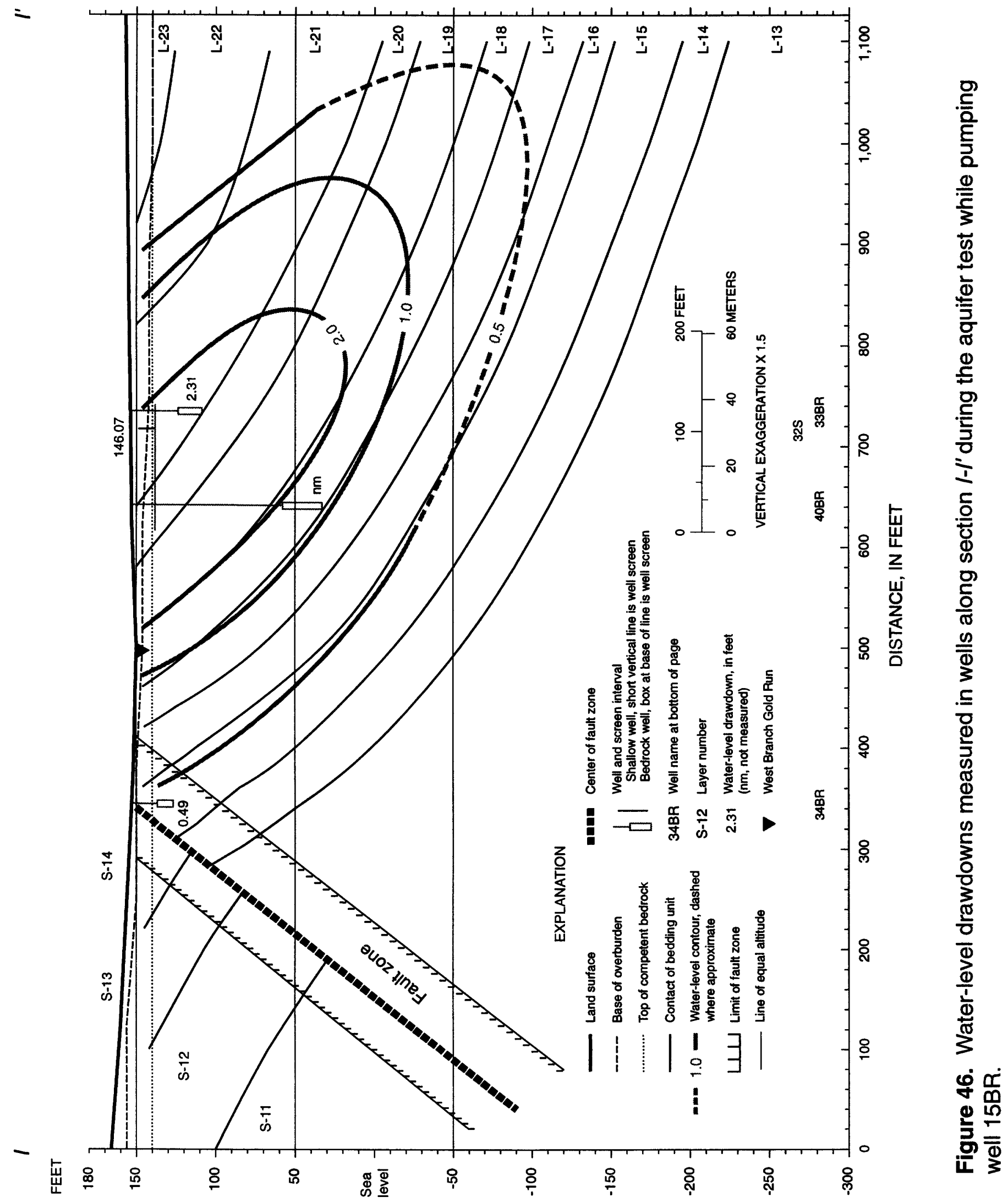


Drawdown sections and maps (figs. 47 to 51) show the drawdown in the nine wells that were monitored during the aquifer test.

Well BRP1, the pumped well, is located about $40 \mathrm{ft}$ east of the "Barometric well" (line F-F') (fig. 50). The Barometric well is not actually a well but rather an underground tank that is $12 \mathrm{ft}$ in diameter and about $50 \mathrm{ft}$ deep. The Barometric well was used as part of the work effort at the NAWC. It was installed in 1958 by drilling and blasting a hole in the bedrock that was 25 to $30 \mathrm{ft}$ in diameter and about $60 \mathrm{ft}$ deep. During the installation of well 38BR, the driller and site geologist noted air being released from the ground surrounding the Barometric well. The method of installation of the Barometric well and the subsequent release of air during drilling of well 38BR indicate that the bedrock near the Barometric well is highly fractured due to the blasting. In addition, it is likely that blasting fractured the rock where well BRP1 is located.

The results of the aquifer test show that well 16BR screened in bedding unit L-19 and well 29BR screened in bedding unit L-21 have drawdowns of 1.83 and $1.82 \mathrm{ft}$ respectively. These drawdowns are the largest of the nine wells that were measured. Well 16BR is about $130 \mathrm{ft}$ and well 29BR is about $340 \mathrm{ft}$ from the pumped well; however, well 16BR is screened about $50 \mathrm{ft}$ below land surface, and well 29BR is screened about $90 \mathrm{ft}$ below land surface. Although the drawdowns are nearly equal in the two wells, there is less relative drawdown in well 16BR than in well 29BR because it is shallower, in spite of it being closer to and in the same bedding unit as well BRP1. As a result, (a) more water is stored in the shallow part of the aquifer, (b) the shallow part of the aquifer is less permeable, and/or (c) a confining unit is present between the waterbearing zone of the pumped well and well 16BR.

Wells screened in bedding units below L-19 had drawdowns of 0.15 to $0.4 \mathrm{ft}$, and the well in bedding units above L-22 had a drawdown of $0.91 \mathrm{ft}$. Water levels were not measured south of the fault, so the effec ${ }^{+}$of drawdown in that area is not known.

The drawdown map at an altitude of $+150 \mathrm{ft}$ (about land surface) (fig. 47) ant at an altitude of $+50 \mathrm{ft}$ (about $100 \mathrm{ft}$ below land surface) (fig. 48) shows that drawdown along strike is about four times greater than it is perpendicular to the strike of the beddin?. Therefore, the Lockatong aquifer has an anisotropy ratio of $4: 1$ at land surface art at a depth of $100 \mathrm{ft}$. There are insufficient $d \varepsilon^{+}$a to draw the drawdown within any bedding unit or set of bedding units. Bedding units L-2O and L-21 have an isotropy ratio that is close to $1: 1$ to a depth of at least $200 \mathrm{ft}$ below land surface because there was a $1.82 \mathrm{ft}$ of drawdown in well 29BR, which is screened in the same bedding unit as the pumped well.

\section{Aquifer test on Well 5BR}

A third aquifer test was conducted on August 15-17, 1995. Well 5BR, screened in bedding units L-15 (line H-H') (fig. 56) was pumped at a rate of $25 \mathrm{gal} / \mathrm{min}$ for 42 horrurs. Twelve surrounding wells were monitored for water levels. Drawdown sections and maps show the drawdown in the 13 wells monitored during the aquifer test (figs. 52 to 57).

The results of the aquifer test show that wells 26BR, 24BR, and 23BR, screened in bedding units L-15 and L-16, had the lar?est drawdowns ranging from 7.05 to $2.03 \mathrm{ft}$. Wells 4BR and 20BR, screened in bedding unit L-17, showed water-level declines of 1.09 and 0.91 $\mathrm{ft}$, respectively. Water levels declined $0.73 \mathrm{ft}$ in well 7BR located in the shallow part of bedding unit L-18, and water levels did not respond in well 15BR located in the deeper part of bedding unit L-18. Water levels in the fault zone showed a decline of $0.27 \mathrm{ft}$; however, slug test data for well 27BR ( $\mathrm{n}$ inald Rice, U.S. Geological Survey, written commun., 1997) show that the well has an 


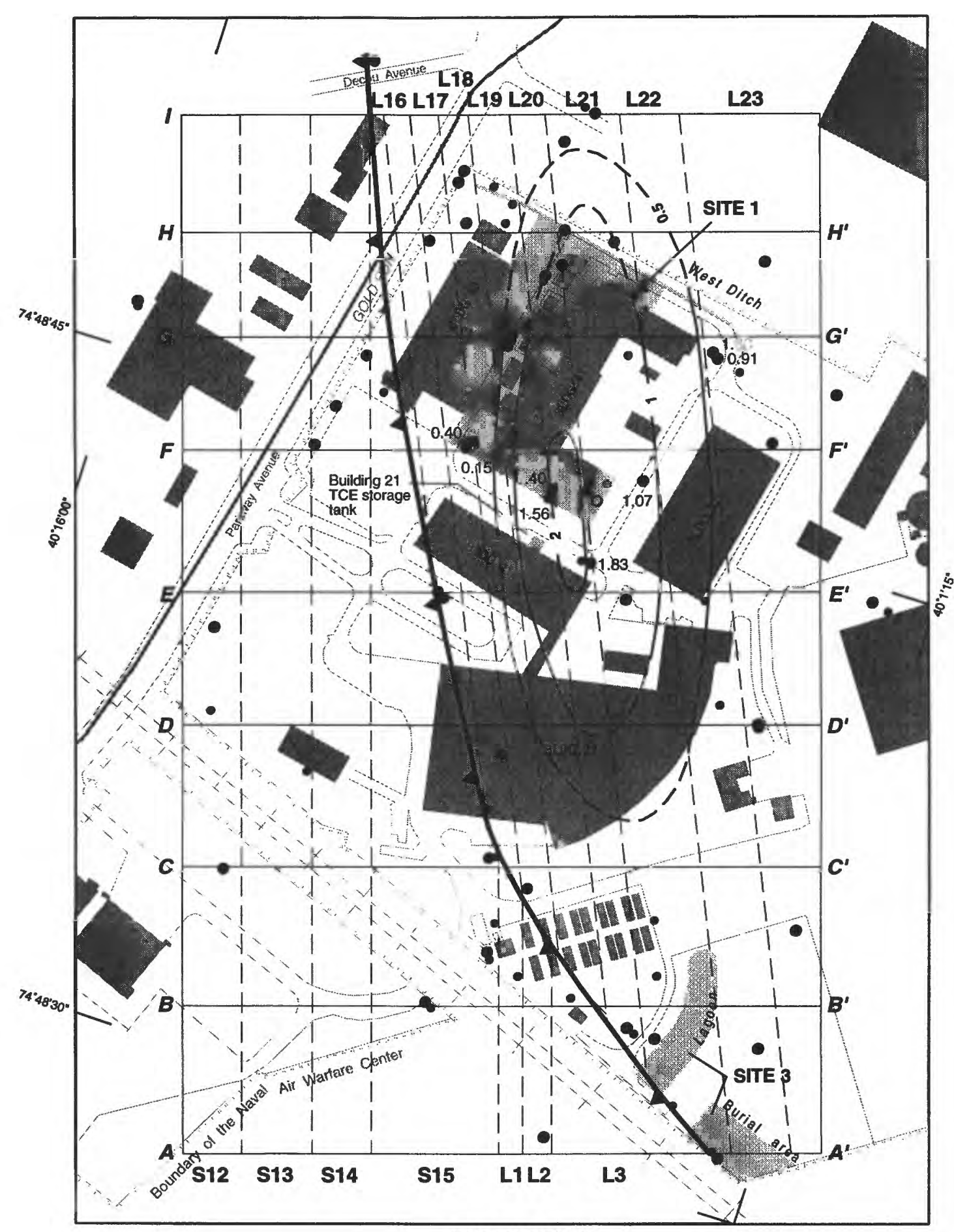

EXPLANATION

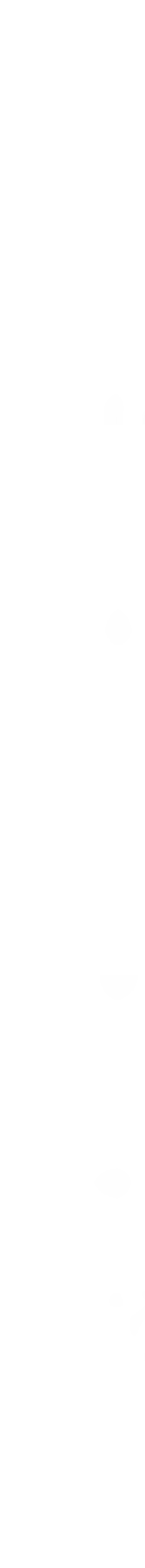

\% Contaminant source area - - 1 - LINE OF EQUAL DRAWDOWN--

\section{A - Line of section and identifier}

Fault zone - shows the fault contact at an altitude of +150 feet

Bedding unit contact and identifier, at an altitude of +150 feet (approxi-

S12 mately land surface)
Shows drawdown relative to the unstressed potentiometric surface at an altitude of +150 feet. Contour interval (in feet) is variable. Dashed where approximate

Well open to bedrock. Number is water level drawdown, in feet
- Well in unconsolidated material

- Well BRP1, pumped during aquifer test

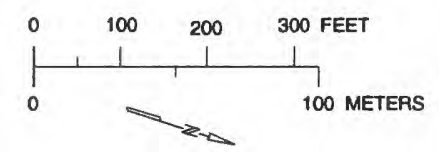

Figure 47. Drawdown during the aquifer test with well BRP1 pumping, shown at an altitude of +150 feet (approximately land surface), Naval Air Warfare Center, West Trenton, N.J. 


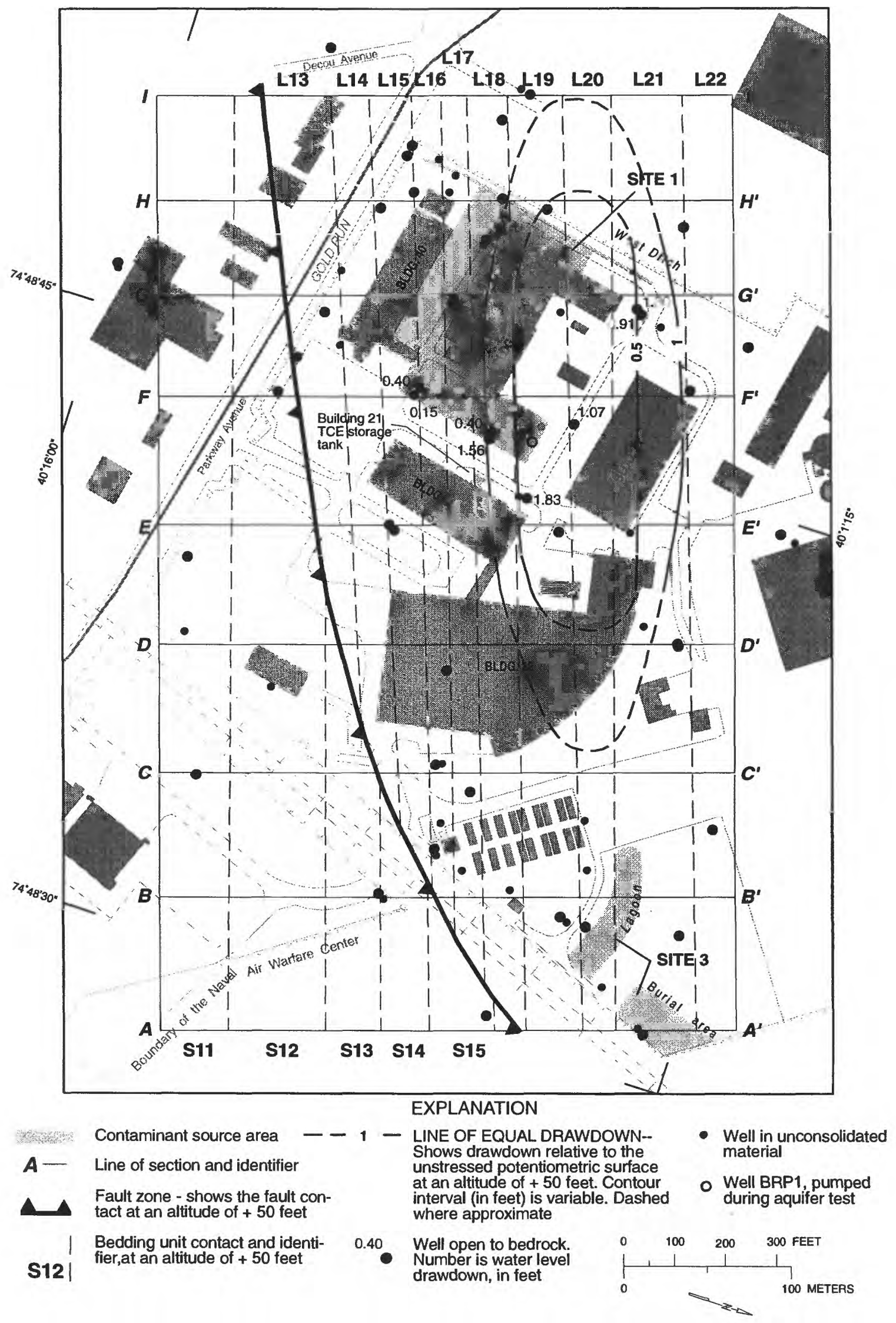

Figure 48. Drawdown during the aquifer test with well BRP1 pumping, shown at an altitude of +50 feet (approximately 100 feet below land surface), Naval Air Warfare Center, West Trenton, N.J. 


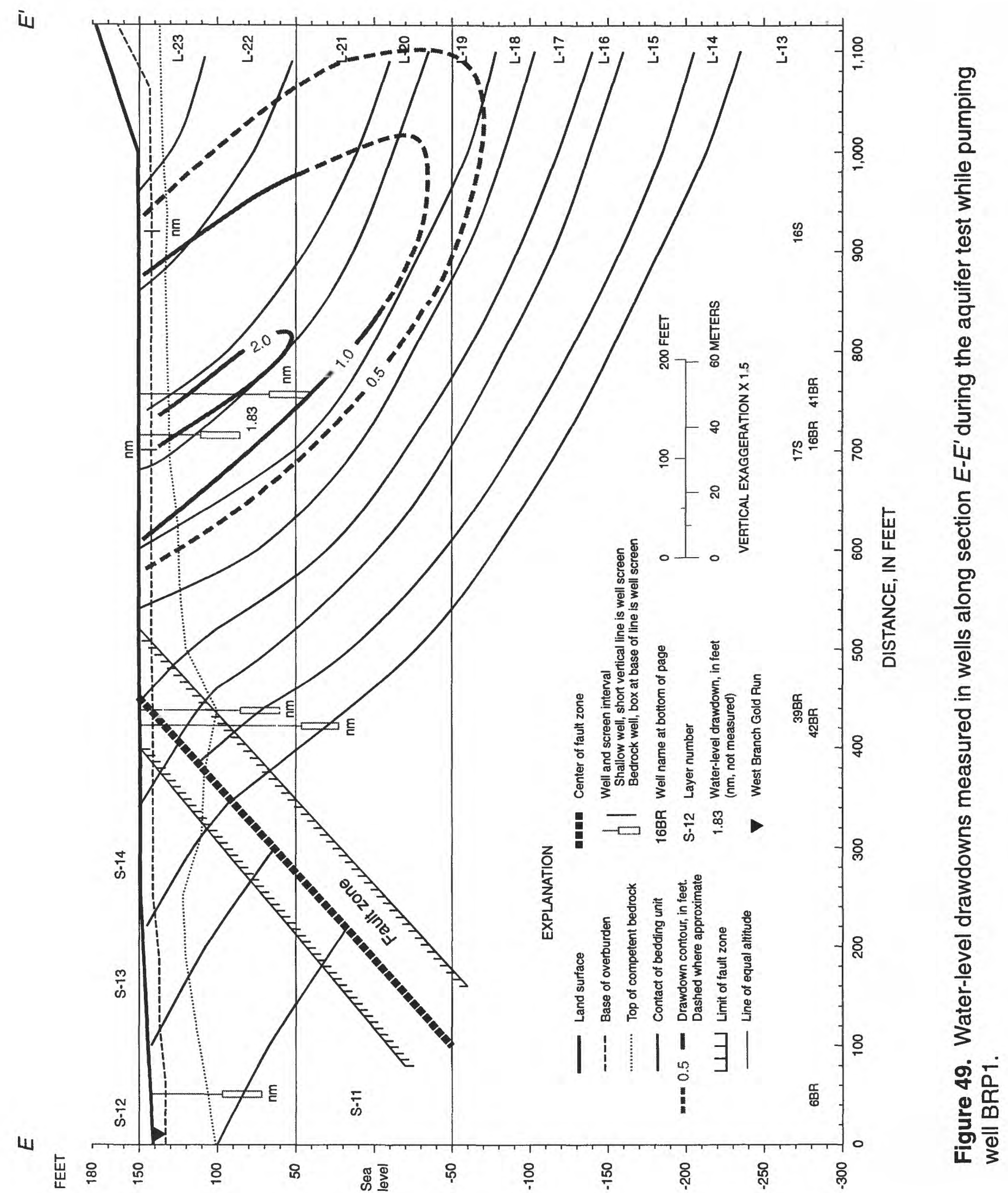




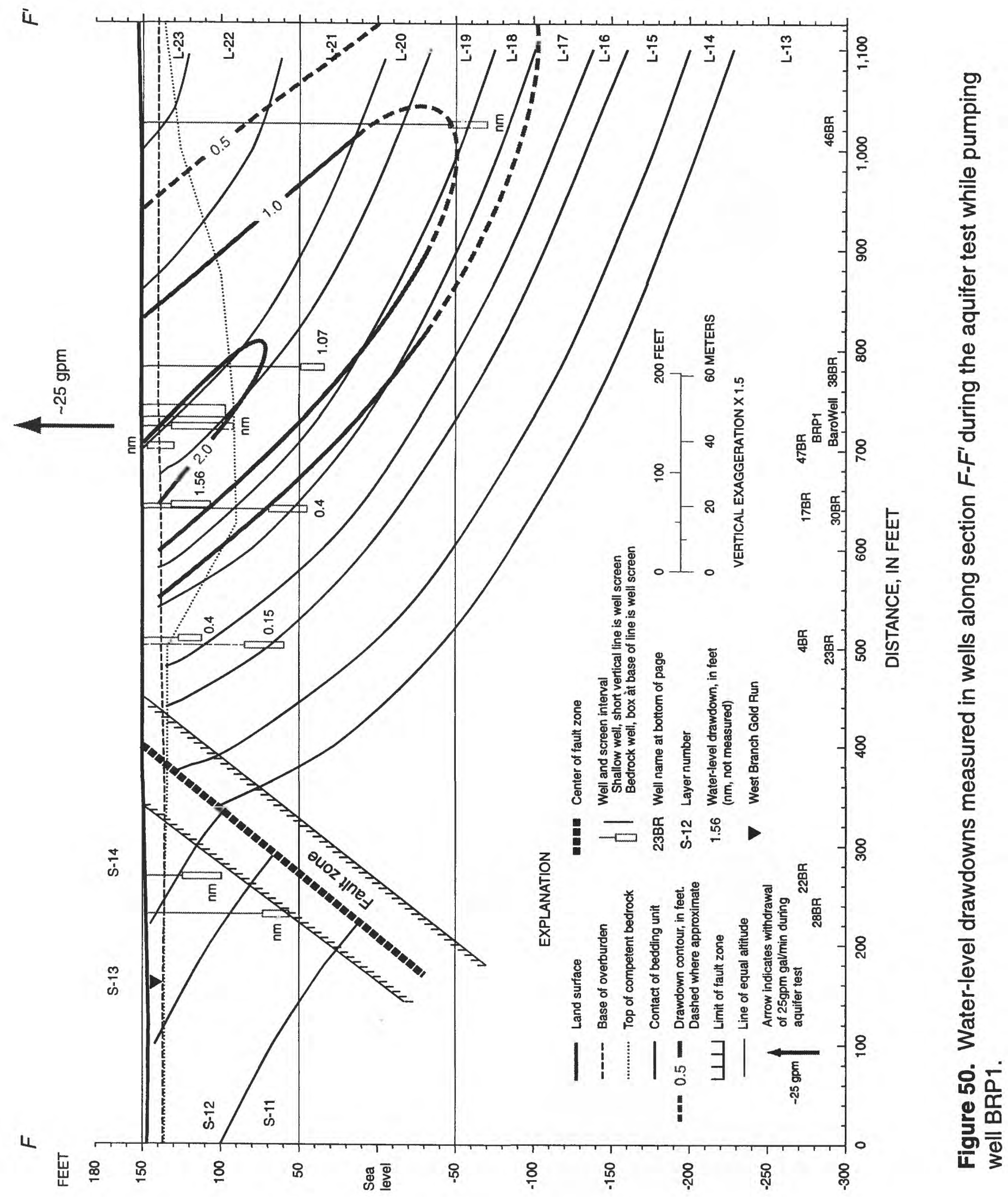


ò

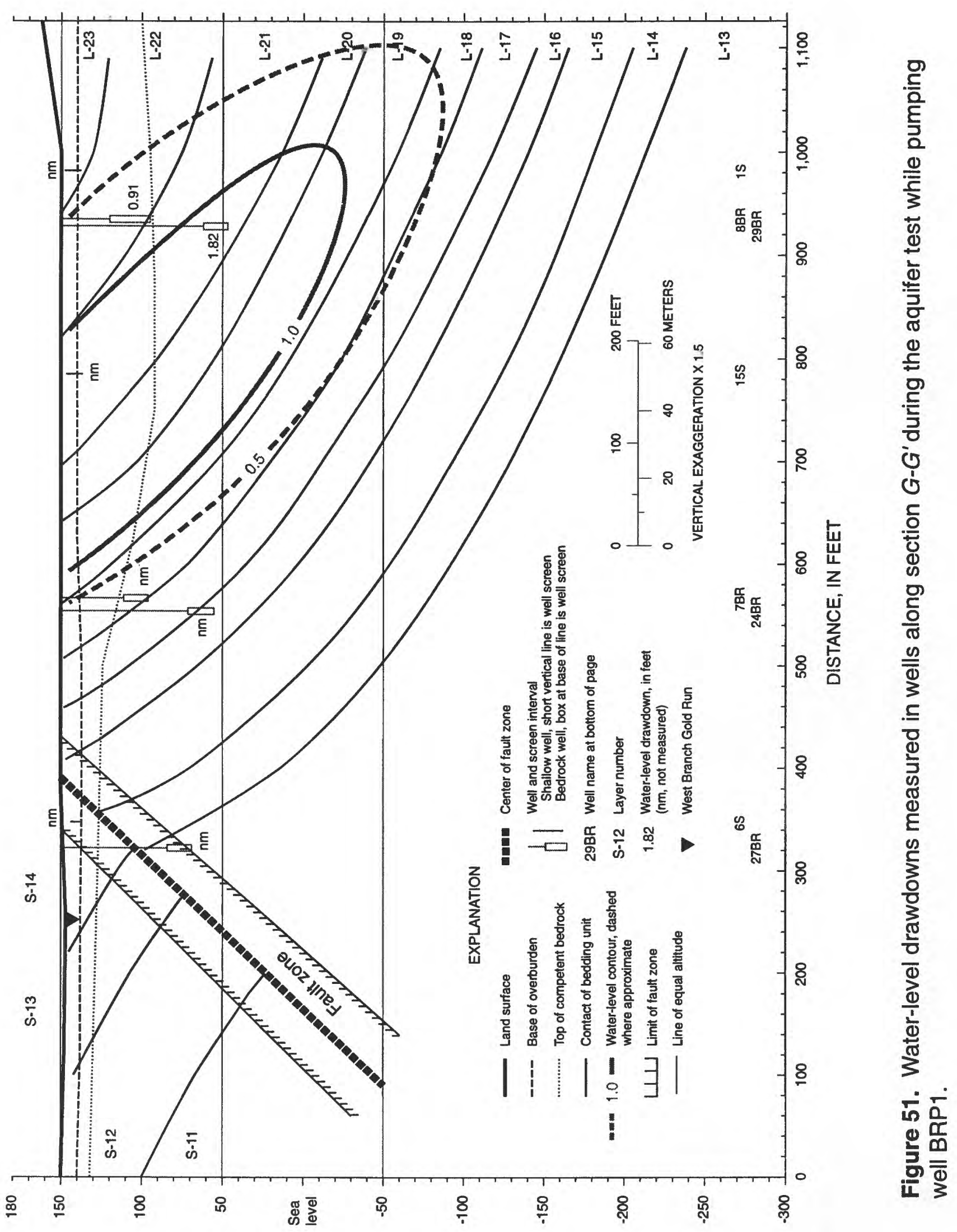




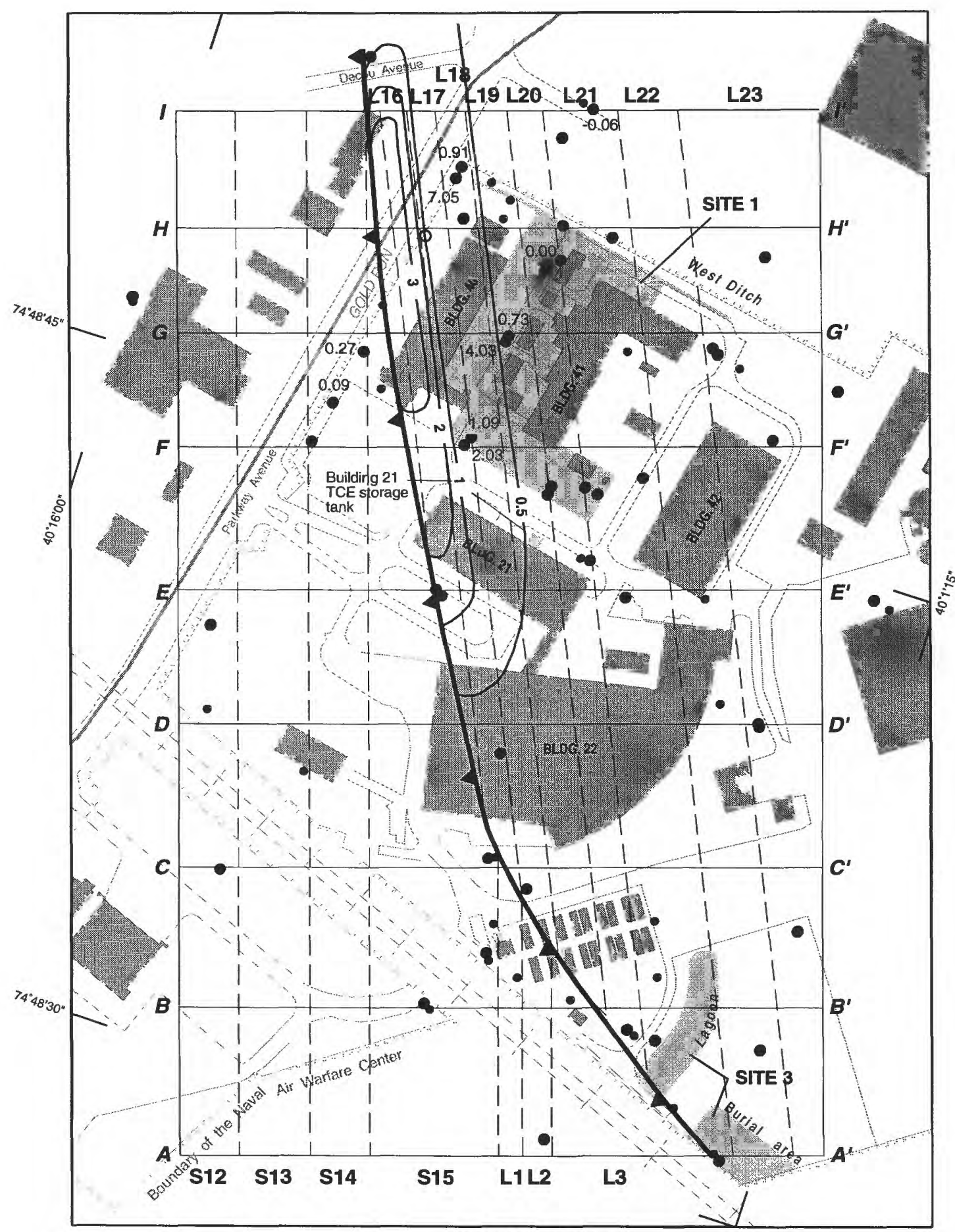

EXPLANATION

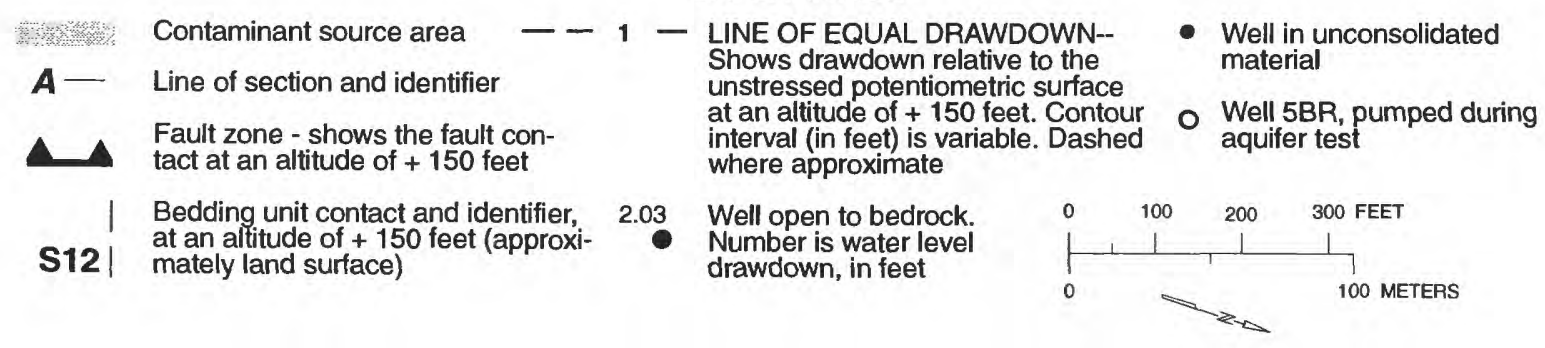

Figure 52. Drawdown during the aquifer test with well 5BR pumping, shown at an altitude of +150 feet (approximately land surface), Naval Air Warfare Center, West Trenton, N.J. 


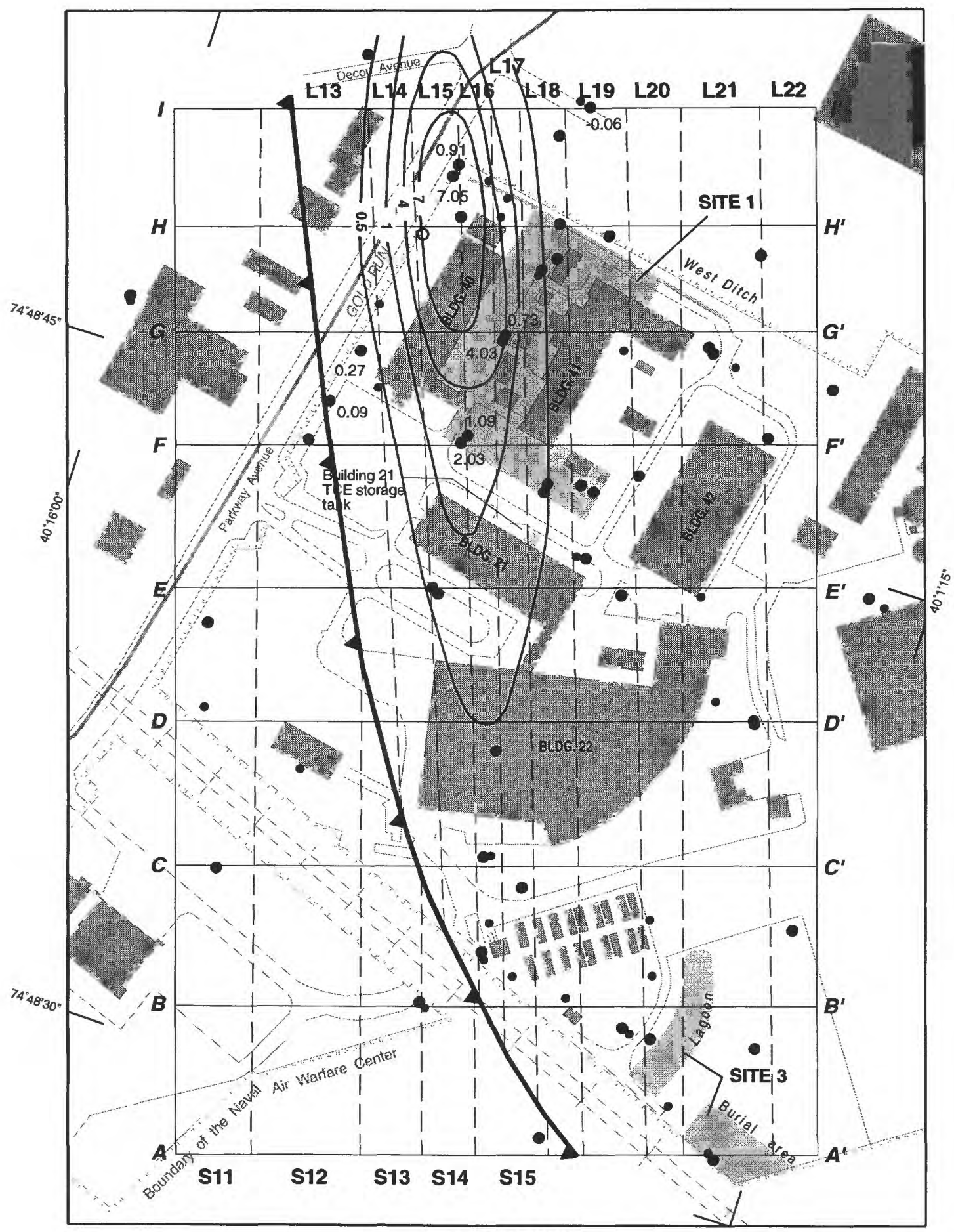

EXPLANATION

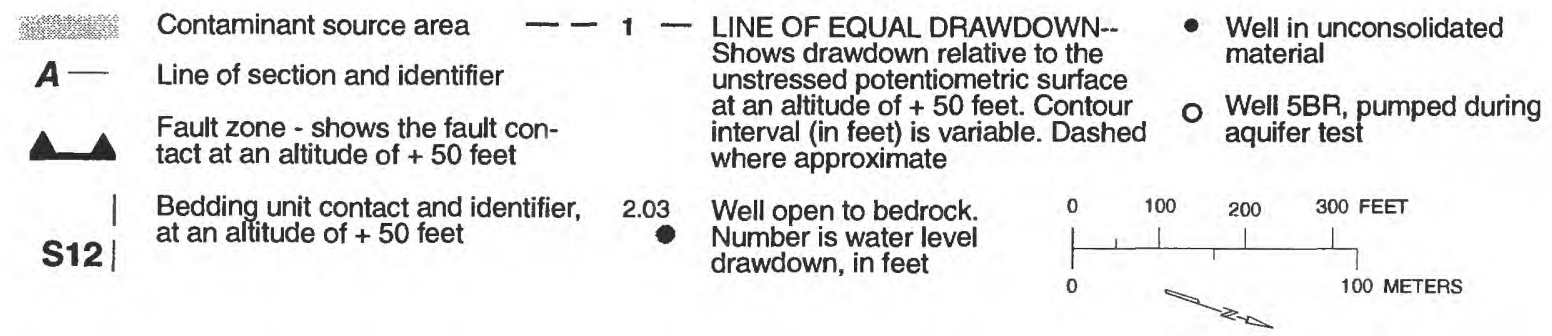

Figure 53. Drawdown during the aquifer test with well 5BR pumping, shown at an altitude of +50 feet (approximately 100 feet below land surface), Naval Air Warfare Center, West Trenton, N.J. 


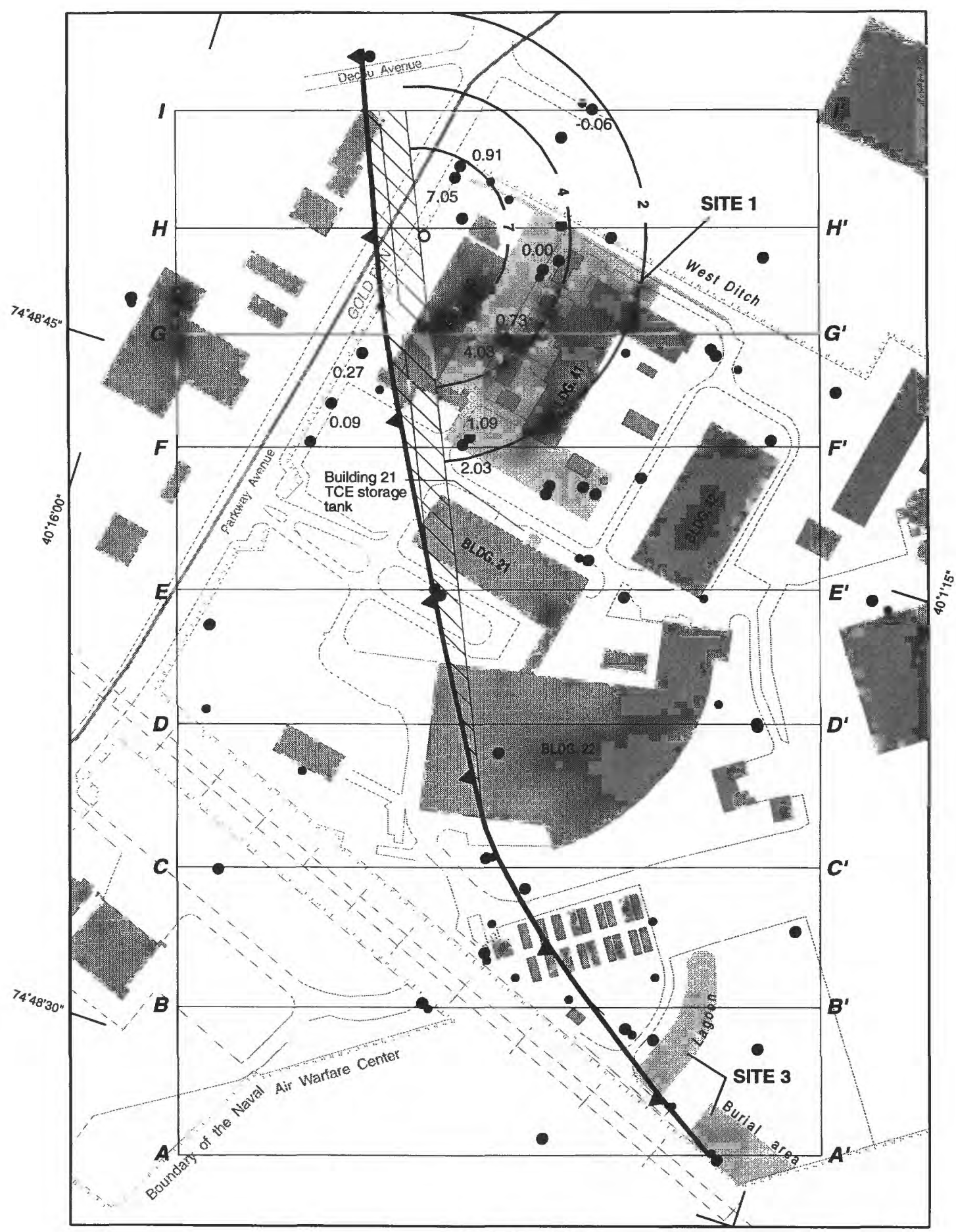

EXPLANATION

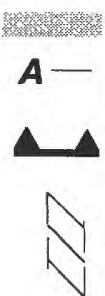

Contaminant source area

Line of section and identifier

Fault zone - shows the fault contact at an altitude of +150 feet

Bedding unit $\mathrm{L}-15$ and $\mathrm{L}-16$

outcrop, at an altitude of +150

feet (approximately land surface)

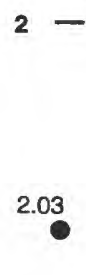

LINE OF EQUAL DRAWDOWNShows drawdown relative to the unstressed potentiometric surface in bedding unit L16. Contour interval (in feet) is variable. Dashed where approximate

.03 Well open to bedrock. Number is water level drawdown, in feet
- Well in unconsolidated material

○ Well 5BR, pumped during aquifer test

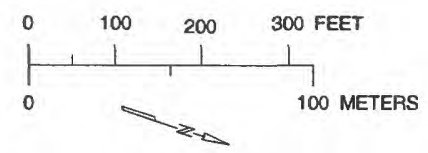

Figure 54. Drawdown in bedding unit $L 15$ and $L 16$ during the aquifer test with well 5BR pumping, Naval Air Warfare Center, West Trenton, N.J. 
is

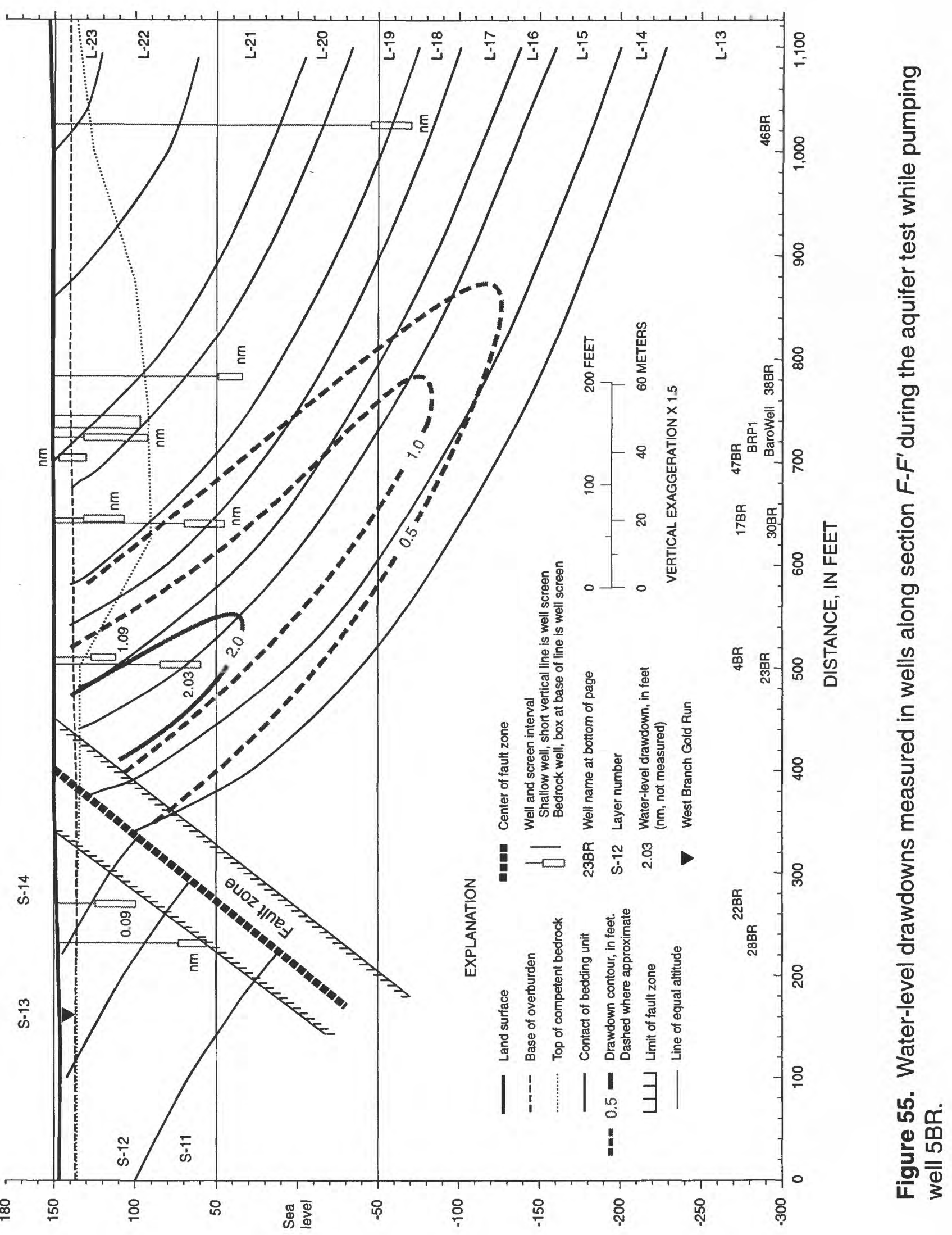


ī

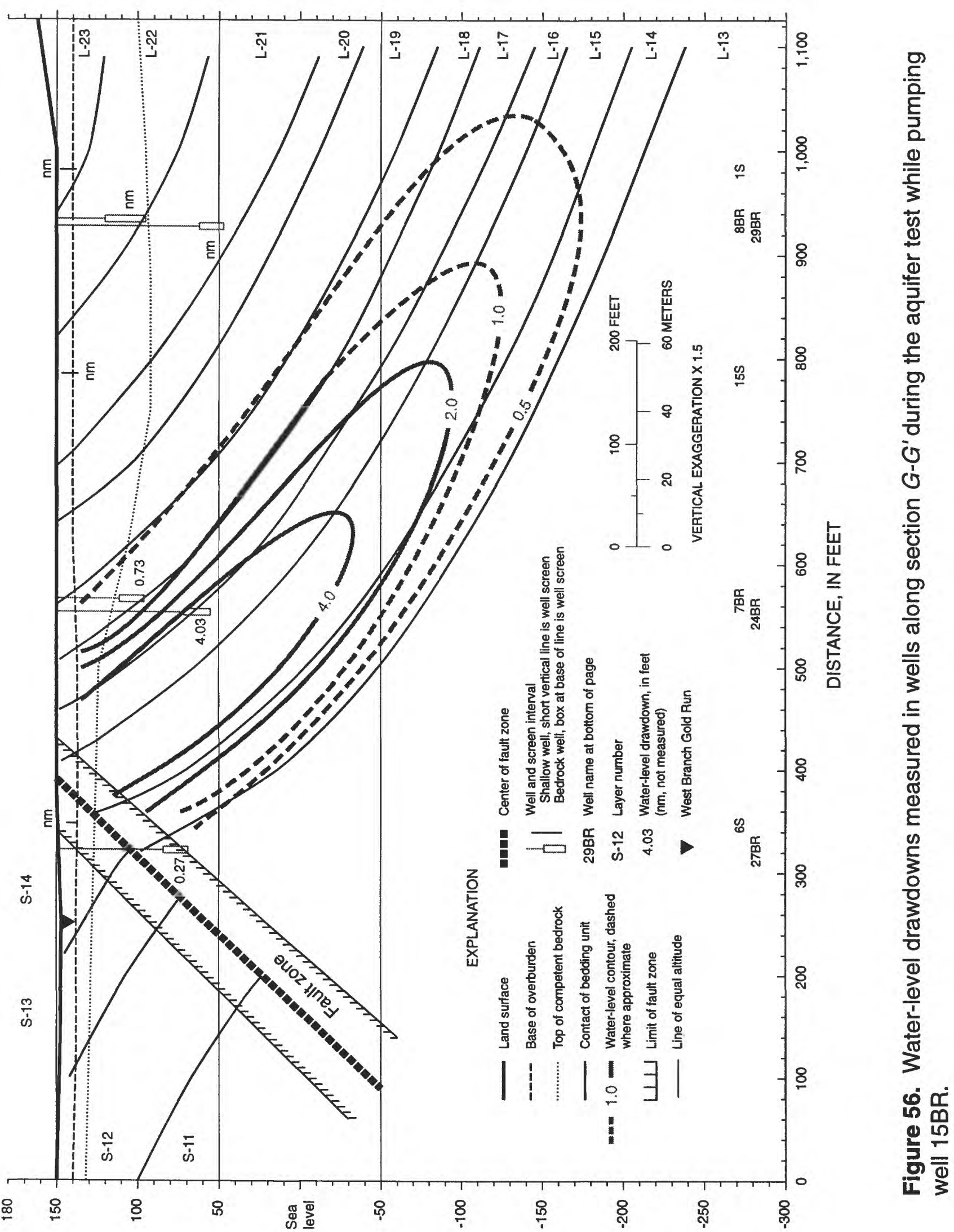


I

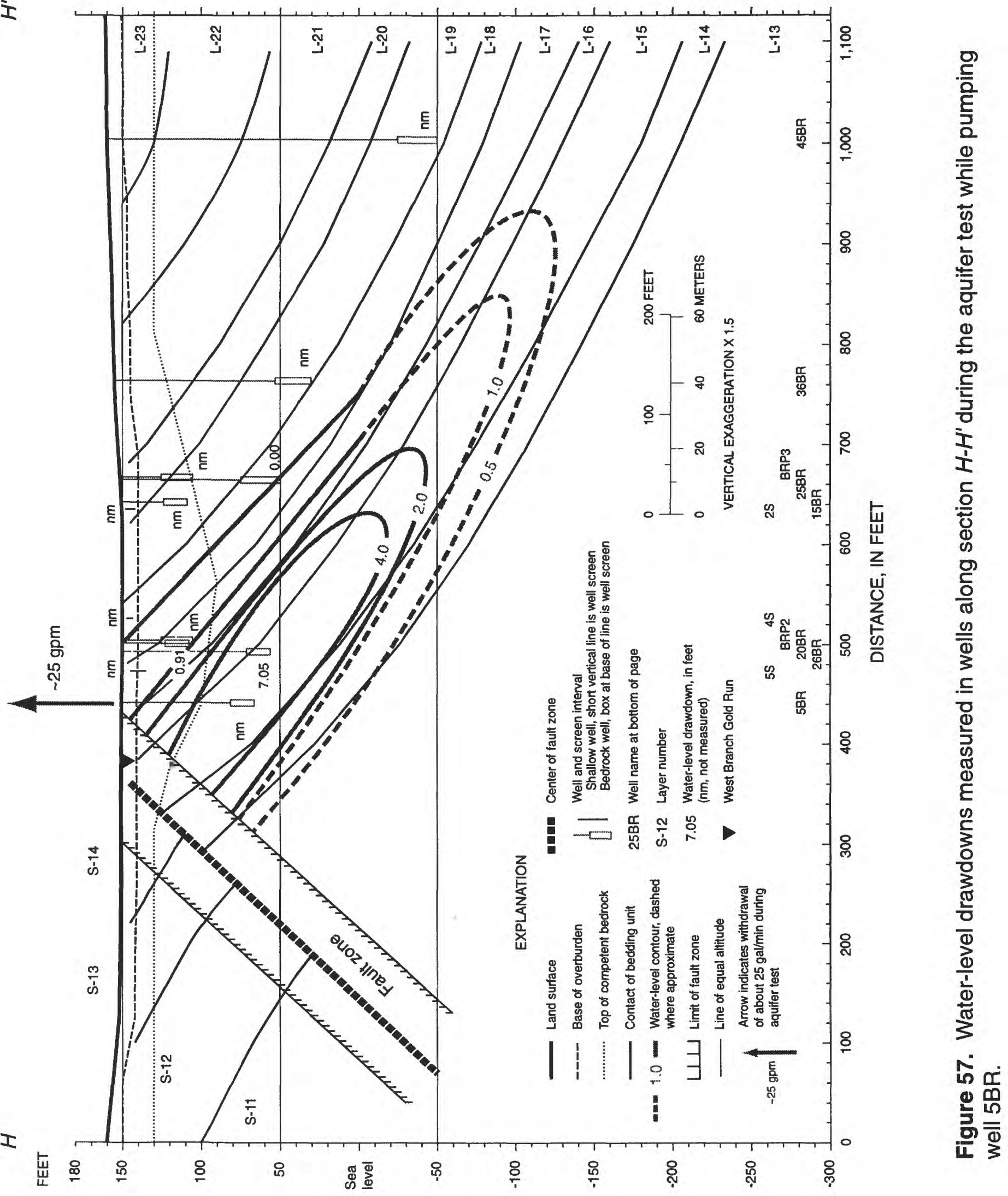


exceptionally low hydraulic conductivity; therefore, it should not respond to pumping. Because there was no drawdown in well $25 \mathrm{BR}$, the water levels in wells screened above bedding unit L-18 did not respond to the pumping test.

The water level declined $0.09 \mathrm{ft}$ in well 22BR, but this decline in water level in the Stockton aquifer is not necessarily the result of the aquifer test. Water levels in well 34BR increased $0.06 \mathrm{ft}$ during the aquifer test, but the increase is interpreted to be the result of an unknown factor other than the aquifer test.

Drawdown maps (figs. 52 and 53) show that the center of the zone of greatest drawdown stayed in bedding units L-15 and L-16. The drawdown along strike and at an altitude of $+150 \mathrm{ft}$ (about land surface) is about 10 times greater than the drawdown perpendicular to the strike of the bedding. Therefore, the anisotropy ratio is 10:1 for the shallow part of the Lockatong aquifer near well 5BR. In contrast, the drawdown along strike and at an altitude of $+50 \mathrm{ft}$ (about $100 \mathrm{ft}$ below land surface) is about 4 times greater than the drawdown perpendicular to the strike of the bedding. Therefore, the anisotropy ratio is $4: 1$ for the deeper part of the Lockatong aquifer. The drawdown map for bedding units $\mathrm{L}-15$ and $\mathrm{L}-16$ is based on values from three wells (fig. 54). Drawdown along strike is shown to be nearly identical to drawdown that is down dip. As a result, bedding units L-15 and L-16 are nearly isotropic with a ratio of about 1:1. The 10:1 ratio of anisotropy for the shallow bedrock near well 5BR is a result of the relatively steep bedrock dip, about $65^{\circ}$ to $70^{\circ}$, and the proximity of the pumped well to the fault zone. At a depth of about $100 \mathrm{ft}$ the bedrock dip is shallower, about $40^{\circ}$, and the fault zone is farther away.

\section{Summary of Aquifer Test Data Analyzed for Drawdown}

The three aquifer tests show that the
Lockatong aquifer is anisotropic and that the dip of the bedrock controls the anisotropy of the aquifer. The greater the dip, the greater the anisotropy of the aquifer. However, individual water-bearing zones are more isotropic than the aquifer to a depth of about $200 \mathrm{ft}$ below land surface.

In addition, more water is available in storage in the shallow parts of each bedding unit because of a high fracture density and/or because the bedding units are less permeable in the shallow parts. Therefore, the areal extent of the cone of depression is less in the shallow part of the bedding units than in the deep part of the bedding units.

\section{Stressed Water Levels During Operation of the Recovery Well}

Stressed water levels were measured in all wells at the NAWC during August 25-27, 1997 , during the operation of the recovery well for the pump and treat facility. The water-level maps and sections show the cone of depression in conjunction with the hydraulic gradient of the region (figs. 58 to 68 ). Well $15 \mathrm{BR}$, the recovery well screened in bedding unit L-19, was pumped at a rate of about 15 to 18 $\mathrm{gal} / \mathrm{min}$. The pump was operated for 3 months or more prior to water-level measurements.

The cone of depression created by the pumped well extends from bedding units L-17 to L-21. At land surface, the cone of depression extends from the West Branch of Gold Run to the east end of Building 41 (fig. 58). The water-level mound that lies inside the 144- $\mathrm{ft}$ contour east of the cone of depression is an area of unstressed water levels similar to water levels measured in 1995 (fig. 28). This mound shows that drawdown is limited in bedding units L-17 and L-18 in this area as a result of pumping of well $15 \mathrm{BR}$.

The cone of depression at an altitude of $+50 \mathrm{ft}$ (about $100 \mathrm{ft}$ below land surface) remains centered in bedding units L-17 to 


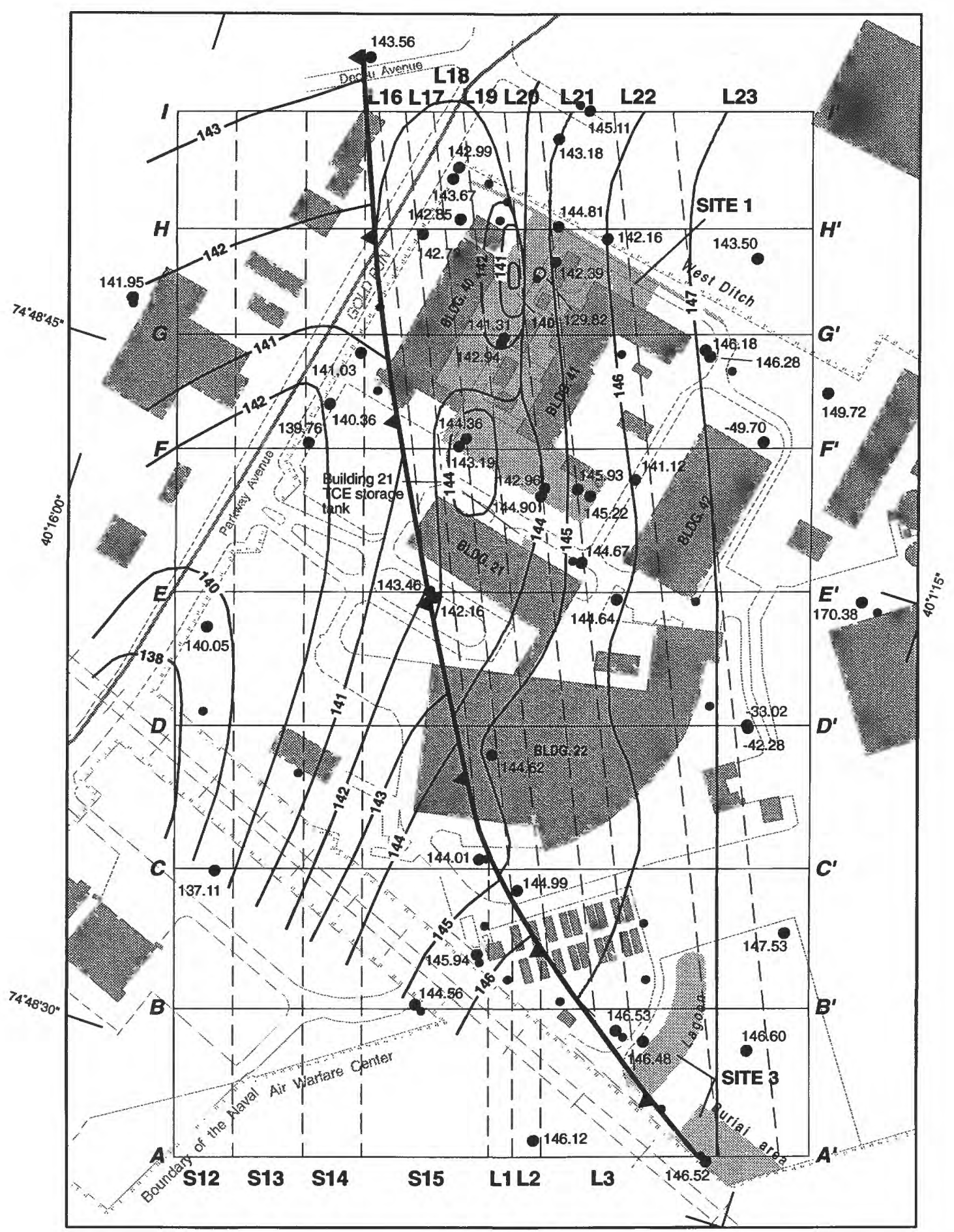

EXPLANATION

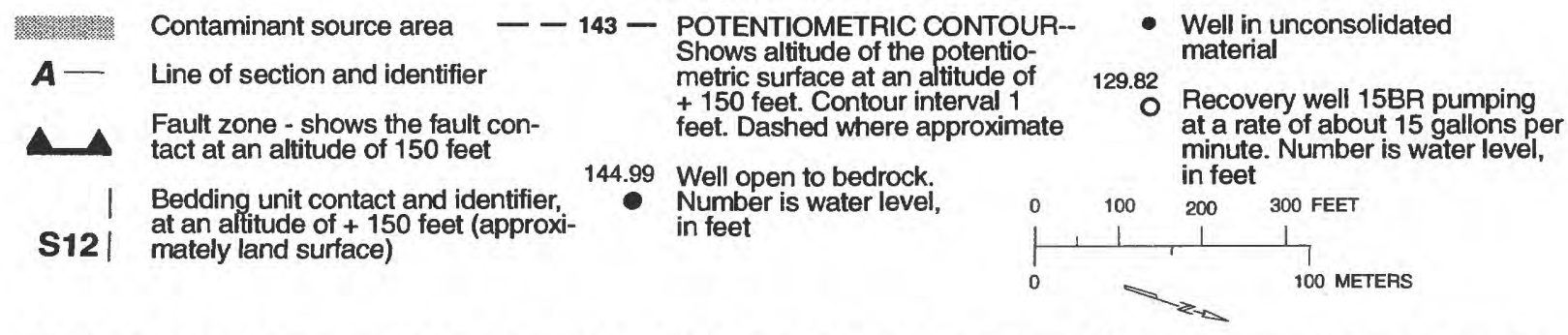

Figure 58. The stressed potentiometric surface in August 1997 shown at an altitude of 150 feet (approximately land surface), Naval Air Warfare Center, West Trenton, N.J. 


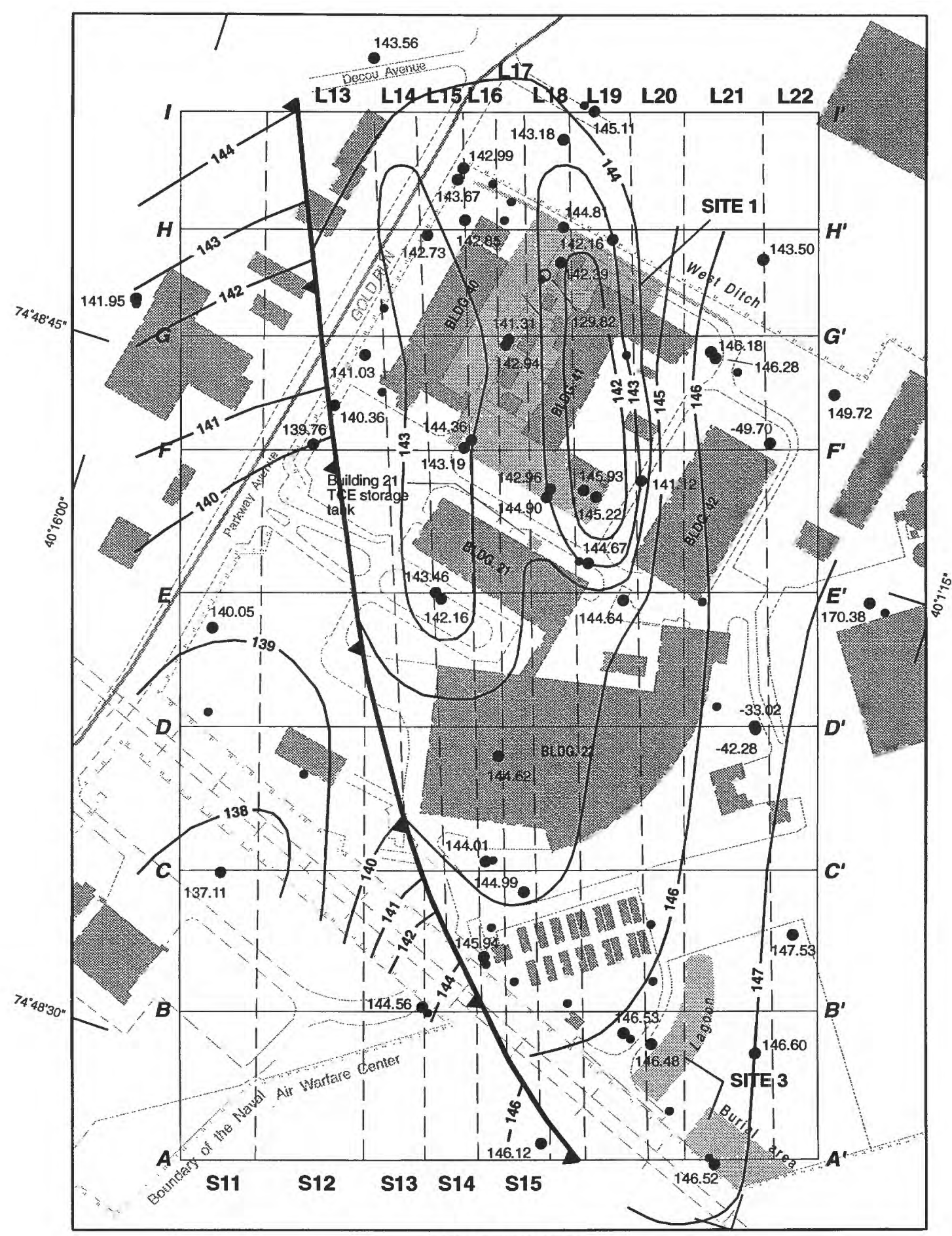

EXPLANATION

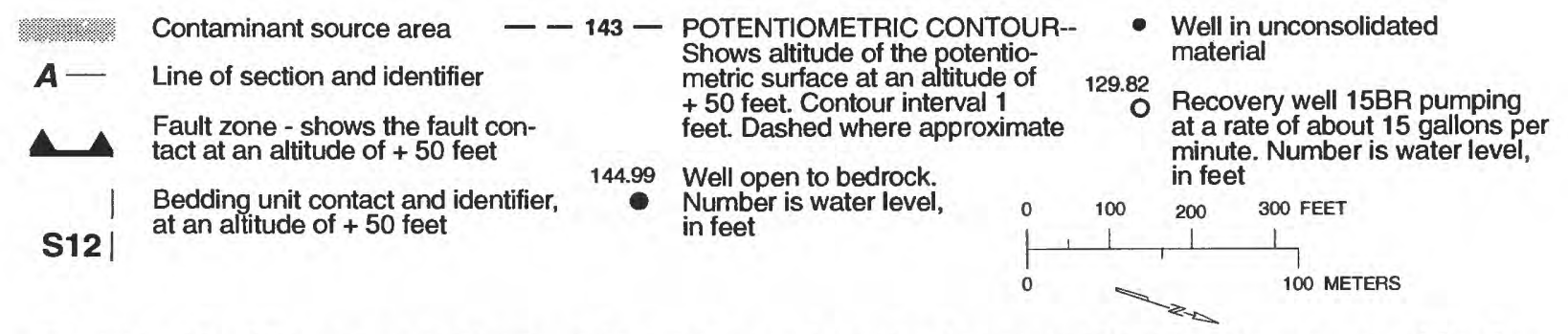

Figure 59. The stressed potentiometric surface in August 1997 shown at an altitude of +50 feet (approximately 100 feet below land surface), Naval Air Warfare Center, West Trenton, N.J. 
i

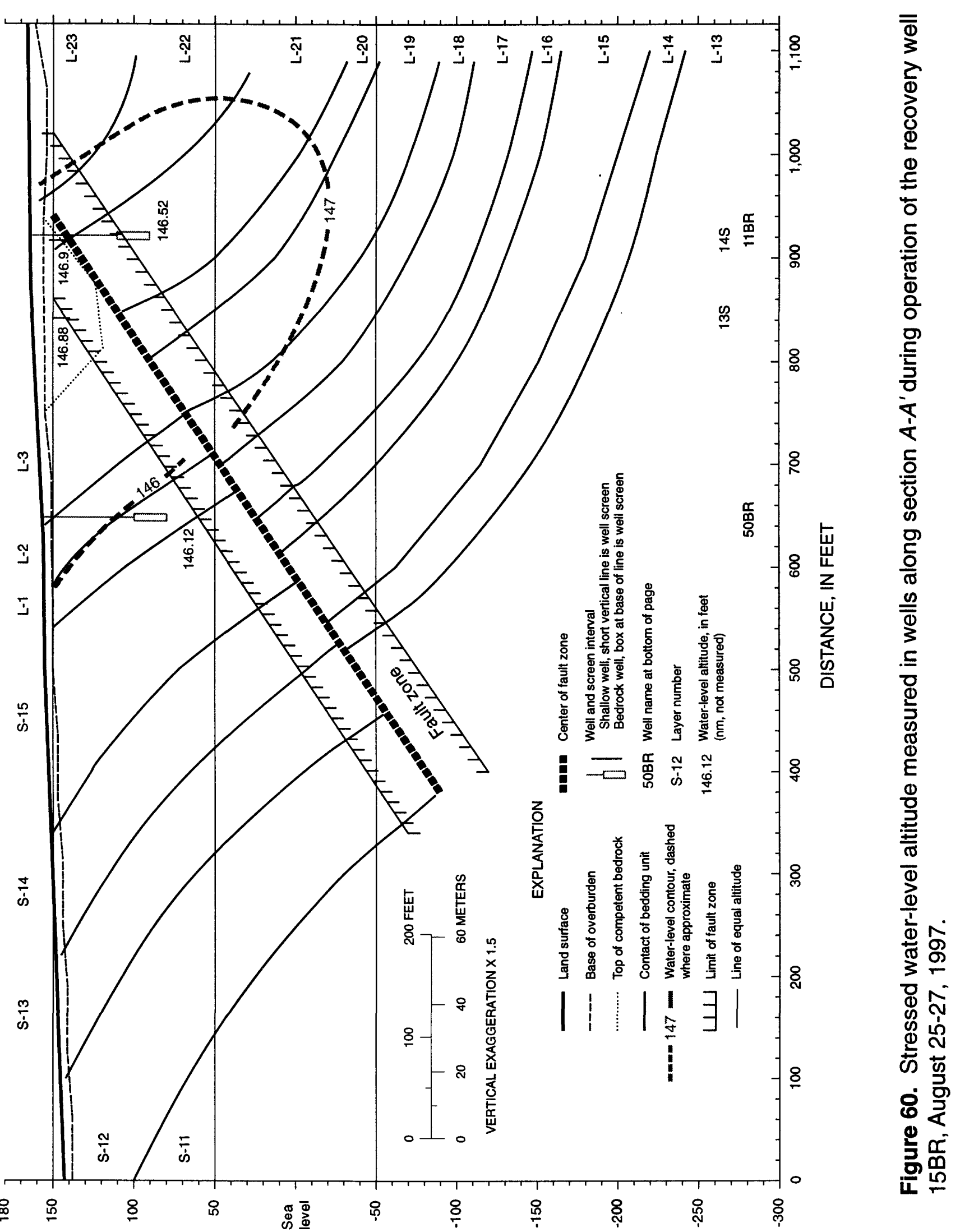




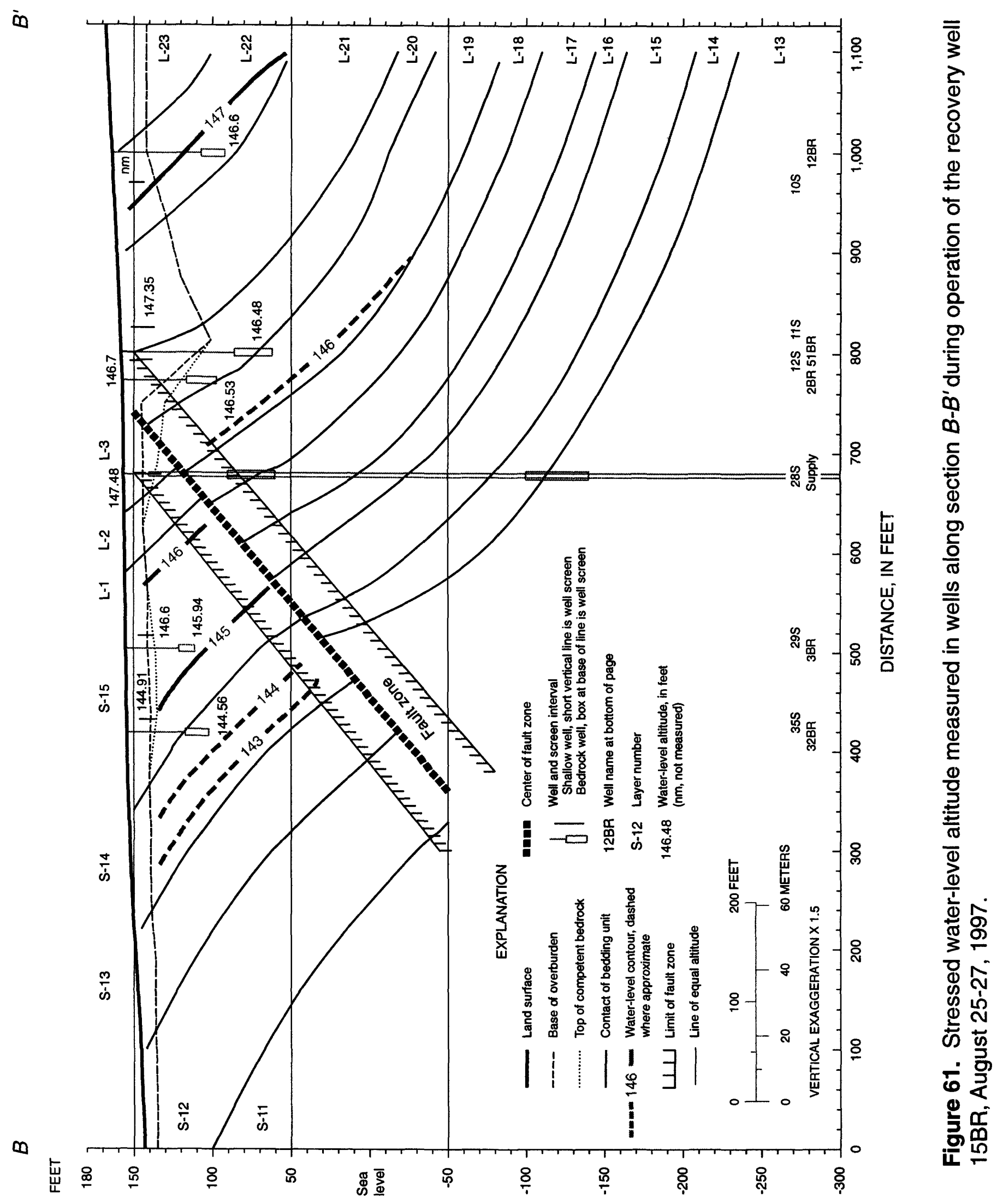


¿

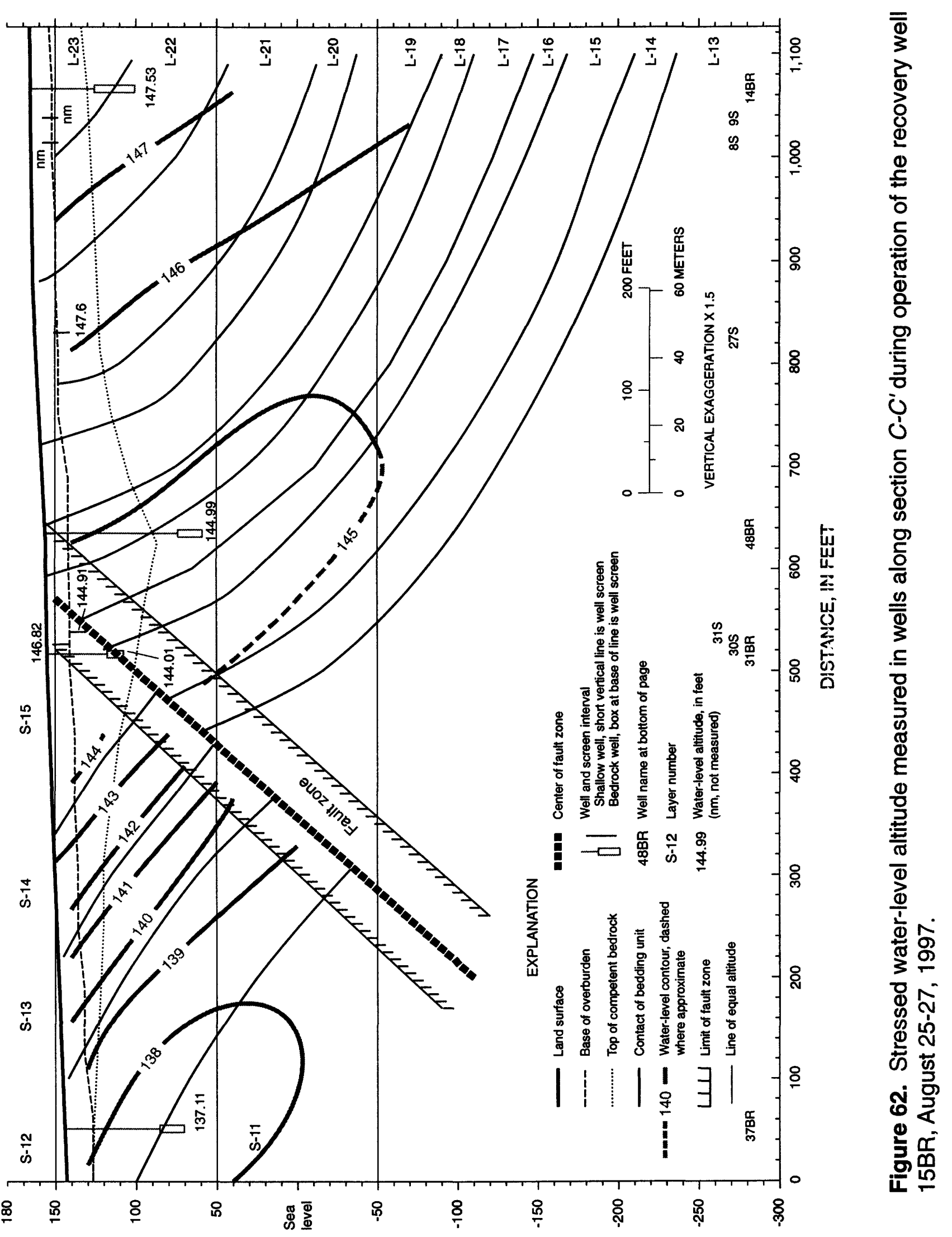




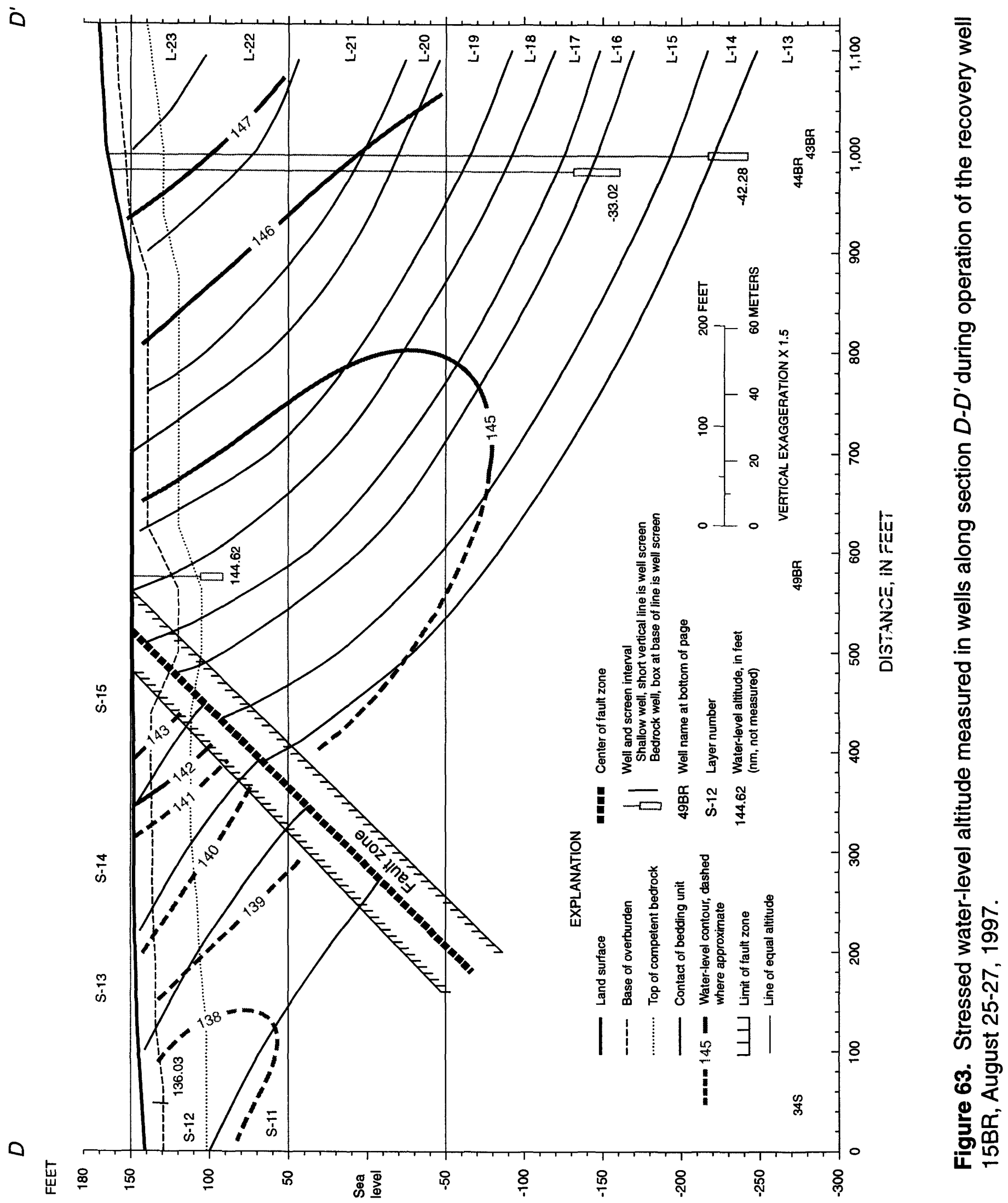


iu

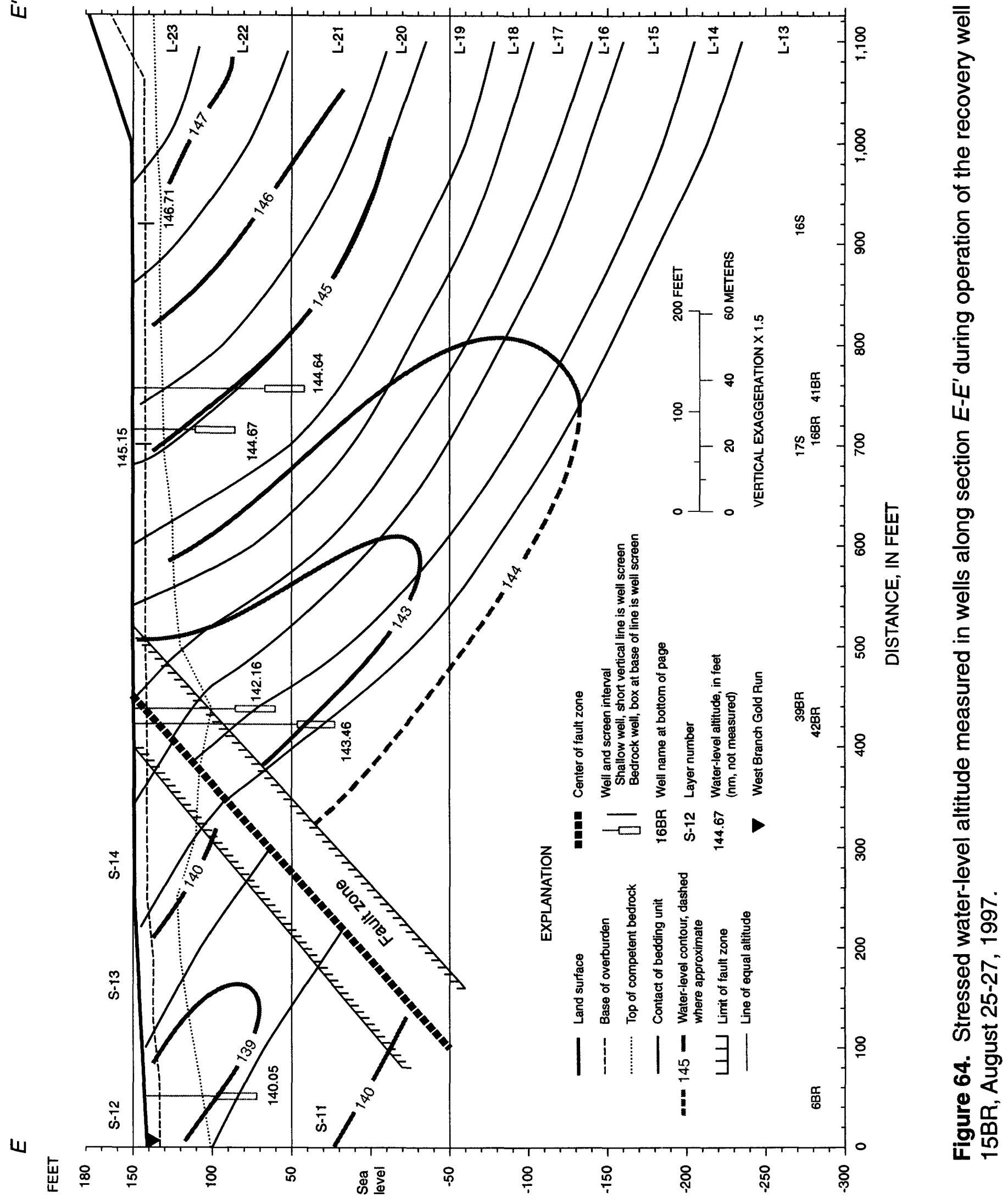




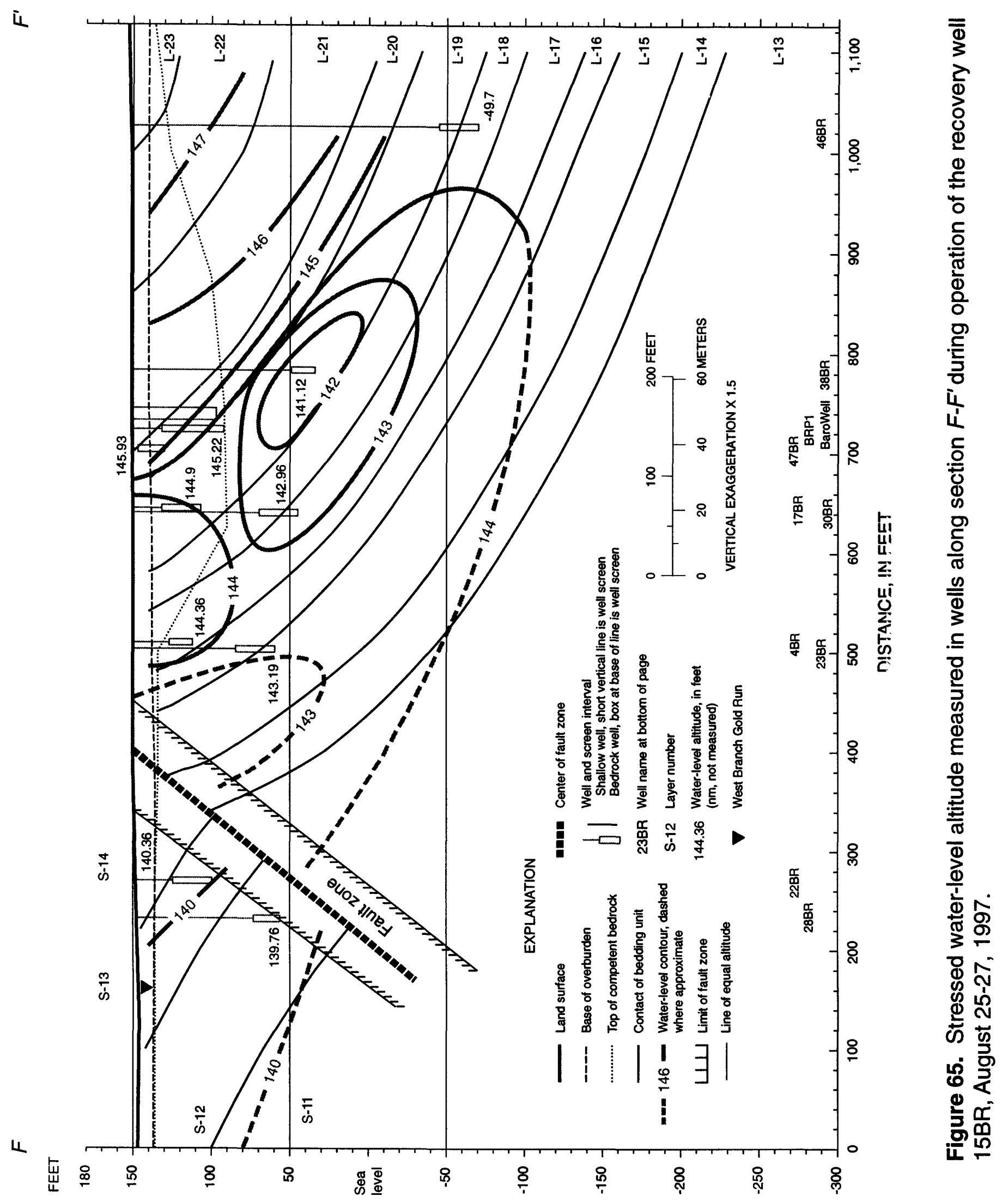


তু

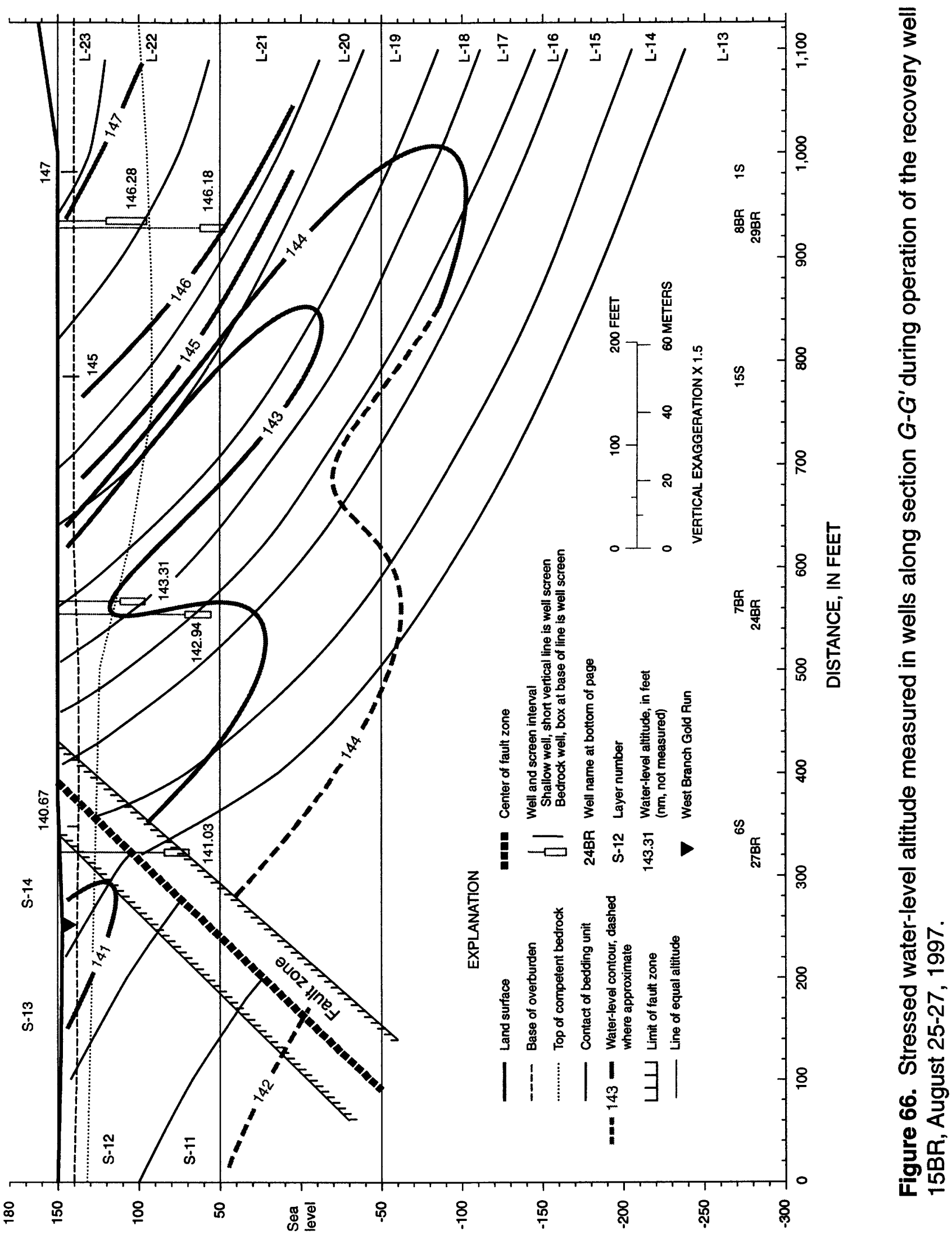




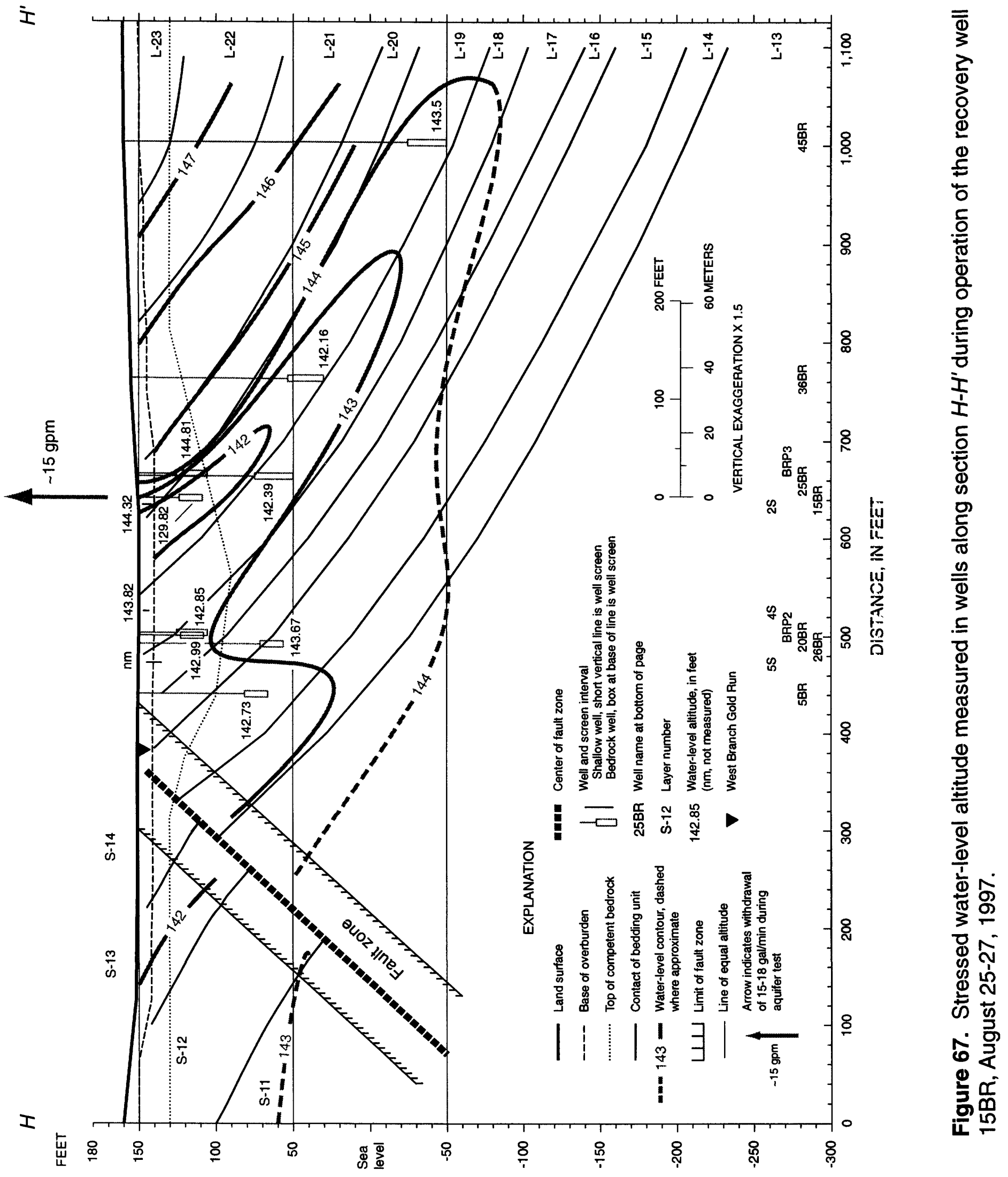




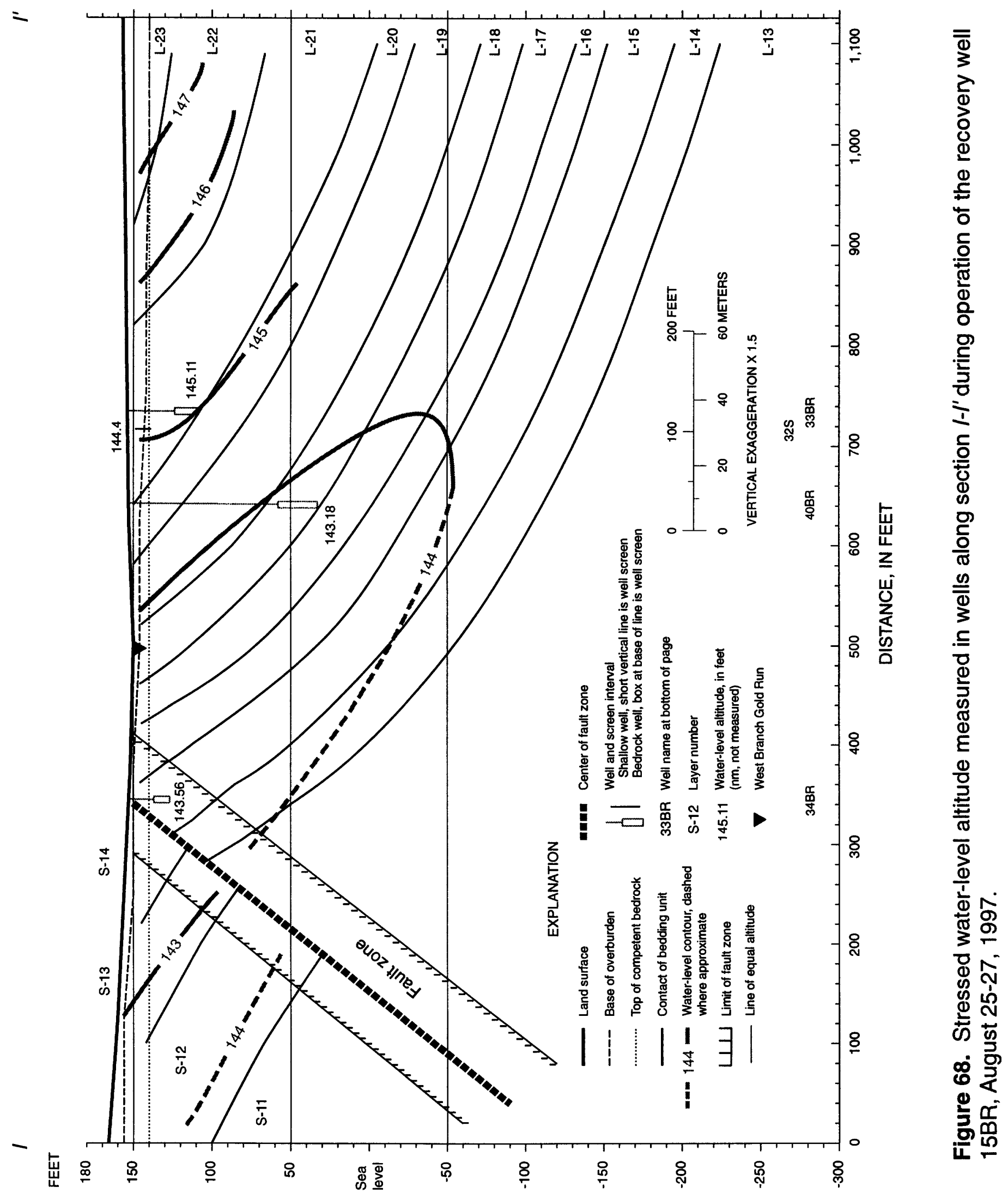


L-21. It extends westward to the West Branch of Gold Run and eastward about $200 \mathrm{ft}$ further to well 41BR (fig. 59). The fact that the cone does not expand further west beyond the West Branch of Gold Run indicates that sufficient water is supplied by the West Branch of Gold Run to supply the stressed system from that direction. The fact that the cone of depression expands farther eastward indicates that water must come from areas along the zone of greatest hydraulic conductivity. The closed 143-ft contour south of the cone of depression and centered on bedding unit L-15 (fig. 59) is a subtle modification of water levels as measured under static conditions (fig. 29).

In section E-E', (fig. 64) the hydraulic gradient is upward from well 42BR to 39BR as shown in figure 5. Water levels in well 6BR are above land surface and the hydraulic gradient is toward the West Branch of Gold Run. In section F-F' (fig. 65) the contours show the hydraulic gradient is toward bedding unit L-19; this indicates that flow is affected by the cone of depression created by pumping well $15 \mathrm{BR}$. The water-level altitude in well 46BR is $-49.7 \mathrm{ft}$ or about $150 \mathrm{ft}$ below land surface. Water levels did not recover in the 3 months after completion of drilling, development, and sampling of the well. As a result, the hydraulic conductivity of bedding units L-18 and L-19 is very low at this depth. The water level in well 38BR is the lowest of all wells in the cone of depression, with the exception of the pumped well. There is a very direct contact between wells 15BR and 38BR. Water levels in wells 23BR and 4BR show a downward hydraulic gradient, which indicate that the ground-water flow in this area is not toward the cone of depression caused by pumping, but rather is toward the natural hydraulic low in bedding unit L-15 caused by ground-water discharge westward to the West Branch of Gold Run. Water levels in wells 22BR and 28BR show southeastward and upward flow to the West Branch of Gold Run.
Section G-G' (fig. 66) shows that the hydraulic gradient in bedding units L-2i. and L-21 is downward as determined from vater levels in wells 8BR and 29BR. The hydraulic gradient in bedding units L-19 is shown to be updip because of water-level data shown in sections F-F' and H-H'. The hydraulic gradient is interpreted to be downward in bedding units L-16 to L-18 based on water levels in wells $7 \mathrm{BR}$ and 24BR. Flow in bedding unit L-15 is interpreted to be westward (into the pag?) as discussed earlier. In section H-H' (fig. 67), the hydraulic gradient in bedding units L-17 to L-22 is towards the cone of depression, which is centered on well 15BR and in bedding unit $\mathrm{L}-19$. Water levels in wells $45 \mathrm{BR}, 36 \mathrm{BF}$, and $15 \mathrm{BR}$ are $143.50,142.16$, and $129.83 \mathrm{ft}_{\text {. }}$ respectively. This indicates an updip hydraulic gradient in bedding unit L-19. Water levels in wells 20BR, 26BR, and 5BR show a hydraulic gradient toward bedding unit L-15 and updip flow direction in bedding unit L-15.

Water level in wells 43BR and 44BR (line D-D') (fig. 63) did not recover after drilling, development, and water-quality sampling. The lack of recovery in bedding units L-13 to L-16 is either because (a) there is no outcrop of bedding units $L-13$ to $L-16$, or (b) the anuifer has a very low hydraulic conductivity at depths of $300 \mathrm{ft}$ below land surface and deeper. Bedding units L-13 to L-16 do not crop out along Section D-D' or in upgradient areas east and northeast of the wells. As a result, the only source of water is from vertical fractures. Because the predominant flowpath is alcng the bedding-plane partings and there are no bedding-plane partings that crop out to supply water from land surface in this area, the ee is poor recovery of water levels in these tvro wells. An alternative reason for low water levels is that the bedding-plane and vert: al partings in the Lockatong Formation have all but closed because of the high overburd $n$ pressures at depths of $300 \mathrm{ft}$. Therefore, the hydraulic conductivity of the Lockatong: 
aquifer is near zero at depth of $300 \mathrm{ft}$ and greater. In all likelihood the lack of recovery in these two wells is a combination of the two reasons.

The hydraulic gradients on the south side of the fault are toward the West Branch of Gold Run. This indicates that the West Branch of Gold Run is still an active stream and it behaves as a hydraulic divide. It is interpreted that shallow ground water on the base between the West Branch of Gold Run and the fault/ contact will discharge to the West Branch of Gold Run and will not cross underneath the stream.

In summary, the cone of depression caused by pumping well $15 \mathrm{BR}$ predominantly lowers water levels in bedding unit L-19.

However, the drawdown only extends from the West Branch of Gold Run about $500 \mathrm{ft}$ west of well 15BR to well $41 \mathrm{BR}$ about $500 \mathrm{ft}$ east of well 15BR. Pumping acts, to a lesser extent, to lower water levels in bedding units L-17, L-18, and L-20 to L-23. The recovery well may intercept contamination from other bedding units; however, the recovery well also may lower water levels in some wells but not change the hydraulic gradient or the flowpaths and therefore not capture the contamination. From a conservative viewpoint, contamination is being removed from the immediate vicinity of the recovery well especially in bedding units L-17 to L-20 but the pumping well may not be recovering water from other areas. Contamination in areas outside the capture zone of the pumped well will not be captured; however, contamination south of the cone of depression created by well $15 \mathrm{BR}$ will follow the natural flow gradient and may discharge to the West Branch of Gold Run.

\section{WATER QUALITY}

Water-quality samples have been collected on selected dates from the bedrock and over burden wells at the Naval Air Warfare Center since the first monitoring wells were installed in 1990. Water-quality data, including values of TCE, cis-DCE, and VC, were published in reports by International Technology Corporation, (July, 1994, table 4-1A and 4-1B), EA Engineering, Science, and Technology, Inc., (February, 1996, table 4-1; August, 1997, table 1).

Some wells were sampled many times, whereas other wells were sampled only once. TCE, cis-DCE and VC are discussed in that order, and their concentrations are shown in figures. Sections A, B, and C, which cross the Site 3 area are discussed first, followed by sections $\mathrm{D}$ and $\mathrm{E}$ between Sites 1 and 3. The two scenarios for Site 1, which is crossed by sections $\mathrm{F}, \mathrm{G}$, and $\mathrm{H}$, are discussed, and finally section I, which is west of Site 1, is discussed.

\section{Trichloroethylene (TCE)}

The two source areas for TCE contamination at the NAWC were first identified by International Technology Corporation (July 1994), as Site 1 and Site 3 (fig. 2). Site 1 is the brinehandling area and consists of the TCE storage and handling facilities between buildings 40 and 41, the network of above-ground TCE pipelines, waste lines that lead to the barometric well, and the West Ditch where TCEladen wastewater was disposed. Site 3 consists of a former wastewater lagoon and sludge disposal area. These areas are shown in the map view (figs. 69 to 71) and in the sections as lines at land surface (figs. 72,73 , and 77 to 80 ). In addition to the two areas identified above, a third source may exist. Building 21, a metal-working facility and a nearby TCE underground storage tank may be a site where TCE was used and stored during routine operations.

Because TCE was used at the NAWC for about 40 years, it is probable that some of it has been released aerially. There may be an 


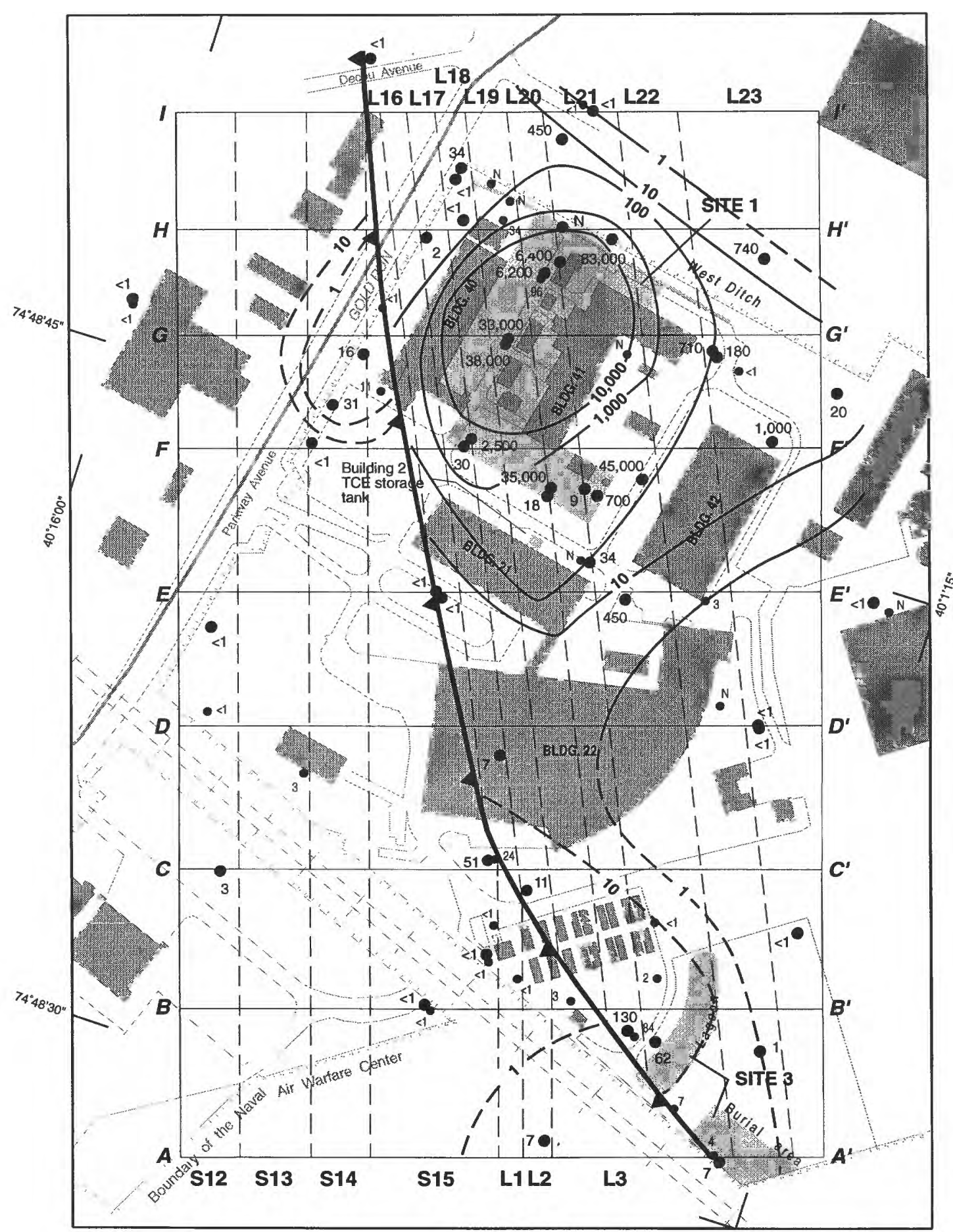

EXPLANATION

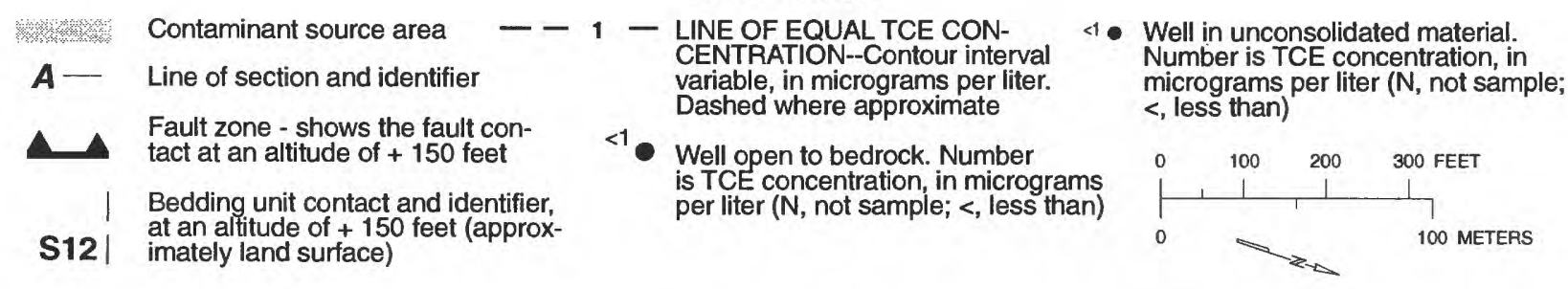

Figure 69. TCE concentrations, in micrograms per liter, in water samples from bedrock and shallow wells, June 1997, and contours for top of bedrock (an altitude of +150 feet and approximately land surface), scenario 1 and 2, Naval Air Warfare Center, West Trenton, N.J. 


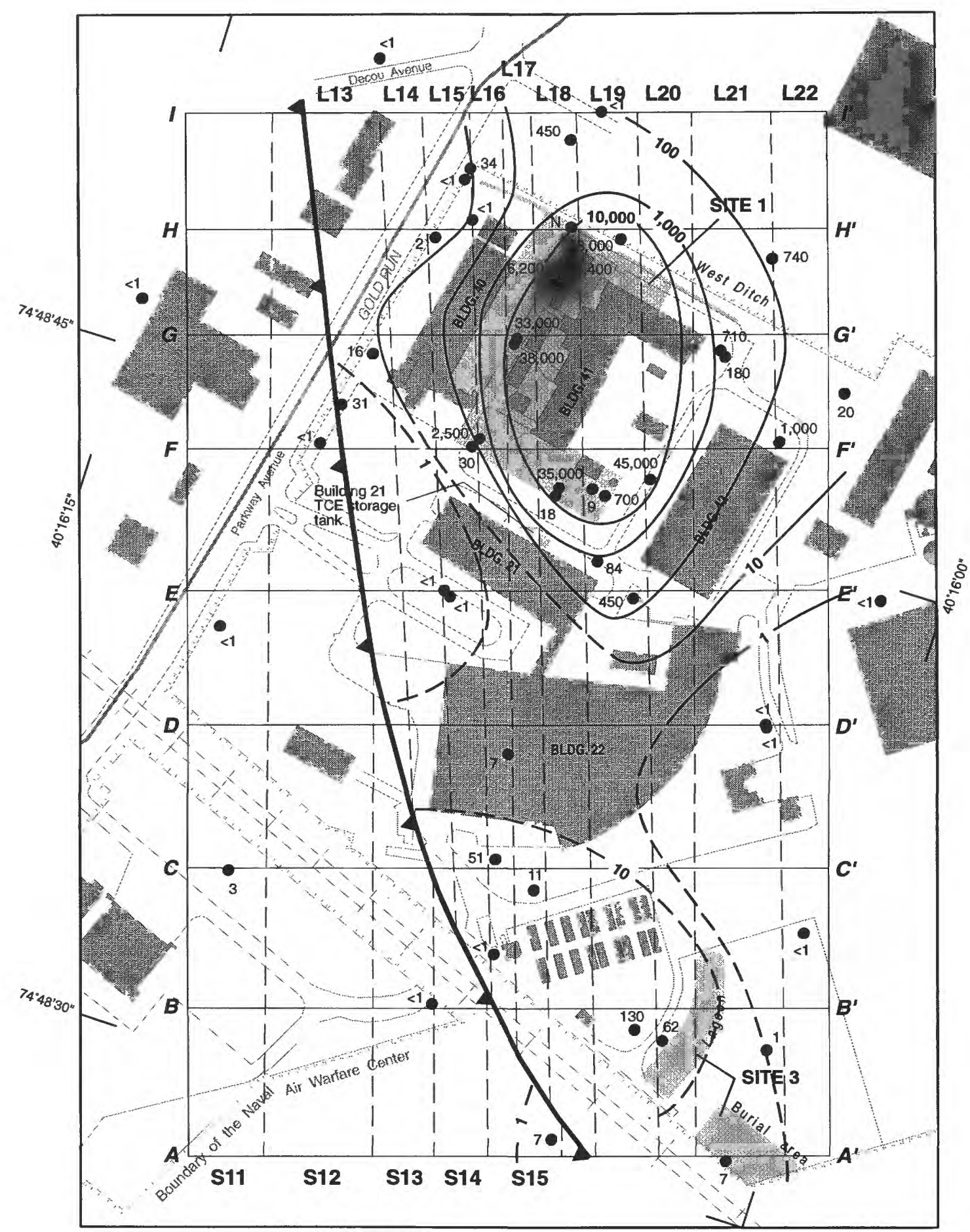

EXPLANATION

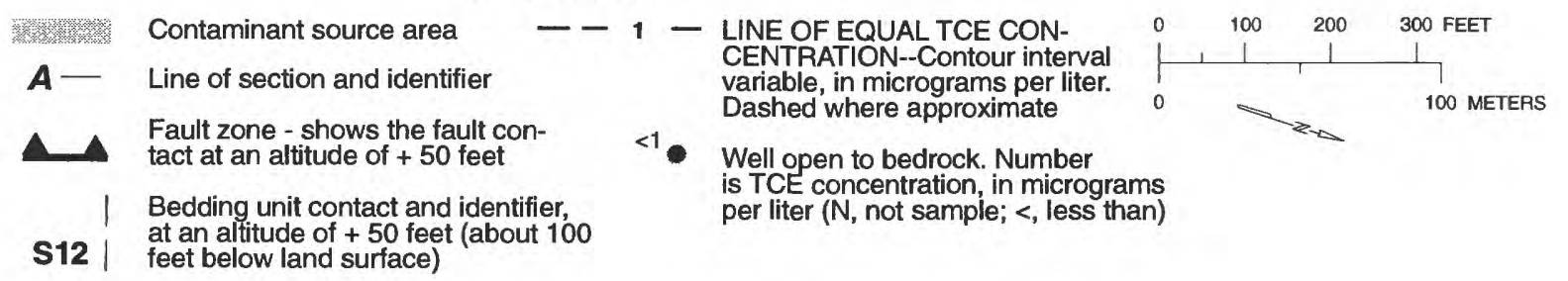

Figure 70. TCE concentrations, in micrograms per liter, in water samples from bedrock and shallow wells, June 1997, and contours for an altitude of +50 feet (about 100 feet below land surface), scenario 1 and 2, Naval Air Warfare Center, West Trenton, N.J. 


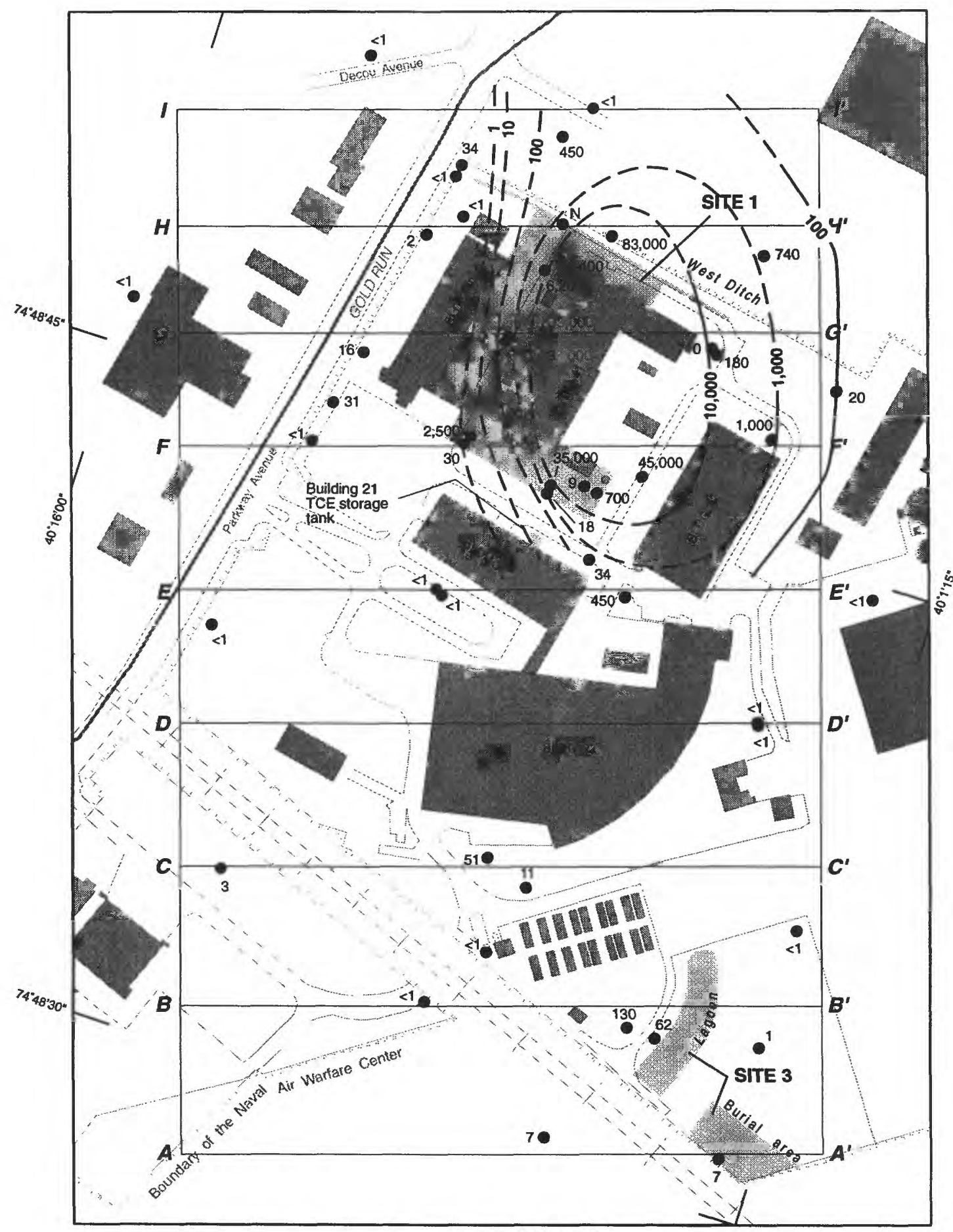

EXPLANATION

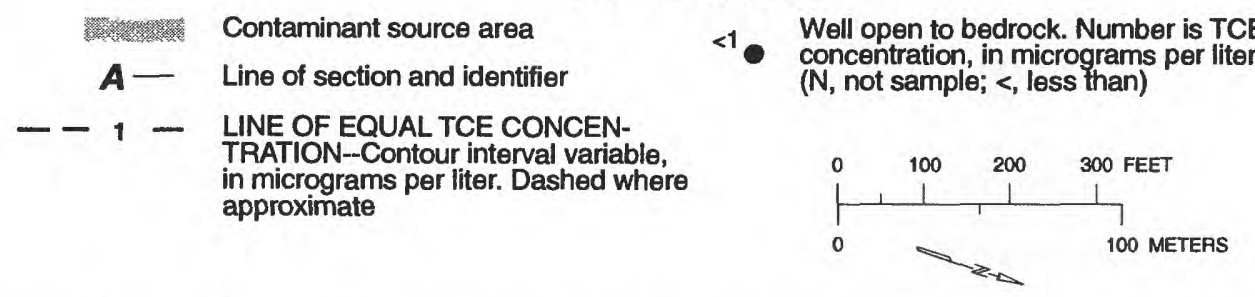

Figure 71a. TCE concentrations, in micrograms per liter, in water samples from bedrock wells, June 1997, and contours for an altitude of - 50 feet (about 200 feet below land surface), scenario 1, Naval Air Warfare Center, West Trenton, N.J. 


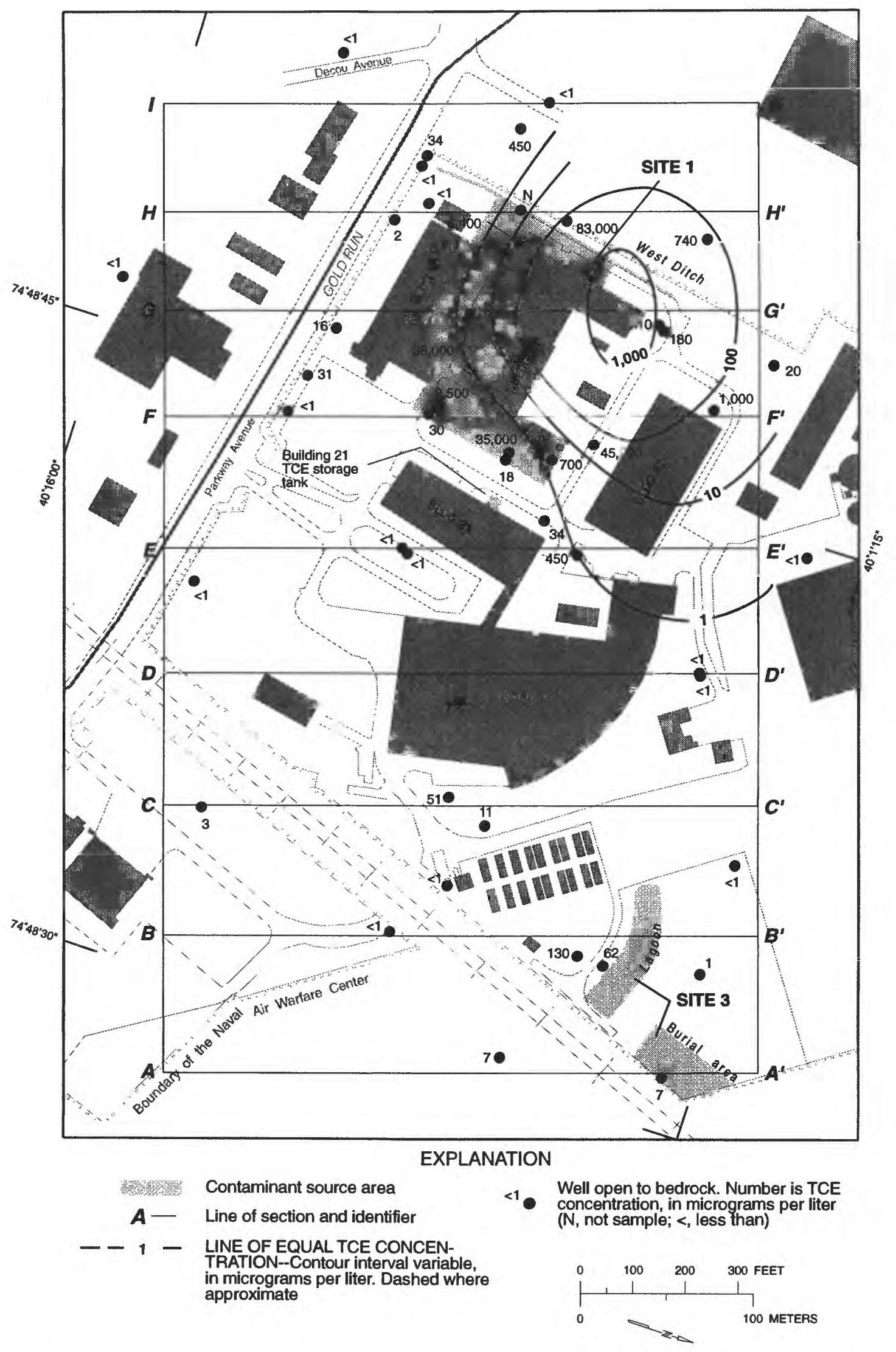

Figure 71b. TCE concentrations, in micrograms per liter, in water samples from bedrock wells, June 1997, and contours for an altitude of - 50 feet (about 200 feet below land surface), scenario 2, Naval Air Warfare Center, West Trenton, N.J. 
广

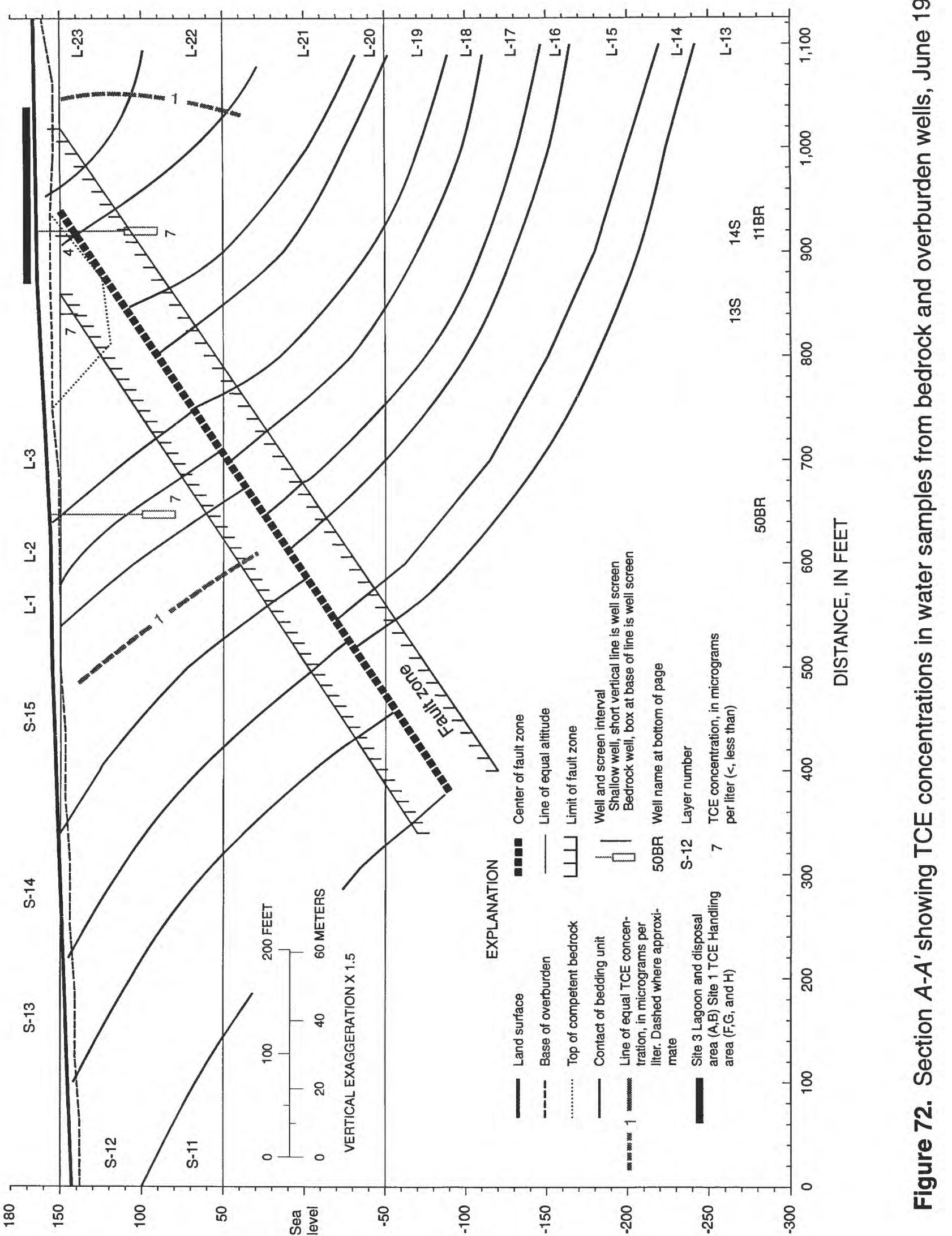


in

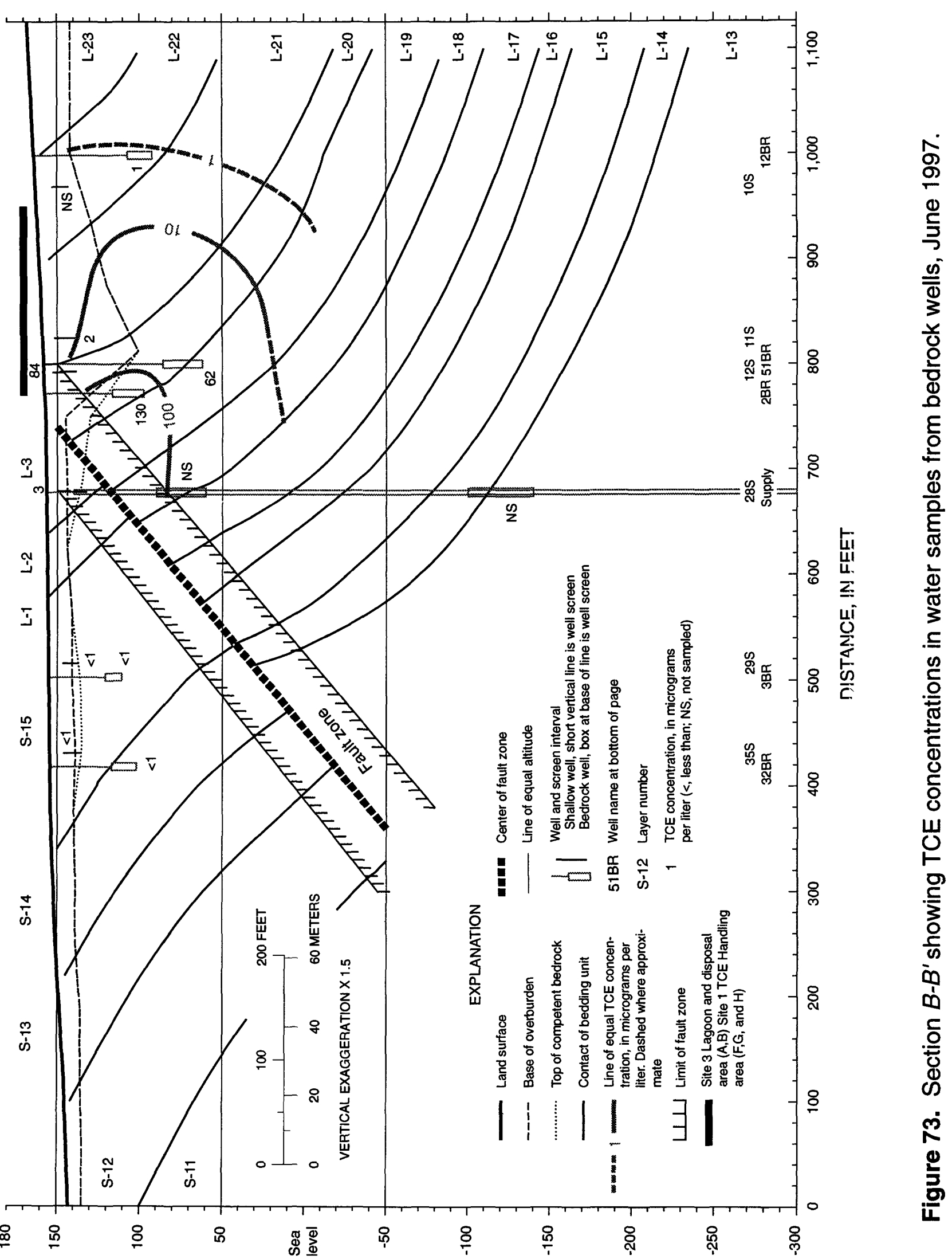


i

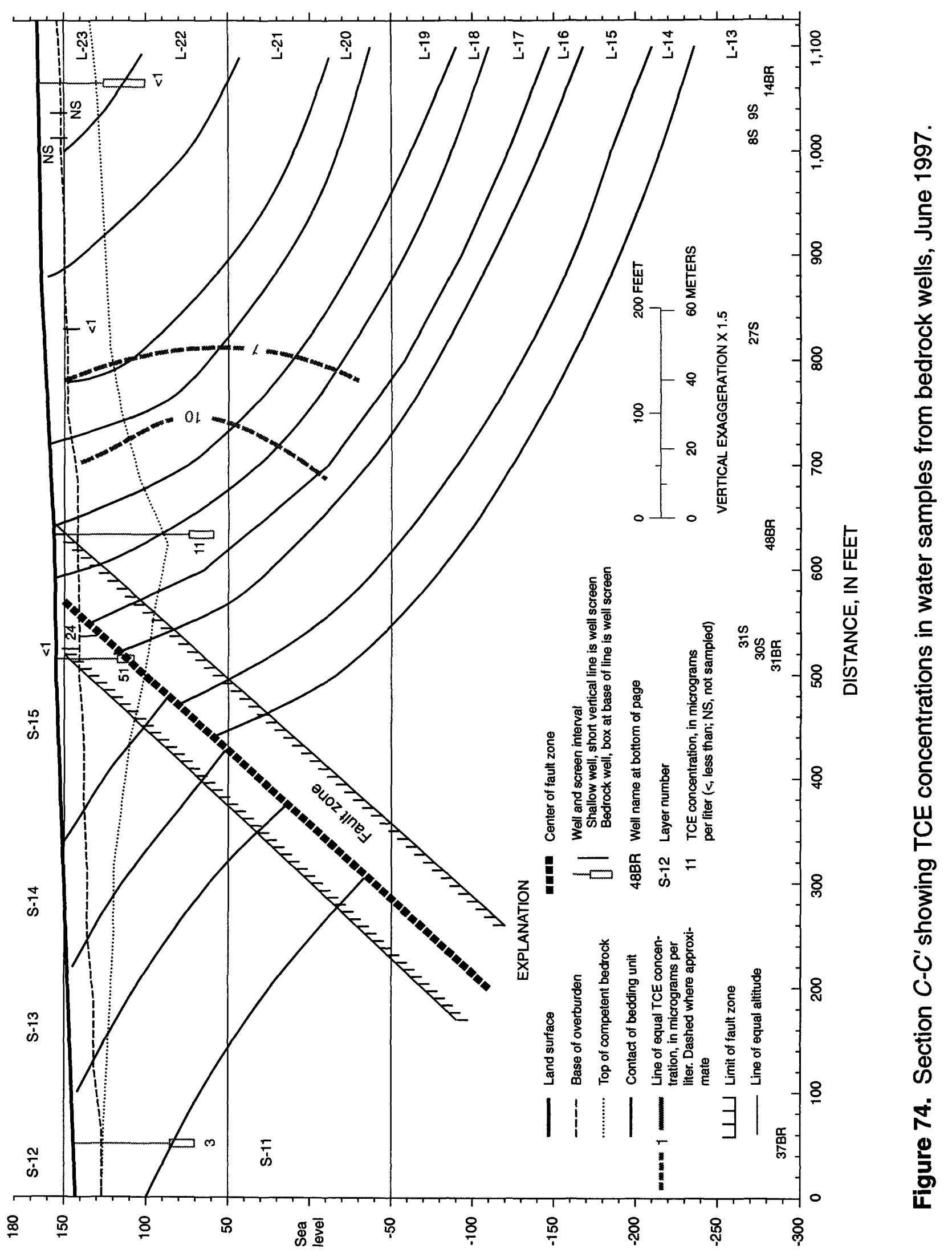


o

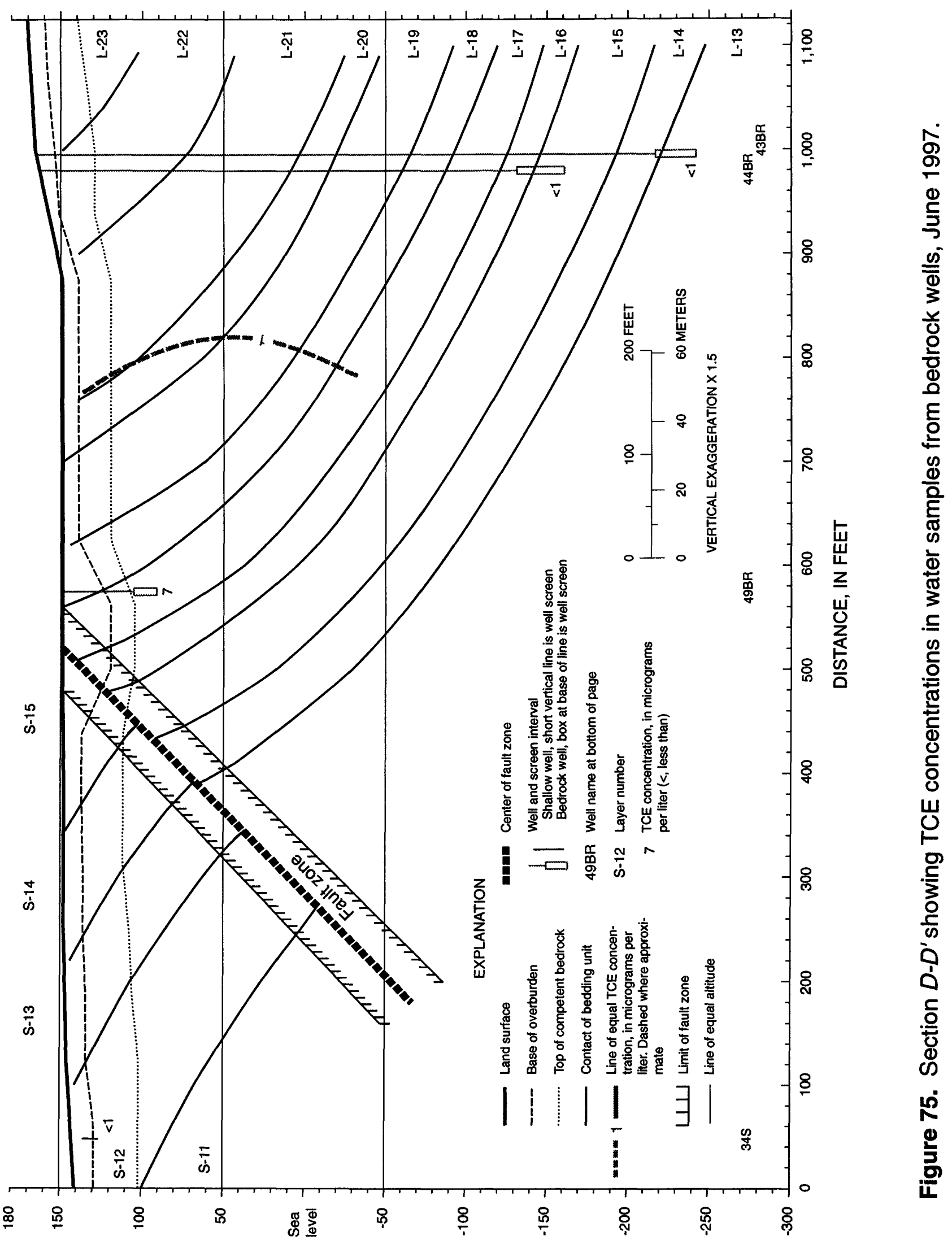


这

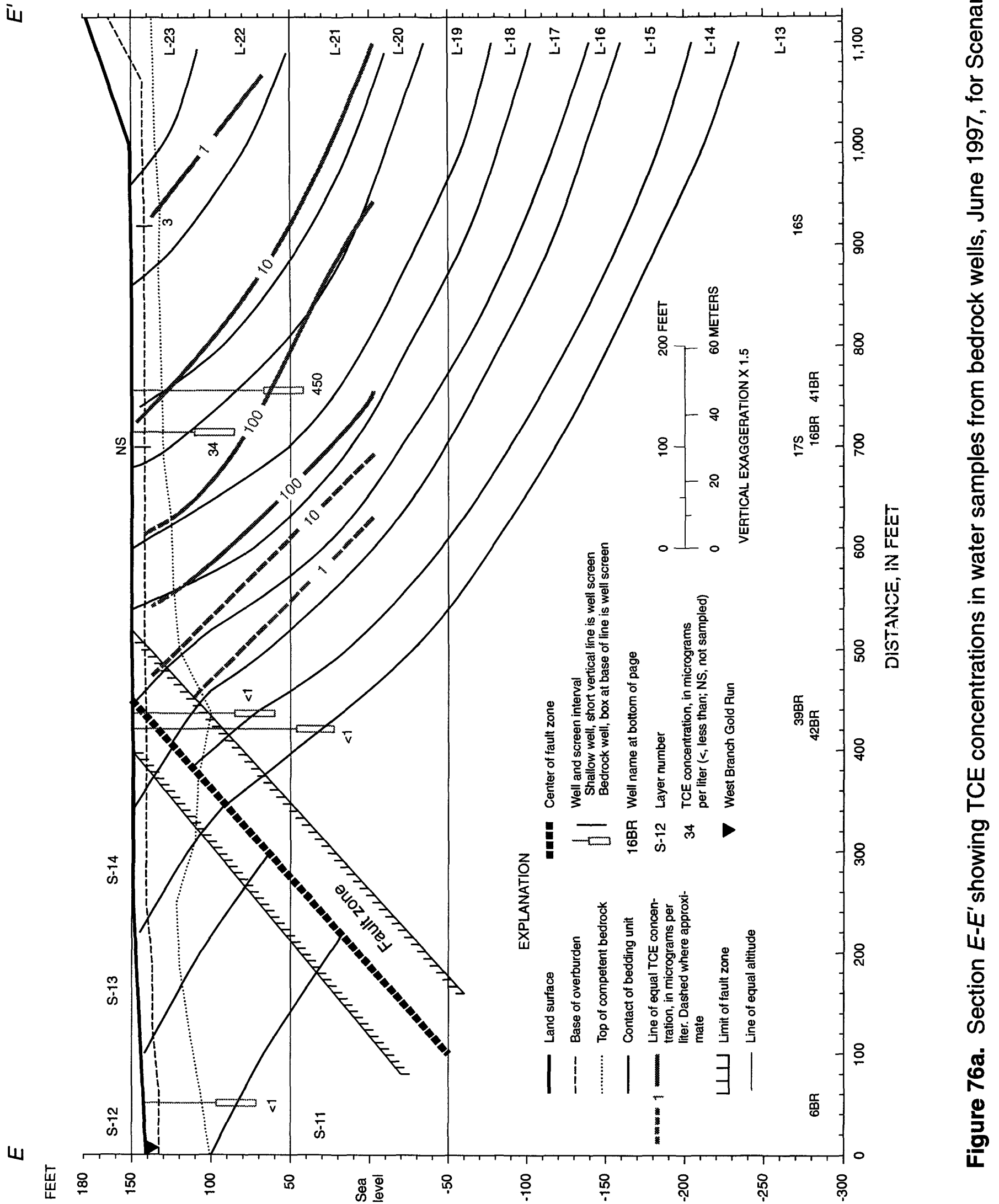


iv

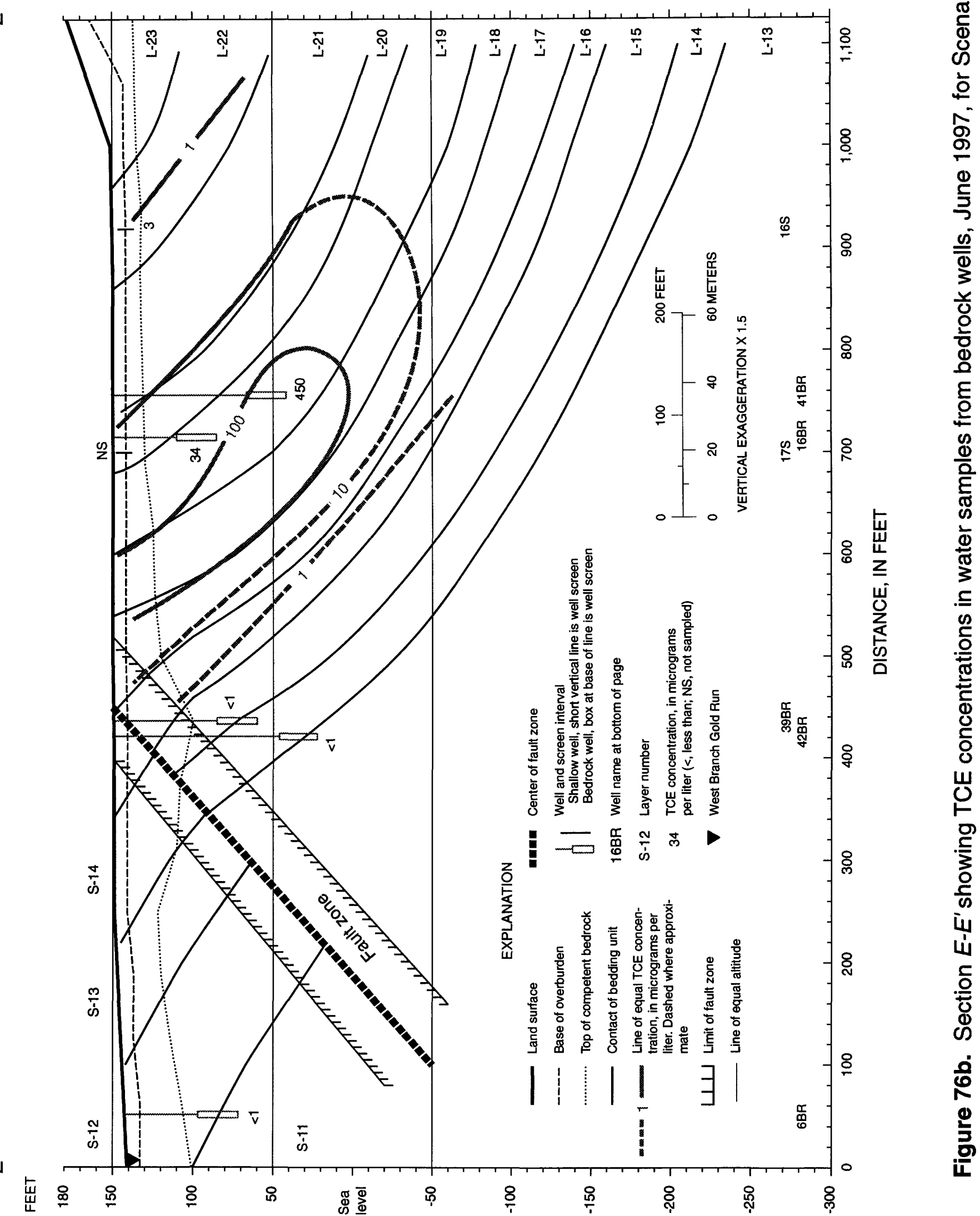


is

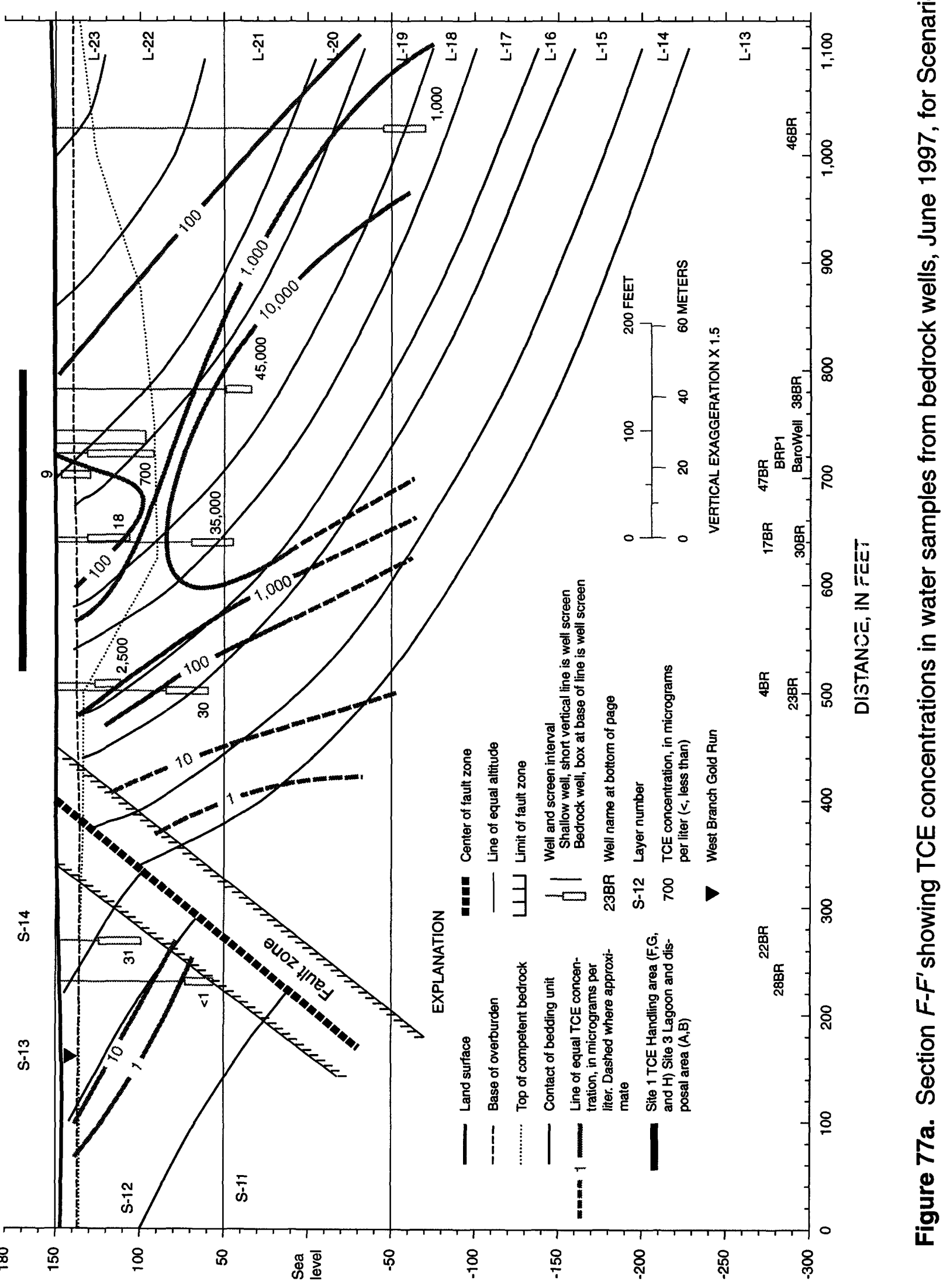


ir

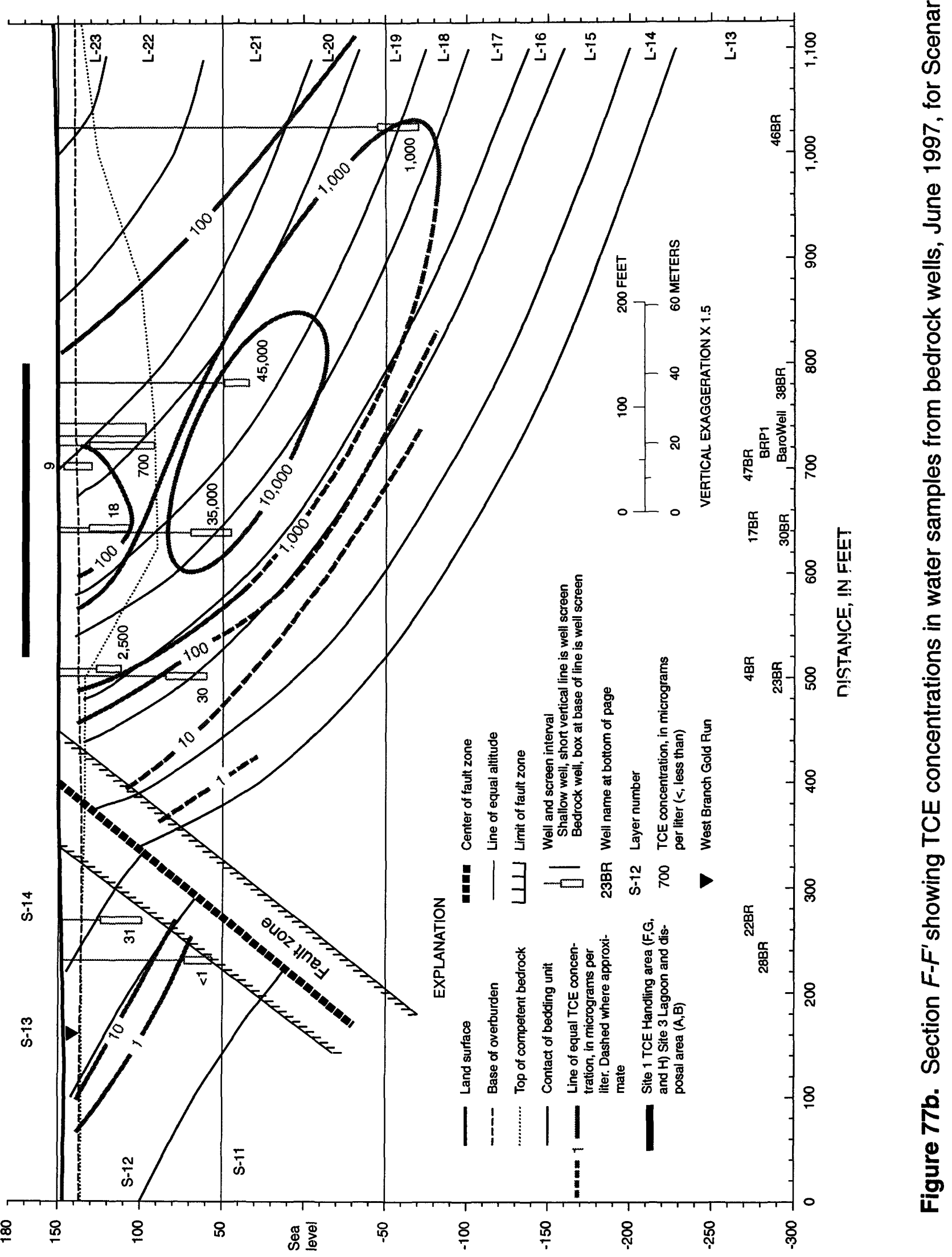


ì

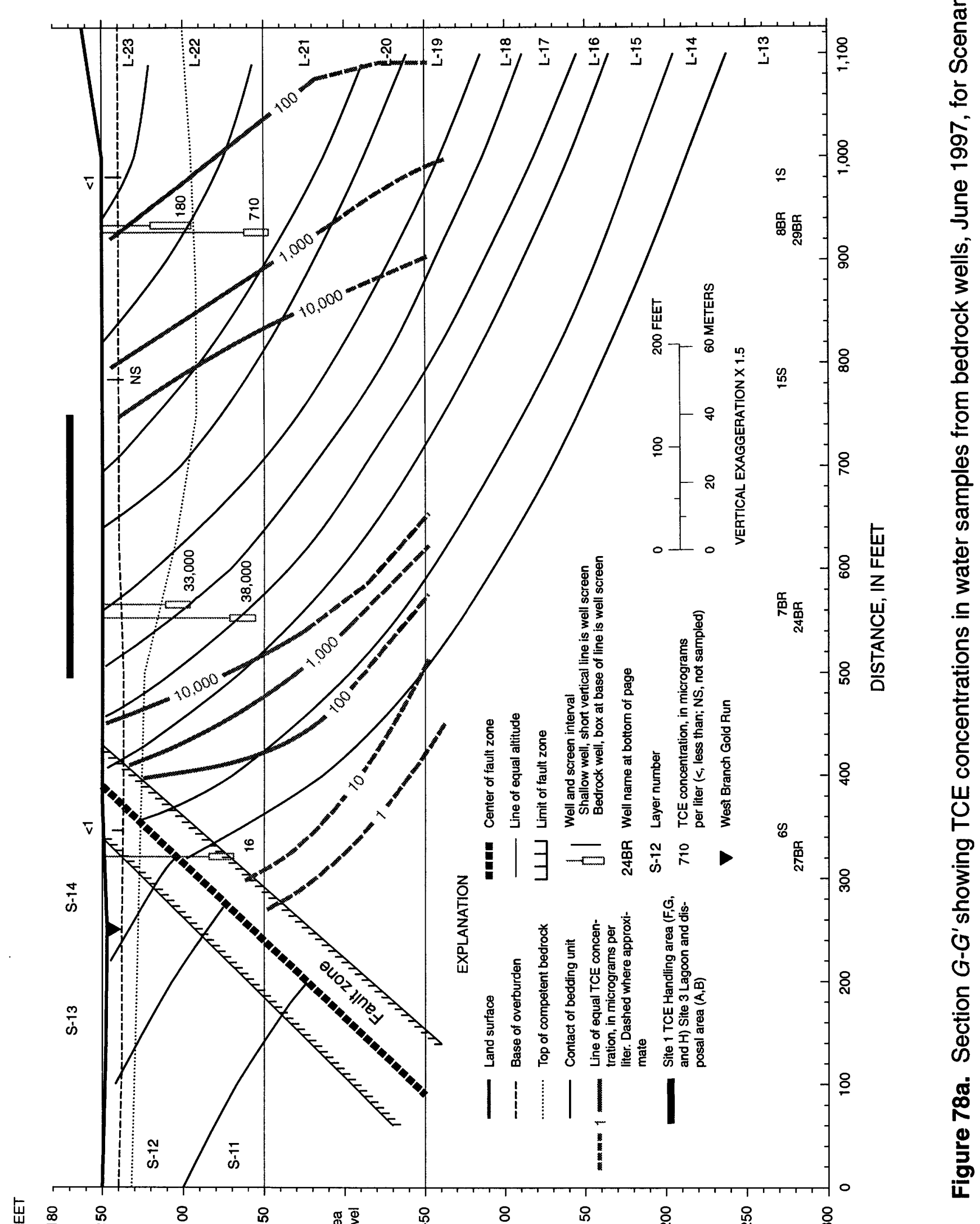


তু

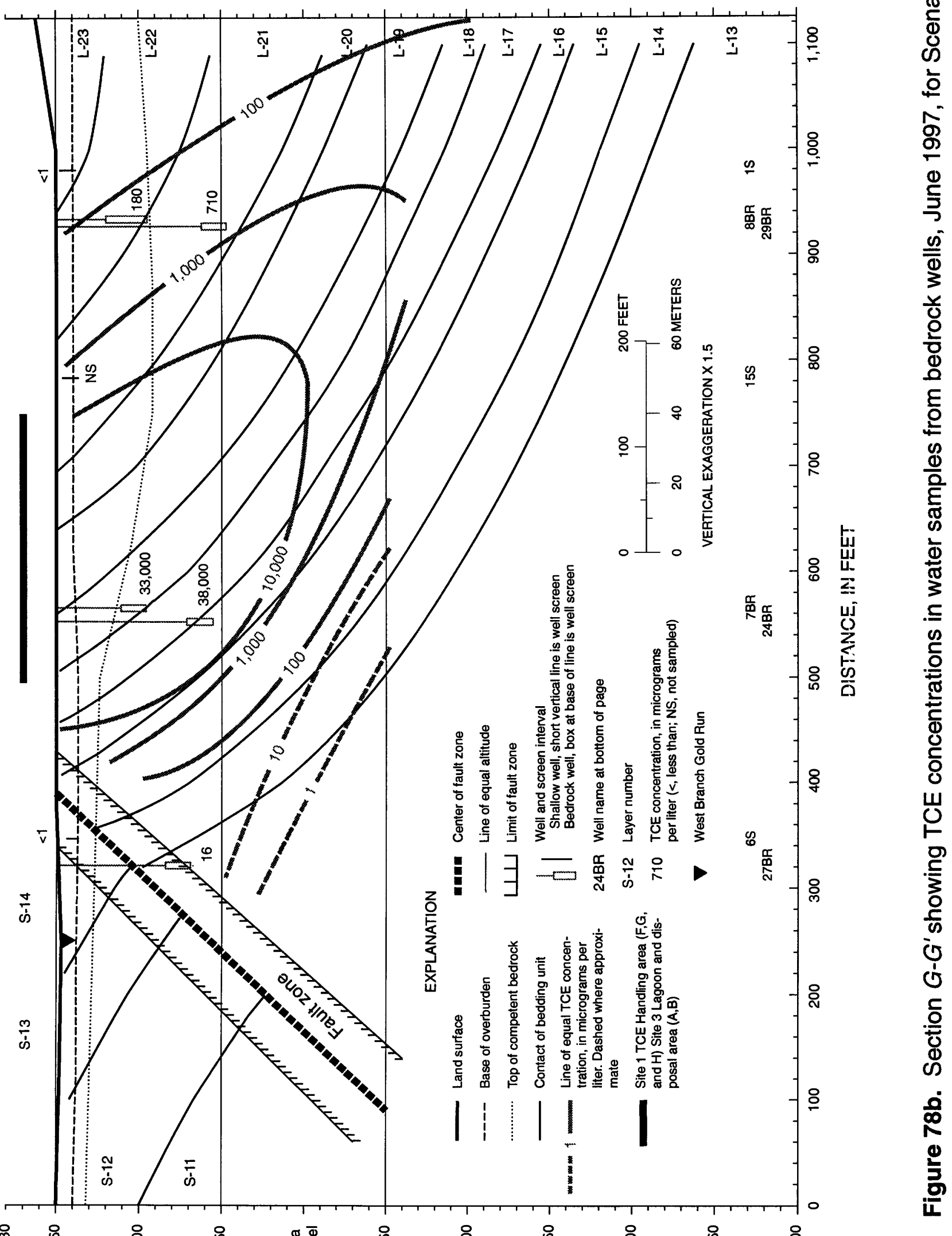


I

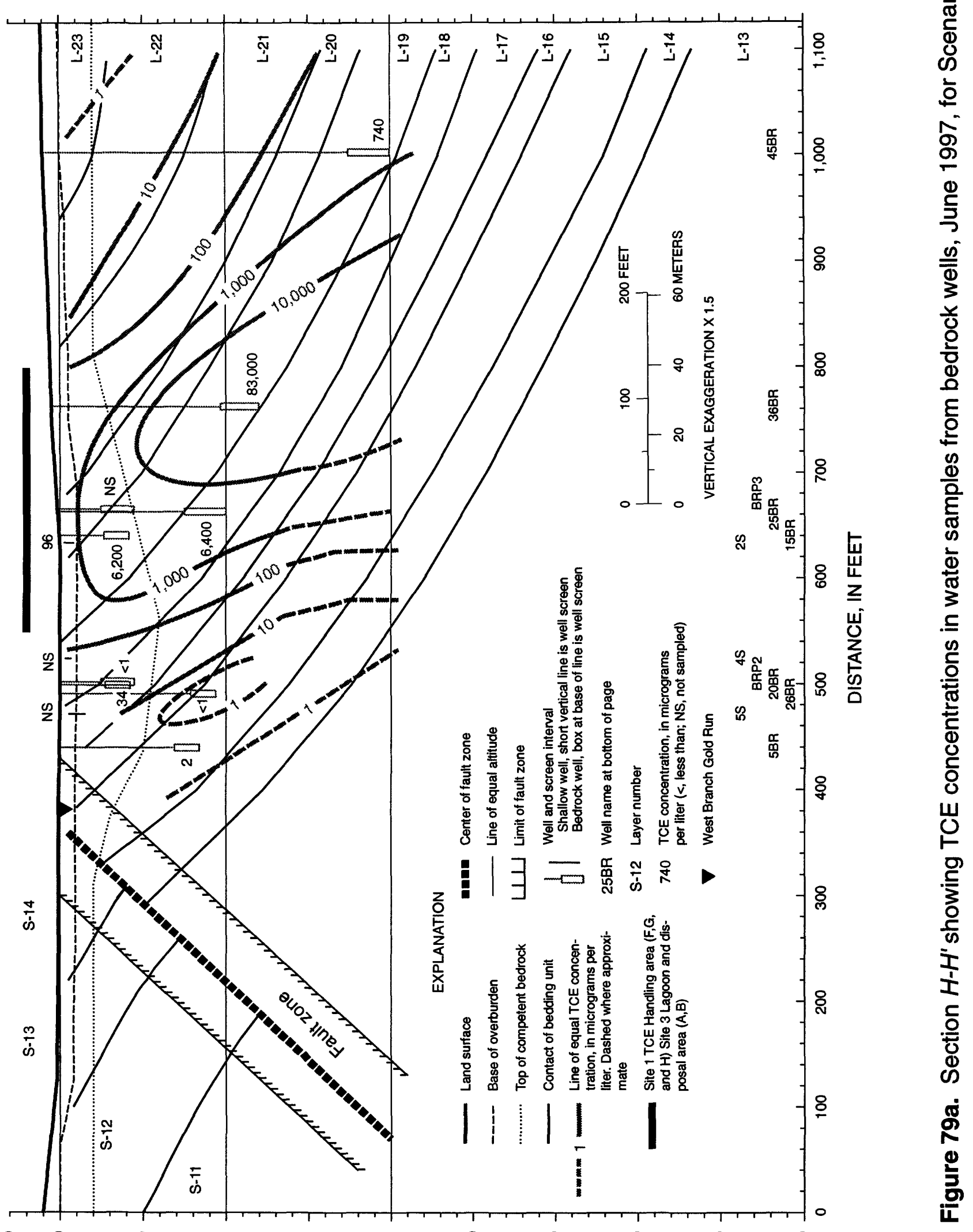


i

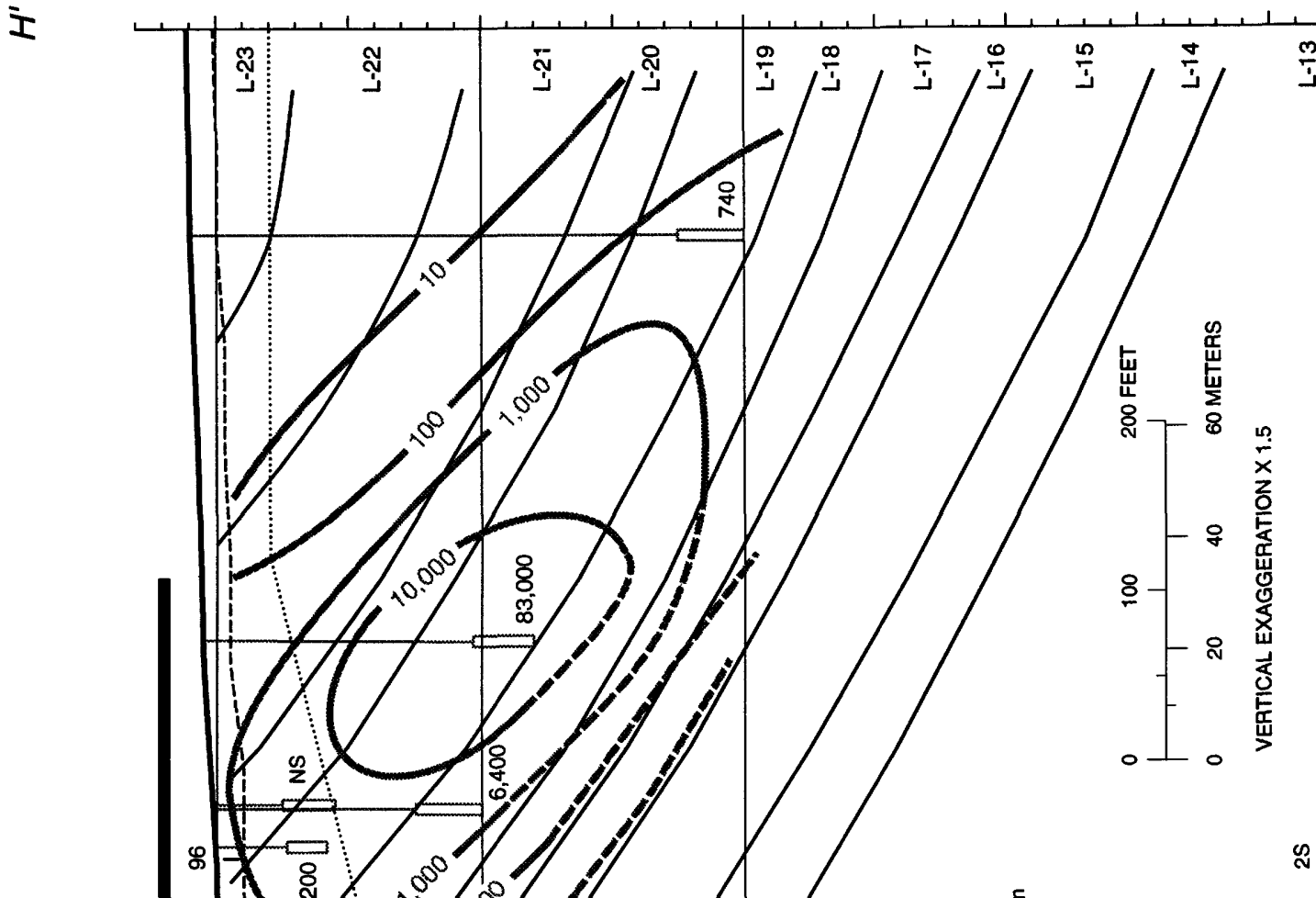

은

$-18$

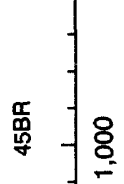

흔

ลิ

$\stackrel{\Phi}{丂}$

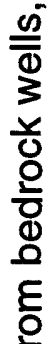

$-8$

8

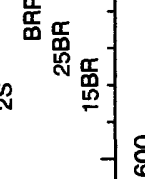

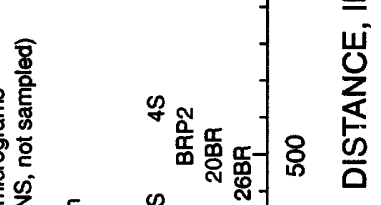

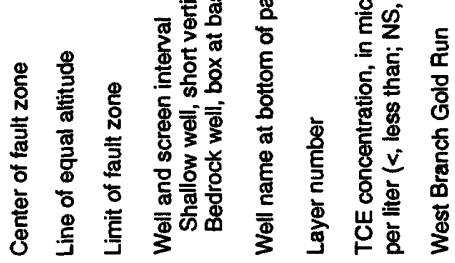

㩊

8

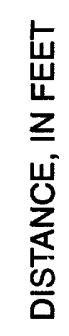

音

.$\subseteq$

$I$
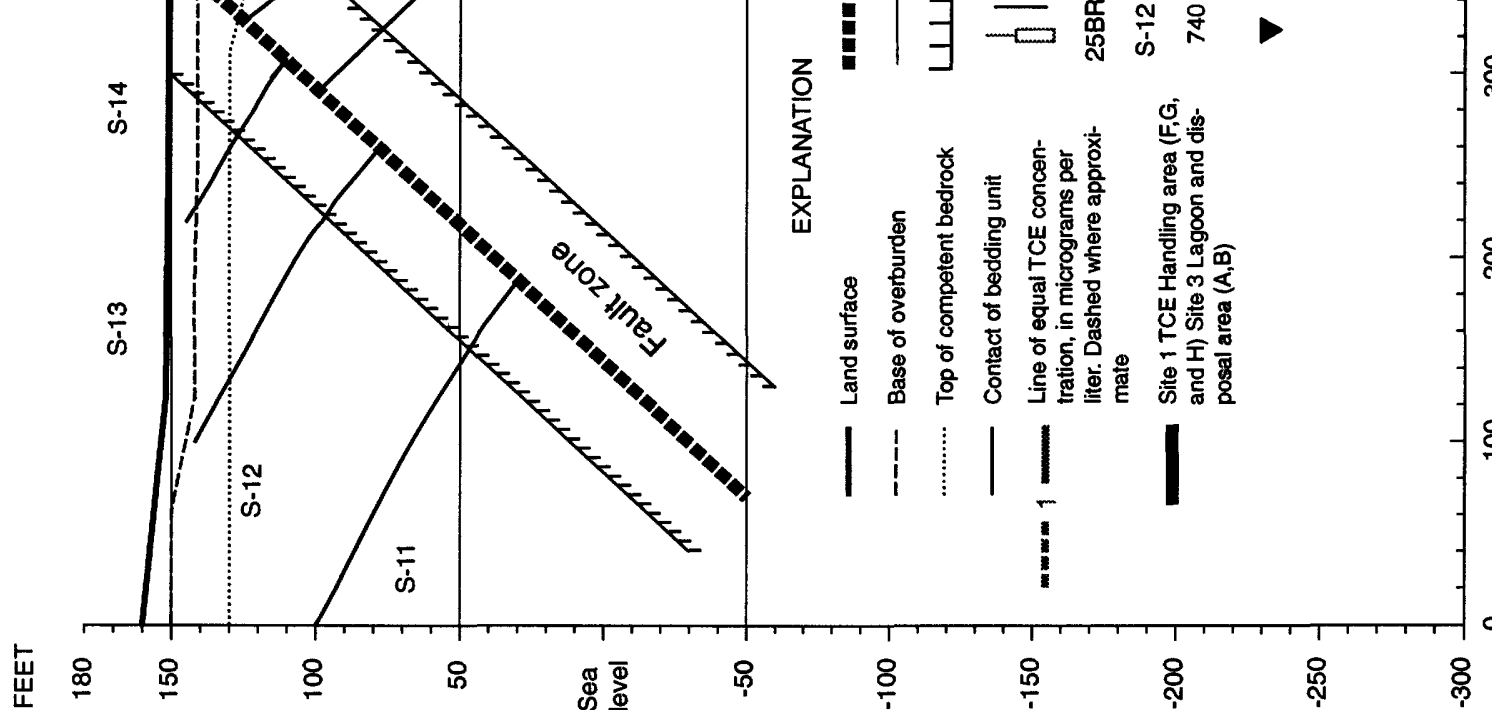

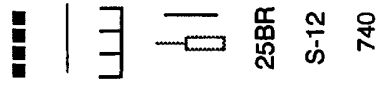

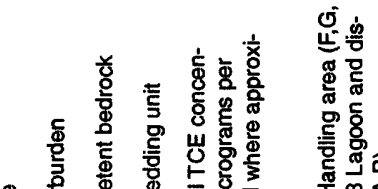

8 है क्षे

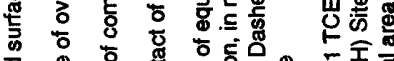

惫惫高

$11: 1$
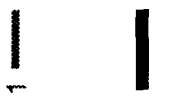

命 


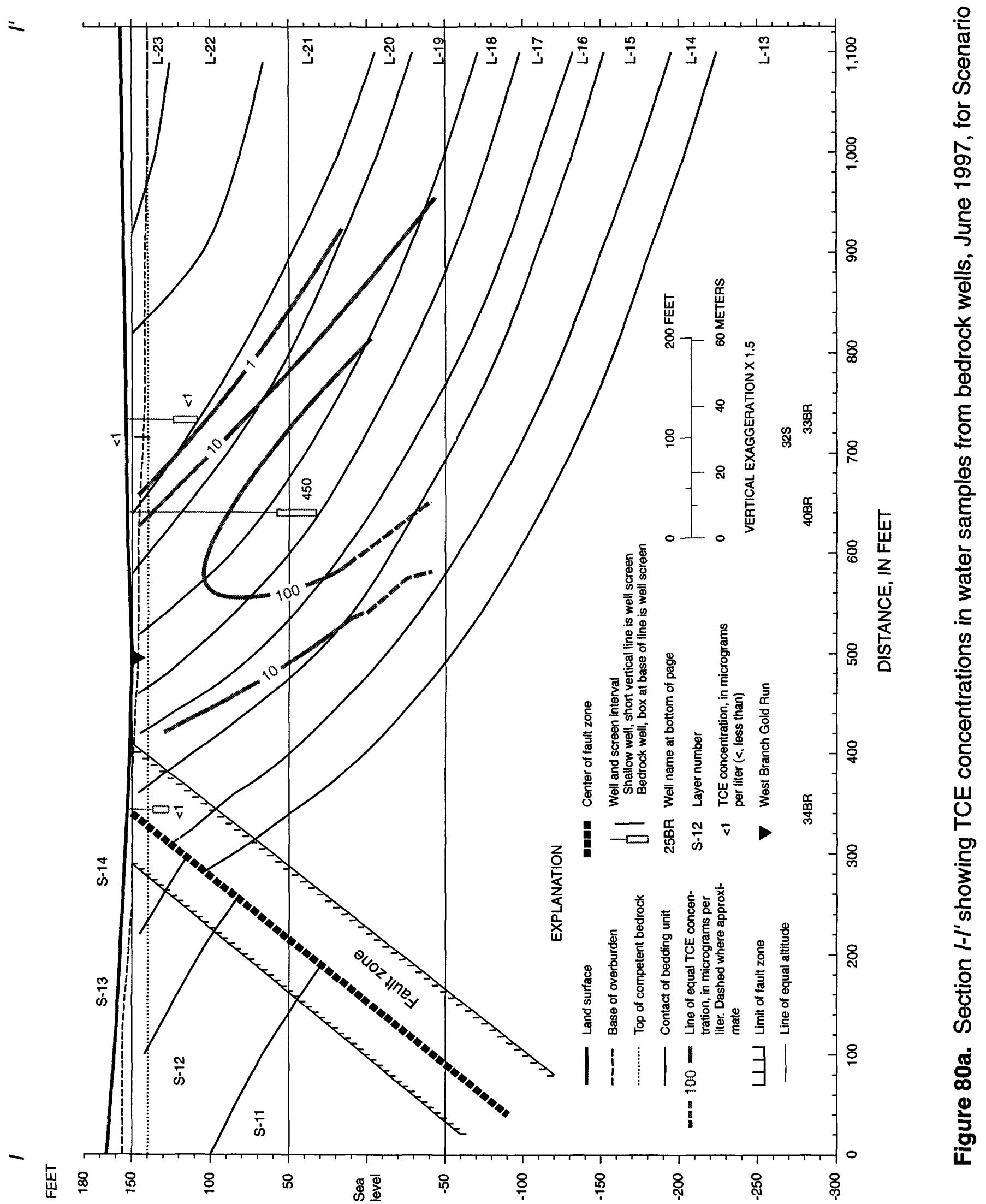




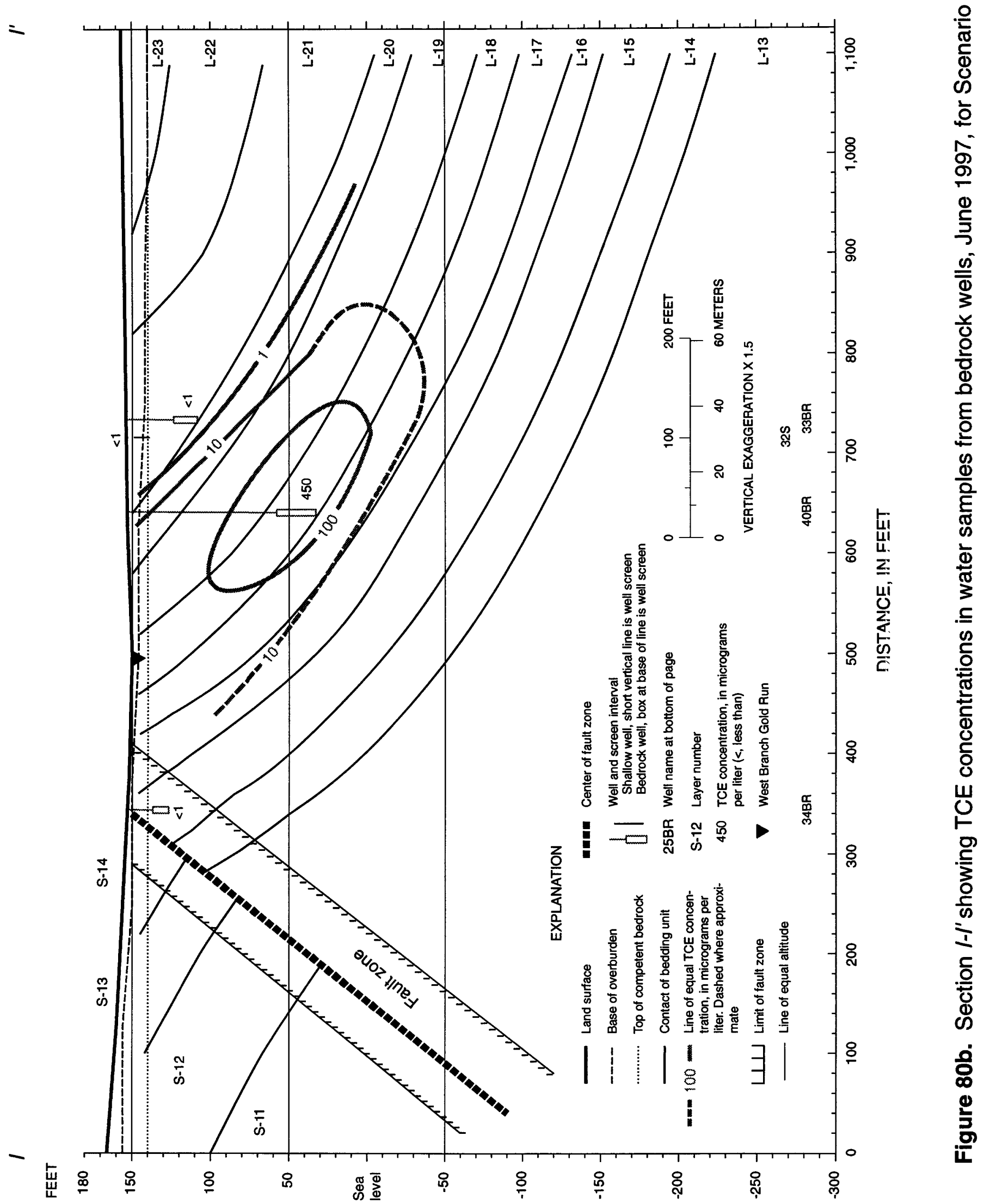


extensive zone around the NAWC where sediments and ground water show background concentrations of TCE that range from 1 to 10 $\mu \mathrm{g} / \mathrm{L}$. In selected areas away from Site 1 , Site 3 , and building 21 , TCE may be present in ground water as a result of an isolated spill or other single event.

TCE contamination in the aquifer can be in two forms: pure TCE, also known as dense non-aqueous phase liquid (DNAPL) TCE, and dissolved TCE, which is TCE in solution in ground water. In this report, the two phases of TCE will be referred to as DNAPL TCE and dissolved TCE.

DNAPL TCE was never recovered in water samples from monitoring wells at NAWC. The principle mechanism for conversion of DNAPL TCE to dissolved TCE is dissolution in ground water. Dissolved TCE was recovered in water samples from 36 of the 48 bedrock wells that were sampled during June 1997 in the study area. At most wells, the concentration of dissolved TCE has decreased over time. The decrease is a result of biodegradation, abiotic degradation, dispersion, adsorption, dilution, and evaporation. Collectively, actions that decrease the concentration of TCE in ground water are referred to as natural attenuation.

There are two possible scenarios for DNAPL TCE contamination in the Site 1 area. The first scenario is that DNAPL TCE sank into the aquifer to depths greater than $250 \mathrm{ft}$ below land surface and is currently at those depths. The second scenario is that DNAPL TCE sank into the aquifer but dissolved and degraded when it reached a depth of $100 \mathrm{ft}$ below land surface. In scenario 2, no DNAPL TCE is present at depths greater than $100 \mathrm{ft}$. It is uncertain which scenario is correct in the Site 1 area; therefore, both scenarios are discussed in detail. In the Site 3 area, only dissolved TCE was deposited at land surface; therefore, there can be no DNAPL TCE at depth.

\section{Site 3: Lagoon and Sludge Disposal Area}

Prior to the mid-1980's, dissolved T $2 E$ was deposited into the Site 3 lagoon (fig. 69), where it evaporated or infiltrated to the w'ater table. During June 1997, 11 bedrock wel's shown on sections $A, B$, and $C$ were sampled for TCE (figs. 72, 73, and 74). Well 2BR had a TCE concentration of $130 \mu \mathrm{g} / \mathrm{L}$ in 1997 , whereas during 1992-93, the TCE concentration was 320,230 , and $110 \mu \mathrm{g} / \mathrm{L}$. Well $11 \mathrm{BR}$ had a TCE concentration of $7 \mu \mathrm{g} / \mathrm{L}$ in 1977 , but had TCE concentrations of $<1$ to $16 \mu \mathrm{g} / \mathrm{L}$ during 1992-93. These data indicate that the TCE concentration is decreasing with time in the Site 3 area. The TCE concentration in well 51BR was $62 \mu \mathrm{g} / \mathrm{L}$, but it was sampled only during June 1997. Well 31BR was sampled in 1993 and 1997 with a concentration of 23 and $51 \mu \mathrm{g} / \mathrm{L}$, respectively. It is unclear why TCE concentrations increased in well $31 \mathrm{BR}$. W'ell 14BR shows undetected levels of TCE, and well 48BR was sampled only once with $\varepsilon$. TCE concentration of $11 \mu \mathrm{g} / \mathrm{L}$ in 1997.

Ground-water flow in the Site 3 area is along strike and to the west-southwest. $\mathrm{T}^{\mathrm{T}} \cdot \mathrm{e}$ shape of the TCE plume and the decrease in TCE concentrations downgradient indicates that the plume is moving from the lagoon source area along the north side of the fault towards the west-southwest along with th? ground water. The lagoon and the sludge disposal area may straddle the fault. It is possible that some dissolved TCE may have flowed to the south side of the fault. TCE concentrations of $7 \mu \mathrm{g} / \mathrm{L}$ in well 50BR and 3 $\mu \mathrm{g} / \mathrm{L}$ in well 37BR may be associated with contamination from the Site 3 area.

During the early 1990 's, the sludge disposal area was excavated and deemed remediated by the N.J. Department of Envirormental Protection. Therefore, it is no lon?er considered to be a source of TCE contamination. (Donna Gaffigan, N.J. Department of Environmental Protection, oral commun. 1997). 


\section{Area Between Site 3 and Site 1}

Sections D and E cross the area between Sites 3 and 1. TCE was reportedly used for metal-cleaning purposes in building 21 , and site construction plans show a buried TCE storage tank west of the building 21 (fig. 69). Concentrations of TCE were $7 \mu \mathrm{g} / \mathrm{L}$ in well 49BR and $450 \mu \mathrm{g} / \mathrm{L}$ in well 42BR, but those wells were sampled only once. Concentrations of TCE were $34 \mu \mathrm{g} / \mathrm{L}$ in water samples from well 16BR and are much lower than the 190, 250 and $87 \mu \mathrm{g} / \mathrm{L}$ reported during 1992-93 (International Technology Corporation, (July 1994, table 4-1 A and 4-1B). The relatively low TCE concentrations in wells 49BR, 16BR, and 42BR may indicate that the wells are on the eastern flank of the Site 1 contamination plume, or it may reflect contamination as a result of metal cleaning in building 21 and possible underground storage of TCE.

TCE was undetected in wells 6BR, 13BR, 39BR, and 42BR in 1997. TCE was not detected in 1993 in wells 6BR and 13BR (International Technology Corporation, (July 1994, table 4-1 A and 4-1B). Wells 39BR and 42BR were sampled only once.

\section{Site 1: Brine-Handling Area}

DNAPL TCE spilled or leaked onto the ground and dissolved TCE flowed into ditches at Site 1. The TCE infiltrated downward to below the water table resulting in DNAPL and dissolved TCE contamination. To evaluate the extent of possible DNAPL and dissolved TCE at Site 1, water samples from bedrock monitoring wells were collected and analyzed during June 1997. Concentrations of TCE are plotted in map view (figs. 69 to 71) and in section view (figs. 77 to 79 ) for the two scenarios.

Scenario 1 assumes that DNAPL TCE exists from land surface to a depth greater than $200 \mathrm{ft}$ below land surface. Scenario 2 assumes that DNAPL TCE does not exist at depths greater than $100 \mathrm{ft}$ below land surface. For both scenarios, the map view for TCE cor entrations at land surface (fig. 69) and at $100 \mathrm{ft}$ below land surface (fig. 70) are essentially identical. However, the interpretation of TCE concentrations at a depth of $200 \mathrm{ft}$ below land surface for scenario 1 (fig. 71a) is significantly higher than the interpretation for scenario 2 (fig. 71b). Correspondingly, the interpretation for the section view $F, G$, and $H$ for Scenario 1 (figs. 77a, 78a, and 79a) and Scenario 2 ( $\mathrm{r} ; \mathrm{s}$. $77 \mathrm{~b}, 78 \mathrm{~b}$, and $79 \mathrm{~b}$ ) are nearly identical to a depth of $100 \mathrm{ft}$ below land surface but are significantly higher at depths greater than 100 $\mathrm{ft}$ below land surface. Figures 77a, 78a, and 79a show open contours at depths greater that $100 \mathrm{ft}$ below land surface and potential DNAPL TCE in a zone between the 10,0 ? ? $\mu \mathrm{g} / \mathrm{L}$ contours at depth greater than $200 \mathrm{ft}$ below land surface.

\section{Scenario 1: DNAPL TCE at depths greater than 250 feet}

DNAPL TCE from land surface sank into the bedrock aquifer below Site 1 and moved downward driven by gravity and density differences. The DNAPL TCE flowpaths 'vere in the more permeable shallow-dipping waterbearing zones and near vertical partings. In the water-bearing zones, the DNAPL TCE flowed in the downdip direction of $\mathrm{N}^{\circ} \mathrm{W}$. In ple ces where the DNAPL TCE intercepted a vertical parting, it would flow vertically downwart. Thus, the DNAPL TCE would ultimately flow downward and northwestward. The only thing that would stop the flow of DNAPL TCE was the closure of fractures with depth. Most fractures are closed at a depth of $500 \mathrm{ft}$ below land surface, and more likely, most are clcred by $300 \mathrm{ft}$ below land surface.

DNAPL TCE flow direction was essentially unaffected by the regional hydraulic gradient and the ground-water-flow direction. The result of Scenario 1 is a plume that contains significant amounts of DNAPL T $\mathrm{TE}$ 
at a depth of 200 to $300 \mathrm{ft}$ below land surface in bedding units L-15 to L-19 and about $100 \mathrm{ft}$ north of the Site 1 surficial source area. The DNAPL TCE plume in Scenario 1 exists inside the $10,000-\mu \mathrm{g} / \mathrm{L}$ contour lines (figs. 71a and 77a, 78a, and 79a).

As stated earlier, DNAPL TCE has not been found in any well at the NAWC. The saturation limit of TCE in water is $1,100,000$ $\mu \mathrm{g} / \mathrm{L}$. Results of laboratory and field tests at other contamination sites have shown that ground-water samples that contain TCE concentrations in excess of $22,000 \mu \mathrm{g} / \mathrm{L}$, which is 2 percent of the saturation limit, may indicate that DNAPL TCE is near the sampling site (Chappell, 1993). Based on these data, the following five wells may have DNAPL TCE near the screen interval: wells 30BR and 38BR, Section F (fig. 77a); wells 7BR and 24BR, Section G (fig. 78a); and well 36BR, Section H (fig. 79a). Collectively, these wells are screened in bedding units L-16 to L-19. Presently, there are no wells with screens directly below the wells 30BR, 38BR, 24BR, and 36BR and in bedding units L-15 to L-17. In summary, it is interpreted that DNAPL TCE may be present in fractures and partings below these wells.

Dissolved TCE was detected in 21 of 23 bedrock wells that were sampled north of the fault along sections $\mathrm{F}, \mathrm{G}$, and $\mathrm{H}$ (figs. 77a, 78a, and 79a). TCE concentrations in these 21 bedrock wells ranged from 18 to $83,000 \mu \mathrm{g} / \mathrm{L}$. TCE was detected in one of three bedrock wells south of the fault in the Site 1 area.

Wells 45BR and 46BR were installed in 1997 to determine how far north the dissolved TCE plume moved in bedding units L-18 and L-19. TCE concentrations in wells 45BR and 46BR were 960 and $1,000 \mu \mathrm{g} / \mathrm{L}$ respectively in 1997. These concentrations indicate that dissolved TCE has moved north of wells 45BR and 46BR in bedding units L-18 and L-19 and also indicate that DNAPL TCE has not moved north of these wells. Drilling additional wells into bedding units L-16 to L-19 north of well 45BR and 46BR may be considered if it is decided to map the precise location of the northern limit of the dissolved TCE plume.

Wells 40BR and 45BR were installed to determine how far west the dissolved TCE plume moved in bedding units L-18 and L-19. Concentrations in wells 40BR and 45BP were 450 and $910 \mu \mathrm{g} / \mathrm{L}$, respectively in 1997 . These values indicate that dissolved TCE but $r$ it DNAPL TCE has moved west of these wells in these bedding units. Drilling additional wells into bedding units L-16 to L-19 west of wells 40BR and 45BR may be considered to determine the concentration of TCE and the effect of ground-water levels near the headwaters of the West Branch of Gold Run.

The southern extent of the TCE plume is limited by the fault. A TCE concentration of $31 \mu \mathrm{g} / \mathrm{L}$ measured in a water sample from well 22BR is the only site with TCE on the south side of the fault in the Site 1 area. The TCE concentrations from well 22BR were 18 to 85 $\mu \mathrm{g} / \mathrm{L}$ during 12 sampling events in 199: and 10 to $16 \mu \mathrm{g} / \mathrm{L}$ during 4 sampling events in 1992-93. Well 22BR is within $20 \mathrm{ft}$ west of a storm sewer outfall box. It is plausible that TCE contamination in this well is related to the TCE contamination in or around the sto'm sewer line. Wells 28BR and 35BR, also south of the fault in the Site 1 area, have prod iced water with undetected levels of TCE. Well 28BR was sampled twice in 1995 and showed undetected and $12 \mu \mathrm{g} / \mathrm{L}$ TCE concentrations. Well 35BR was sampled 12 times during 1995 and showed undetected TCE concentrat ins during 8 sampling events, estimated 2 to $3 \mu \mathrm{g} / \mathrm{L}$ during 3 sampling events, and $45 \mu \mathrm{g} / \mathrm{L}$ during 1 sampling event. It is interprete $t$ that the concentration of $45 \mu \mathrm{g} / \mathrm{L}$ is a result c $f^{f}$ cross contamination while sampling the well.

Wells 41BR, 42BR, and 39BR were drilled in 1997 to determine the eastern extent of the TCE plume in bedding units L-19 and L13 to L-14. TCE concentration in well $41 \mathrm{BR}$ 
was $450 \mu \mathrm{g} / \mathrm{L}$, and TCE was undetected in the other two wells. Water-quality data from well 41BR indicate that dissolved TCE has moved either from Site 1 in an eastward direction within bedding unit L-19 to this site or more likely from building 21 northward and downward in bedding unit L-19. Drilling additional wells into bedding units L-16 to L-19 east of well 41BR may be considered to further delineate the extent of the plume but that may not be possible because of existing buildings and service lines.

\section{Scenario 2: No DNAPL TCE at depths greater than 100 feet}

DNAPL TCE from land surface sank in to the bedrock aquifer below Site 1 and moved downward and northward much like that described in Scenario 1. The DNAPL TCE degraded, dissolved, adsorbed, and dispersed in the uppermost $100 \mathrm{ft}$ of overburden and bedrock. As a result of this scenario DNAPL TCE did not move into the deeper part of the bedrock aquifer. The configuration of the contour lines at land surface and 100 feet below land surface are identical for Scenarios 1 and 2 (figs. 69 and 70). At a depth of $200 \mathrm{ft}$ below land surface, the contour lines for Scenario 2 (fig. 71b) are much lower values than for Scenario 1. Sections F, G, and H show closed contours for depths greater than $100 \mathrm{ft}$ below land surface for scenario 2 (figs. 77b, $78 \mathrm{~b}$, and $79 \mathrm{~b}$ ), whereas the sections show open contours for scenario 1 (figs. 77a, 78a, and 79a). Scenario 2 indicates that the maximum concentrations of TCE are located in the uppermost $100 \mathrm{ft}$ of the bedding units L-16 to L-19.

\section{Area West of Site 1}

TCE concentrations in bedrock wells along section I west of Site 1 range from undetected to $450 \mu \mathrm{g} / \mathrm{L}$. Ground-water-flow direction at the Site 1 area is westward. Dissolved TCE may have moved with the ground-water flow, and therefore, TCE concentrations may be high in bedding units L15 to L-19 as shown along section I. However, the TCE concentration may have declined significantly as a result of natural attenuation and is at very low or undetected concentrations west of Site 1 contamination plume.

\section{cis-1,2-Dichloroethylene (cis-DCE)}

The U.S. Navy did not use cis-DCE as part of the routine operation at the NAWC. Therefore, in all likelihood, all cis-DCE in the aquifer results from biodegradation of dissolved TCE in reducing environments and abiotic degradation of dissolved TCE in oxidizing environments. cis-DCE concentrations are shown in maps and sections (figs. 81 to 92). Thirty-one of the 48 bedrock wells sampled during June 1997 show cis-DCE concentration above the detection limit of 1 $\mu \mathrm{g} / \mathrm{L}$. Five bedrock wells show cis-DCE concentrations that range from 11,000 to $52,000 \mu \mathrm{g} / \mathrm{L}, 4$ wells show cis-DCE concentrations that range from 1,900 to $7,200 \mu \mathrm{g} / \mathrm{L}, 6$ wells show cis-DCE concentrations that range from 120 to $800 \mu \mathrm{g} / \mathrm{L}, 16$ wells show concentrations that range from 1 to $99 \mu \mathrm{g} / \mathrm{L}$, and 17 wells show no detectable cis-DCE.

\section{Site 3: Lagoon and Sludge Disposal Area}

Water samples from bedrock wells in the Site 3 area showed cis-DCE concentrations that range from undetected to $33 \mu \mathrm{g} / \mathrm{L}$ during 1997. The higher concentrations were directly under the lagoon and the former sludge disposal area. Well 11BR showed cis-DCE concentrations of $26 \mu \mathrm{g} / \mathrm{L}$ (fig. 85), and wells 2BR and 51BR showed concentrations of 33 and $29 \mu \mathrm{g} / \mathrm{L}$, respectively (fig. 84). Concentrations in well 11BR were 120 to $15 \mu \mathrm{g} / \mathrm{L}$ during $1992-93$ and 16 to $26 \mu \mathrm{g} / \mathrm{L}$ in 1995 . Concentrations in well $2 \mathrm{BR}$ were 18 to $45 \mu \mathrm{g} / \mathrm{L}$ in 1993. Well 5BR was sampled only once. Because ground-water flow in the Site 3 area is 

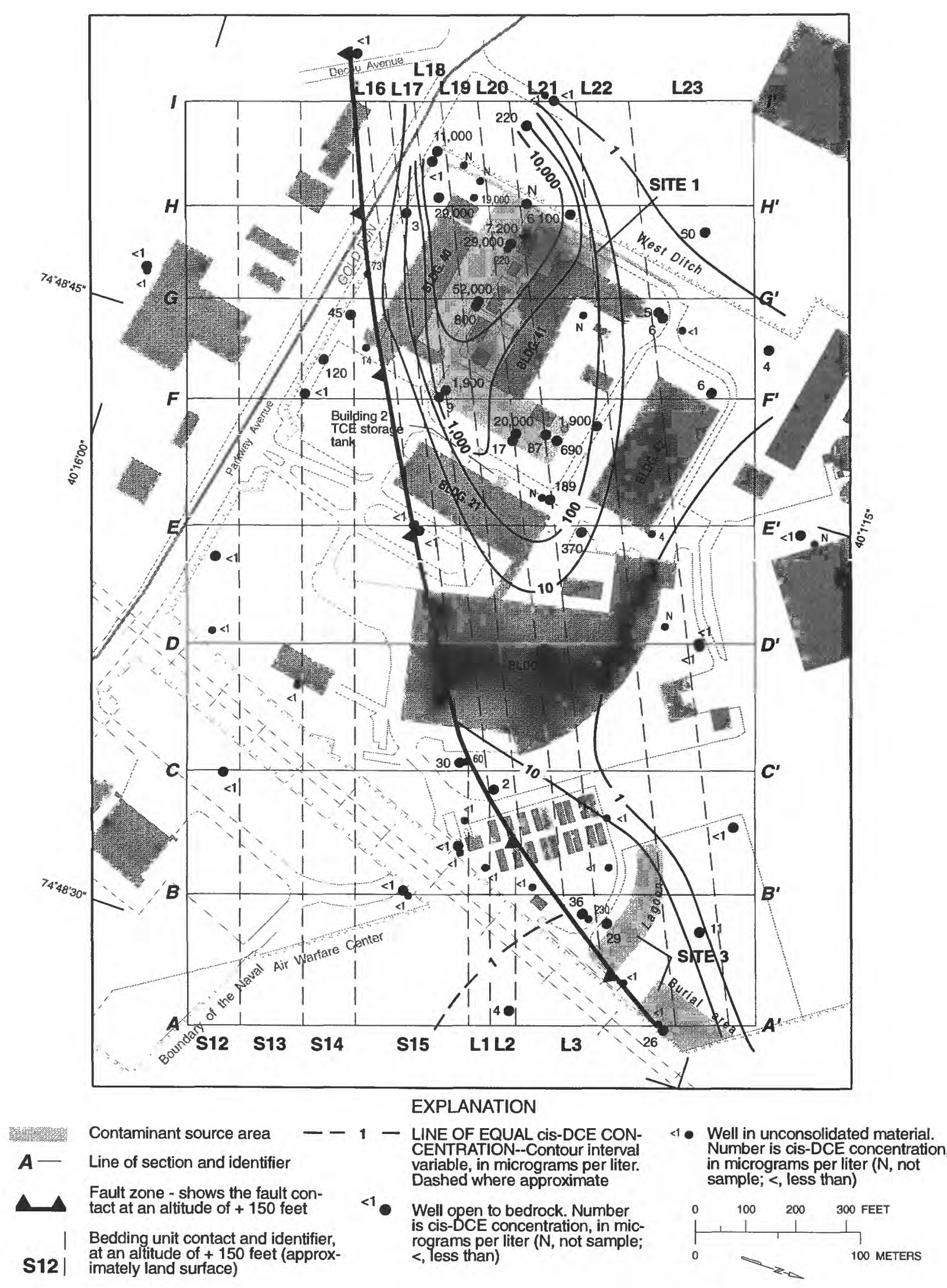

Figure 81. cis-DCE concentrations, in micrograms per liter, in water samples from bedrock and shallow wells, June 1997, and contours for top of bedrock (an altitude of +150 feet and approximately land surface), Naval Air Warfare Center, West Trenton, N.J. 


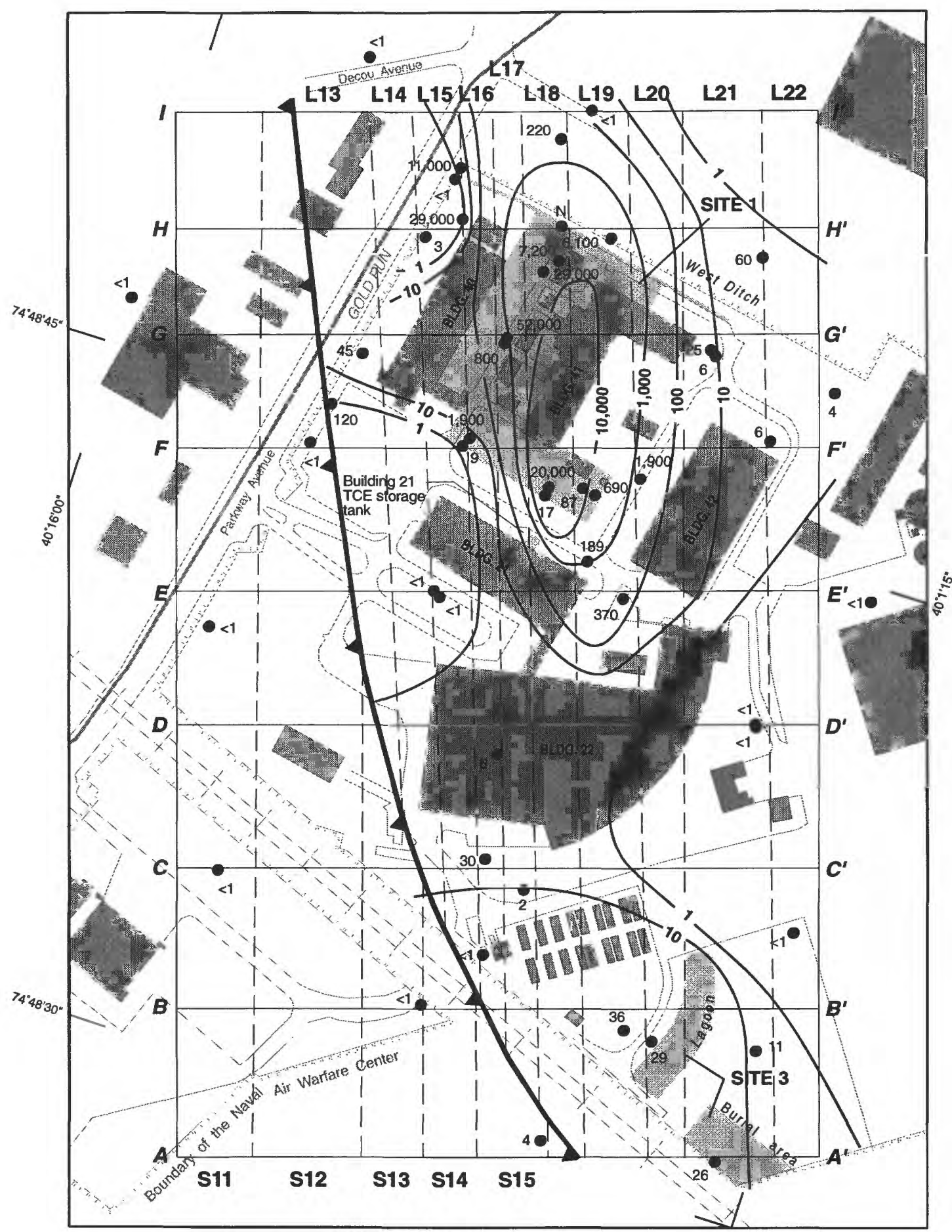

EXPLANATION

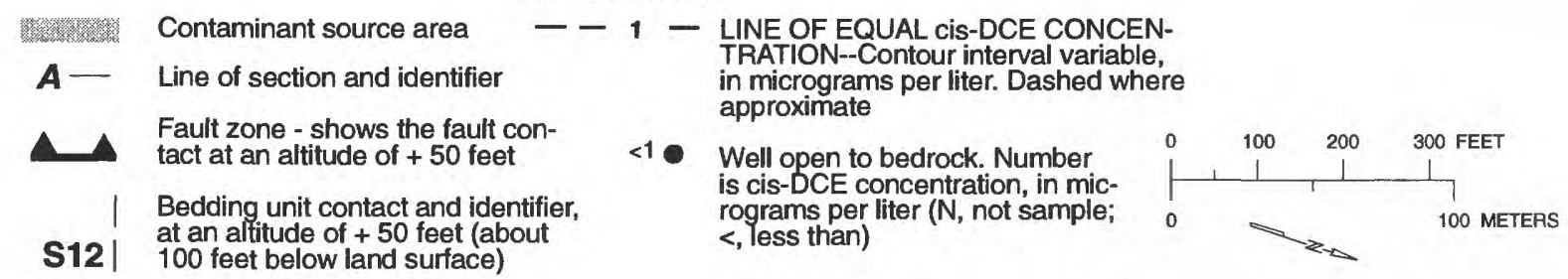

Figure 82. cis-DCE concentrations, in micrograms per liter, in water samples from bedrock, June 1997, and contours for an altitude of +50 feet (about 100 feet below land surface), Naval Air Warfare Center, West Trenton, N.J. 


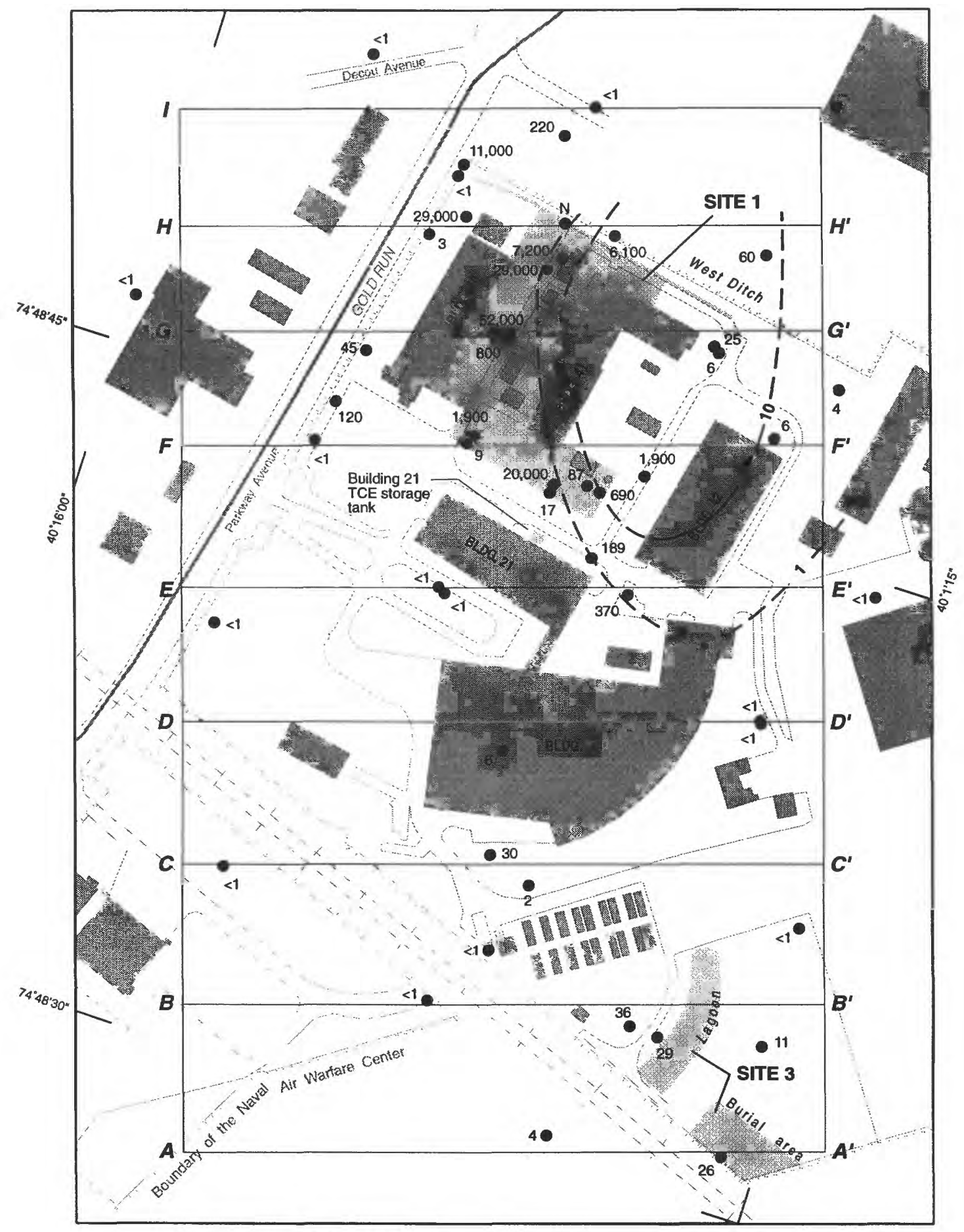

EXPLANATION

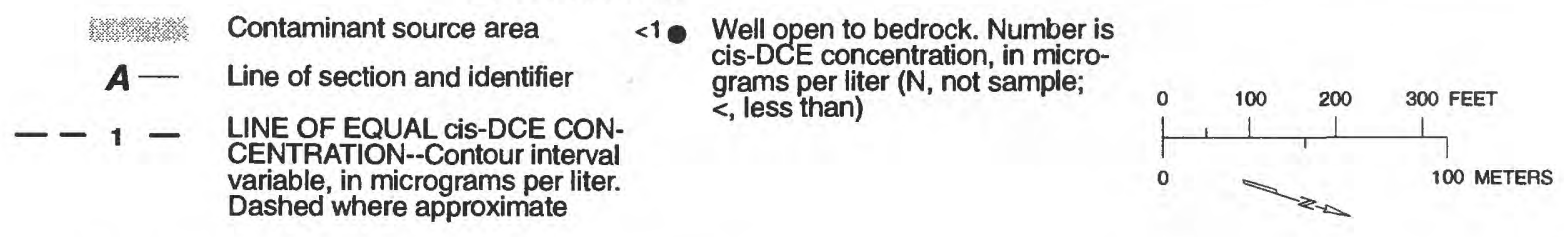

Figure 83. cis-DCE concentrations, in micrograms per liter, in water samples from bedrock wells, June 1997, and contours for an altitude of - 50 feet (about 200 feet below land surface), Naval Air Warfare Center, West Trenton, N.J. 
广

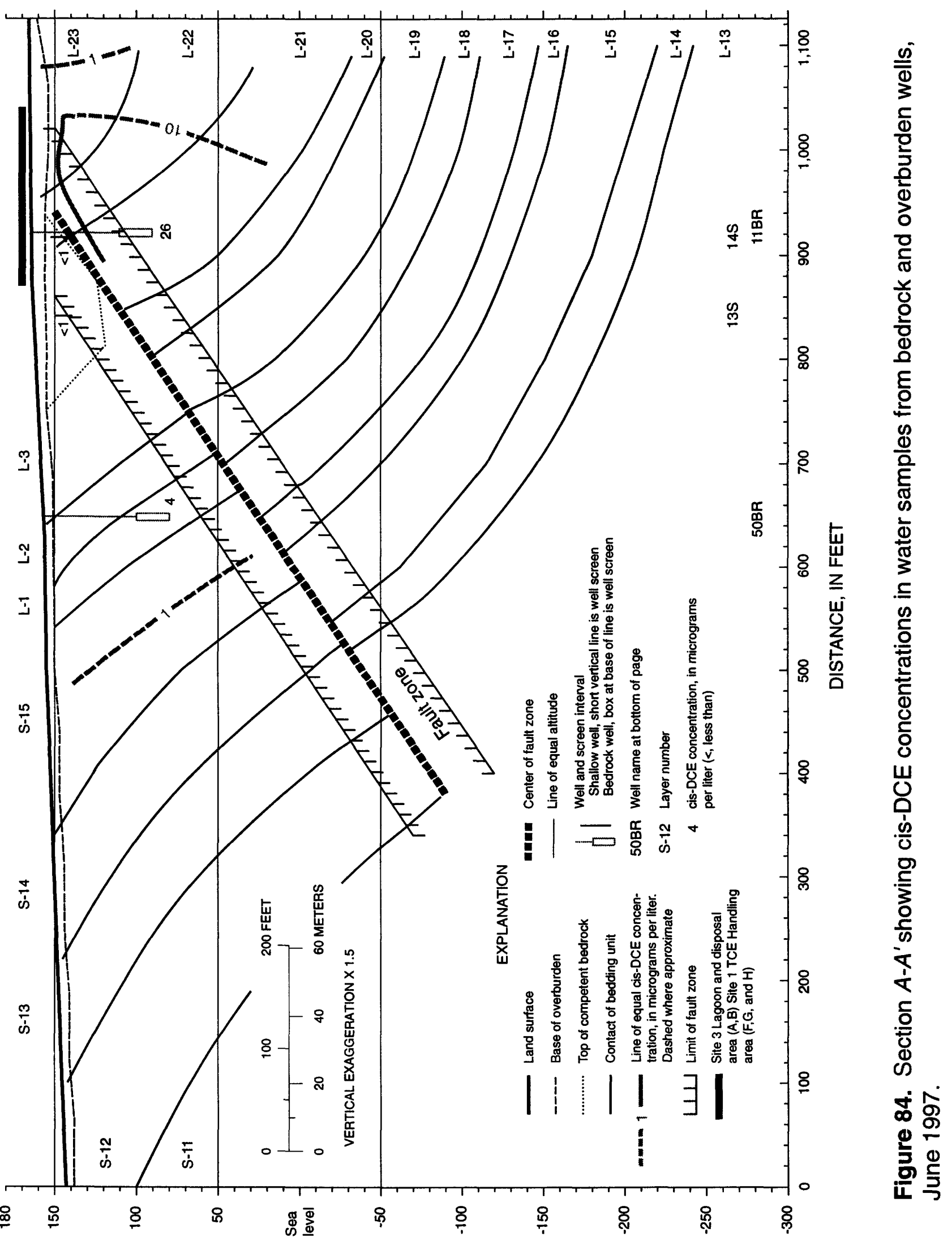


in

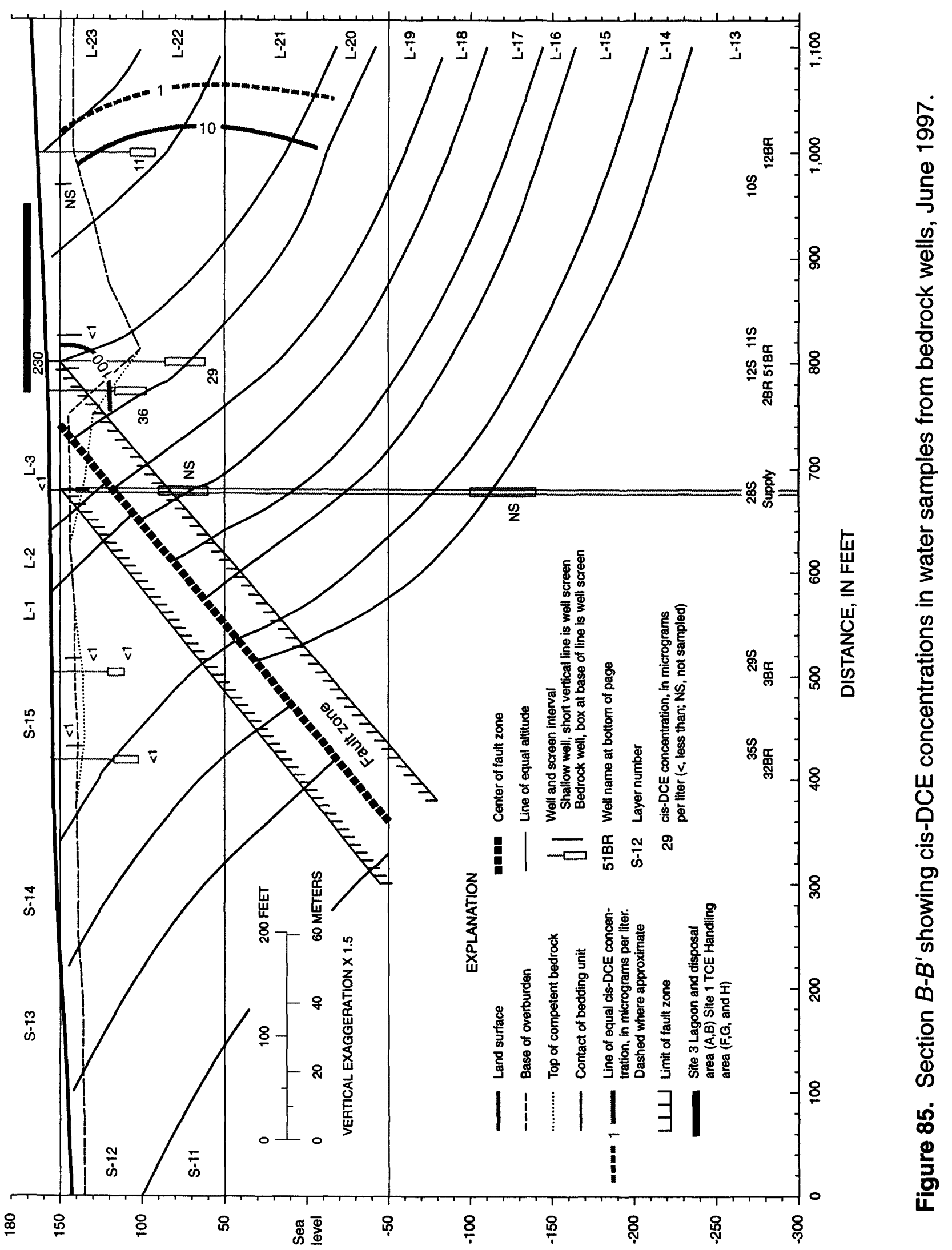




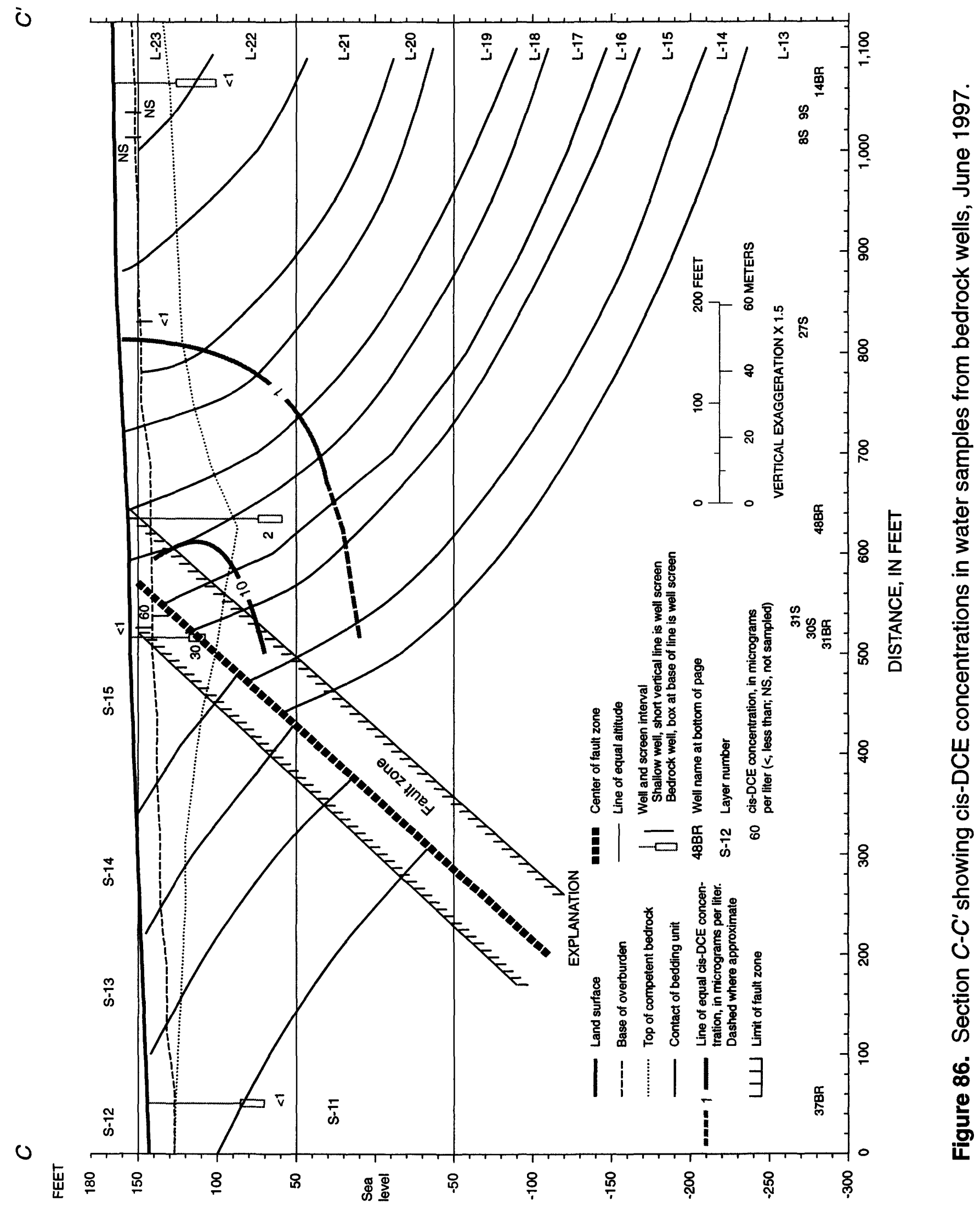




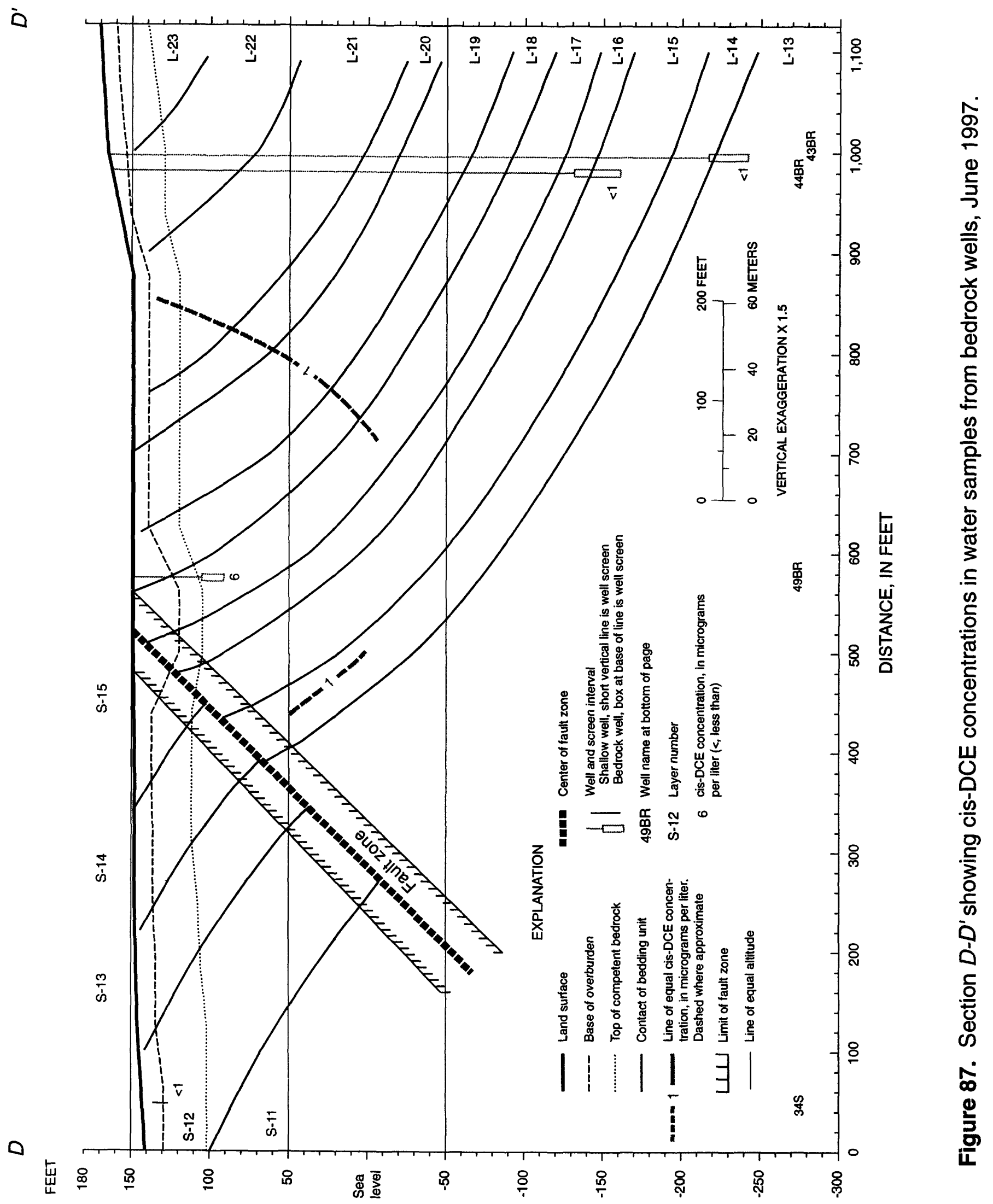


u

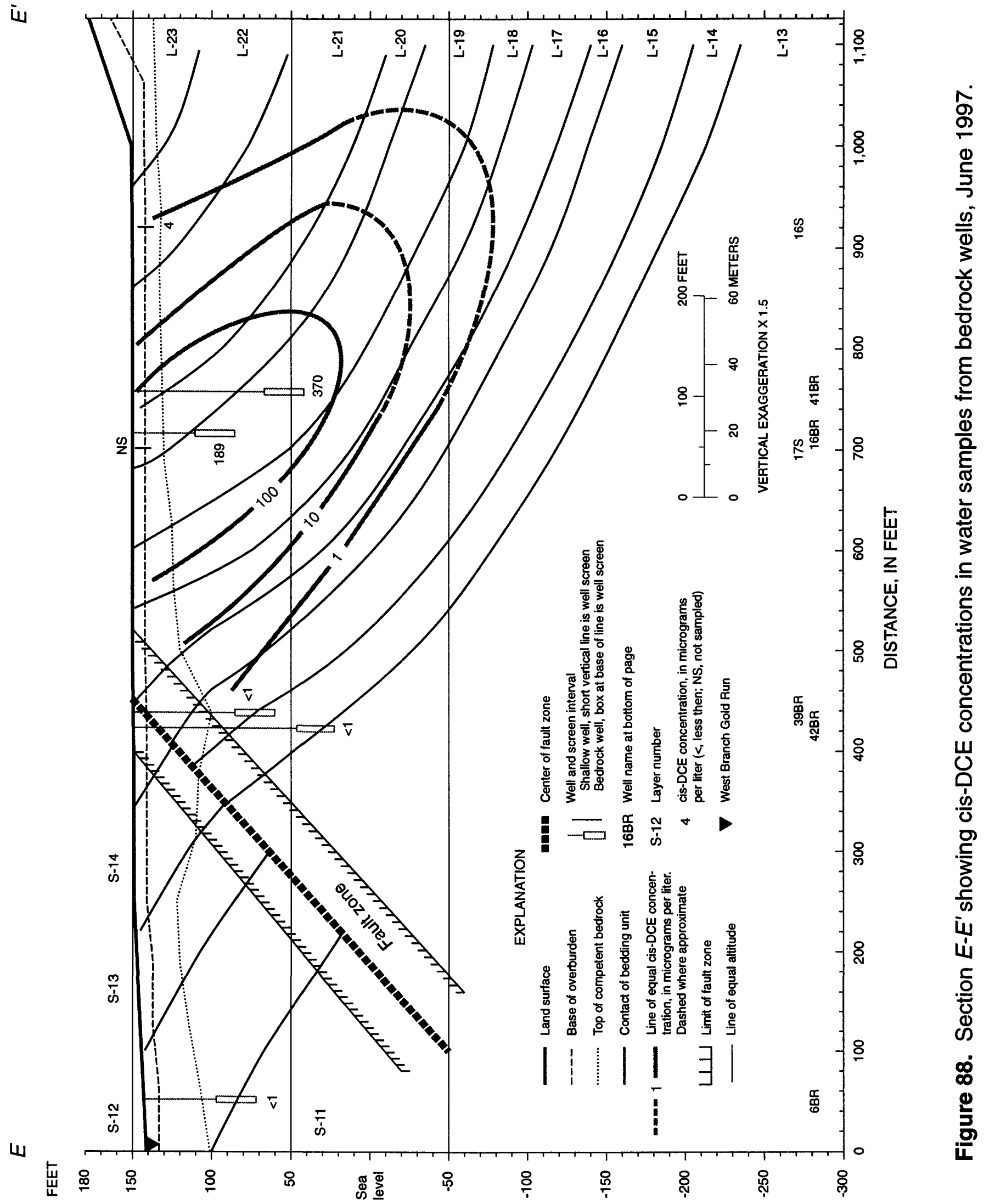




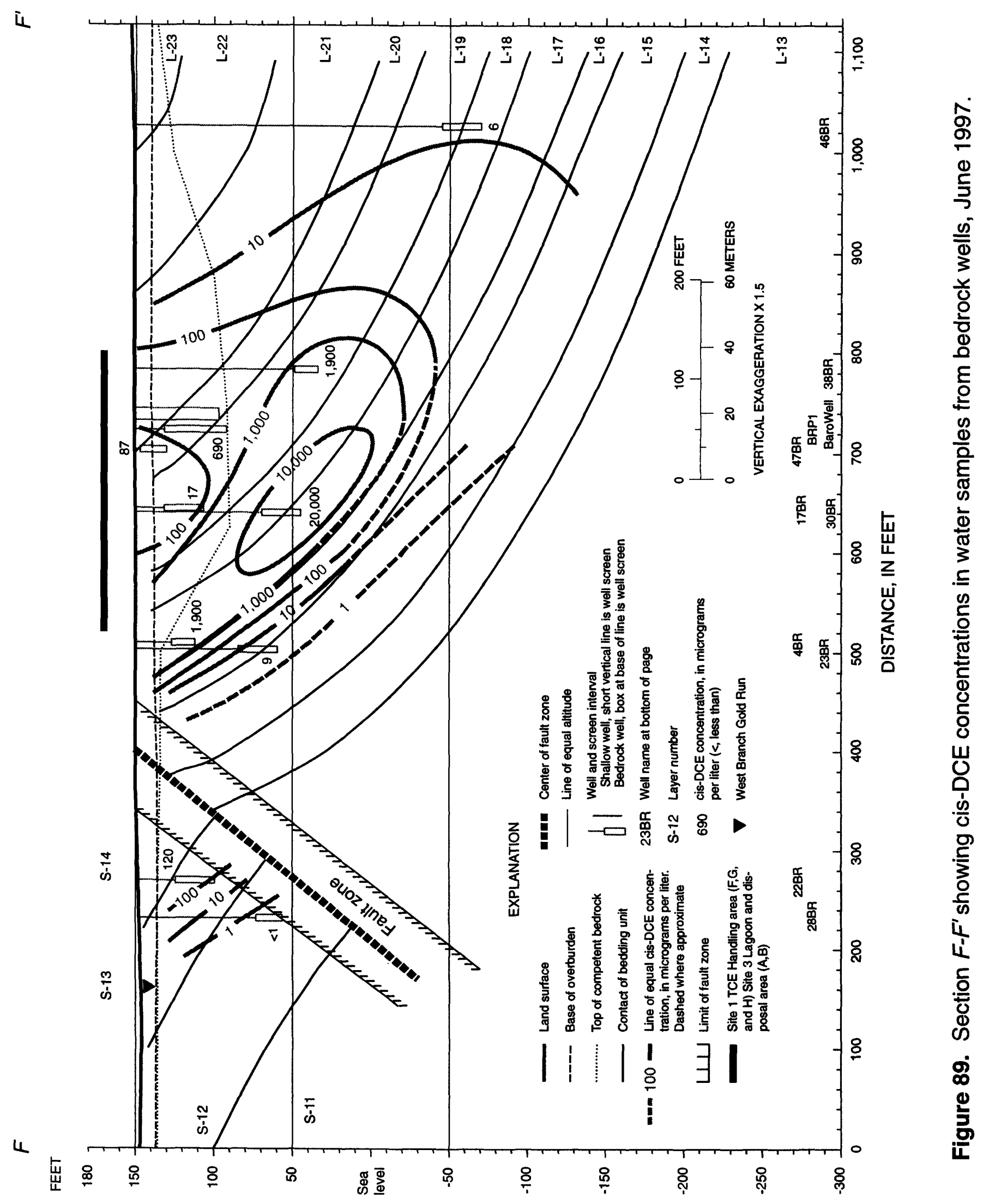


i

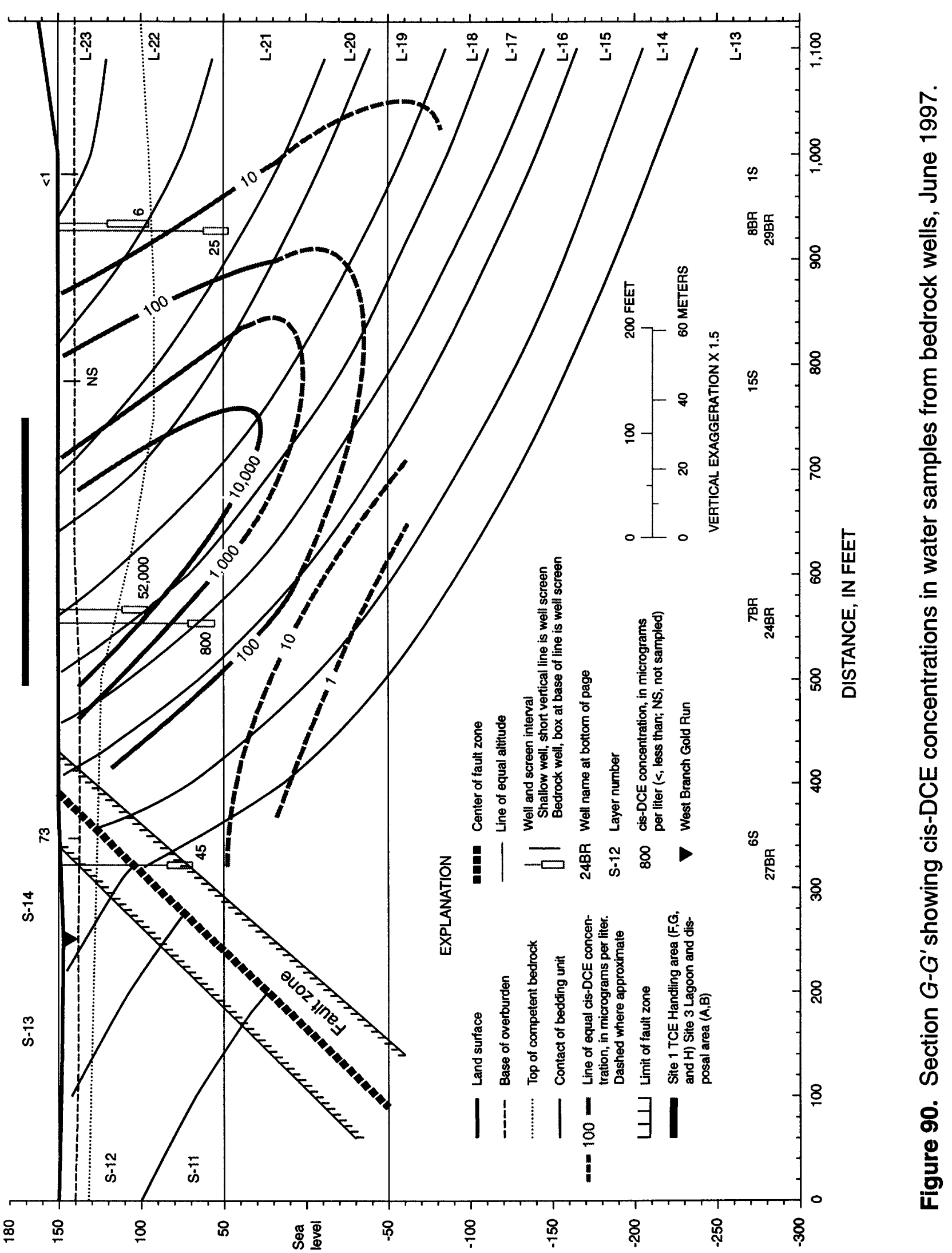




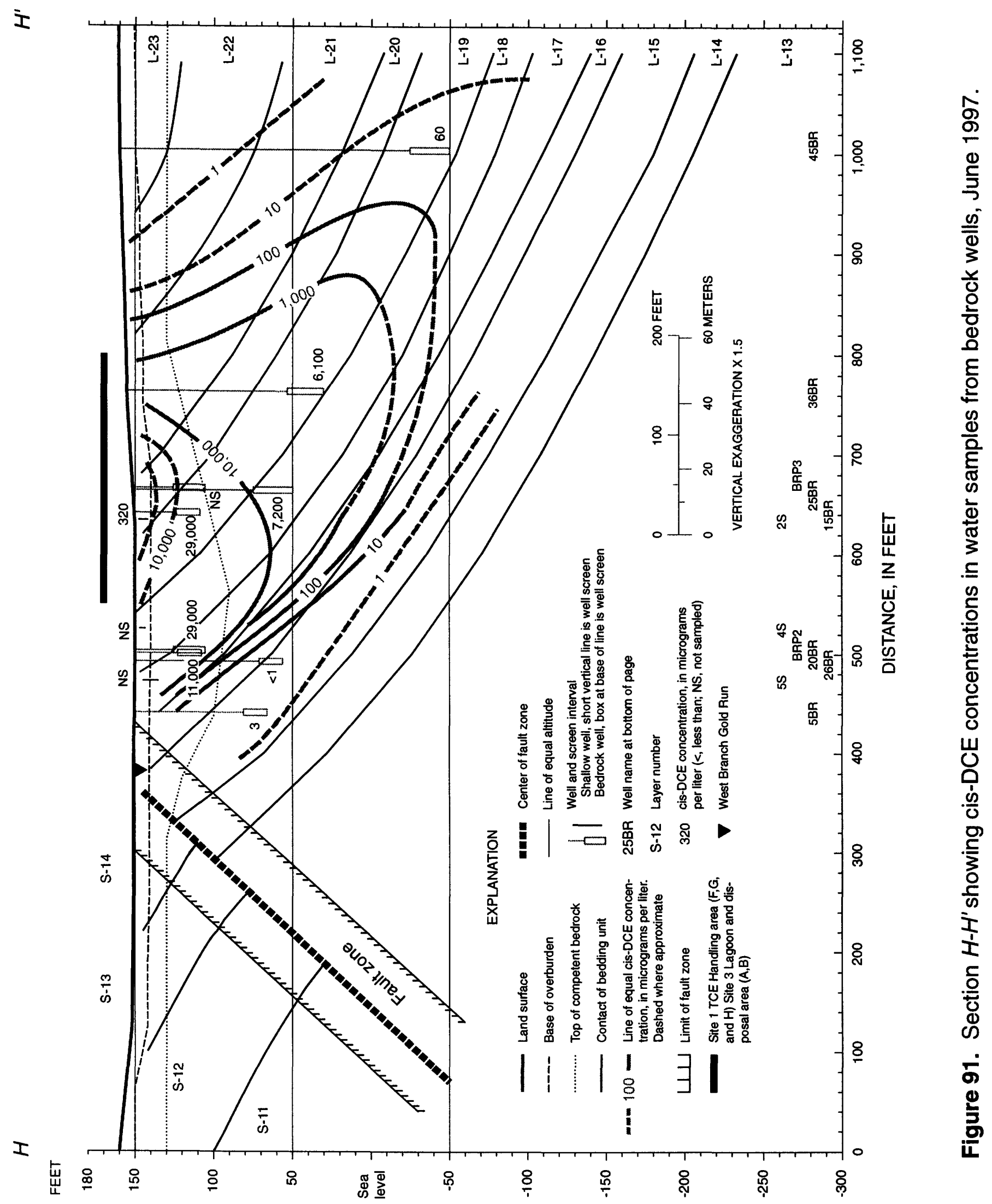




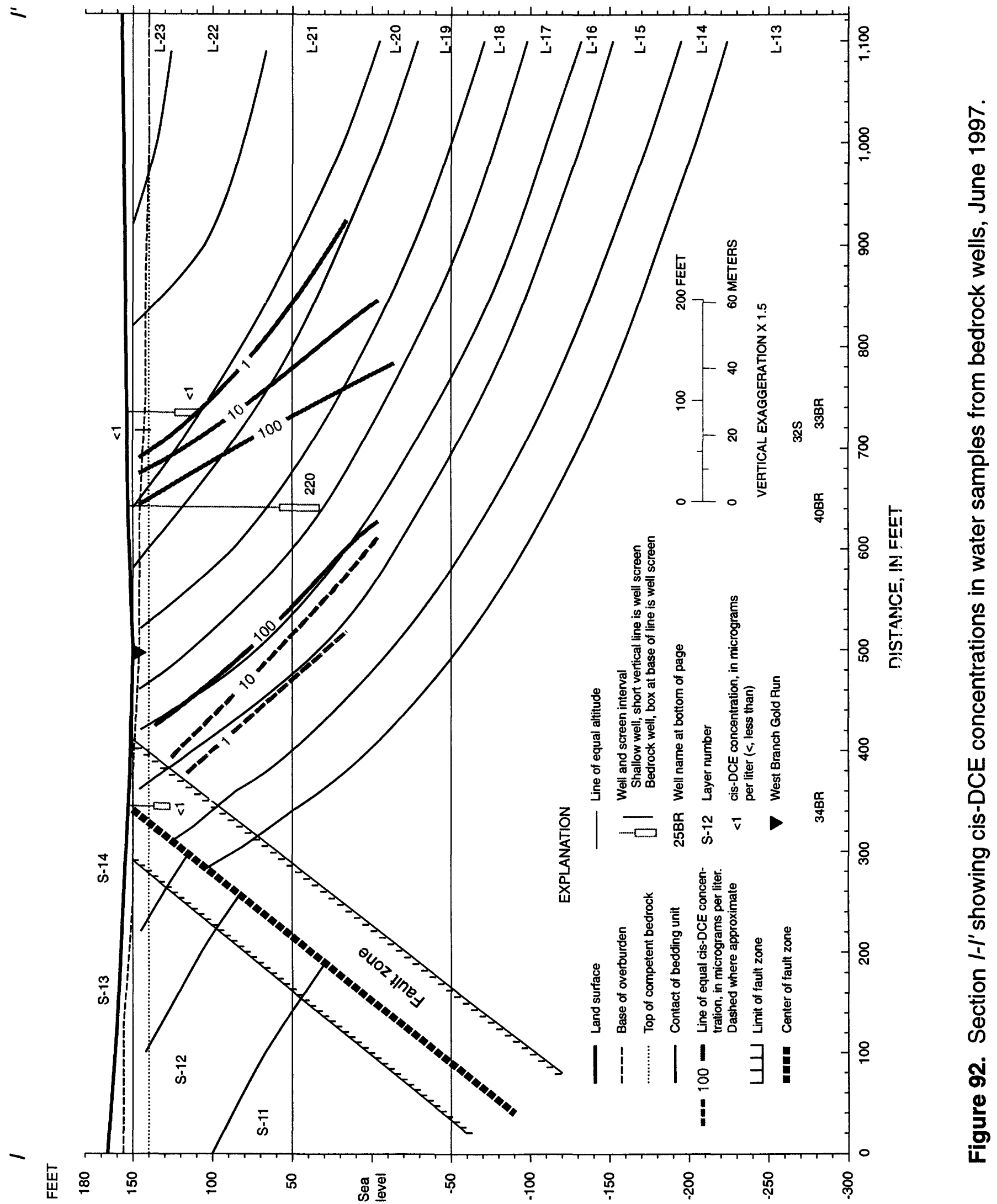


from east to west along the north side of the fault, well 31BR is downgradient from the lagoon and it shows a cis-DCE concentration of $30 \mu \mathrm{g} / \mathrm{L}$. cis-DCE concentration in well 31BR was $8 \mu \mathrm{g} / \mathrm{L}$ in 1993.

\section{Area between Site 3 and Site 1}

Concentration of cis-DCE in wells 16BR and $41 B R$ in the area between site 3 and site 1 (section D and E) were 189 and $330 \mu \mathrm{g} / \mathrm{L}$, respectively, in 1997. cis-DCE concentrations in well $16 \mathrm{BR}$ were 97 to $250 \mu \mathrm{g} / \mathrm{L}$ in three sampling events during 1993. These cis-DCE concentrations may indicate a relatively high degradation of TCE in bedding unit L-19.

\section{Site 1: Brine-Handling Area}

Concentrations of cis-DCE in the Site 1 area ranged from $<10$ to $52,000 \mu \mathrm{g} / \mathrm{L}$. Water samples from five wells show cis-DCE concentrations greater than $11,000 \mu \mathrm{g} / \mathrm{L}$ and samples from four wells showed cis-DCE concentrations that range from 1,900 to 7,200 $\mu \mathrm{g} / \mathrm{L}$ in 1997. These concentrations of cisDCE indicate that TCE is biodegrading. The center of the cis-DCE plume as defined by the $10,000-\mu \mathrm{g} / \mathrm{L}$ contour line at land surface (fig. 81 ) has migrated from the Site 1 source area (fig. 2) about $200 \mathrm{ft}$ southwestward. Ground water in the upper $100 \mathrm{ft}$ of the Lockatong aquifer is believed to discharge into the West Branch of Gold Run north of the fault. Therefore, the cis-DCE contamination dissolved in the ground water also discharges into the stream.

Three wells south of the fault in the Site 1 area were sampled in 1997 for cis-DCE. Wells $35 \mathrm{BR}$ and 28BR showed $\angle 1$ to $2 \mu \mathrm{g} / \mathrm{L}$ of cisDCE during 1992-93, 1995, and 1997. Water samples from well 22BR showed cis-DCE concentrations of $132 \mu \mathrm{g} / \mathrm{L}$ in 1997 and concentrations of 10 to $16 \mu \mathrm{g} / \mathrm{L}$ in 1995 . It is interpreted that the TCE at the site of well 22BR is being degraded to cis-DCE.

\section{Area West of Site 1}

There are insufficient data along Section I or in areas to the west of section I to confirm movement of TCE or cis-DCE onto the r'est side of the West Branch of Gold Run. Groundwater-flow direction and the movement of the cis-DCE plume is indicated by the southwestward shift of the center of the cis-DCE p'ume. Ground water moves much more slowly at depths greater than $100 \mathrm{ft}$ below land surface than at land surface, and TCE biodegrades more slowly at depths greater than $100 \mathrm{fl}$ below land surface than nearer to land surface. As a result, there is not much apparent movement of the center of the DC plume. at 100 feet below land surface (fig. 82) when compared with TCE at the same depth (f $\mathrm{g}$. 70). At a depth of $200 \mathrm{ft}$ below land surface, the cis-DCE concentrations were less than 10 $\mu \mathrm{g} / \mathrm{L}$. Therefore, there is little TCE degre dation to cis-DCE occurring at this depth.

\section{Vinyl chloride (VC)}

The U.S. Navy did not use VC as part of the routine operation at the NAWC. Ther fore, in all likelihood, all VC in ground water is a product of biodegradation of cis-DCE in reducing environments and abiotic degradation in oxidizing environments. VC concentretions are shown in maps and sections (figs. 93 to 104). In 1997, water samples from 16 of the 48 bedrock wells contained VC concentrations greater than the detection limit. Water from well 20BR showed VC concentrations of $21,000 \mu \mathrm{g} / \mathrm{L}$ and wells 15BR, 26BR, and 7BR showed $\mathrm{VC}$ concentrations that range from 3,700 to $9,200 \mu \mathrm{g} / \mathrm{L}$. Each of these four v'ells are screened within $50 \mathrm{ft}$ of land surface; therefore, the conditions for degradation of cis-DCE to $\mathrm{VC}$ are interpreted to be most favorable at shallow depths at the NAWC. Five wells had $\mathrm{VC}$ concentrations from 10 to $1,000 \mu \mathrm{g} / \mathrm{L}, 7$ wells had VC concentrations from 1 to $10 \mu \mathrm{g} / \mathrm{L}$, and $\mathrm{VC}$ was undetected in 32 wells. 


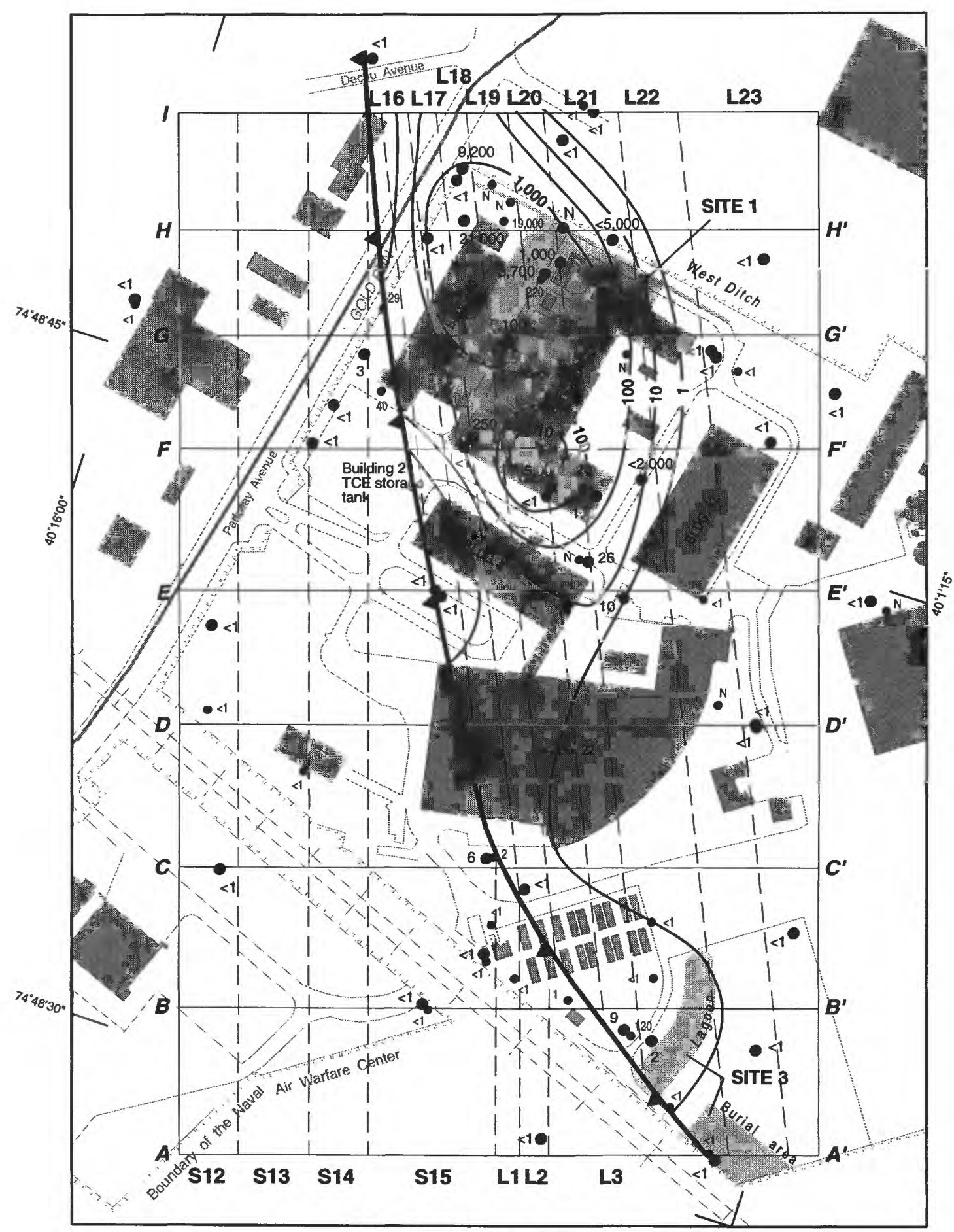

EXPLANATION

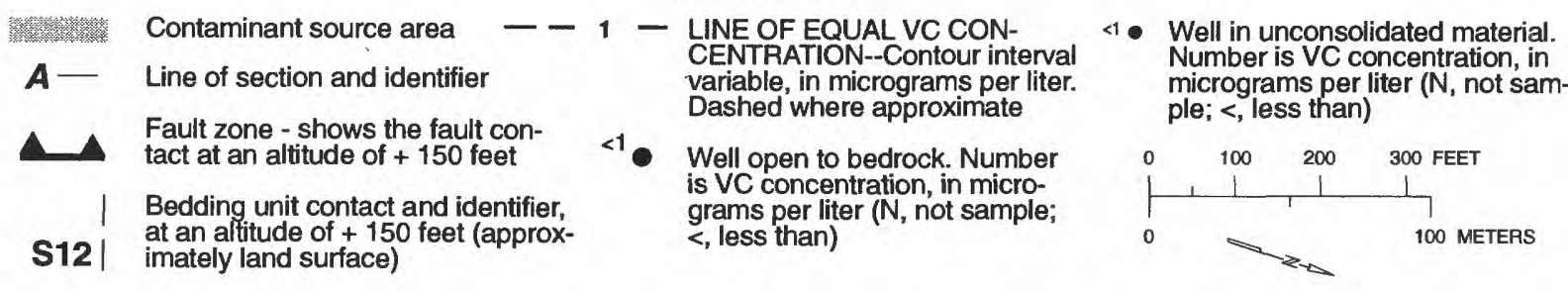

Figure 93. VC concentrations, in micrograms per liter, in water samples from bedrock and shallow wells, June 1997, and contours for top of bedrock (an altitude of +150 feet and approximately land surface), Naval Air Warfare Center, West Trenton, N.J. 

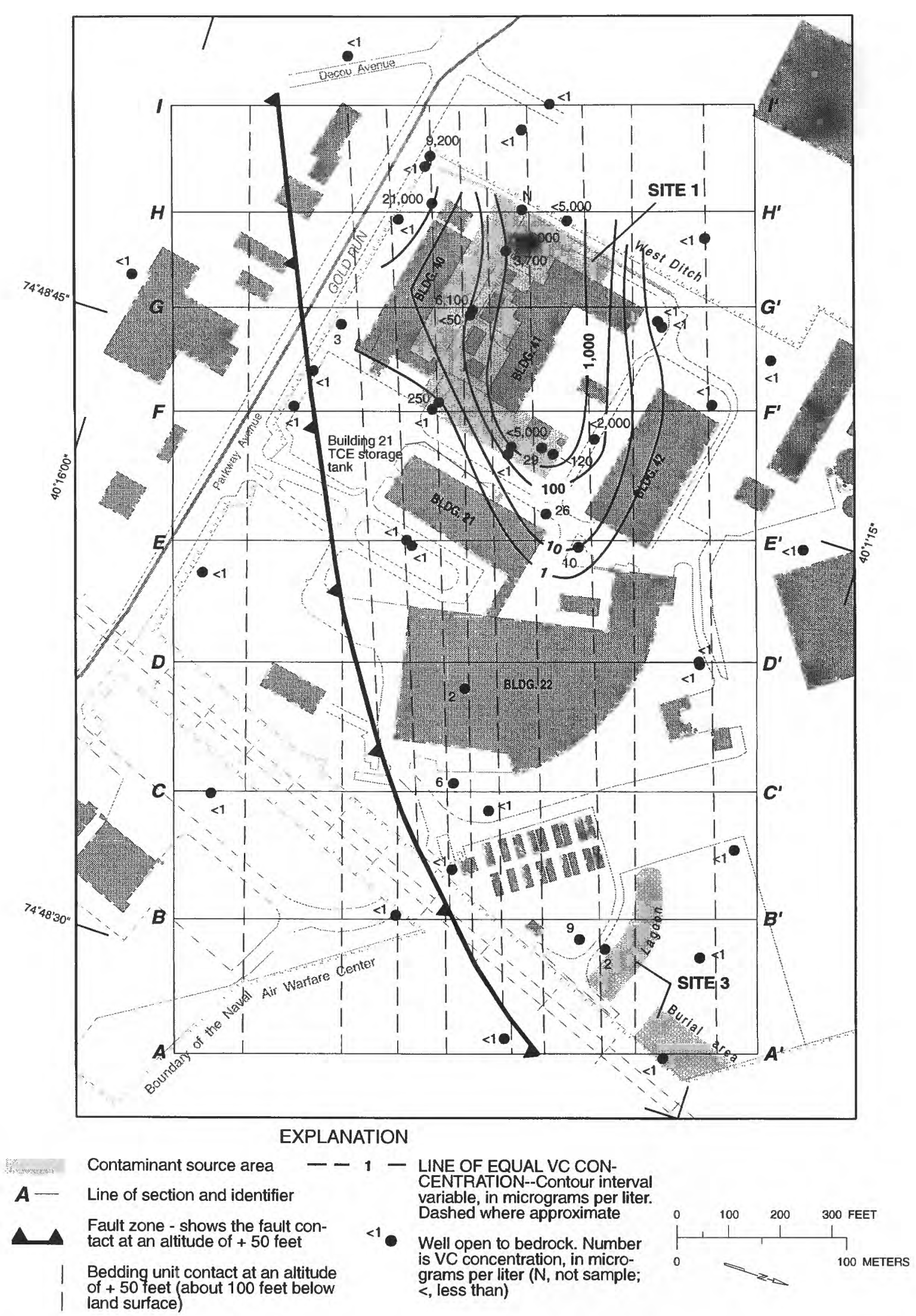

Figure 94. VC concentrations, in micrograms per liter, in water samples from bedrock, June 1997, and contours for an altitude of +50 feet (about 100 feet below land surface), Naval Air Warfare Center, West Trenton, N.J. 


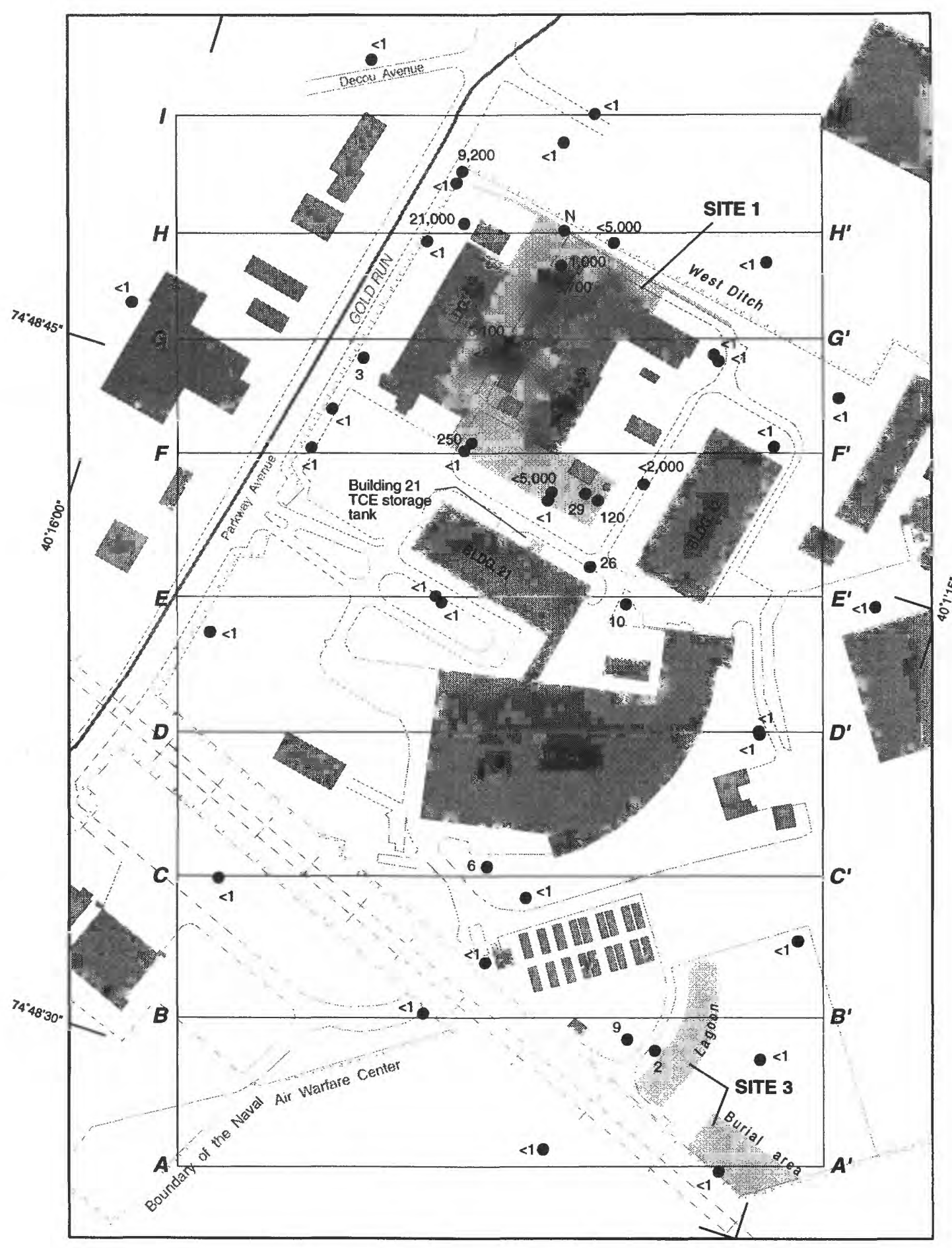

\section{EXPLANATION}

Contaminant source area

A - Line of section and identifier

$<1$ Well open to bedrock. Number

is VC concentration, in micrograms per liter ( $N$, not sampled; <, less than)

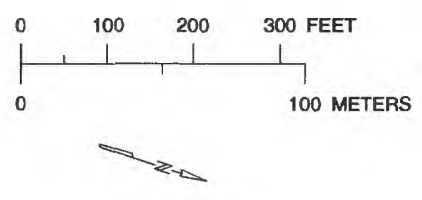

Figure 95. VC concentrations, in micrograms per liter, in water samples from bedrock wells, June 1997, and contours for an altitude of - 50 feet (about 200 feet below land surface), Naval Air Warfare Center, West Trenton, N.J. 
-

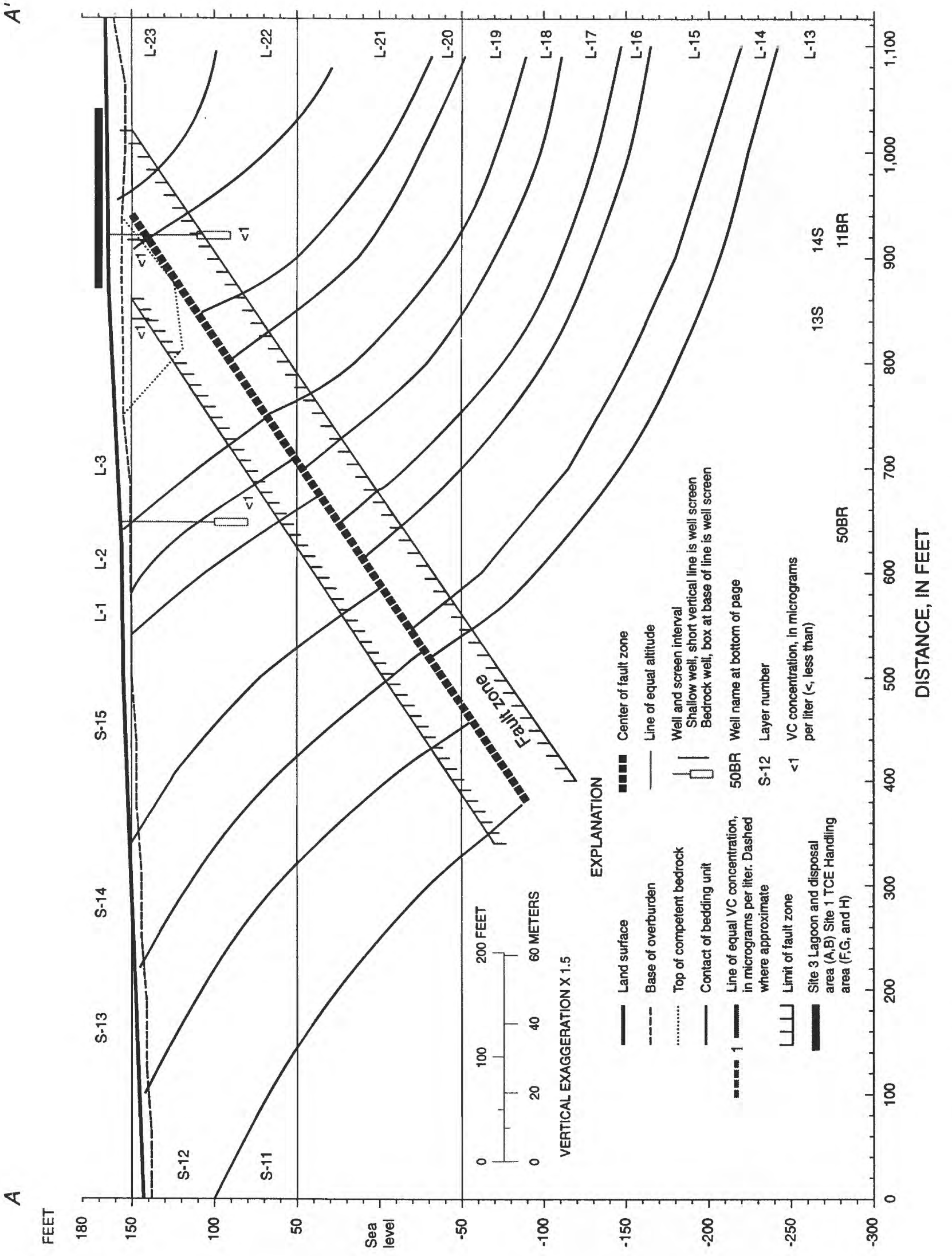

ลิ

兵

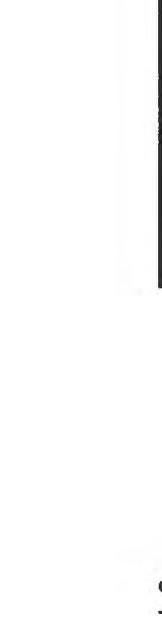

2

$\varangle$

㐫

돈

듬

ํㅡㅇ

흥

$\varepsilon$

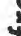

.

है

㐫

.든



$\checkmark$

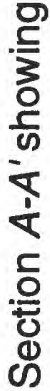

ष्ठ 
in

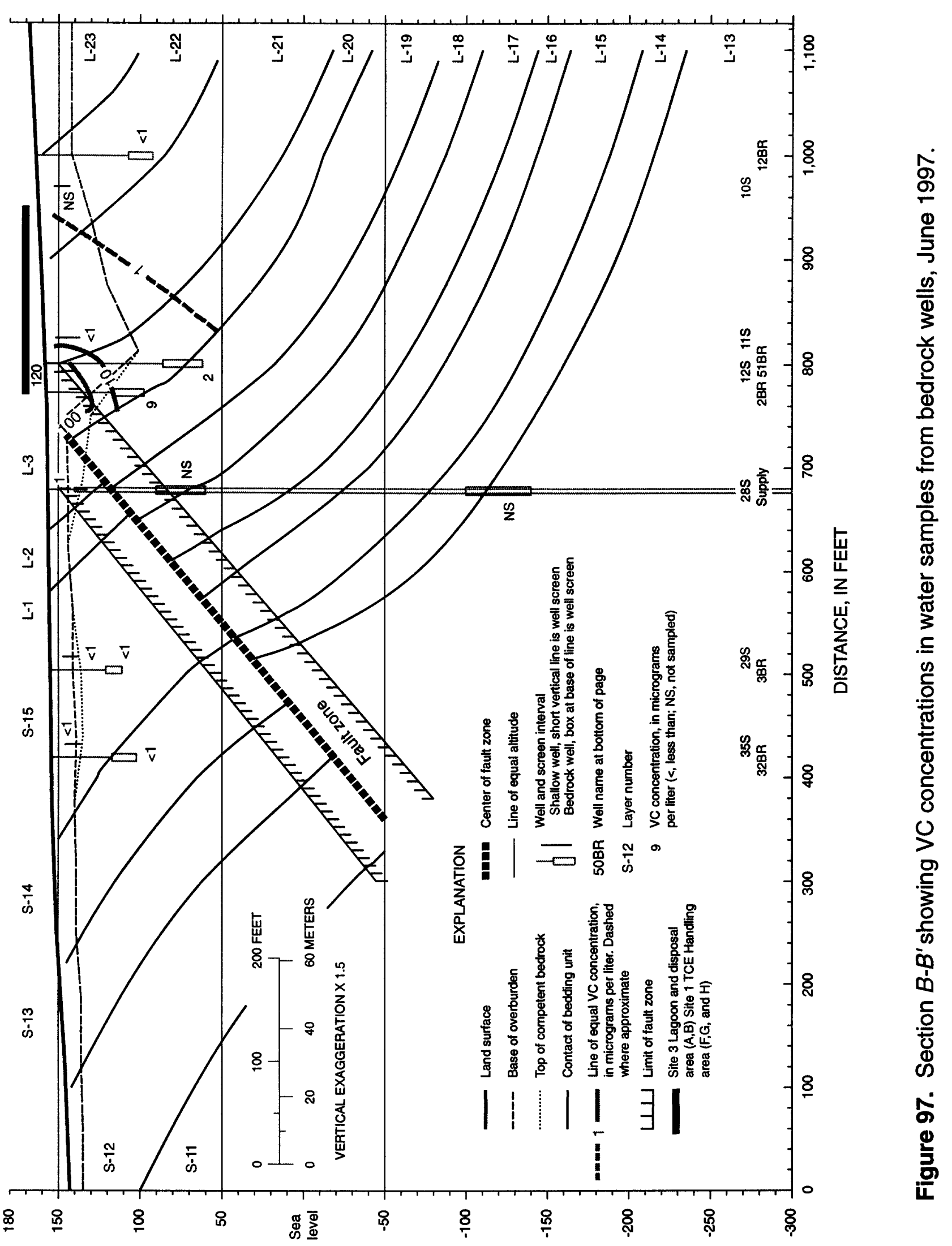


ì

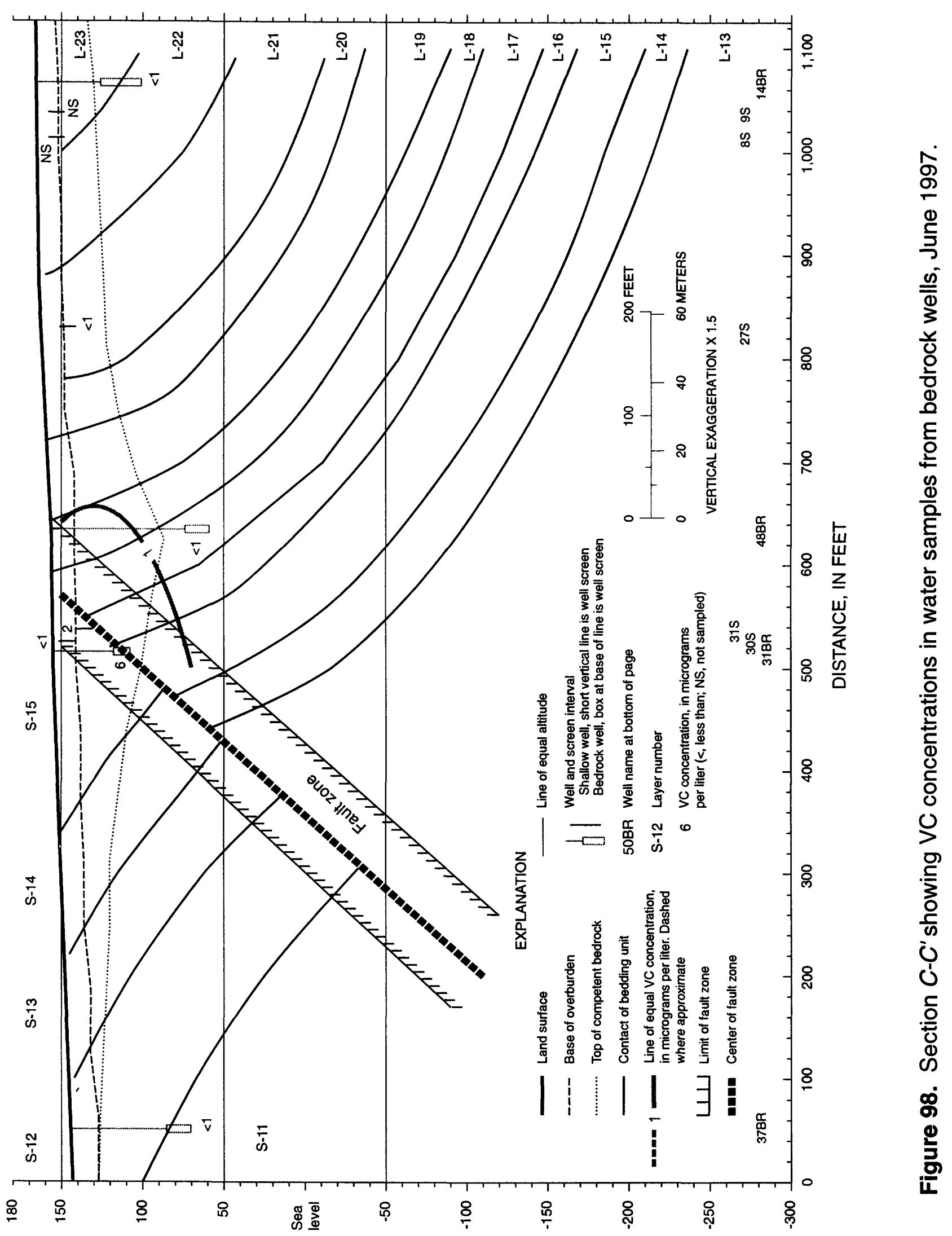


a

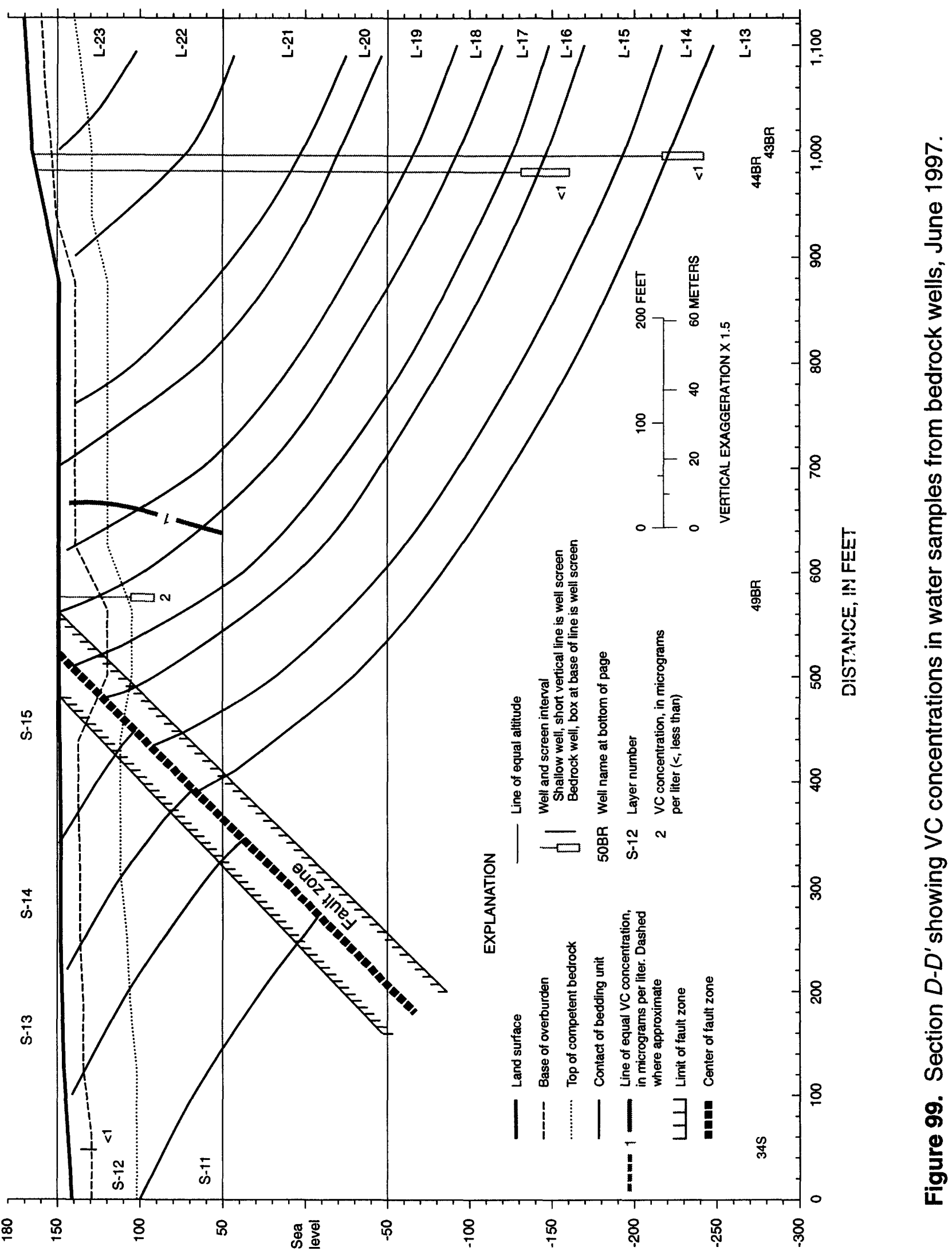


ü

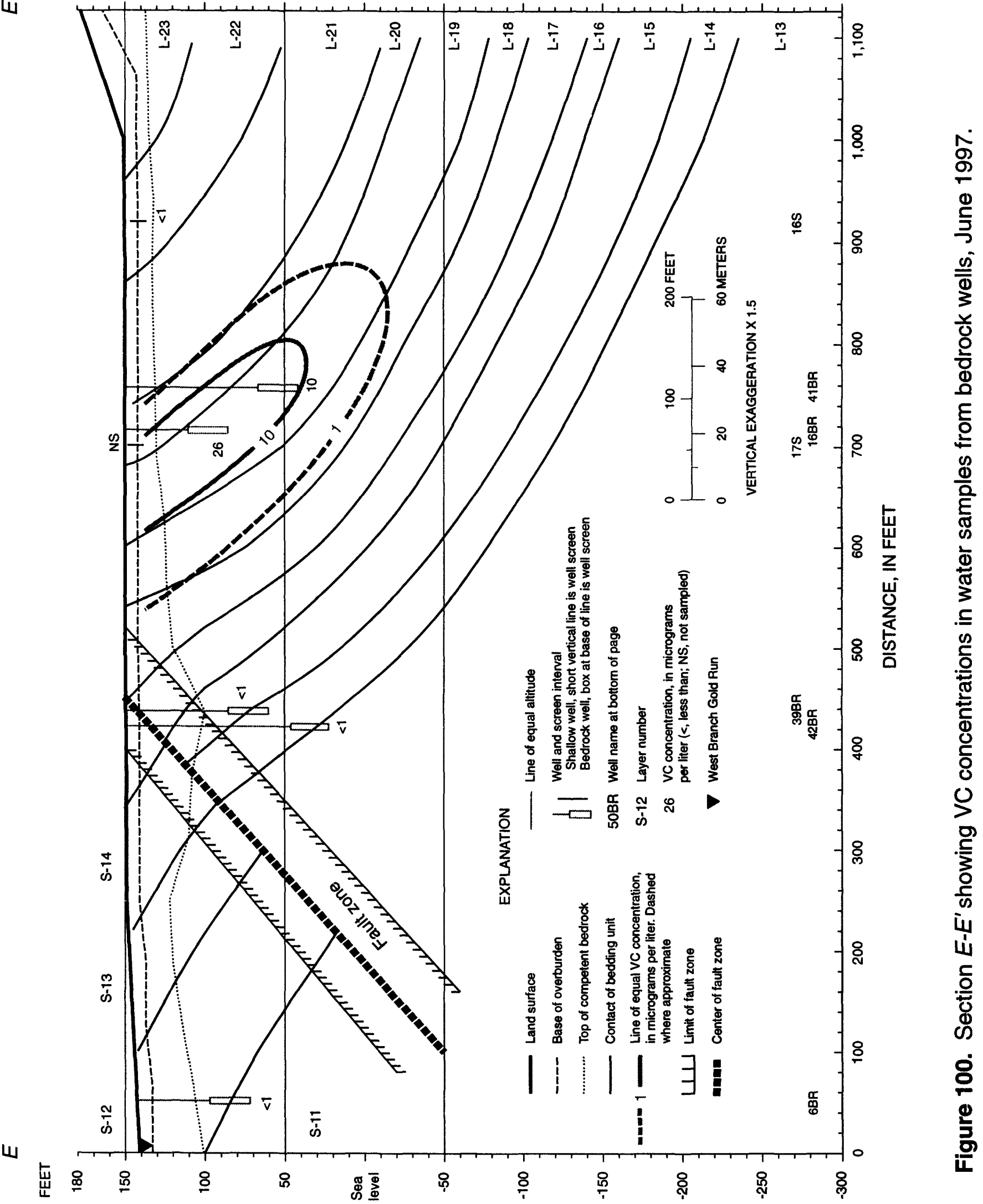




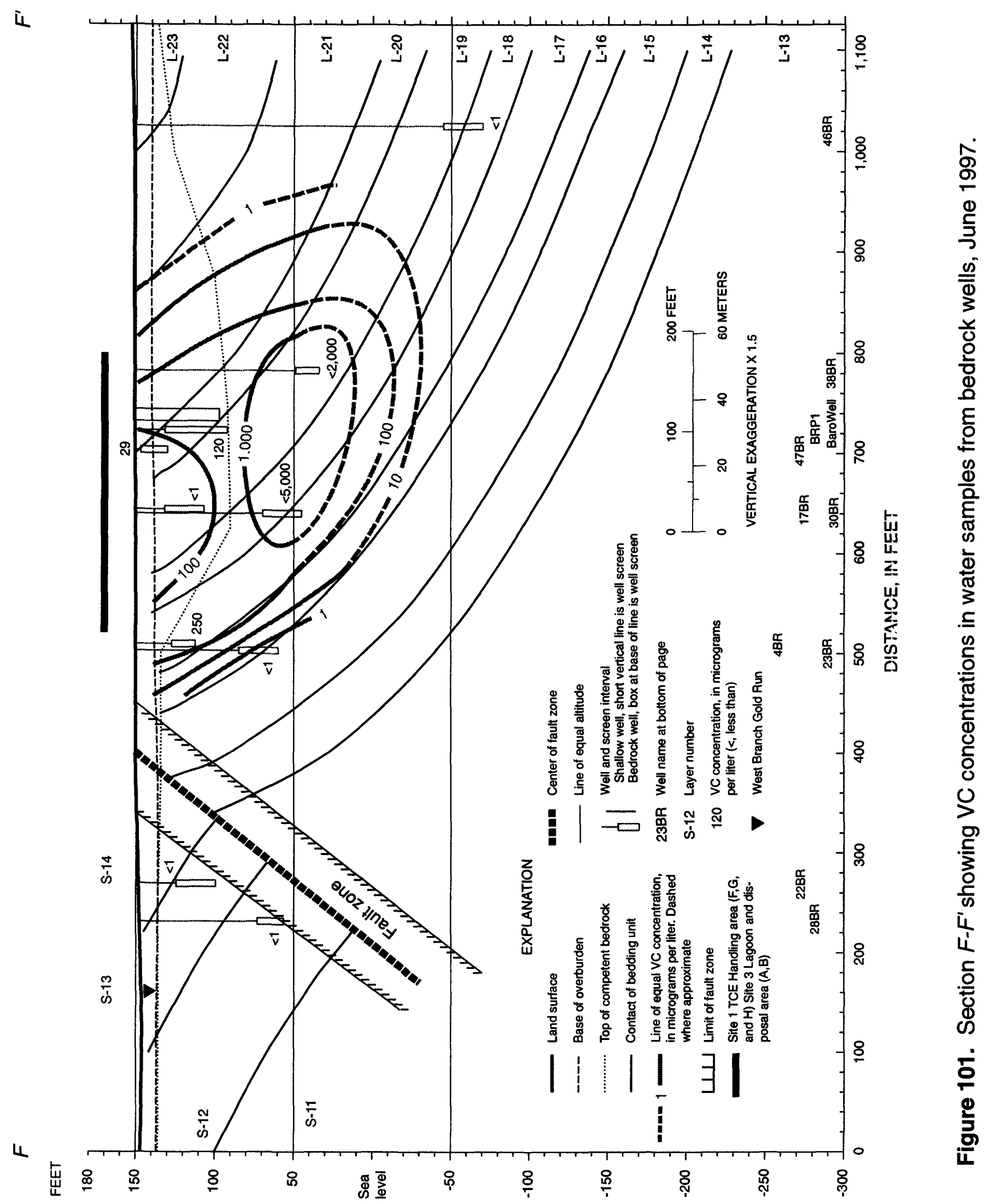


i

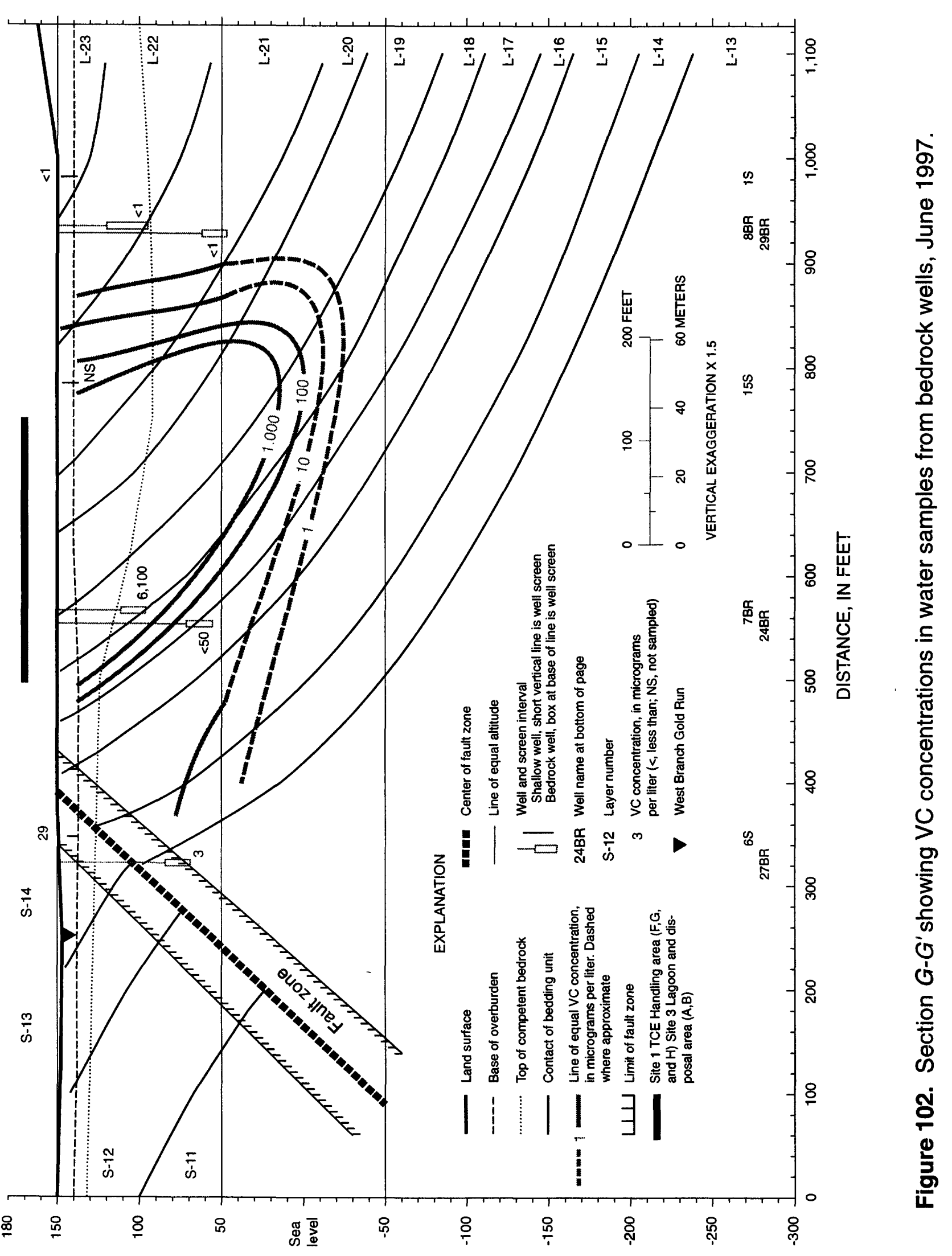


I

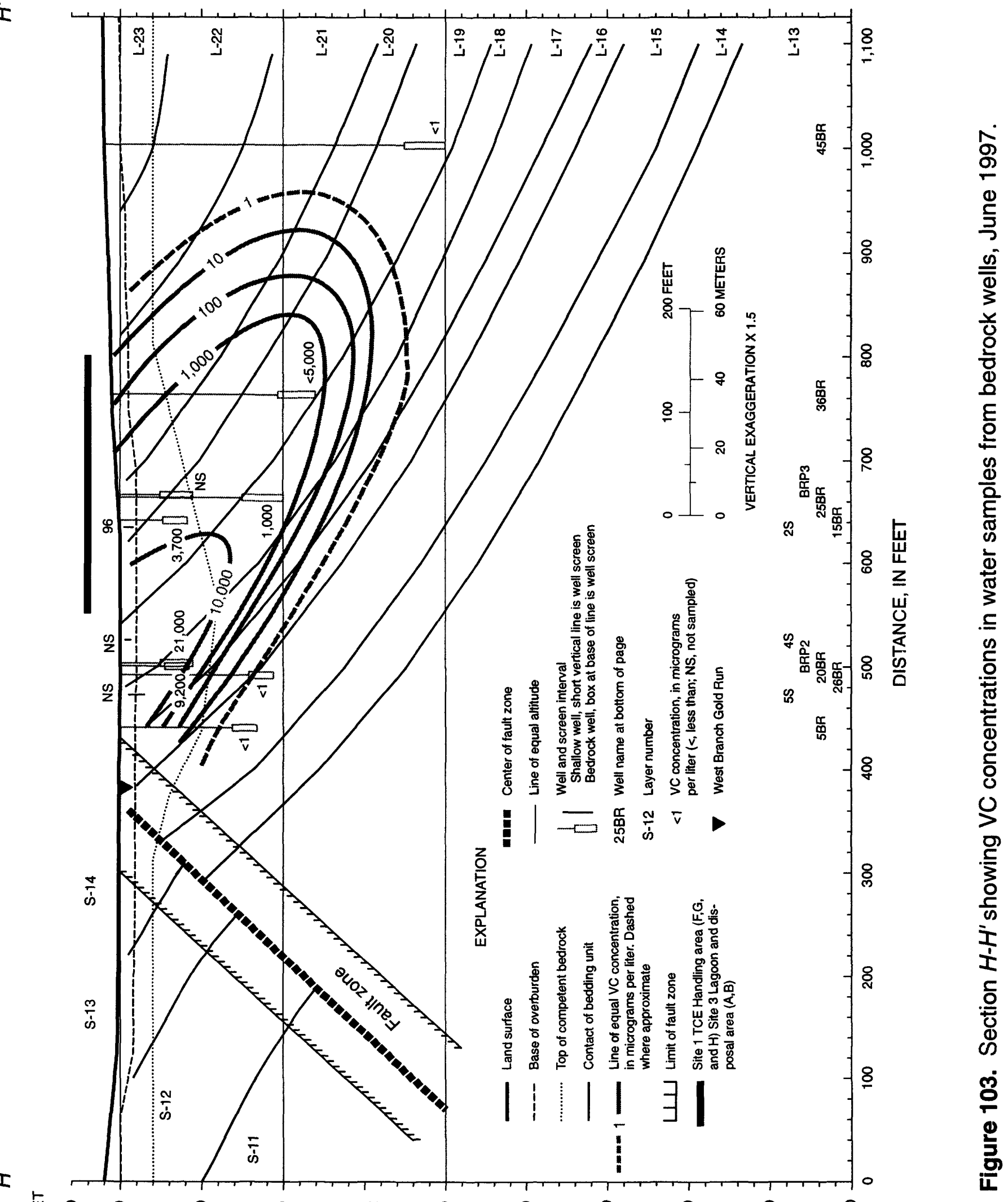




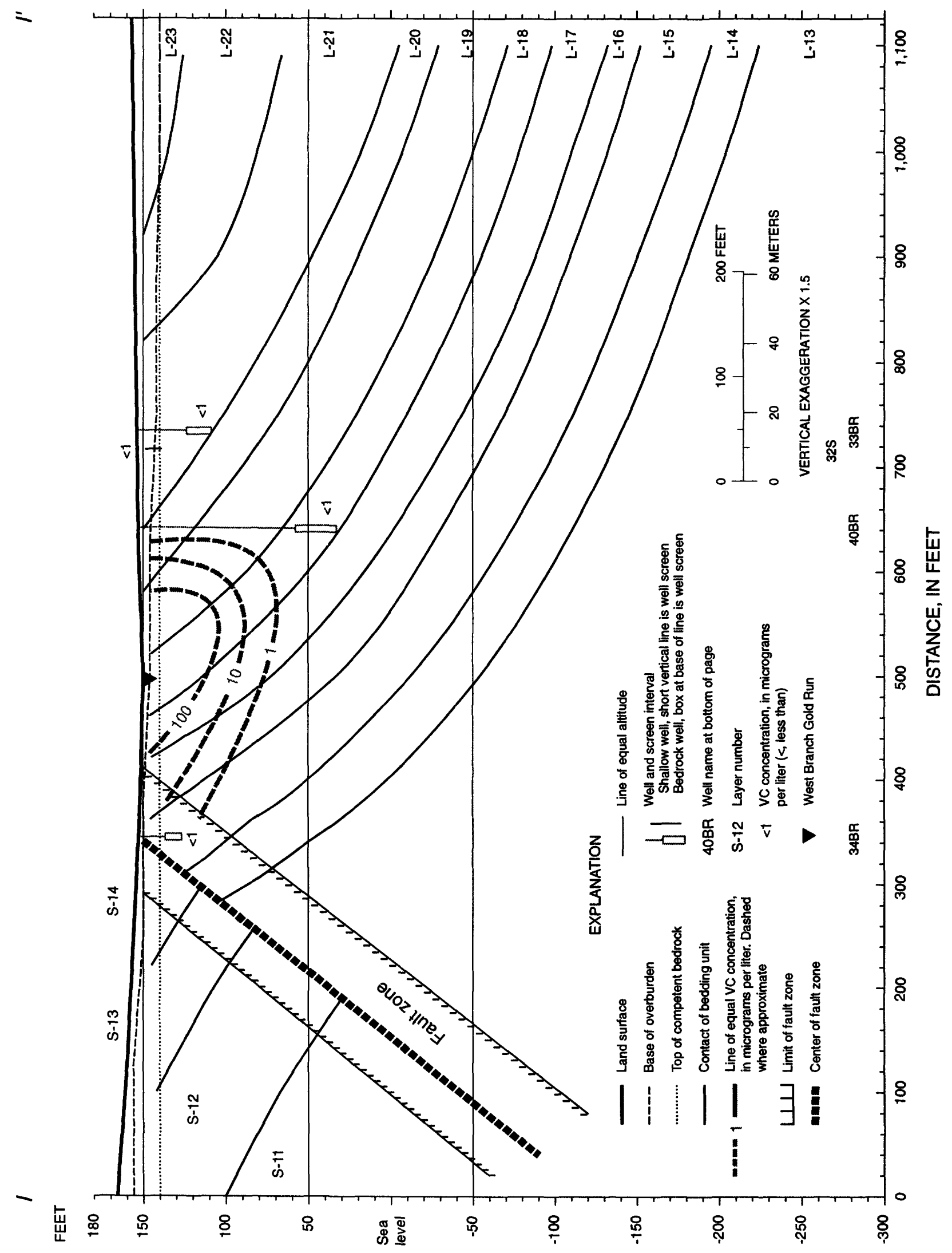

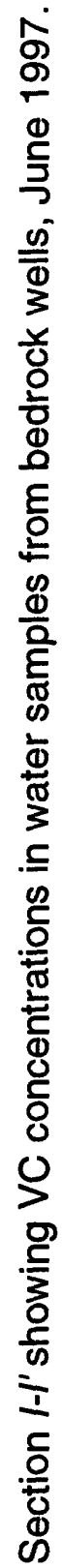

웅 
Site 3: Lagoon and Sludge Disposal Area

Concentrations in the VC plume in the Site 3 area were less than $7 \mu \mathrm{g} / \mathrm{L}$ in 1997. The plume is limited to the area directly below the former lagoon. The VC plume does not appear to have moved down gradient to the southwest nor was it detected under the sludge disposal area.

\section{Area between Site 3 and Site 1}

North of the Building 21 area, the concentrations of VC in wells 16BR and 41BR were 26 and $10 \mu \mathrm{g} / \mathrm{L}$ respectively. VC concentrations in well 16BR were 12 to $62 \mu \mathrm{g} / \mathrm{L}$ in three sampling events during 1993, and well 41BR was not sampled before. These concentrations indicate some degradation of cis-DCE to VC in bedding unit L-19.

\section{Site 1: Brine-Handling Area}

The maximum concentration of $\mathrm{VC}$ in the Site 1 area was $21,000 \mu \mathrm{g} / \mathrm{L}$ in well BRP2 in 1997. Wells 20BR showed VC concentrations of $9,100 \mu \mathrm{g} / \mathrm{L}$. The wells are screened in bedding unit L-17. The center of the VC plume at land surface (fig. 93) is about 200 to $300 \mathrm{ft}$ west of the center of the TCE plume (fig. 69) and about $100 \mathrm{ft}$ west of the center of the cisDCE plume (fig 81). The VC plume is interpreted to be moving southwestward with ground-water flow toward the West Branch of Gold Run.

Well 4BR showed a VC concentration of $250 \mu \mathrm{g} / \mathrm{L}$ in 1997 . The well also is screened in bedding unit L-17. Wells BRP1, 16BR, and 41BR form a northeast limb of the Site $1 \mathrm{VC}$ contamination area. Well BRP1 is in bedding units L-19 and L-20, whereas wells 16BR and 41BR are in bedding units L-19. This arm of the Site I VC plume is interpreted to be controlled by some aspect of the bedding units, but it is not understood which aspect of degradation and ground-water flow is controlling the higher concentrations of VC in this bedding.
There is very little concentration of $\mathrm{VC}$ at depth (fig. 95); therefore, the conditions are not optimal for degradation at depth. There is no reported VC south of the fault in 1997. Water samples collected during 1992-93 and 1995 also showed VC concentrations below detection limits.

\section{SUMMARY AND CONCLUSION}

The hydrogeologic framework was evaluated and water-level and water-quality data were analyzed as part of an investigation of trichloroethylene (TCE) contamination of ground water at two sites at the Naval Air Warfare Center (NAWC) in West Trentor, N.J.

The hydrogeologic framework consists of upper strata of the Stockton Formation ard the lower strata of the Lockatong Formation with an east/west-trending fault. The Stockton Formation has been divided into 5 bedding units and the Lockatong Formation has boen divided into 14 bedding units. The bedding units are based on the signature of gamma-ray logs, rock type, and rock color. The strike of the bedding units of the Stockton Formation and the Lockatong Formation are $\mathrm{N} 70^{\circ} \mathrm{E}$ and $\mathrm{N} 65^{\circ} \mathrm{E}$, respectively. The general dip of each formation is about $15^{\circ}$ to $30^{\circ} \mathrm{NW}$ in areas that are more than $300 \mathrm{ft}$ from the fault. Close to the fault the bedrock dip increases to $70^{\circ} \mathrm{NW}$. The Stockton Formation is the Stockton aquifer; the Lockatong Formation is the Lockatong aquifer. The Stockton and Lockatong aquifers are made up of a number of water-bearing zones and semi-confinirs zones.

The east/west-trending fault has been mapped (prior to the investigation reported here) as a gradational contact between the Stockton and the Lockatong Formations. The fault strikes roughly $\mathrm{N} 70^{\circ} \mathrm{E}$, similar to the strike of the bedrock, and dips about $40^{\circ} \mathrm{SE}$. The fault separates the two formations-- the 
Lockatong predominantly to the north, and the Stockton predominantly to the south-- and acts as a confining unit.

Static water-level maps at land surface show an apparent regional hydraulic gradient to the south. Because actual ground-water flow is within the bedding-plane partings and nearvertical partings in the bedrock, however, the true flow direction on the north side of the fault is westward toward the West Branch of Gold Run and the Delaware River. The flow direction on the south side of the fault is toward the West Branch of Gold Run. The fault inhibits the direct flow of water from the Lockatong aquifer into the Stockton aquifer. Ground water from the Lockatong aquifer discharges into the West Branch of Gold Run in a spring west of NAWC and flows overland to the Stockton aquifer.

Water-level drawdowns that resulted from aquifer tests in the Lockatong aquifer show elongate cones of depression around pumped wells; therefore, the aquifer is anisotropic. Water levels in selected water-bearing zones of the aquifer shows circular or near circular cones of depression around the pumped wells; therefore, these water-bearing zones are isotropic or nearly so. The drawdown water-levels maps and sections show that water withdrawal from one bedding unit will cause drawdown most readily in wells screened in the same unit. The same maps and sections show that the shallower part of the bedding units is probably more fractured but less permeable than the deeper part of the bedding unit. Stressed water levels, as a result of operation of the recovery well created an elongate cone of depression, but the cone does not encompass the whole TCE contamination plume of the brine handling area (Site 1).
Water-quality data from Lockatong aquifer shows that TCE flowed from the. source areas downward. In the lagoon and sludge-disposal area (Site 3), the dissolved TCE flowed from the area in a southwestward direction along the north side of the fault. In the Site 1 area, dense non-aqueous phase liquid (DNAPL) trichloroethylene (TCE) flowed downward into the bedrock aquifer; however, DNPAL TCE has not been found in water samples from the aquifer. Two possible scenarios for the fate of the DNAPL TCE are (Scenario 1) that the DNAPL TCE sank to a depth of about $300 \mathrm{ft}$ below land surface or (scenario 2) that the DNAPL TCE disso'ved and degraded by a depth of $100 \mathrm{ft}$ below land surface. In Scenario 1, the plume of DNAPL TCE is not deeper than about $300 \mathrm{ft}$ below land surface because the partings are closed at those depths. The DNAPL TCE at depth dissolves very slowly because there is very limiteground-water flow. Data show there are very little cis 1,2-dichloroethylene (cis-DCE) and vinyl chloride (VC) at depth when compared to the shallow aquifer; therefore, there is little degradation of the dissolved TCE at derth.

cis-DCE and VC were not used during routine operation at NAWC, and cis-DCE and $\mathrm{VC}$ in the aquifer is a result of degradat $2 n$ of TCE. High levels of cis-DCE and VC ir the shallow part of the aquifers indicate that degradation of TCE is occurring there, wherens low levels of cis-DCE and VC in the deep part of the aquifer indicates that little degradation is occurring there. The center of the cis-DCE and VC plumes are about 100 and $200 \mathrm{ft}$, respectively, west of the center of the TCE plume. This indicates that ground-water-flow direction is westward toward the West $\mathrm{E}$ "anch of Gold Run. 


\section{REFERENCES CITED}

Chappell F. H., 1993, Ground-water microbiology and geochemistry: New York, John Wiley \& Sons, Inc., 424 p.

EA Engineering, Science, and Technology, Inc., 1995, Site 1 Interim action well monitoring at Naval Air Warfare Center, New Jersey. Reports 1, 2, 3, and 4: Berkeley Heights, N.J., EA Engineering, Science, and Technology, Inc., about 100 pages.

February 1996, Site 1 Interim action well monitoring at Naval Air Warfare Center Trenton, New Jersey; Report 5: Berkeley Heights, N.J., EA Engineering, Science, and Technology, Inc., about 100 pages.

June 1996, Draft Site 1 Focused Feasibility Study Site Safety, Health, and Emergency Response Plan for the Naval Air Warfare Center Trenton, New Jersey: Berkeley Heights, N.J., EA Engineering, Science, and Technology, Inc., about 100 pages.

July 1996, Final 1995 Aquifer test report for Naval Air Warfare Center Trenton, New Jersey: Berkeley Heights, N.J., EA Engineering, Science, and Technology, Inc., about 100 pages.

August 1997, Ground water sampling report NAWC Trenton (Ewing Township), New Jersey: Berkeley Heights, N.J., EA Engineering, Science, and Technology, Inc., about 100 pages.
International Technology Corporation, November 1994, Remedial Investigation Report, Installation Restoration Prc જुram, Naval Air Warfare Center Trenton, New Jersey: Edison, N.J., International Technology Corp., contract N624-86-c1041 IT project Number 529538, 529658, 6 volumes.

Lyttle, P.T., and Epstein, J.B., 1987, Genlogic map of the Newark $1^{\circ} \times 2^{\circ}$ quadran New Jersey, Pennsylvania and New York: U.S. Geological Survey Miscellane ous Investigations Series Map I-1715, 2 sheets.

Mercer County Highway Department, 1942, Parkway Avenue construction map, File A, Pocket 14, Folder 1 to 3 unpublished maps, available at County building, East State St., Trenton, N.J.

New Jersey Department of Environmental Protection, 1913, New Jersey Atlas Sheet 27 , Original Survey 1885, principle features revised 1913: Trenton, N.J., New Jersey Department of Environmental Protection, 1 sheet.

Vecchioli, John, and Palmer, M.M., 1962, Ground-water resources of Mercer County, New Jersey: New Jersey Department of Conservation and Economic Development Special Renort $19,71 \mathrm{p}$.

U.S. Geological Survey, 1979, Aeroradioactivity map of parts of Delaware and New Jersey: U.S. Geological Survey Open-File Report 79-1683, 2 sheets. 